DEPARTMENT OF THE INTERIOR

UNITED STATES GEOLOGICAL SURVEY

CHARLES D. WALCOTT, DIRECTOR

\title{
BOUNDARIES
}

OF

\section{THE UNITED STATES}

AND OF THE

SEVERAL STATES AND TERRITORIES

WITH AN OUTLINE OF THE

HISTORY OF ALL IMPORTANT CHANGES OF TERRITORY

(THIRD EDITION)

BY

HENRY GANNETT

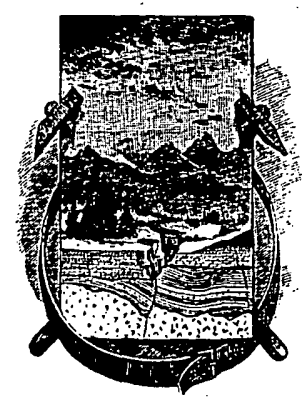

W A SHI.N G TON

GOVERNMENT PRINTING OFIICE

1904 
$G . S$

QE 25

B9
no.226-22\% 


\section{CONTENTS.}

Page.

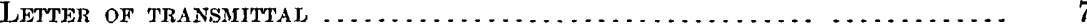

Chap'ter I.-Boundaries of the United States, and additions to its territory .. $\quad 9$

Boundaries of the United States. .......................... 9

Provisional treaty. with Great Britain..................... 9

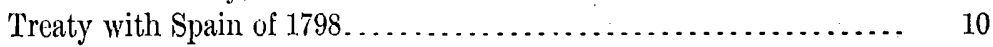

Definitive treaty with Great Britain . . . . . . . . . . . . . . . . . . 10

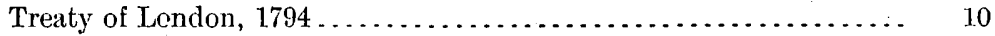

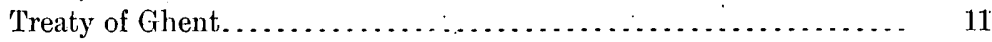

Arbitration by King of the Netherlands. . . . . . . . . . . . . . . . . 16

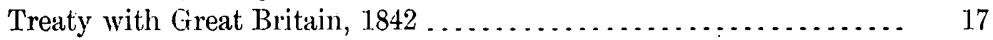

Webster-Ashburton treaty with Great Britain, $1846 \ldots \ldots \ldots \ldots \ldots . .19$

Additions to the territory of the United States . . . . . . . . . . . . . . . . . . 19

Louisiana purchase ...................................... $\quad 19$

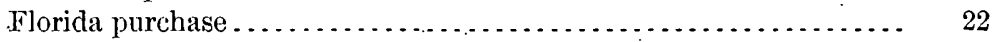

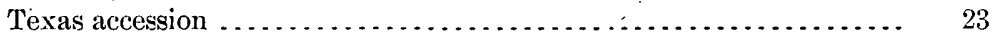

First Mexican cession................................. 23

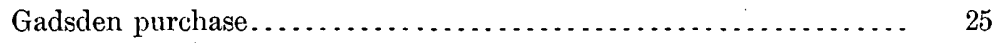

Alaska purchase ...................................... 25

Hawaiian Islands ..................................... 28

Porto Rico, Guam, and Philippine Islands ................ 28

Tutuila ............................................. 29

Crapter II.-The public domain, and an outline of the history of changes

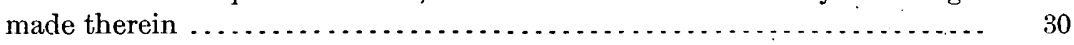

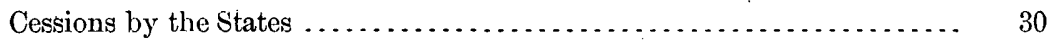

Territory northwest of the river Ohio . . . . . . . . . . . . . . . . . . .

Territory south of the river Ohio ............................. 35

Louisiana and the territory acquired from Mexico ................ 36

Chapter III.-The boundary lines of the States and Territories ........... 39

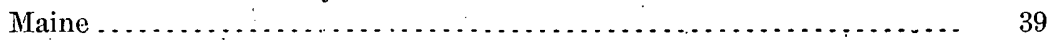

New Hampshire......................................... 47

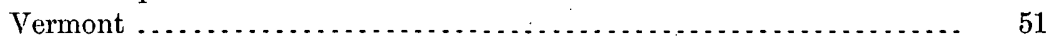

Massachusetts......................................................... 54

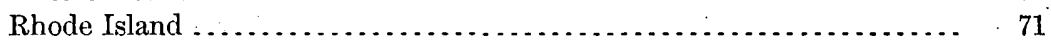

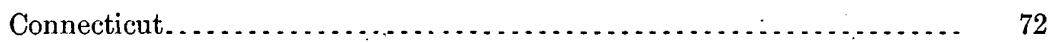

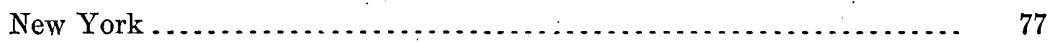

New Jersey . . . .

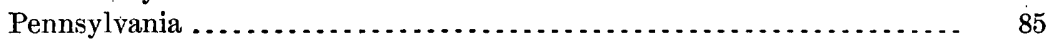

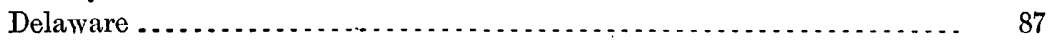

Maryland .................................................... 89

District of Columbia......................................... 92

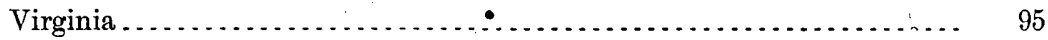

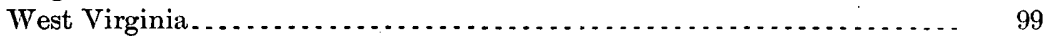


Chaprer JII.-The boundary lines of the States and Territories-Cont'd. Page. North Carolina...................................... 99

South Carolina.......................................... 103

Georgia.................................................. 104

Florida . . . . . . . 108

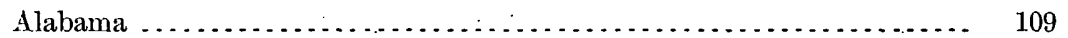

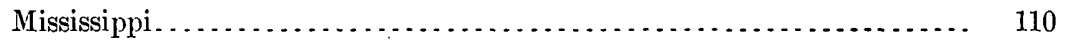

Louisiana .................................................. 111

Texas ...................................................... 112

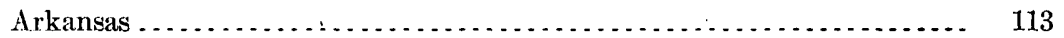

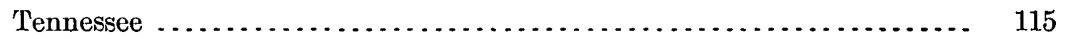

Kentucky ............................................. 117

Ohio ...................................................... 117

Tridiana.................................................... 119

Illinois . . . . . . . . . . . . . . . . . . . . . . . . . . . . . . . . . . . 120

Michigan ................................................ 120

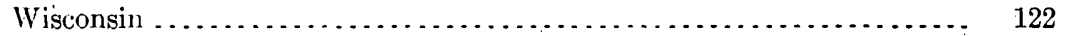

Missouri ............................................... 123

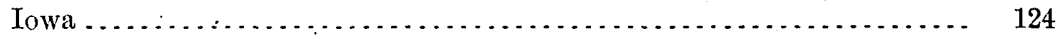

Minnesota ............................................... 125

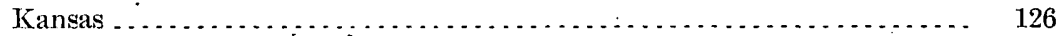

Nebraska............................................ 127

North Dakota and South Dakota ............................ 129

Oklahoma . . . . . . . . . . . . . . . . . ....................... 130

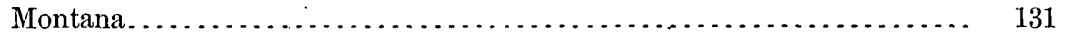

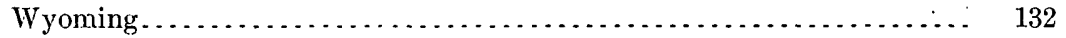

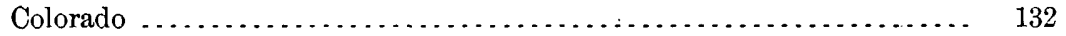

New Mexico .......................................... 133

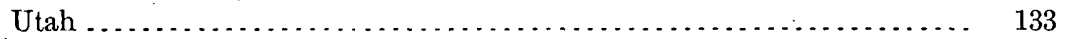

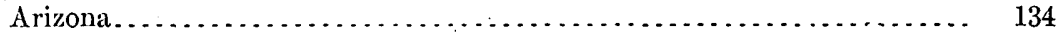

Nevada.............................................. 135

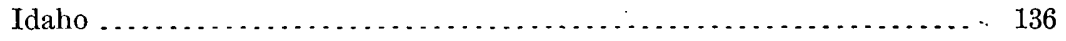

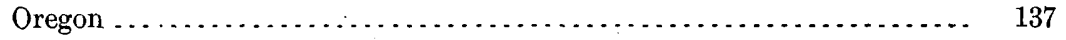

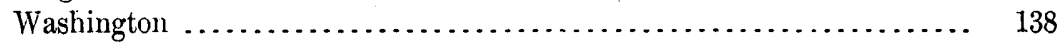

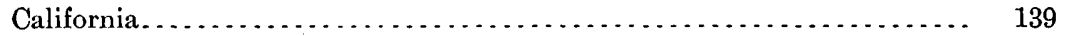




\section{L L U S T R A T I O N S.}

Plate I, II. Boundary between New York and Canada in St. Lawrence River.............

III. Boundary between New York and Canada in Niagara

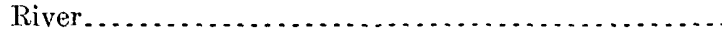

IV. Boundary between United States and Canada in St. Clair

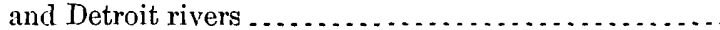

V, VI. Boundary between Michigan and Canara through St.

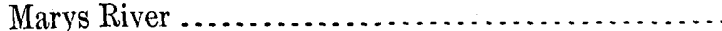

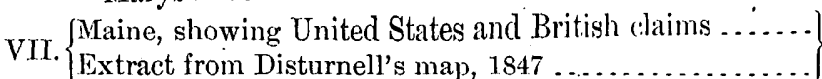

Page.

VIII-XII. Boundary between Maine and Canada .................

XIII. Boundary between Maine, New Hampshire, and Canada.

XIV. Map of the United States, showing accessions of ter ritory .

$\mathrm{XV}$. Boundary line between southeastern Alaska and Canada, as fixed by award of Alaska Boundary tribunal, October 20,1903

XVI, XVII. Boundary between Vermont and New York ...........

XVIII, XIX. North boundary of Massachusetts ...................

XX. Boundary between Massachusetts and Rhode Island .....

XXI. Boundary between Massachusetts and Connecticut ......

XXII. Boundary between Rhode Island and Connecticut.......

XXIII. Boundary between Connecticut and New York.........

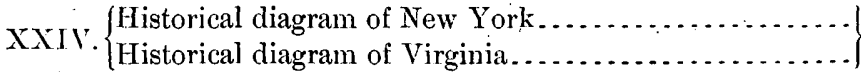

XXY. Western and southern boundary of New York...........

XXVI. Northeast boundary of New Jersey ...................

XXVII-XXXI. Boundary between Virginia and West Virginia. . . . . . . .

XXXII, XXXIII. Boundary between Virginia and Kentucky............

XXXIV. Boundary between Virginia, Tennessee, and North Carolina

XXXV-XXXVII. Boundary between North Carolina and Tennessee ...... 102

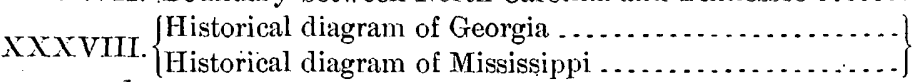

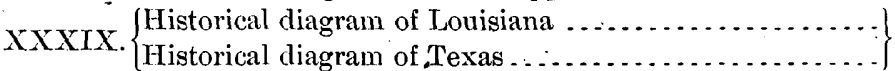

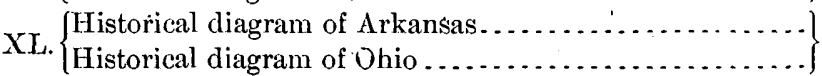

XLI-XLIII. Boundary between Kentucky and Tennessee .......... 116

XLIV. Historical diagram of Indiana.................... 118

XLV. Historical diagram of Illinois ................. 120

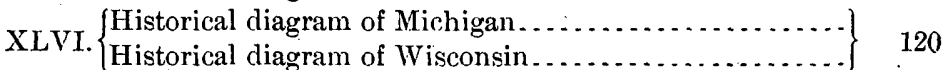

XLVIr. Historical diagram of Missouri .................... 122

XLVIII. $\left\{\begin{array}{l}\text { Historical diagram of Minnesota } \ldots \ldots \ldots \ldots \ldots \ldots \ldots \\ \text { Historical diagram of Iowa } \ldots \ldots \ldots \ldots \ldots\end{array}\right\}$ 
Page.

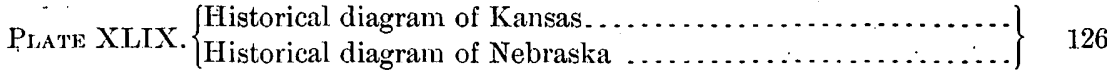

L. $\{$ Historical diagram of North Dakota and South Dakota ....... $\} 128$

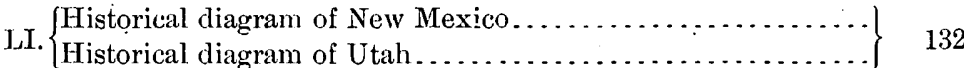

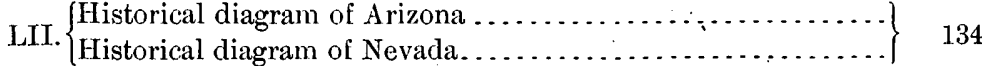

LIII. Historical diagram of Idaho....................... 136

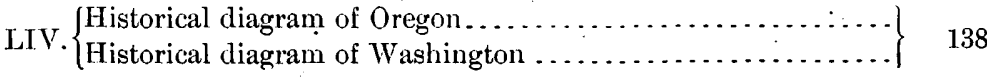




\title{
LE'T'TR OF TRANSMITTAL.
}

\author{
Deipartment OF THE InTERIOR, \\ United States Geological. Survey, \\ Washington, D. C., January 14, 1904.
}

SiR: I have the honor to transmit herewith, for publication as a bulletin, a revised (third) edition of the "Boundaries of the United States and of the Several States and Territories," as defined by treaty, charter, or statute. Besides giving the present status of these boundaries, I have endeavored to present an outline of the history of all important changes of territory, with the laws appertaining thereto.

This work was first published as Bulletin No. 13, in 1885. A second edition, much enlarged, constituted Bulletin No. 171, published in 1900 .

Very respectfully,

Henky Gan'sett, Geographer.

Hon. Charles D. Walcott,

Director United States Geological Survey. 

BOCNDARIES OF THE UNIFED STATES AND OR THE SEVERAL STATES AND TERRITORIISS, WITH AN OUTLLNE OP THE HISTORY OR ALL IMPORTANT CHANGES OP TERRITORY.

\author{
By Henry Gannett.
}

\author{
CH A P T E R I.
BOUNDARIES OF THE UNITED STATES, AND ADDITIONS TO ITS TERRITORY.

\title{
BOUNDARIES OF THE UNITED STATES.
}

\section{Provisional, Treaty with Great Britain.}

The original limits of the United States were first definitely laid down in the provisional treaty made with Great Britain in 1782. The second article of that treaty defines its boundaries as follows:

From the northwest angle of Nova Scotia, viz, that angle which is formed by a line drawn due north from the source of St. Croix River to the highlands; along the highlands which divide those rivers that empty themselves, into the river St. Lawrence from those which fall into the Atlantic Ocean, to the north westernmost head of Connecticut River; thence down along the middle of that river to the forty-fifth degree of north latitude; from thence, by a line due west on said latitude until it strikes the river Iroquois or Cataraquy (St. Lawrence); thence along the middle of said river into Lake Ontario, through the middle of said lake until it strikes the communication by water between that lake and Lake Erie; thence along the middle of said communication into Lake Erie, through the middle of said lake until it arrives at the water communication ketween that lake and Lake Huron; thence along the middle of said water communication into the Lake Huron; thence through the middle of said lake to the water communication between that lake and Lake Superior; thence through Lake Superior northward of the Isles Royal and Phelippeaux to the Long Lake; thence through the middle of said Long Lake, and the water communication between it and the Jake of the Woods, to the said Lake of the Woods; thence through the said lake to the most northwestern point thereof, and from thence on a due west course to the river Mississippi; thence by a line to be drawn along the middle of the said river Mississippi until it shall intersect the northernmost part of the thirty-first degree of north latitude. South by a line to be drawn due east from the determination of the line last mentioned; in the latitude of thirty-one degrees north of the Equator, to the middle of the river Apalachicola or Catahouche; thence along the middle thereof to its junction with the Flint River; thence straight to the head of St. Mary's River; and thence down along the middle of St. Mary's River to the Atlantic Ocean. East by a line to be drawn along the middle of the river St. Croix, 
from its mouth in the Bay of Fundy to its source, and from its source directly north to the aforesaid highlands which divide the rivers that fall into the Atlantic Ocean from those which fall into the river St. Lawrence; comprehending all islands within twenty leagues of any part of the shores of the United States and lying between lines to be drawn due east from the points where the aforesaid boundaries between Nova Scotia on the one part and East Florida on the other, shall respectively touch the Bay of Fundy and the Atlantic Ocean, excepting such islands as now are, or heretofore have been, within the limits of the said province of Nova Scotia.

\section{Treaty with Spain of 1798.}

The boundary between the United States and the Spanish Possessions, known as the Floridas, is reaffirmed in the treaty between the United States and Spain, made in 1795 , in the following term

The southern boundary of the United States, which divides their territory from the Spanish colonies of East and West Florida, shall be designated by a line beginning on the river Mississippi, at the northernmost part of the thirty-first degree of latitude north of the equator, which from thence shall be drawn due east to the middle of the river Apalachicola or Catahouche, thence along the middle thereof to its junction with the Flint; thence straight to the head of St. Mary's River, and thence down the middle thereof to the Atlantic Ocean.

\section{Definitrve Treatty withe Greatip Britain.}

The definitive treaty of peace with Great Britain, concluded September 3, 1783, defines the boundaries of the United States in terms similar to those of the provisional treaty.

The northern boundary became at once a fruitful source of dissension between the two countries. From the time of the conclusion of peace almost to the present day this line has been the subject of a series of treaties, commissions, and surveys for the purpose of interpreting its terms.

The following is in outline a history of the settlement of this boundary:

Treaty of London, 1794.

The fourth article of the treaty of London, signed November 19 , 1794, provided that-

Whereas it is uncertain whether the river Mississippi extends so far to the northward as to be intersected by a line to be drawn due west from the Lake of the Woods in the manner mentioned in the treaty of peace between His Majesty and the United States, etc., the two parties will proceed by amicable negotiation to regulate the boundary line in that quarter.

This matter was not settled, however, until 1818.

The fifth article of the same treaty makes provision for settling another doubtful point, as follows:

Whereas doubts have arisen what river was truly intended under the name of the river St. Croix mentioned in the said treaty of peace, and forming a part of the boundary there.n described, that question shall be referred to the final decision of commissions to be appointed in the following manner, viz. 
<smiles>C1CCCCC1</smiles> 


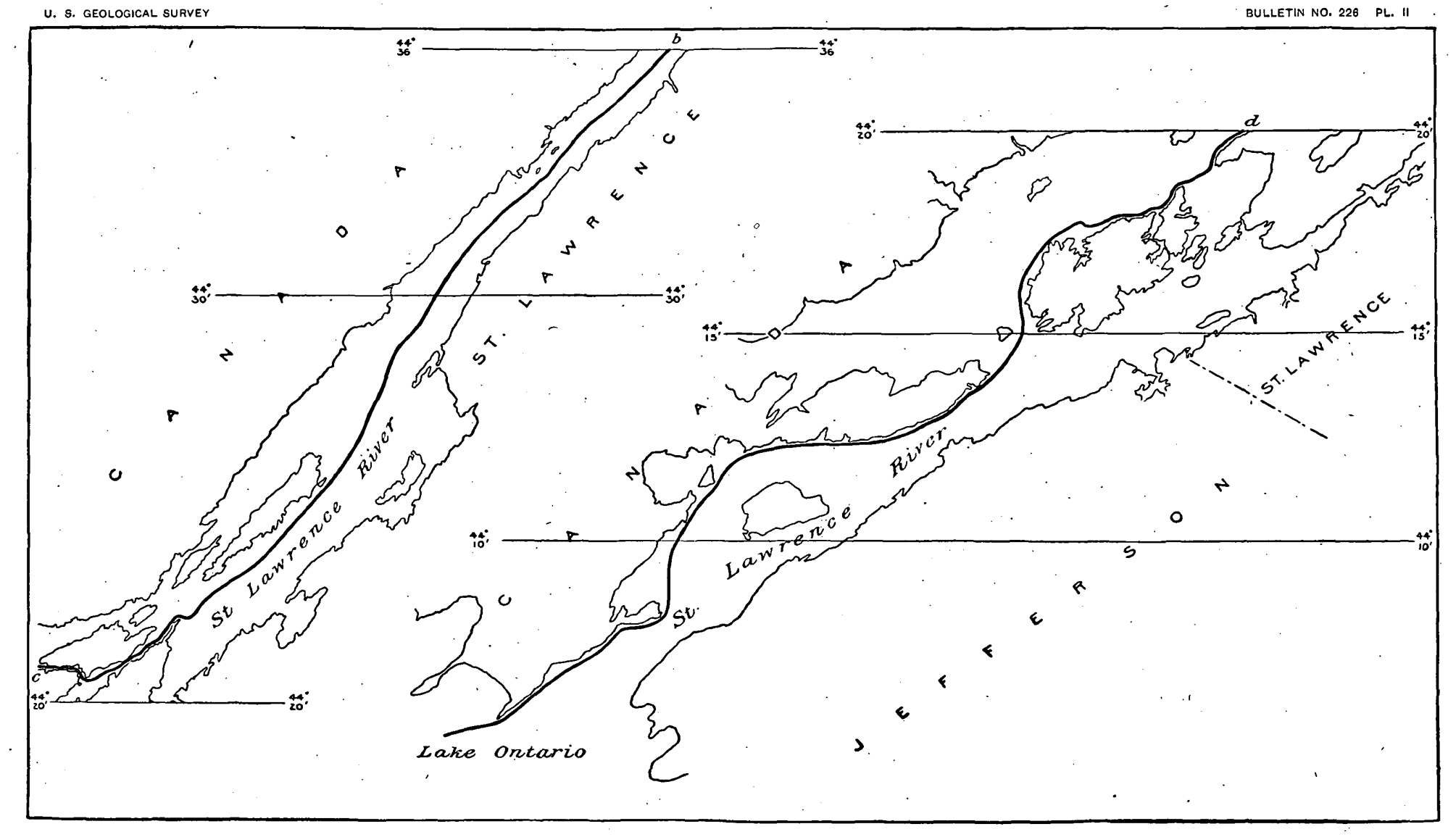




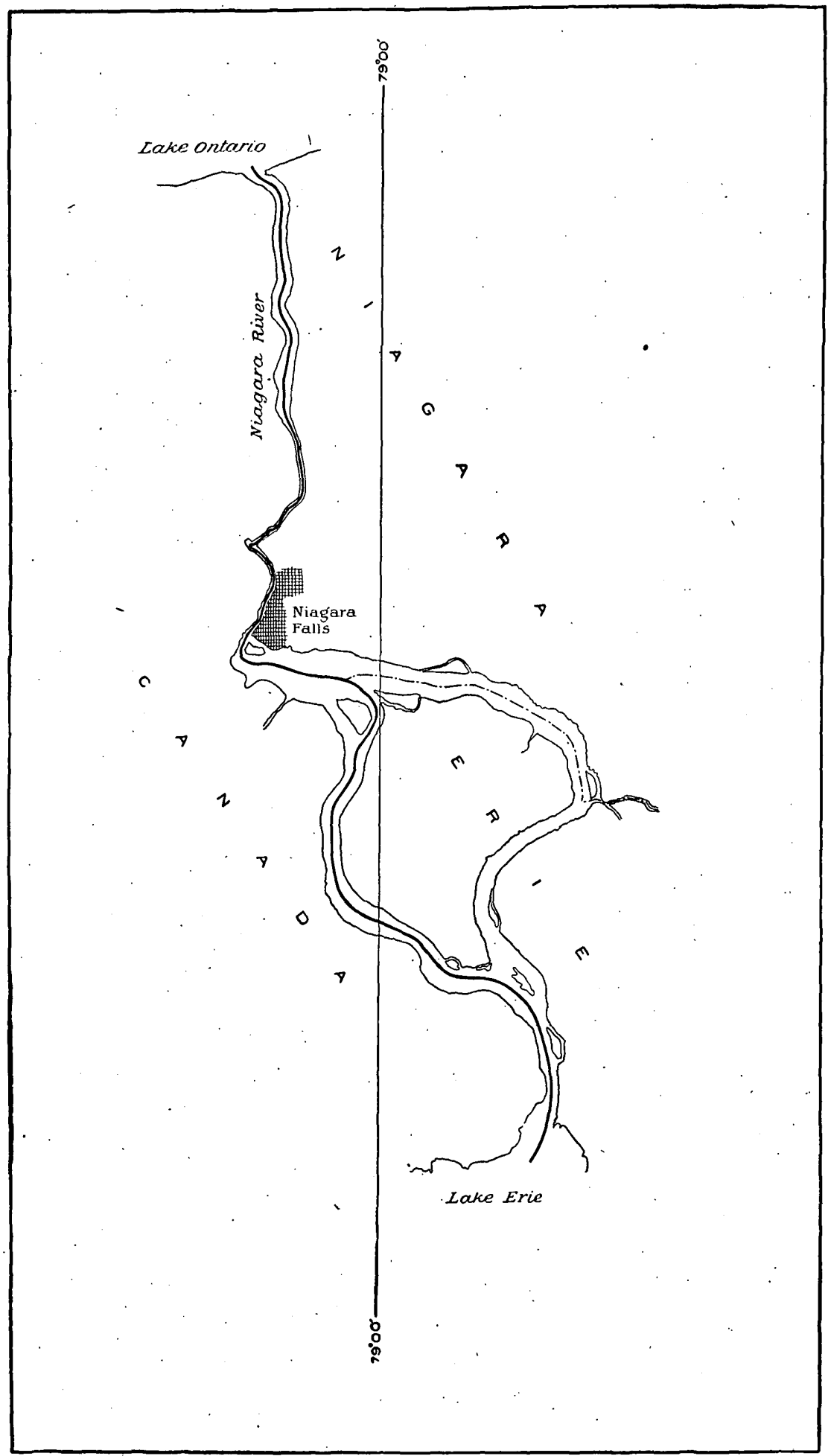


Here follow provisions that His Majesty and the President of the United States should each appoint a commissioner, and that these two commissioners should agree on a third, or, they failing to agree on the third, he was to be chosen by lot in their presence.

Which was the true St. Croix River had been a matter of controversy between the governments of Massachusetts and Nova Scotia since the year 1764 .

The commissioners appointed under the foregoing provisions decided, on the 25th of October, 1798, the river called Schoodiac and the northern branch thereof (called Cheputnaticook) to be the true river St. Croix, and that its source was at the northernmost headspring of the northern branch aforesaid. A monument was erected at that spot under the direction of the commissioners. (See Memoirs of Northeastern Boundary, Gallatin, pages 7, 8.)

\section{Treaty of Ghent.}

By the treaty of peace concluded at Ghent, December 24, 1814, it was agreed to provide for a final adjustment of the boundaries described in the treaty of 1783 , which had not yet been ascertained and determined, embracing certain islands in the Bay of Fundy and the whole of the boundary line from the source of the river St. Croix to the most northwestern point of the Lake of the Woods.

By article 4 provision was made for a board of commissioners to settle the title to several islands in the Bay of Passamaquoddy, which is a part of the Bay of Fundy, and the island of Grand Menan in the said Bay of Fundy.

The fifth article made provision for a board of commissioners to settle the boundary from the source of the river St. Croix northward to the highland which divides those waters that empty themselves into the river St. Lawrence from those which fall into the Atlantic Ocean, thence along said highlands to the northwesternmost head of Connecticut River, thence down along the middle of that river to the forty-fifth degree of north latitude, thence due west on said latitude until it strikes the river Iroquois or Cataraquy (St. Lawrence).

The sixth and seventh articles provided for commissioners to continue the line to the northwestern point of the Lake of the Woods.

(For further details see treaty, Statutes at Large, vol. 8, pp. 220-2.)

It was provided by this treaty that in case any of the boards of commissioners were unable to agree, they should make separately or jointly a report or reports to their respective Governments stating the points on which they differed, the grounds on which they based their respective opinions, etc.

These raports were to be referred to some friendly sovereign or state for arbitration.

The first and third boards of commissioners above mentioned came Bull. 226-04-2 
to an agreement, and those portions of the boundary were thus finally settled; but the commission appointed under the fifth article, after sitting nearly five years, could not agree on any of the matters referred to them, nor even on a general map of the country exhibiting the boundaries respectively claimed by each party. They accordingly made separate reports to their Governments, stating the points on which they differed and the grounds upon which their respective opinions had been formed.

The first of these commissions awarded Moore, Dudley, and Frederick Islands to the United States, and all other islands in Passamaquoddy Bay, and the island of Grand Menan, to Great Britain.

The following is the text of the report of the third of these commissions, which had under consideration that portion of the northern boundary between the point where the forty-fifth parallel of north latitude strikes the St. Lawrence and the point where the bounday reaches Lake Superior:

Decision of the commissioners under the sixth article of the treaty of Ghent, done at Utica, in the State of New York, 1.8th June, 1822.

We do decide and declare that the following-described line (which is more clearly indicated op a series of maps accompanying this report, exhibiting correct surveys and delineations of all the rivers, lakes, water communications, and islands embraced by the sixth article of the treaty of Ghent, by a black line shaded on the' British side with red and on the American side with blue; and each sheet of which series of maps is identified by a certificate, subscribed by the commissioners, and by the two principal surveyors employed by them) is the true boundary intended by the two before-mentioned treaties, that is to say:

Beginning at a stone monument, erected by Andrew Ellicot, esq., in the year 1817, on the south bank or shore of the said river Iroquois, or Cataraqui (now called the St. Lawrence), which monument bears south $74^{\circ} 45^{\prime}$ west, and is 1,840 yards distant from the stone church in the Indian village of St. Regis, and indicates the point at which the forty-fifth parallel of north latitude strikes the said river; thence running north $35^{\circ} 45^{\prime}$ west into the river, on a line at right angles with the southern shore, to a point 100 yards south of the opposite island, called Cornwall Island; thence turning westerly and passing around the southern and western sides of said island, keeping 100 yards distant therefrom, and following the curvatures of its shores, to a point opposite to the northwest corner or angle of said island; thence to and along the middle of the main river until it appros shes the eastern extremity of Barnhart's Island; thence northerly along the chan el which divides the lastmentioned island from the Canada shore, keeping 100 yards distant from the island, until it approaches Sheik's Island; thence along the middle of the strait which divides Barnhart's and Sheik's islands to the channel called the Long Sault, which separates the two last-mentioned islands from the lower Long Sault Island; thence westerly (crossing the center of the last-mentioned channel) until it approaches within 100 yards of the north shore of the Lower Sault Island; thence up the north branch of the river, keeping to the north of and near the Lower Sault Island, and also north of and near the Upper Sault, sometimes called Baxter's Island, and south of the two small islands marked on the map A and B, to the western extremity of the Upper Sault or Baxter's Island; thence, passing between the two islands called the Cats, to the midrle of the river above; thence along the middle of the river, keeping to 


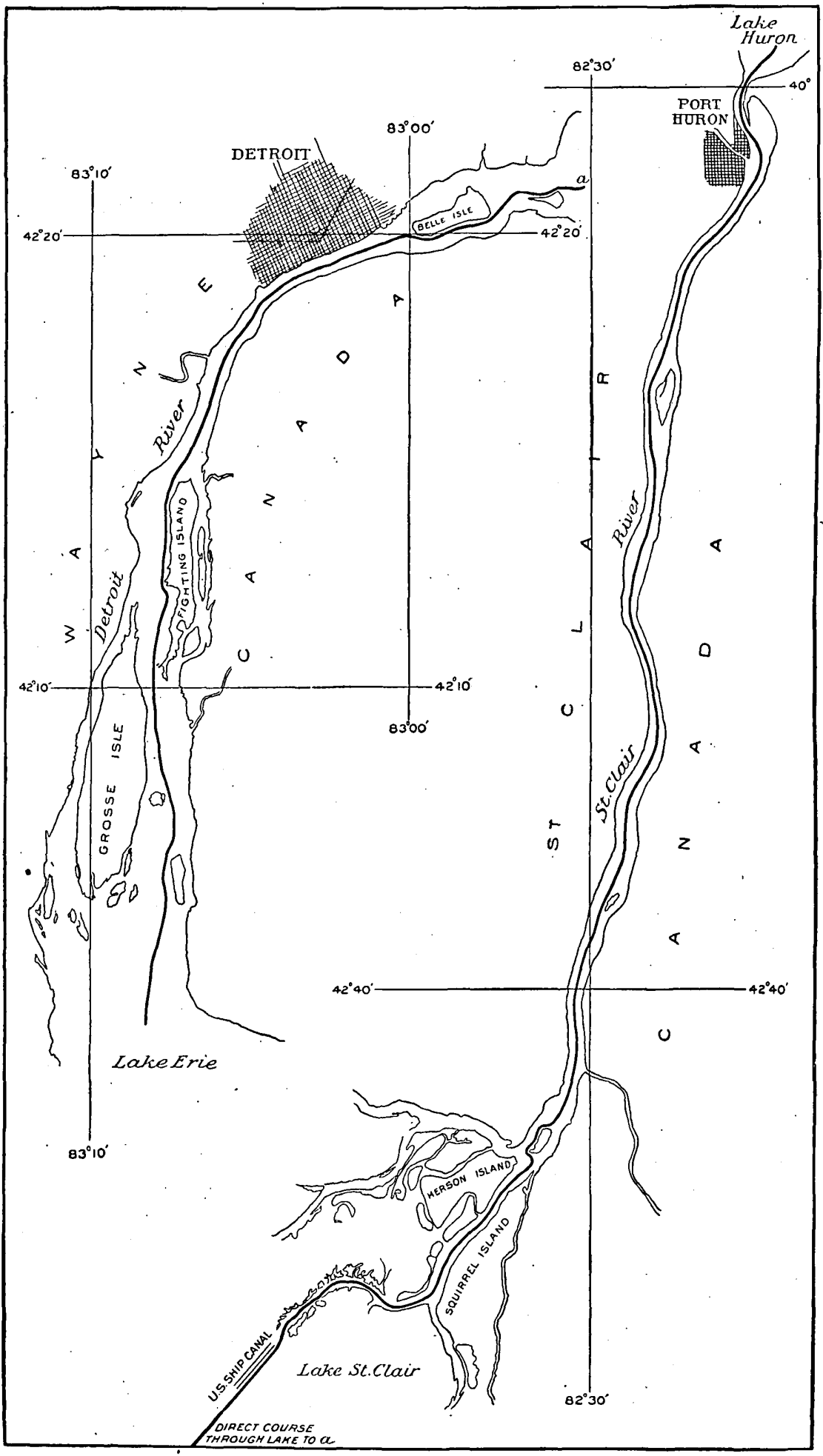

BOUNDARYY BETWEEN UNITED STATES AND CANADA IN ST, CLAIR AND DETROIT RIVERS. 
the north of the small islands marked C and D, and north also of Chrystler's Island, and of the small island next above it, marked $\mathrm{E}$, until it approaches the northeast angle of Goose Neck Island; thence along the passage which divides the lastmentioned island from the Canada shore, keeping 100 yards from the island to the upper end of the same; thence south of and near the two small islands called the Nut Islands; thence north of and near the island marked $\mathrm{F}$, and also of the island called Dry or Smuggler's Island; thence passing between the islands marked $G$ and $H$ to the north of the island called Isle au Rapid Platt; thence along the north side of the lastmentioned island, keeping 100 yards from the shore, to the upper end thereof; thence along the middle of the river, keeping to the south of and near the islands called Coussin (or Tussin) and Presque.Isle; thence up the river, keeping north of and near the several Gallop Isles numbered on the map 1, 2,3,4, 5, 6, 7, 8, 9, and 10, and also of Tick, Tibbits, and Chimney islands, and south of and near the Gallop Isles numbered 11, 12, and 13, and also of Duck, Drummond, and Sheep islands; thence along the middle of the river, passing north of island No. 14, south of 15 and 16 , north of 17 , south of $18,19,20,21,22,23,24,25$, and 28 , and north of 26 and 27 ; thence along the middle of the river, north of Gull Island and of the islands Nos. 29, 32, 33, 34, 35, Bluff Island, and Nos. 39, 44, and 45, and to the south of Nos. 30, 31, 36, Grenadier Island, and Nos. 37, 38, 40, 41, 42, 43, 46, 47, and 48, until it approaches the east end of Well's Island; thence to the north of Well's Island, and along the strait which divides it from Rowe's Island, keeping to the north of the small islands Nos. 51, 52, 54, 58, 59, and 61 , and to the south of the small islands numbered and marked $49,50,53,55$, 57,60 , and $\mathrm{H}$, until it approaches the northeast point of Grindstone Island; thence to the north of Grindstone Island, and keeping to the north also of the small islands Nos. $63,65,67,68,70,72,73,74,75,76,77$, and 78 , and to the south of Nos. 62,64 , 66,69 , and 71 , until it approaches the southern point of Hickory Island; thence passing to the south of Hickory. Island and of the two small islands lying near its southern extremity, numbered 79 and 80 ; thence to the south of Grand or Long Island, keeping near its southern shore, and passing to the north of Carlton Island, until it arrives opposite to the southwestern point of said Grand Island, in Lake Ontario; thence, passing to the north of Grenadier, Fox, Stony, and the Gallop islands, in Lake Ontario, and to the south of and near the islands called the Ducks, to the middle of the said lake; thence westerly along the middle of said lake to a point opposite the mouth of the Niagara River; thence to and up the middle of the said river to the Great Falls; thence up the Falls through the point of the Horse Shoe, keeping to the west of Iris or Goat Island, and of the group of small islands at its head, and following the bends of the river so as to enter the strait between Navy and Grand islands; thence along the middle of said strait to the head of Navy Island; thence to the west and south of and near to Grand and Beaver islands, and to the west of Strawberry, Squaw, and Bird islands to Lake Erie; thence southerly and westerly along the middle of Lake Erie in a direction to enter the passage immediately south of Middle Island, being one of the easternmost of the group of islands lying in the western part of said lake; thence along the said passage, proceeding to the north of Cunningham's Island, of the three Bass Islands, and of the Western Sister, and to the south of the islands ,called the Hen and Chickens, and of the Eastern and Middle Sisters; thence to the middle of the mouth of the Detroit River in a direction to enter the channel which divides Bois Blanc and Sugar islands; thence up the said channel to the west of Bois Blanc Island, and to the east of Sugar, Fox, and Stony islands, until it approaches Fighting or Great Turkey Island; thence along the western side and near the shore of said last-mentioned island to the middle of the river above the same; thence along the middle of said river, keeping to the southeast of and near Hog Island, and to the northwest of and near the island Isle à la Pêche, to Lake Saint Clair; thence through the middle of said lake in a direction to enter that mouth or channel of the river St. Clair which is usually denominated the Old Ship Channel; 
thence along the middle of said channel, between Squirrel Island on the southeast and Herson's Island on the northwest, to the upper end of the last-mentioned island, which is nearly opposite to Point au Chenes, on the American shore; thence along the middle of the river Saint Clair, keeping to the west of and near the islands called Belle Rivièré Isle and the Isle aux Cerfs, to Lake Huron; thence through the middle of Lake Huron in a direction to enter the strait or passage between Drummond's Island on the west and the Little Maniton Island on the east; thence through the middle of the passage which divides the two last-mentioned islands; thence, turning northerly and westerly, around the eastern and northern shores of 'Drummond's Island, and proceeding in a direction to enter the passage between the island of Saint Joseph's and the American shore, passing to the north of the intermediate islands Nos. $61,11,10,12,9,6,4$, and 2 , and to the south of those numbered 1.5, 13, 5, and 1; thence up the said last-mentioned passage, keeping near to the island Saint Joseph's, and passing to the north and east of Isle it la Crosse and of the small islands numbered $16,17,18,19$, and 20 , and to the south and west of those numbered 21, 22, and 23, until it strikes a line (drawn on the map with black ink and shaded on one side of the point of intersection with blue and on the other with red) passing across the river at the head of Saint Joseph's I'sland and at the foot of the Neebish Rapids, which line denotes the termination of the boundary directed to be run by the sixth article of the treaty of Ghent.

And the said commissioners do further decide and declare that all the islands lying in the rivers, lakes, and water communications between the before-described boundary line and the adjacent shores of Upper Canada do, and each of them does, belong to His Britannic Majesty, and that all the islands lying in the rivers, lakes, and water communications between the said boundary line and the adjacent shores of the United States or their territories do, and each of them does, belong to the United States of America, in conformity with the true intent of the second article of the said treaty of 1783 , and of the sixth article of the treaty of Ghent.

In accordance with the terms of this treaty, a survey was made of the St. Lawrence and the Great Lakes, and a map prepared. This was photolithographed and published, in 29 sheets, by the United States Light-House Board, in 1891.

By the second article of the convention with Great Britain-1818the boundary line was extended westward along the forty-ninth parallel of latitude to the "Stony" (Rocky) Mountains, while beyond these mountains the treaty provided that the country should remain open to both parties. The terms of the treaty are as follows:

Article 2. It is agreed that a line drawn from the most northwestern point of the Lake of the Woods along the forty-ninth parallel of north latitude, or if the said point shall not be in the forty-ninth parallel of north latitude, then that a line drawn from the said point due north or south, as the case may be, until the said line shall intersect the said parallel of north latitude, and from the point of such intersection due west along and with the said parallel, shall be the line of demarkation between the territories of the United States and those of His Britannic Majesty, and that the said line shall form the northern boundary of the said territories of the United States and the southern boundary of the territories of His Britannic Majesty from the Lake of the Woods to the Stony Mountains.

Article 3. It is agreed that any country that may be claimed by either party on the northwest coast of America, westward of the-Stony Mountains, shall, together with its harbours, bays, and creeks, and the navigation of all rivers within the same, be free and open, for the term of ten years from the date of the signature of the present convention, to the vessels, citizens, and subjects of the two powers; it being 


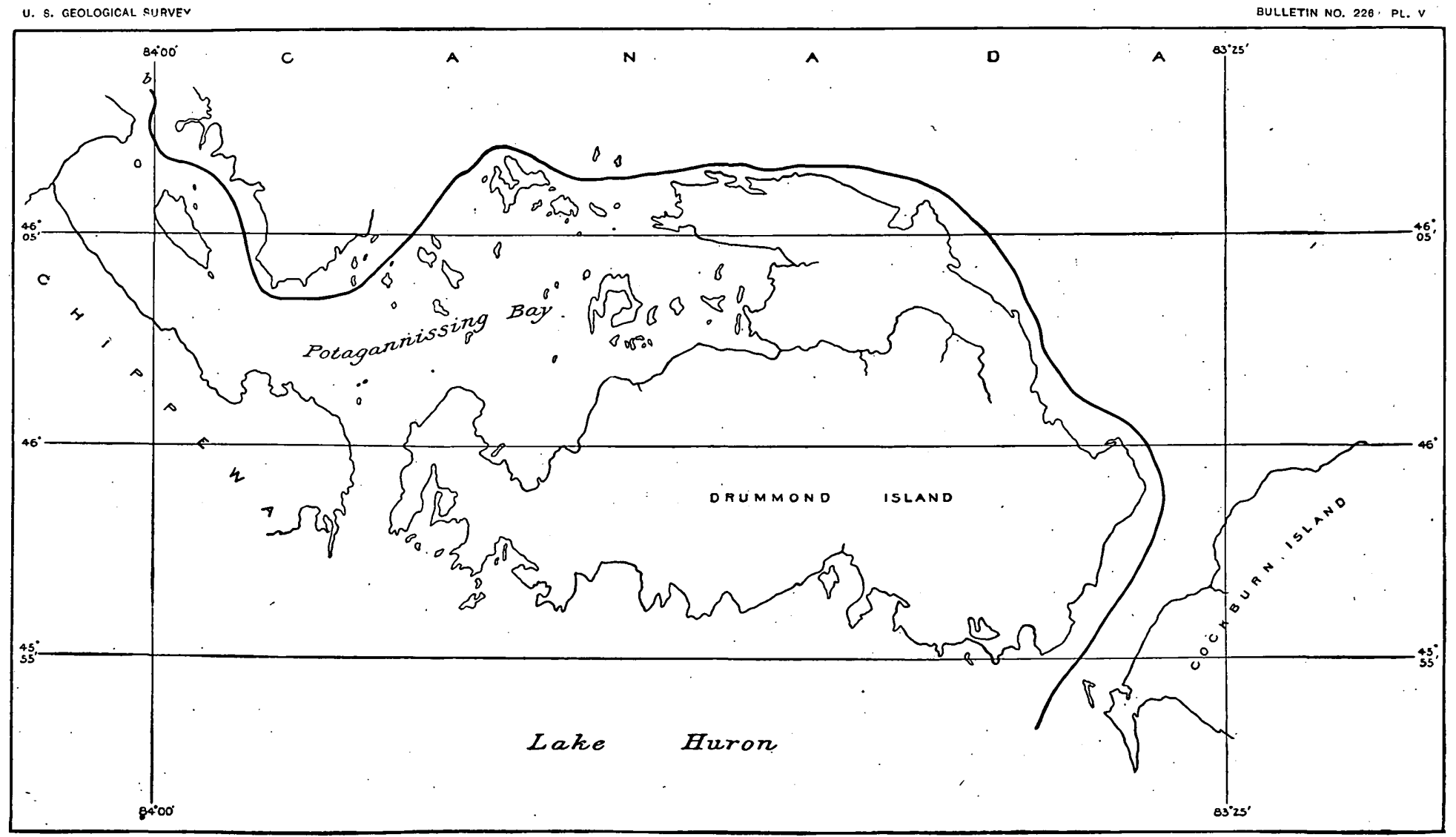

BOUNDARY BETWEEN MICHIGAN AND CANADA THROUGH ST. MARY RIVER. 


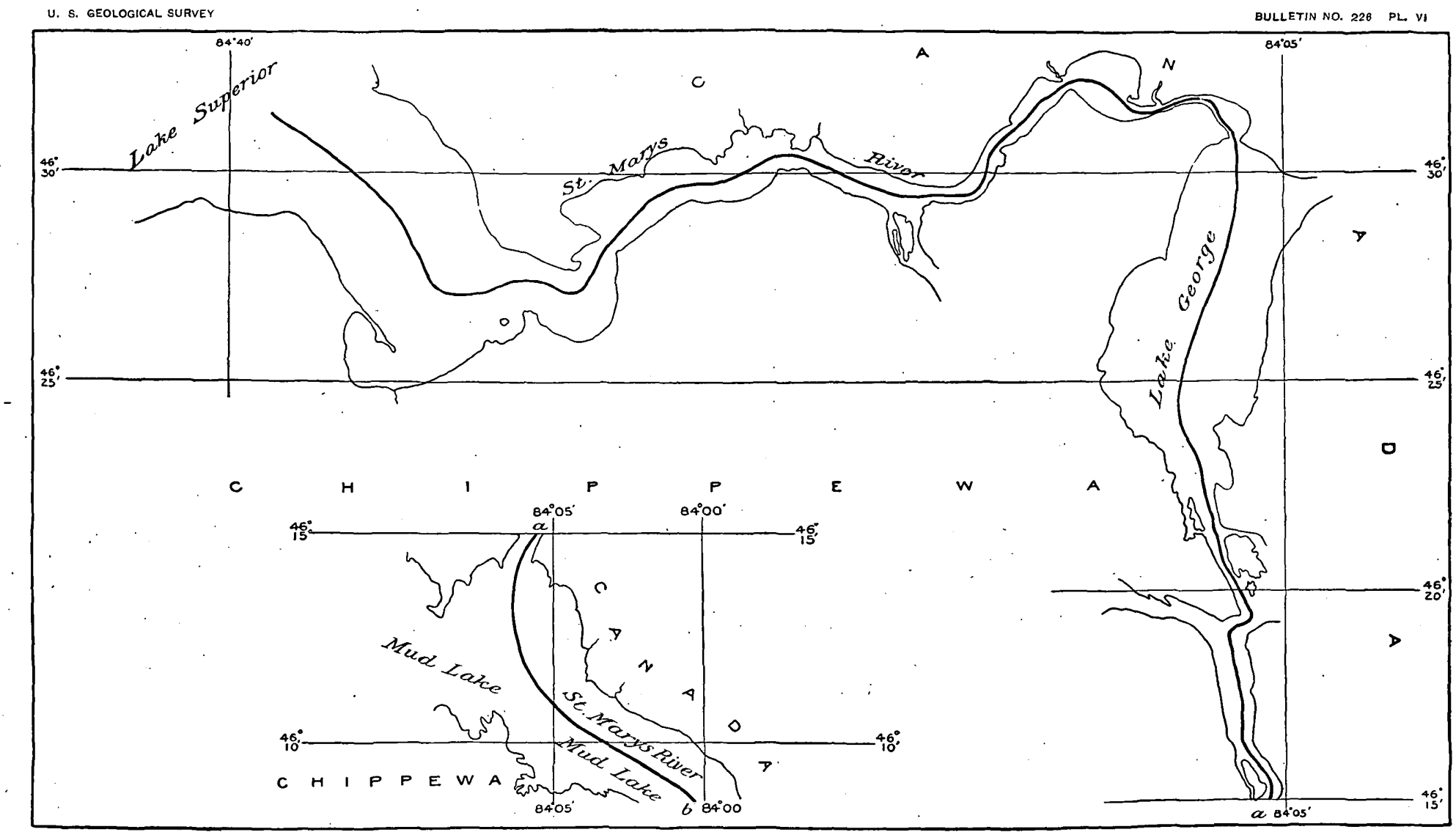

BOUNDARY BETWEEN MICHIGAN AND CANADA THROUGH ST, MARY RIVER. 
well understood that this agreement is not to be construed to the prejudice of any claim which either of the two high contracting parties may have to any part of the said country, nor shall it be taken to affect the claims of any other power or state to any part of the said country; the only object of the high contracting parties in that respect being to prevent disputes and differences amongst themselves.

In 1824 negotiations were resumed between the two countries for the settlement, among other things, of the boundary west of the Rocky Mountains, but no conclusion was reached; the claim of the English Government being that the boundary line should follow the forty-ninth parallel westward to the point where this parallel strikes the great northwestern branch of Columbia River, thence down the middle of that river to the Pacific Ocean.

In $1 \$ 26$ negotiations were resumed, and several compromises were proposed by both parties, but without satisfactory results. After this the whole matter remained in abeyance intil the special mission of Lord Ashburton to this country in 1842.

Meanwhile the unsettled questions regarding the northeastern boundary again came up.

The case having reached that stage at which it became necessary to refer the points of difference to a friendly sovereign or state, the two powers found it expedient to regulate the proceedings and make provisions in relation to such reference, and on the 29th September, 1827, concluded a convention to that effect.

The respective claims of the United States and Great Britain were as follows, viz:

Boundary claimed by United States.-From the source of the river St. Croix (a point of departure mutually acknowledged) the boundary should be a due north line for about 140 miles, crossing the river St. John at about 75 miles. At about 97 miles it reaches a ridge or highland which divides tributary* streams of the river St. John, which falls into the Bay of Fundy, from the waters of the river Ristigouche, which falls through the Bay des Chaleurs into the Gulf of St: Lawrence. In its further course the said due north line, after crossing several upper branches of the river Ristigouche, reaches, at about 140 miles, the highlands which divide the waters of the said river Ristigouche from the tributary streams of the river Metis, which falls into the river St. Lawrence.

Thence the line should run westerly and southwesterly along the highlands which divide the sources of the several rivers (from the Metis to the St. Francis) that empty themselves into the river St. Lawrencefrom the sources of the tributaries of the rivers Ristigouche, St. John, Penobscot, Kennebec, and Connecticut, all which either mediately or immediately fall into the Atlantic Ocean.

Boundary claimed by Great Britain.-From the source of the river St. Croix the boundary should be a due north line about 40 miles to a point at or near Mars Hill; thence it should run westerly about 115 
miles along the highlands that divide the sources of the tributaries of the river St. John from the sources of the river Penobscot to a 'spot called Metjarmette Portage, near the source of the river Chaudière.

From this point the line coincides with the line claimed by the United States until the northwesternmost head of the Connecticut River is reached. Great Britain claimed one of several small streams to be the northwesternmost tributary of the Connecticut River, and the United States another.

Arbitration by King of twhe Nethertands.

The King of the Netherlands was selected in 1829 by the two Governments as the arbiter, and each laid before him, in conformity with the provisions of the convention, all the evidence intended to be brought in support of its claim, and two separate statements of the respective cases. These four statements, which embrace the arguments at large of each party, respectively, have been printed, but not published (1840).

The award of the King of the Netherlands, made in 1831, was as follows, viz:

$*$

*

*

*

$*$

*

*

We are of the opinion that it will be suitable ( $i l$ conviendra) to adopt as the boundary of the two States a line drawn due north from the source of the river St. Croix to the point where it intersects the middle of the thalweg of the river St. John; thence the middle of the thalweg of that river, ascending it to the point where the river St. Francis empties itself into the river St. John; thence the middle of the thalweg of the river Saint Francis, ascending it to the source of its southwesternmost branch, which source we indicate on the Map A by the letter X, authenticated by the signature of our minister of foreign affairs; thence in a line drawn due west to the point where it unites with the line claimed by the United States of America and delineated on the May A; thence said line to the point at which, according to said map, it coincides with that claimed by Great Britain, and thence the line traced on the map by the two powers to the northwesternmost source of Connecticut River.

We are of the opinion that the stream situated farthest to the northwest, among these which fall into the northernmost of the three lakes, the last of which bears the name of Connecticut Lake, must be considered as the northwesternmost head of Connecticut River.

We are of the opinion that it will be suitable $(i l$ conviendra) to proceed to fresh operations to measure the observed latitude in order to mark out the boundary from river Connecticut along the parallel of the forty-fifth degree of north latitude to the river Saint Lawrence, named in the treaties Iroquois or Cataraquy, in such a manner, however, that, in all cases, at the place called Rouse's Point the territory of the United States of America shall extend to the fort erected at that place, and shall include said fort and its kilometrical radius (rayon kilometrique).

However disposed the Government of the United States might have been to acquiesce in the decision of the arbiter, it had not the power to change the boundaries of a State without the consent of the State. Against that alteration the State of Maine entered a solemn protest by 


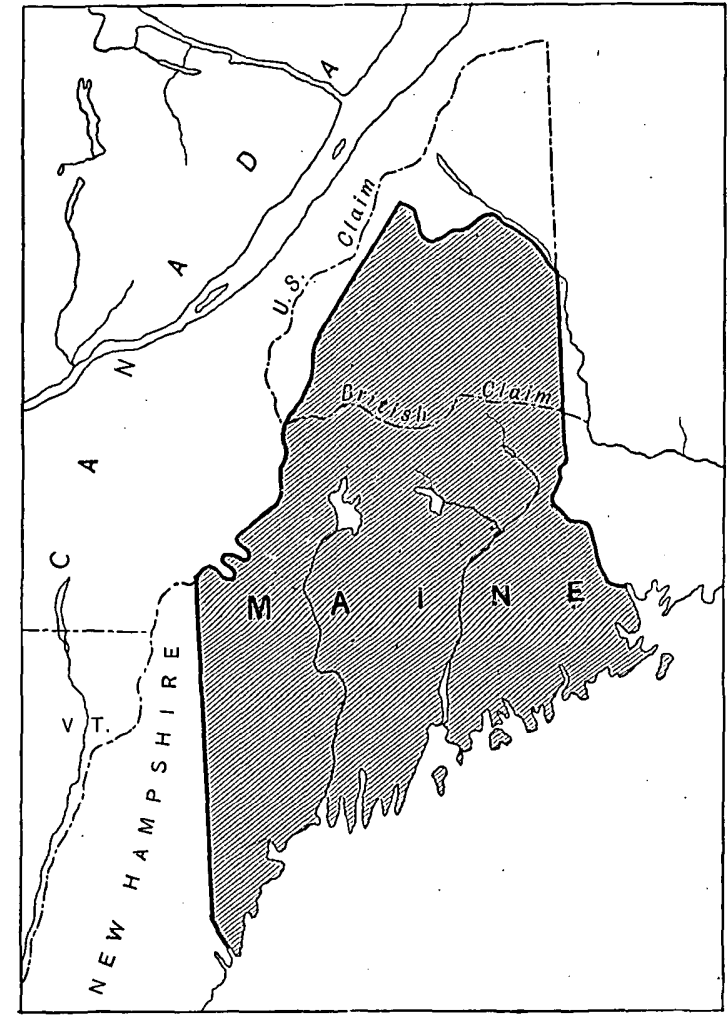

NORTHERN BOUNDARY OF MAINE, SHOWING UNITED STATES AND BRITISH CLAIMS.

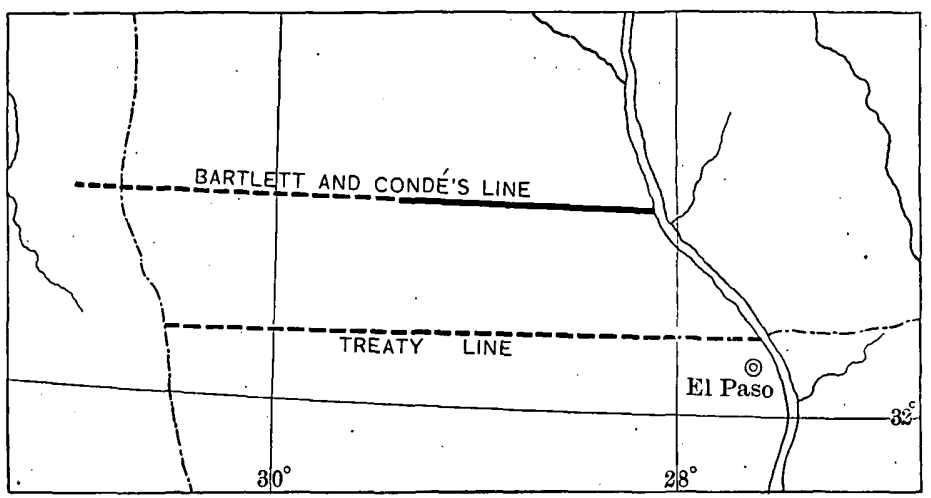

PORTION OF DISTURNELL'S MAP OF SOUTHWESTERN BOUNDARY, 1847 (SEE PAGES 23-24). 
the resolution of 19th January, 1832. And the Senate of the United States did accordingly refuse to give its assent to the award.

The arbitration of the King of the Netherlands having failed, fruitless negotiations ensued for a period of eleven years. Unsuccessful attempts were made to conclude an agreement preparatory to another arbitration. The subject became a matter of great irritation, collisions occurred in the contested territory, and for a time it seemed certain that the controversy would result in war between the two powers. In 1842, however, Great Britain gave unequivocal proof of her desire for the preservation of peace, and an amicable arrangement of the matter at issue, by the special mission of Lord Ashburton to the United States. The subject of this mission was the settlement, not only of the northeastern boundary, but the northern boundary west of the Rocky Mountains. Regarding this object of his mission, Lord Ashburton's instructions gave as the ultimatum of the English Government the boundary as above claimed (p. 15), and, naturally, his mission had no result, as far as this portion of the boundary was concerned.

An agreement was reached, however, in regard to the northeastern boundary, which, the consent of the State of Maine having been obtained, was embodied in the treaty concluded August 9, 1842.

Treaty with Great Britain, 1842.

The following is the text of the portion of this treaty relating to the boundary:

Article I. It is hereby agreed and declared that the line of boundary shall be as follows: Beginning at the monument at the source of the river St. Croix, as designated and agreed to by the commissioners uncler the fifth article of the treaty of 1794, between the Governments of the United States and Great Britain; thence north, following the exploring line run and marked by the surveyors of the two Governments in the years 1817 and 1818, under the fifth article of the treaty of Ghent, to its intersection with the river St. John, and to the middle of the channel thereof; thence up the middle of the main channel of the said river St. John, to the mouth of the river Saint Francis; thence up the middle of the channel of the said river St. Francis, and of the lakes through which it flows, to the outlet of the Lake Pohenagamook; thence southwesterly, in a straight line, to a point on the northwest branch of the river St. John, which point shall be ten miles distant from the main branch of the St. John, in a straight line, and in the nearest direction, but if the said point shall be found to be less than seven miles from the nearest point of the summit or crest of the highlands that divide those rivers which empty themselves into the river St. Lawrence from those which fall into the river St. John, there the said point shall be made to recede down the said north west branch of the river St. John to a point seven miles in a straight line from the said summit or crest; thence in a straight line, in a course about south, eight degrees west, to the point where the parallel of latitude $46^{\circ} 25^{\prime}$ north intersects the southwest branch of the St. John's; thence southerly, by the said branch, to the source thereof in the highlands at the Metjarmette portage; thence down along the said highlands which divide the waters which empty themselves into the river Saint Lawrence from those which fall into the Atlantic Ocean, to the head of Hall's stream; thence down the 
middle of said stream till the line thus run intersects the old line of boundary surveyed and marked by Valentine and Collins, previously to the year 1.774 , as the 45 th degree of north latitude, and which has been known and understood to be the line of actual division between the States of New York and Vermont on one side, and the British province of Canada on the other; and from said point of intersection, west, along the said dividing line, as heretofore known and understood, to the Iroquois or St. Lawrence River.

ARTICLE II. It is moreover agreed that, from the place where the joint commissioners terminated their labors under the sixth article of the treaty of Ghent, to wit, at a point in the Neebish channel, near Muddy Lake, the line shall run into and along the ship channel, between St. Joseph and Saint Tammany islands, to the division of the channel at or near the head of St. Joseph's Island; thence turning eastwardly and northwardly around the lower end of St. George's or Sugar Island, and following the middle of the channel which divides St. George's from St. Joseph's Island; thence up the east Neebish channel, nearest to St. George's Island, through the middle of Lake George; thence west of Jonas' Island, into St. Mary's River, to a point in the middle of that river, about one mile above St. George's or Sugar Island, so as to appropriate and assign the said island to the United States; thence, adopting the line traced on the maps by the commissioners, through the river St. Mary and Lake Superior, to a point north of Ile Royale, in said lake, one hundred yards to the north and east of Ile Chapeau, which last mentioned island lies near the northeastern point of Ile Royale, where the line marked by the commissioners terminates; and from the last-mentioned point, southwesterly, through the middle of the sound between Ile Royale and the northwestern mainland, to the mouth of Pigeon River, and up the said river, to and through the north and south Fowl Lakes, to the lakes of the height of land between Lake Superior and the Lake of the Woods; thence along the water communication to Lake Saisaginaga, and through that lake; thence to and through Cypress Lake, Lac du Bois Blanc, Lac la Croix, Little Vermillion Lake, and Lake Namecan, and through the severel smaller lakes, straits, or streams, connecting the lakes here mentioned to that point in Lac la Pluie, or Rainy Lake, at the Chaudière Falls, from which the commissioners traced the line to the most northwestern point of the Lake of the Woods; thence, along the said line, to the said most north western point, being in latitude $49^{\circ} 23^{\prime} 55^{\prime \prime}$ north, and in longitude $95^{\circ} 14^{\prime} 38^{\prime \prime}$ west from the observatory at Greenwich; thence, according to existing treaties, due south to its intersection with the forty-ninth parallel of north latitude, and along that parallel to the Rocky Mountains. ' It being understood that all the water communications and all the usual portages along the line from Lake Superior to the Lake of the Woods, and also Grand Portage, from the shore of Lake Superior to the Pigeon River, as now actually used, shall be free and open to the use of the citizens and subjects of both countries.

ARTICLE VII. It is further agreed that the channels in the river St. Lawrence, on both sides of the Long Sault Islands, and of Barnhart Island; the channels in the river Detroit, on both sides of the island Bois Blanc, and between that island and both the American and Canadian shores, and all the several channels and passages between the various islands lying near the junction of the river St. Clair with the lake of that name, shall be equally free and open to the ships, vessels, and boats of both parties.

Between 1843 and 1846 there was considerable negotiation regarding the boundary west of the Rocky Mountains, resulting finally in the Webster-Ashburton treaty, which defined the boundary as far west as the straits of Juan de Fuca. The following is that portion of the treaty which defines the boundary. 


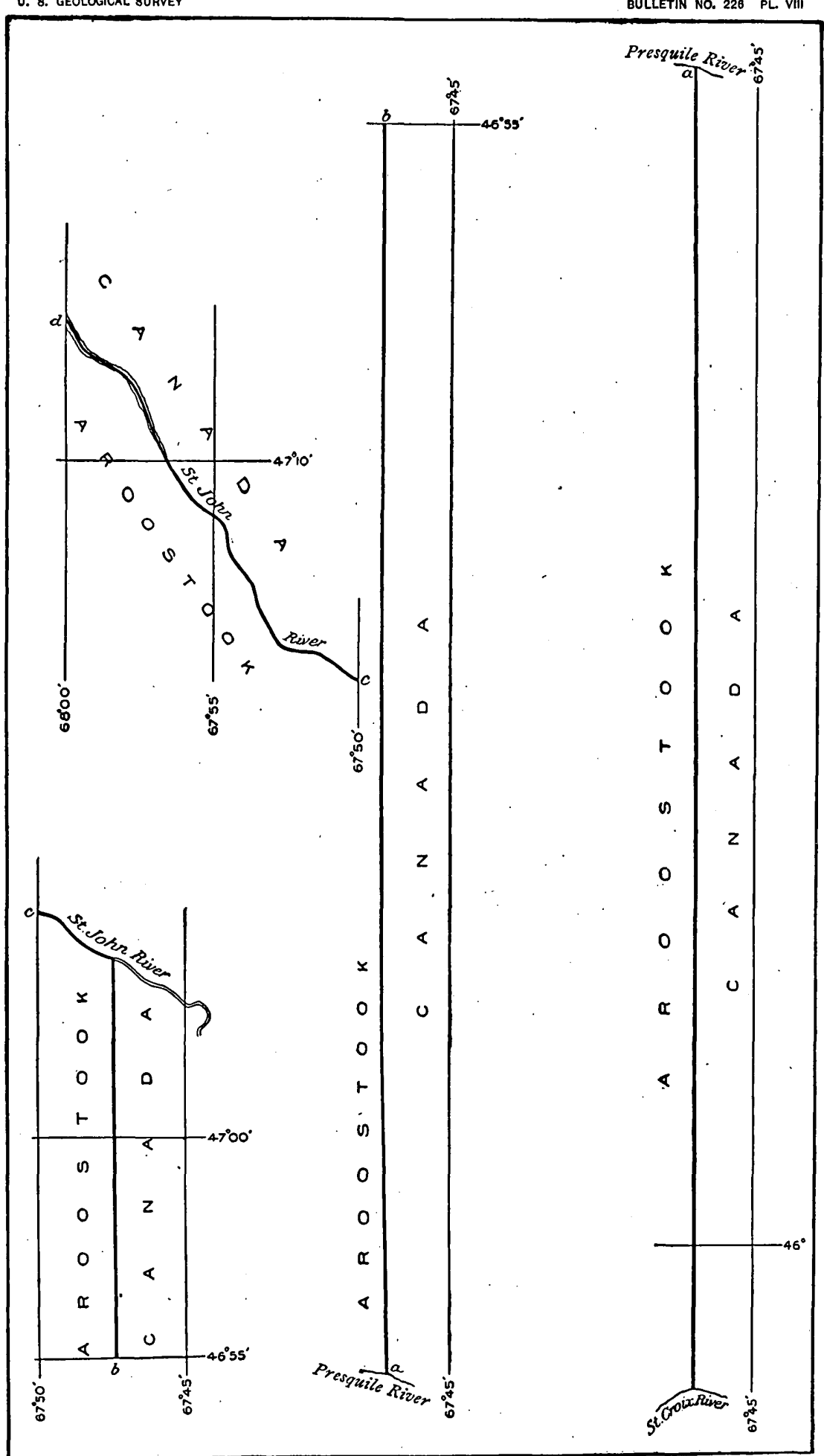

BOUNDARY BETWEEN MAINE AND CANADA

Bull. 226-04-3 


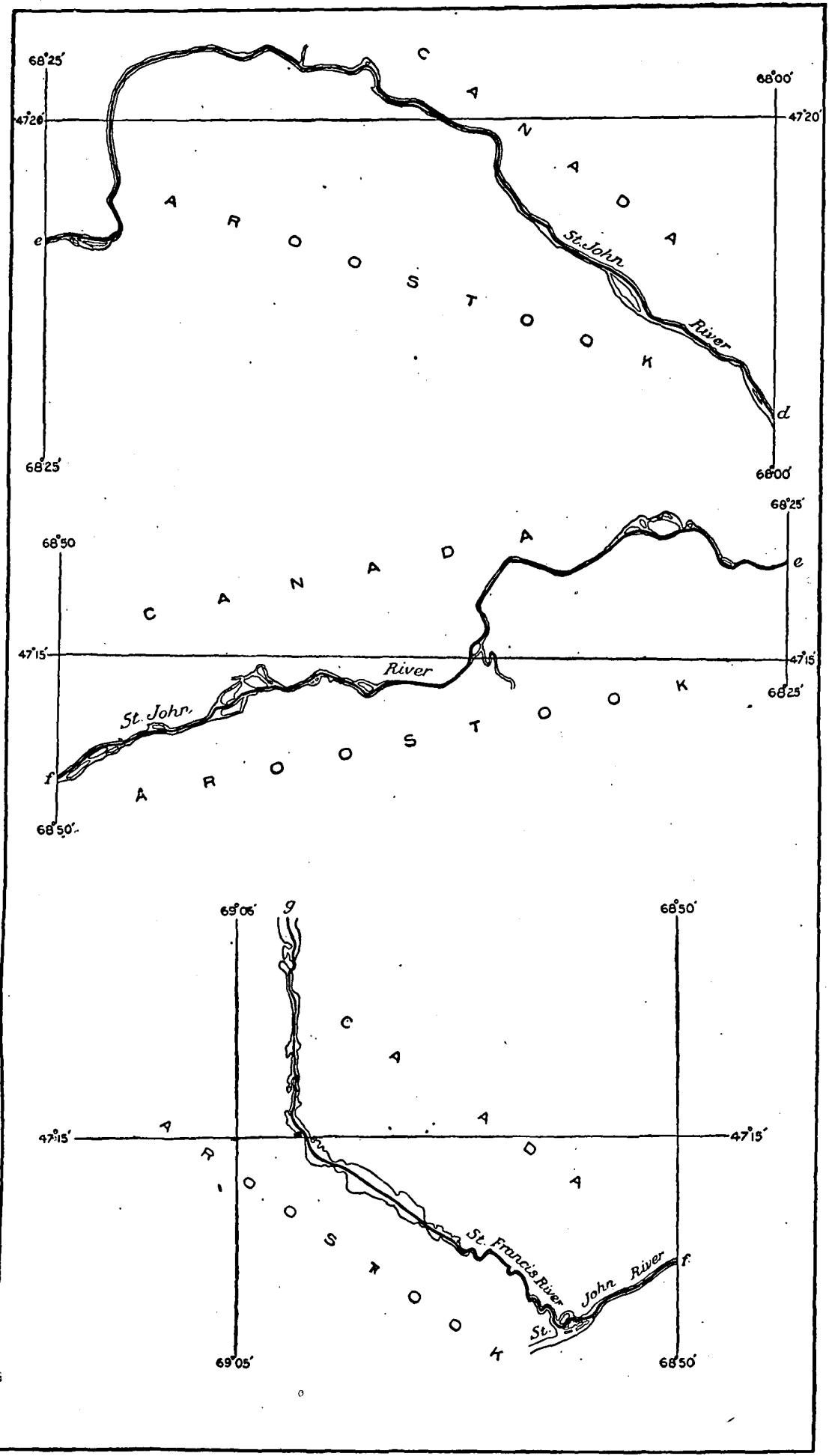

BOUNDARY BETWEEN MAINE AND CANADA. 


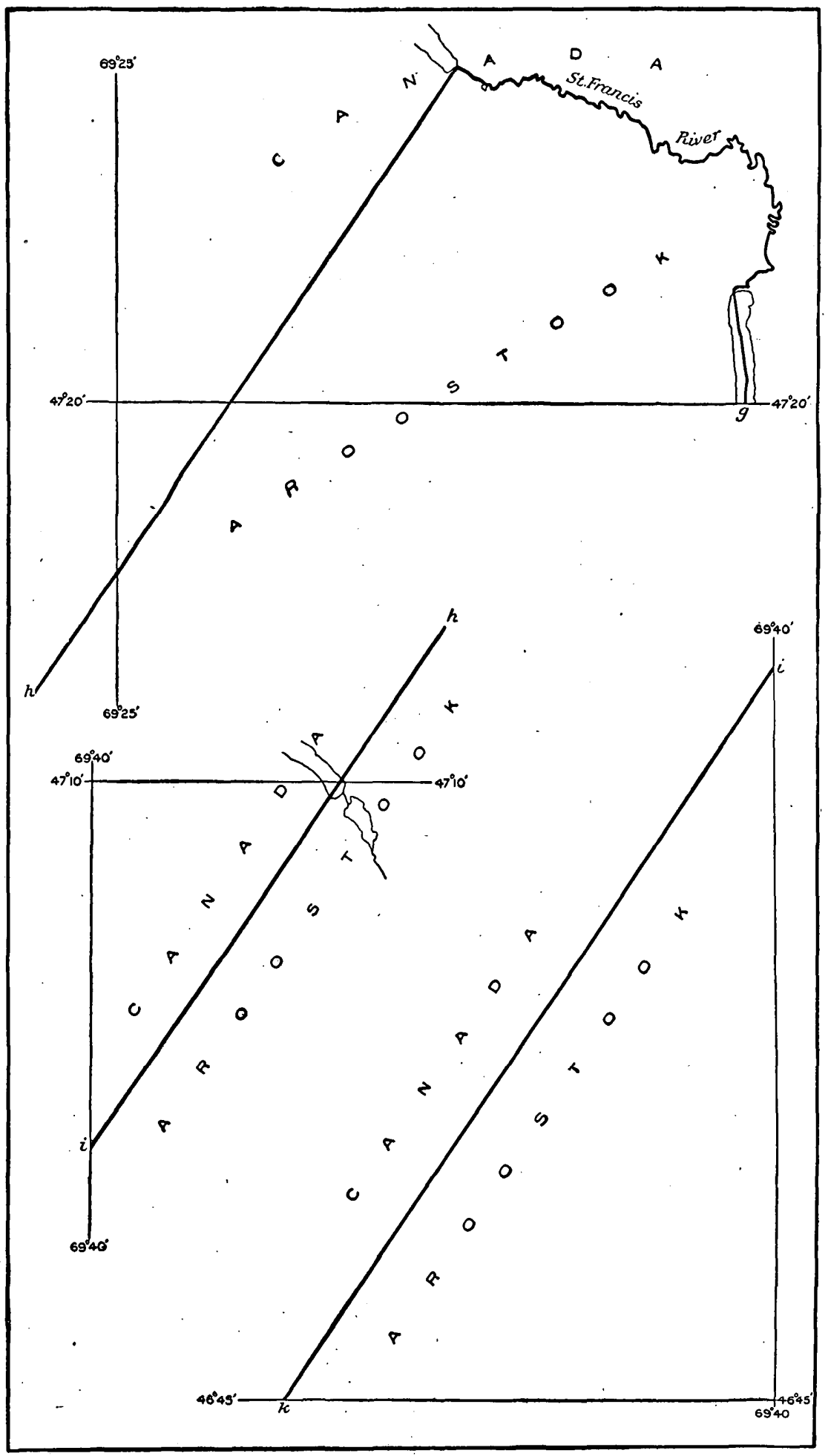

BOUNDARY BETWEEN MAINE AND CANADA. 
U. 8, GEOLOGICAL SUAVEY

BULLETIN NO. 226 PL. XI

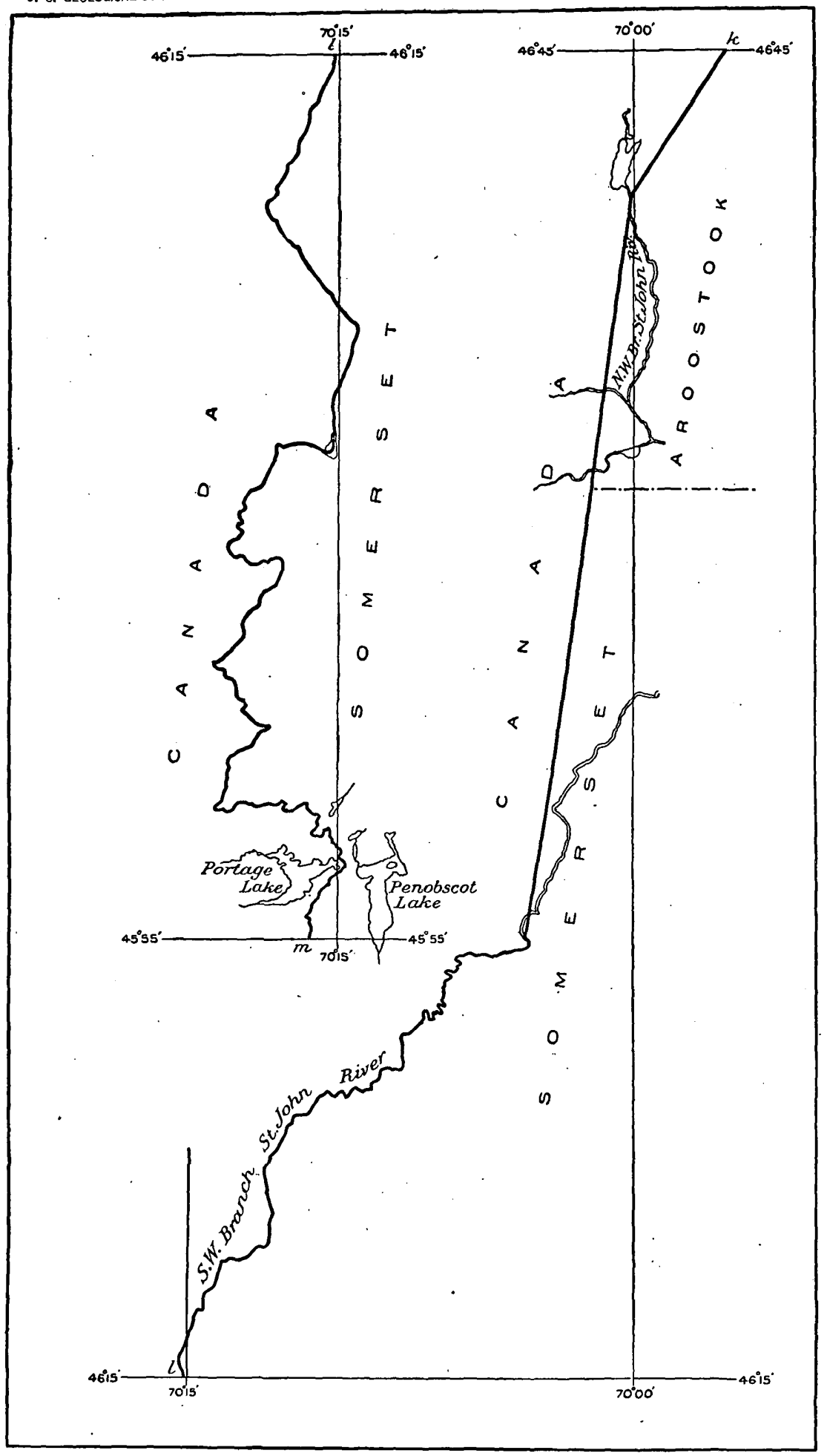

BOUNDARY BETWEEN MAINE AND CANADA. 


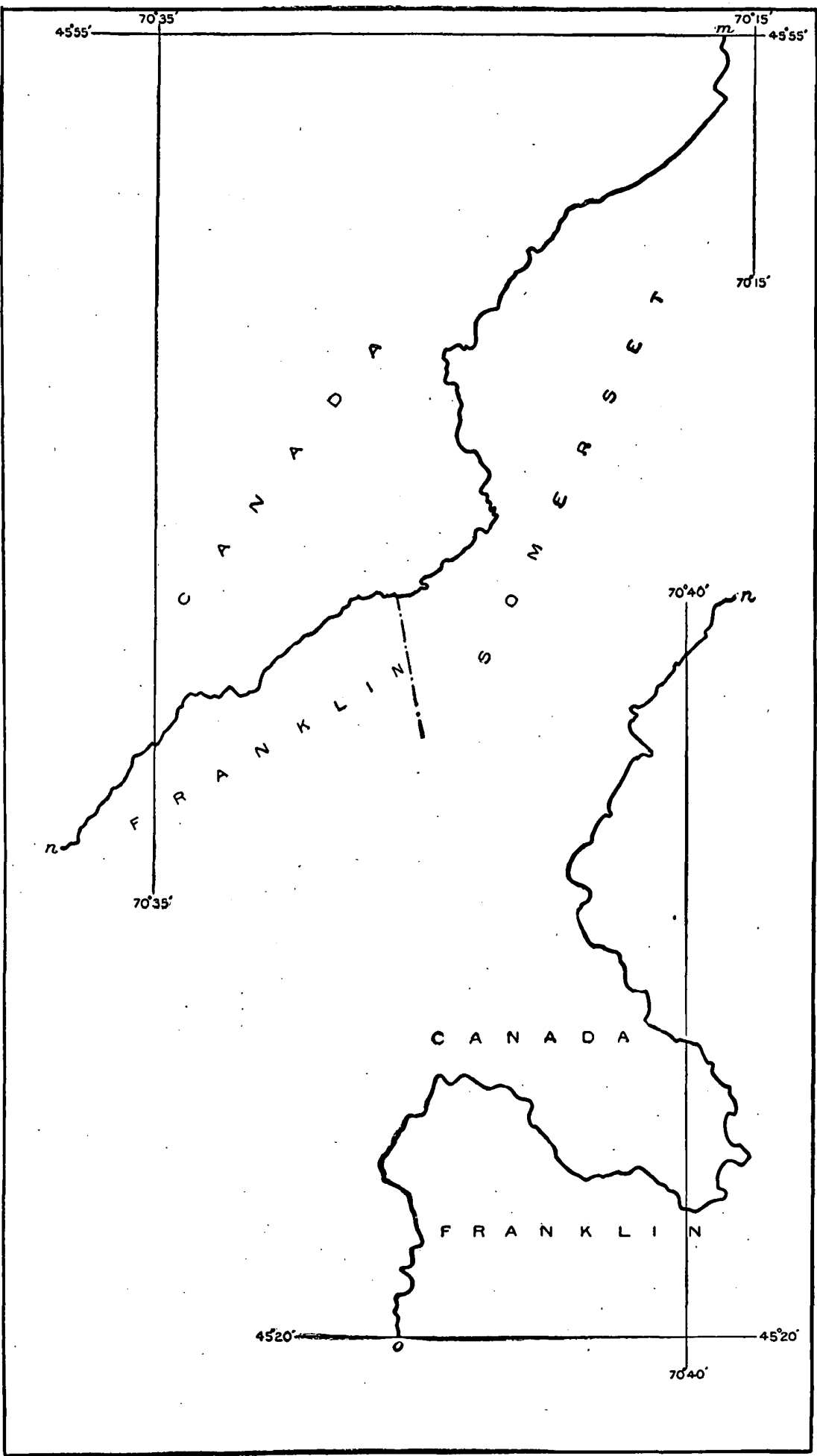

BOUNDARY BETWEEN MAINE AND CANADA. 
U. 8. GEOLOGICAL BURVEY

BULLETIN NO. 228 PL. XIII

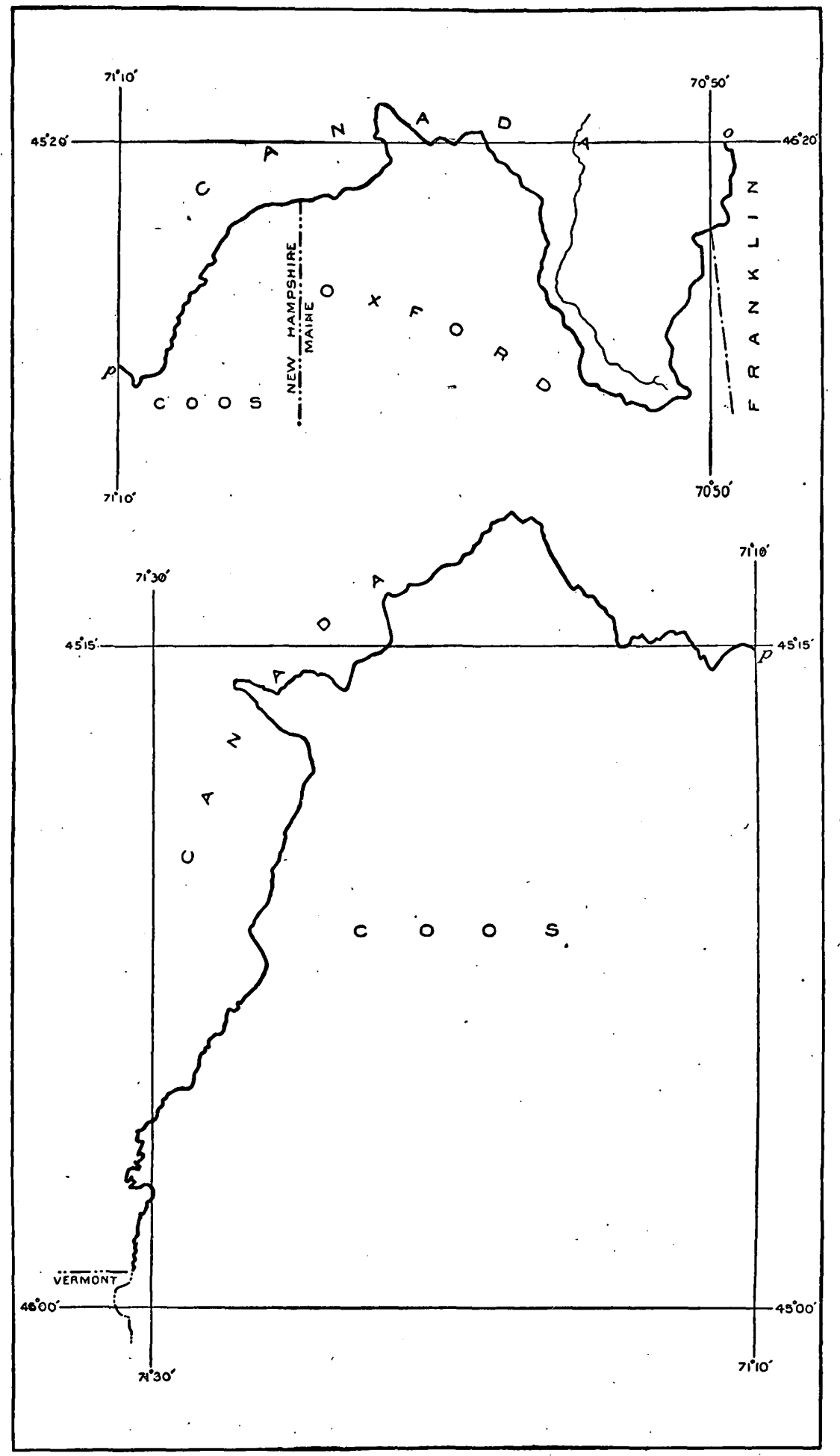

BOUNDARY BETWEEN MAINE, NEW HAMPSHIRE, AND CANADA. 
Werster-Ashburton Treaty with Grea't Britain, 1846.

Article I. From the point on the forty-ninth parallel of north latitude, where the boundary laid down in existing treaties and conventions between the United States and Great Britain terminates, the line of boundary between the territories of the United States and those of Her Britannic Majesty shall be continued westward along the said forty-ninth parallel of north latitude to the middle of the channel which separates the continent from Vancouver's Island, and thence southerly through the middle of the said channel, and of Fuca's Straits to the Pacific Ocean: Provided, however, That the navigation of the whole of the said channel and straits south of the forty-ninth parallel of north latitude remain free and open to both parties.

AR'TICLE II. From the point at which the forty-ninth parallel of north latitude shall be found to intersect the great northern branch of the Columbia River, the navigation of the said branch shall be free and open to the Hudson's Bay Company, and to all British subjects trading with the same, to the point where the said branch meets the main stream of the Columbia, and thence down the said main stream to the ocean, with free access into and through the said river or rivers, it being understood that all the usual portages along the line thus described shall, in like manner, be free and open. In navigating the said river, or rivers, British subjects, with their goods and produce, shall be treated on the same-footing as citizens of the United States; it being, however, always understood that nothing in this article shall be construed as preventing, or intending to prevent, the Government of the United States from making any regulations respecting the navigation of the said river or rivers not inconsistent with the present treaty.

The above treaty extended the line westward from the Rocky Mountains to the Pacific along the forty-ninth parallel of latitude. This settled the northern boundary with the exception of the islands and passages in the straits of Georgia and of Juan de Fuca, the English claiming that the boundary should properly run through the Rosario Strait, the most eastern passage, while the United States claimed that it should naturally follow the Strait of Haro.

This matter was finally settled by a reference to the Emperor of Germany as an arbitrator, who decided it in favor of the United States on the 21st of October, 1872, thus finally disposing of our boundary with Great Britain.

\section{ADDITIONS TO THE TERRITORY OF THE UNITED STATES.}

IOUISIANA PURCHASE.

The entire basin of the Mississippi, with much of the coast region of the Gulf of Mexico, which was subsequently known as the territory of Louisiana, was originally claimed by France by virtue of discovery and, occupation.

In 1712 France made a grant to Antoine de Crozat. of the exclusive right to the trade of this region. As this grant makes the first, and, indeed, the only statement of the limits of this vast region, as they were understood by France, a portion of it is here introduced.

We have by these presents signed with our hand, authorized, and do authorize the said Sieur Crozat to carry on exclusively the trade in all the territories by us 
possessed, and bounded by New Mexico and by those of the English in Carolina, all the establishments, ports, harbors, rivers, and especially the port and harbor of Dauphin Island, formerly called Massacre Island, the river St. Louis, formerly called the Mississippi, from the seashore to the Illinois, together with the river St. Philip, formerly called the Missouries River, and the St. Jerome, formerly called the Wabash (the Ohio), with all the countries, territories, lakes in the land, and the rivers emptying directly or indirectly into that part of the river St. Louis. All the said territories, countries, rivers, streams, and islands we will to be and remain comprised under the name of the government of Louisiana, which shall be dependent on the General Government of New France and remain subordinate to it, and we will, moreover, that all the territories which we possess on this side of the Illinois be united, as far as need be, to the General Government of New France and form a part thereof, reserving to ourself, nevertheless, to increase, if we judge proper, the extent of the government of the said country of Louisiana.

From this it appears that Louisiana was regarded by France as comprising the drainage basin of the Mississippi at least as far north as the mouth of the Illinois, with those of all its branches which enter it below this point, including the Missouri, but excluding that portion in the southwest claimed by Spain. It is, moreover, certain that the area now comprised in Washington, Oregon, and Idaho was. not included.

Crozat surrendered this grant in 1717 .

On November 3, 1762, France ceded this region to Spain, defining it only as the province of Louisiana. A few months later, on February 10,1763 , by the treaty of peace between Great Britain, France, and Spain, the western boundary of the former's possessions in the New World was placed in the center of the Mississippi River, thus reducing the area of Louisiana by the portion east of the Mississippi River. Thus by these two treaties France disposed of her possessions in North America, dividing them between Great Britain and Spain. The limit set between their possessions was given as the Mississippi, the river Iberville, and lakes Maurepas and Pontchartrain.

Great Britain then proceeded to subdivide her share of this territory. The area south of a meridian through the mouth of Yazoo River and west of Apalachicola River she called West Florida; the region east thereof and south of the present north boundary of Florida received the name of East Florida. For the following twenty years, i. e., up to 1783 , these boundaries and names remained undisturbed. In the latter year, by the treaty of peace with the United States at the close of the Revolution, Great Britain reduced the area of West Florida by the cession of that portion north of the thirty-first parallel to the United States. In the same year she gave East Florida and what remained of West Florida to Spain, and in Spain's possession they remained until ceded to the United States in 1819.

Meantime, in 1800 , by the secret treaty of San Ildefonso, Spain promised to return Louisiana to France. In the language of the treaty, she pledged herself to return to France the "Province of Louisiana, with the same extent it now has in the hands of Spain, and 


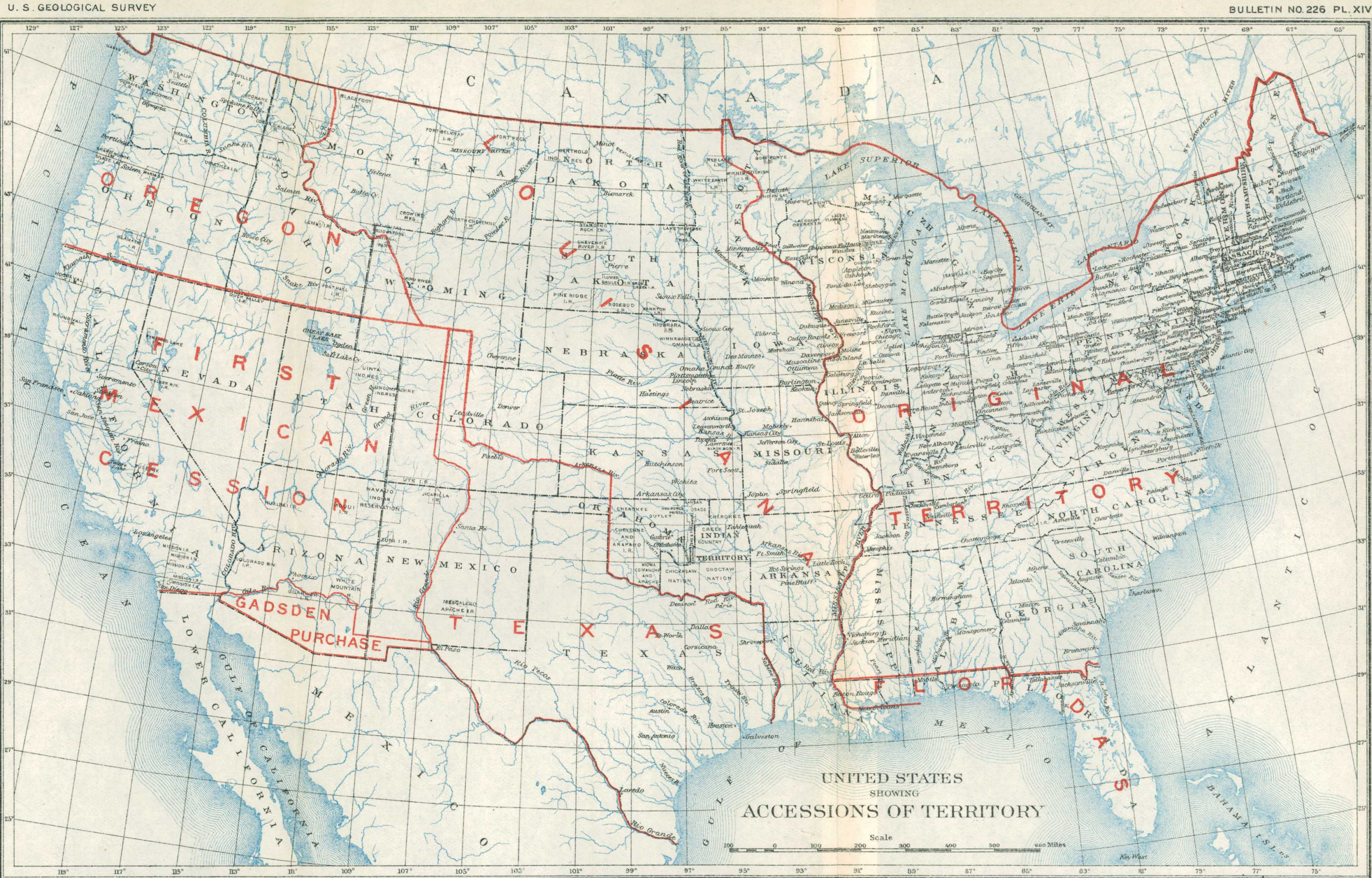


that it had when Spain possessed it, and such as it should be after the treaties subsequently entered into between Spain and other States."

Immediately after this transfer became known, on November 30 , 1802, measures were set on foot by President Jefferson for securing in some way free access to the sea by way of the Mississippi River. Circumstances favored this negotiation. Bonaparte was at that time in almost daily expectation of a declaration of war by Great Britain, in which case the first act of the latter would be to seize the mouth of the Mississippi, and with it the province of Louisiana. Under these circumstances Bonaparte offered to sell the province to the United States, and the offer was promptly accepted. The consideration was $60,000,000$ francs and the assumption by the United States of the "French spoliation claims," which were estimated to amount to $\$ 3,750,000$.

The treaty of cession, which bears date April 30, 1803, describes the territory only as being the same as ceded by Spain to France by the treaty of San Ildefonso.

From this it appears that the territory sold to the United States comprised that part of the drainage basin of the Mississippi which lies west of the course of the river, with the exception of such parts as were then held by Spain. The want of precise definition of limits in the treaty was not objected to by the American commissioners, as they probably foresaw that this very indefiniteness might prove of service to the United States in future negotiations with other powers. In fact, the claim of the United States to the area now comprised in Oregon, Washington, and Idaho in the negotiations with Great Britain regarding the northwestern boundary was ostensibly based not only upon prior occupation and upon purchase from Spain, but also upon the alleged fact that this area formed part of the Louisiana purchase. That this claim was baseless is shown not only by what has been already detailed regarding the limits of the purchase, but also by the direct testimony of the French plenipotentiary, M. Barbé Marbois. Some twenty years after the purchase he published a work upon Louisiana, in which he detailed at some length the negotiations which preceded the purchase, and, referring to this question, said: "The shores of the western ocean were certainly not comprised in the cession, but already the United States are established there."

There is also contained in this work a map of the country between the Mississippi and the Pacific, on which the extent of Louisiana to the westward is indicated by a line drawn on the one hundred and tenth meridian, which is not far from the western limit of the drainage basin of the Mississippi in Wyoming and Montana. That part of the country now comprised in Oregon, Washington, and Idaho, which, it has been claimed, formed part of the purchase, bears the following legend: "Territories and countries occupied by the United States, following the treaty of cession of Louisiana." 
From this it appears that the northwestern limits of the Louisiana purchase can no longer be a matter of discussion; but although the United States certainly did not purchase Oregon as a part of Louisiana, it is no less certain that that great area west of the Rocky Mountains fell into their hands as a direct consequence of such purchase.

\section{FLoRida PURchase.}

The second addition to the territory of the United States consisted of the Floridas, purchased from Spain on February 22, 1819. From the date of the Louisiana purchase, in 1803, the territory bounded by the Mississippi River on the west, the Perdido on the east, the parallel of $31^{\circ}$ on the north, and the Gulf on the south had been in dispute between the two countries. During a part of this time it had been practically in the possession of the United States.

The clause quoted above from the treaty of San Ildefonso was interpreted by Jefferson and others in this country to mean the inclusion of West Florida. Their reasoning was this: In 1800 Spain owned West Florida; West Florida was once a part of Louisiana; in 1800 Spain receded Louisiana to France; she therefore receded West Florida with it.

Spain, however, held that this was merely a treaty of recession, by which she gave back to France what France had given to her in 1762. Since in 1762 she did not own West Florida, she could not, therefore, have receded it to France.

As to this matter, Marbois, the French plenipotentiary, was very positive in stating that West Florida formed no part of the Louisiana purchase, and that the southeastern boundary of the latter was the river Iberville and Lakes Maurepas and Pontchartrain.

Immediately after the Louisiana purchase the claim was made by the United States that it included most of West Florida, and also a part of the Texas coast, but this was not entertained by Spain. In 1810 a revolution was effected in that part of West Florida lying west of Pearl River, and application was made for annexation to the United States. The governor of Louisiana, under instructions from Washington, at once took possession, but immediately a counter revolution was organized against him, which was put down by force of arms, and in 1812 this part of West Florida was annexed to the State of Louisiana. Meantime, the insurrection spread eastward in West Florida, and, although put down by Spanish authorities, the movement received the sympathy of the United States, which passed a secret act authorizing the President, under certain specified contingencies, to use force in taking possession of the Floridas. In 1812 that portion of West Florida lying between Perdido and Pearl rivers was annexed to the Territory of Mississippi.

This purchase settled these conflicting claims. 
The following is the clause in the treaty with Spain ceding the Floridas which defines the cession:

ArT. 2. His Catholic Majesty cedes to the United States, in full property and sovereignty, all the territories which belong to him, situated to the eastward of the Mississippi, known by the name of East and West Florida, the adjacent islands dependent upon said province, etc.

A further article in this treaty defines the boundary between the United States and the Spanish possessions in the Southwest as follows:

The boundary line between the two countries, west of the Mississippi, shall begin on the Gulf of Mexico, at the mouth of the river Sabine, in the sea, continuing north, along the western bank of that river, to the thirty-second degree of latitude, thence by a line due north to the degree of latitude where it strikes the Rio Roxo of Nachitoches, or Red River; then following the course of the Rio Roxo to the degree of longitude 100 west from London, or about $23^{\circ}$ west of Washington; then crossing the said Rio Roxo and running thence, by a line due north, to the river Arkansas; thence, following the course of the southern bank of the Arkansas, to its source in latitude 42 north; and thence by that parallel of latitude to the South Sea, the whole being as laid down in Melish's map of the United States, published at Philadelphia, improved to the 1st of January, 1818. But if the source of the Arkansas River shall be found to fall north or south of latitude 42 , then the line shall run from the said source due south or north, as the case may be, till it meets the said parallel of latitude 42, and thence along the said parallel to the South Sea, all the islands in the Sabine and the said Red and Arkansas rivers, throughout the course thus described, to belong to the United States; but the use of the waters, and the navigation of the Sabine to the sea, and of the said rivers Roxo and Arkansas throughout the extent of the said boundary on their respective banks shall be common to the respective inhabitants of both nations.

\section{TEXAS ACCESSION.}

The next acquisition of territory was that of the Republic of Texas, which was admitted as a State on December 29, 1845. The area which Texas brought into the Union was limited as follows, as defined by the Republic of Texas, December 19, 1836:

Beginning at the mouth of the Sabine River and running west along the Gulf of Mexico three leagues from land to the mouth of the Rio Grande, thence up the principal stream of that river to its source, thence due north to the forty-second degree of north latitude, thence along the boundary line as defined in the treaty between Spain and the United States to the beginning.

\section{FIRST MEXICAN CESSION.}

In 1848 a further addition was made to our territory by the treaty of Guadalupe-Hidalgo. This added to the country the area of California, Nevada, Utah, and parts of Colorado, Arizona, and New Mexico, while the Gadsden purchase, which was effected in 1853, added the remainder of Arizona and another part of New Mexico.

The treaty of Guadalupe-Hidalgo was concluded February 2, 1848, and proclaimed July 4, 1848. The clauses in it defining our acquisition of territory are as follows:

Article V. The boundary line between the two Republics shall commence in the Gulf of Mexico, three leagues from land, opposite the mouth of the Rio Grande, Bull. $226-04-4$ 
otherwise called the Rio Bravo del Norte, or opposite the mouth of its deepest branch, if it should have more than one branch emptying into the sea; from thence up the middle of that river, following the deepest channel where it has more than one, to the point where it strikes the southern boundary of New Mexico; thence westwardly along the whole southern boundary of New Mexico (which runs north of the town called Paso) to its western termination; thence northward along the western line of New Mexico until it intersects the first branch of the river Gila (or if it should not intersect any branch of that river, then to the point on the said line nearest to such branch, and thence in a direct line to the same); thence down the middle of the said branch and of the said river until it empties into the Rio Colorado; thence across the Rio Colorado, following the division line between Üpper and Lower California, to the Pacific Ocean.

The southern and western limits of New Mexico, mentioned in this article, are those laid down in the map entitled "Map of the United Mexican States as organized and defined by various acts of the Congress of said Republic, and constructed according to the best authorities. Revised edition. Published at New York in 1847, by J. Disturnell;" of which map a copy is added to this treaty, bearing the signatures and seals of the undersigned plenipotentiaries. And in order to preclude all difficulty in tracing upon the.ground the limit separating Upper from Lower California, it is agreed that the said limit shall consist of a straight line drawn from the middle of the Rio Gila, where it unites with the Colorado, to a point on the coast of the Pacific Ocean, distant one marine leagne due south of the southernmost point of the port of San Diego, according to the plan of said port made in the year 1.782 by Don Juan Pautoja; second sailing master of the spanish fleet, and published at Madrid in the year 1802, in the atlas to the voyage of the schooners Sutil and Mexicana; of which plan a copy is hereunto added, signed, and sealed by the respective plenipotentiaries.

Much difficulty followed in the interpretation of this treaty. A joint commission of the two Governments was formed, consisting of a commissioner and a chief surveyor from each. They were instructed that any decision upon the interpretation of the treaty must be agreed to unanimously. The most important question coming before the commission for decision concerned the location and extent of the south boundary of New Mexico. Here, unfortunately, the Disturnell map left room for broad difference in opinion. The town called Paso is incorrectly located upon the map to the extent of nearly half a degree of latitude, or, in other words, the parallels of latitude are misplaced to this extent, so that if the position of the south boundary of New Mexico be accepted with reference to the nearest parallel of latitude, it is half a degree farther north than it would be if its position were measured from the town of Paso.

In the absence of the chief surveyor the other three members of the commission, including Mr. J. R. Bartlett, United States commissioner, agreed to accept the position of the south boundary of New Mexico as shown by the projection lines of the map; to run a line in this latitude 3 degrees west from the Rio Grande, and from the end of this line to run north until a branch of Gila River was intersected. In accordance with this decision a durable monument was erected on the bank of the Rio Grande, in latitude $32^{\circ} 22^{\prime}$, and the line was run a degree and a balf to the westward. At this time the chief surveyor arrived, 
learned what had been done, and made a vigorous protest against this interpretation of the map. This protest, backed by Major Emory, the chief astronomer, caused a sudden stoppage of the work of running the line and the repudiation of the agreement by the United States Government. Negotiations followed, but no agreement was reached until in 1853 the whole matter was taken out of court by the Gadsden purchase.

\section{GADSDEN PURCHASE.}

Subsequently, on December 30,1853, a second purchase was made of Mexico, consisting of the strip of land lying south of the Gila River in New Mexico and Arizona. The boundaries as established by this, known as the Gadsden purchase, were as follows:

Artrcle I. The Mexican Republic agrees to designate the following as her true limits with the United States for the future: Retaining the same dividing line between the two Californias as already defined and established according to the fifth article of the treaty of Guadalupe-Hidalgo, the limits between the two Republics shall be as follows: Beginning in the Gulf of Mexico, three leagues from land, opposite the month of the Rio Grande, as provided in the fifth article of the treaty of GuadalupeHidalgo; thence, as defined in the said article, up the middle of that river to the point where the parallel of $31^{\circ} 47^{\prime}$ north latitude crosses the same; thence due west one hundred miles; thence south to the parallel of $31^{\circ} 20^{\prime}$ north latitude; thence along the said parallel of $31^{\circ} 20^{\prime}$ to the one hundred and eleventh meridian of longitude west of Greenwich; thence in a straight line to a point on the Colorado River twenty English miles below the junction of the Gila and Colorado rivers; thence up the middle of the said river Colorado until it intersects the present line between the United States and Mexico.

In the year following a commission was appointed for surveying and marking this line, under the United States commissioner, Maj. W. H. Emory. The line was run and marked in the year 1855, and the report was transmitted in the following year.

As settlement increased in the territory which this line traverses, the fact was developed that the line was insufficiently marked. Some of the monuments had disappeared, and in many places there were great extents of country in which no monuments had ever been placed, so that the necessity became apparent for rerunning and marking of the line. For this purpose a commission was created in 1891, the United States members of which were Col. J. W. Barlow and Capt. D. D. Gaillard, Corps of Engineers, U. S. A., and Mr. A. T. Mosman, of the United States Coast and Geodetic Survey. Under this commission the line was recovered from the original monuments as far as possible, and between these monuments was rerun and fully and durably marked. The report, with maps, profiles, and illustrations of the monuments, was published in 1899 .

\section{ALASKA PURCHASE.}

Alaska was purchased from Russia, the treaty of purchase having been signed on March 30, 1867, and proclaimed June 20, 1867. The 
boundaries of the territory are described in the accompanying quotation from the treaty:

Commencing from the southernmost point of the island called Prince of Wales Island, which point lies in the parallel of $54^{\circ} 40^{\prime \prime}$ north latitude, and between the one hundred and thirty-first and one hundred and thirty-third degree of west longitude (meridian of Greenwich), the said line shall ascend to the north along the channel called Portland Channel as far as the point of the continent where it strikes the fifty-sixth degree of north latitude; from this last-mentioned point the line of demarcation shall follow the summit of the mountains situated parallel to the coast as far as the point of intersection of the one hundred and forty-first degree of west longitude (of the same meridian); and, finally, from the said point of intersection the said meridian line of the one hundred and forty-first degree in its prolongation as far as the Frozen Ocean.

IV. With reference to the line of demarcation laid down in the preceding article it is understood-

1st. That the island called Prince of Wales Island shall belong wholly to Russia (now, by this cession, to the United States).

$2 \mathrm{~d}$. That whenever the summit of the mountains which extend in a direction parallel to the coast from the fifty-sixth degree of north latitude to the point of intersection of the one hundred and forty-first degree of west longitude shall prove to be at the distance of more than ten marine leagues from the ocean, the limit between the British Possessions and the line of coast which is to belong to Russia, as above mentioned (that is to say, the limit to the possessions ceded by this convention), shall be formed by a line parallel to the winding of the coast, and which shall never exceed the distance of ten marine leagues therefrom.

The western limit within which the territories and dominion conveyed are contained passes through a point in Behring's Straits on the parallel of $65^{\circ} 30^{\prime}$ north latitude at its intersection by the meridian which passes midway between the islands of Krusenstern or Ignalook and the island of Ratmanoff or Noonerbook, and proceeds due north without limitation into the same Frozen Ocean.

The same western limit, beginning at the same initial point, proceeds thence in a course nearly southwest through Behring's Straits and Behring's Sea, so as to pass midway between the northwest point of the island of Saint Lawrence and the southeast point of Cape Cboukotski to the meridian of one hundred and seventy-two west longitude; thence from the intersection of that meridian in a southwesterly direction, so as to pass midway between the island of Attore and the Copper Island of the Kormandorski couplet or group, in the North Pacific Ocean, to the meridian of one hundred and ninety-three degrees west longitude, so as to include in the territory conveyed the whole of the Aleutian Islands west of that meridian.

The consideration paid for Alaska was $\$ 7,200,000$ in gold.

There is no possibility of a misinterpretation of the language of the above treaty concerning the portion of the boundary running along the one bundred and forty-first meridian from the shores of the Arctic Ocean to the neighborhood of the coast near Mount St. Elias, and in recent years points upon this boundary, notably at the crossing of the Yukon, have been established by the United States and Canadian surveyors by astronomic means and marked.

Concerning the remaining portion of the boundary, however, from the neighborhood of Mount St. Elias southeastward to the mouth of Portland Canal, question has been raised in recent years by Canadian authorities. 


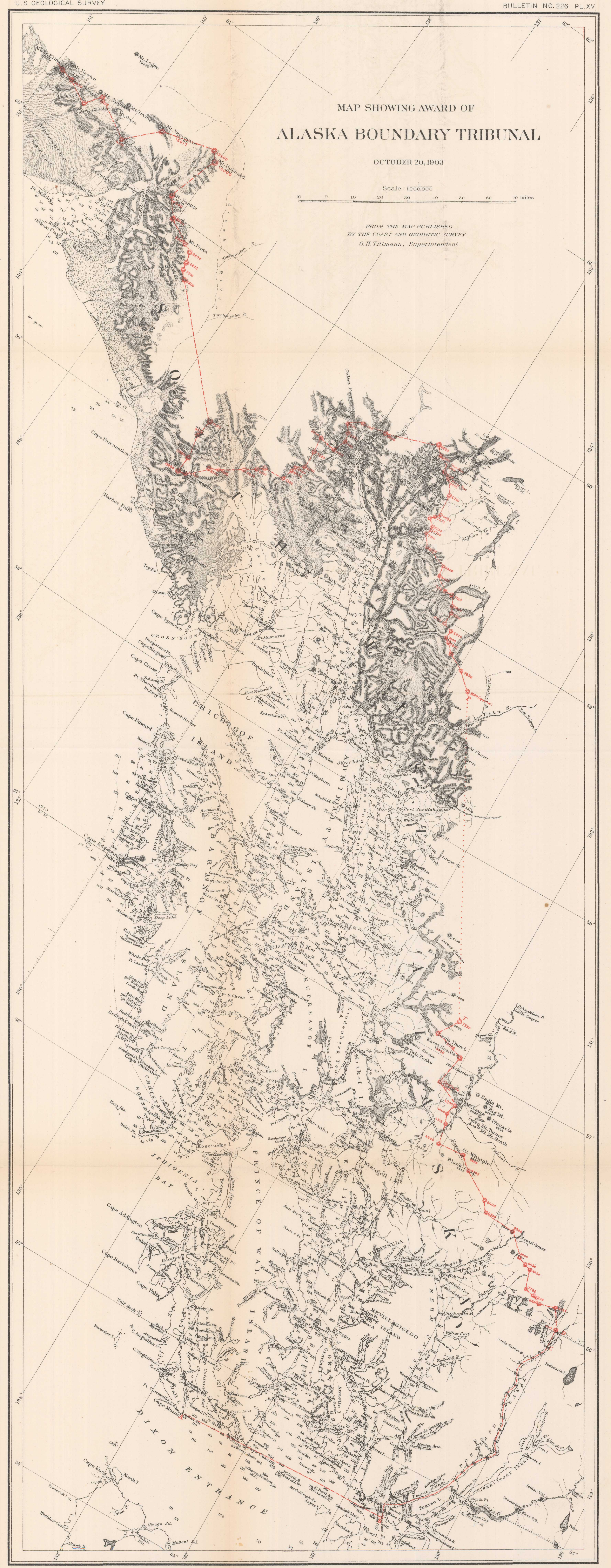


It has long been known that the coast of this part of Alaska is extremely broken, containing many fiords extending far inland, and that no continuous range of mountains parallels the coast. . It was for many years tacitly admitted by both sides that the second alternative of the treaty, that the boundary should follow a line 10 marine leagues distant from the coast and following its windings, should be the one finally adopted when the question of marking the boundary arose. This position was taken by the United States and consistently followed from the time of the acquisition of the territory to the present. All maps, United States and Canadian, agreed on it. Many acts of sovereignty were performed by the United States within this territory, no question being raised by the Canadian authorities, and the claim of the United States to a strip of territory 10 marine leagues in width from the main coast was universally admitted by the Canadian authorities. The discovery of gold in the basin of the Yukon, in Canada, and the fact that the only feasible means of access to this region lay through United States territory, made it extremely desirable for Canada to possess a port or ports on this coast as the starting points of routes to the Yukon mines, and it was only when this necessity appeared that any question arose concerning the interpretation of the definition of limits in the treaty.

The claim made by the British Government, before a joint commission on the boundary, on behalf of Canada, in August, 1898, was that this portion of the boundary, instead of passing up Portland Canal, should pass up Pearse Canal, connecting with Portland Canal, up which it follows to the summit of the mountains nearest to the coast, and then should follow them, regardless of the fact that they do not form a continuous range, crossing all the inlets of the sea up to Mount St. Elias. This, of course, was refused by the United States commissioners. A proposition made by the British commissioners to refer the matter to arbitration was also refused by the United States commissioners, on the ground that there was nothing to arbitrate, since the territory in question was in the possession of the United States, and had been for many years without dispute, such possession being in full accord with the terms of the treaty. The commission was then dissolved, the only outcome being an agreement that the summits of White and Chilkoot passes and a point upon the Chilkat, above Pyramid Harbor, were temporarily adopted as points upon the boundary.

The treaty of January 24, 1903, created an Alaskan Boundary Tribunal, to consist of "six impartial jurists of repute," three to be selected by each of the two parties to the controversy, to attempt a settlement of this boundary question. The United States was represented by Messrs. Elihu Root, Henry Cabot Lodge, and George Turner. The Canadian side was represented by Baron Alverstone, lord chief justice of England, Sir Louis A. Jetté, and A. B. Aylesworth, of 
Canada. After argument and discussion the majority of the tribunal, consisting of Baron Alverstone and the three Americans, agreed on a boundary which satisfied the American claims. The boundary thus adopted may be defined as follows: Its commencement is at Cape Muzon. Then it crosses in a straight line to the mouth of Portland Chunnel, this entrance being to the west of Wales Island, and thence passes up the channel to the north of Wales and Pearse islands, to the fifty-sixth parallel of latitude. 'Thence the line runs from one mountain summit to another, as shown on the accompanying map (Pl. XV), passing above the heads of all fiords. At the head of Lynn Canal it traverses White and Chilkoot passes. Then by a crooked southwesterly course it reaches Mount Fairweather, and thence follows the higher mountains around Yakutat Bay to Mount St. Elias. It can be clearly described only by a map.

\section{HAWAIIAN ISTANDS.}

The Republic of Hawaii, comprising eight inhabited and seven uninhabited islands in the Pacific, voluntarily joined the United States in 1898.

porto Rico, Guar, aNi PHILIPPINE ISLANDS.

The next accessions of territory made by the United States were the islands taken from Spain following the war of 1898. These were relinquished to the United States by the treaty of peace of December 10, 1898. They were as follows:

Porto Rico and other Spanish West India islands which were ceded to the United States.

The island of Guam, in the Ladrones.

The Philippine Islands, which comprise all the islands lying within the following line, as defined in the words of the treaty:

A line running from west to east along or near the twentieth parallel of north latitude, and through the middle of the navigable channel of Bachi, from the one hundred and eighteenth (118th) to the one hundred and twenty-seventh (127th) degree meridian of longitude east of Greenwich; thence along the one.hundred and twenty-seventh (127th) degree meridian of longitude east of Greenwich to the parallel of four degrees and forty-five minutes $\left(4^{\circ} 45^{\prime}\right)$ north latitude; thence along the parallel of four degrees and forty-five minutes $\left(4^{\circ} 45^{\prime}\right)$ north latitude to its intersection with the meridian of longitude one hundred and nineteen degrees and thirtyfive minutes $\left(119^{\circ} 35^{\prime}\right)$ east of Greenwich; thence along the meridian of longitude one hundred and nineteen degrees and thirty-five minutes $\left(119^{\circ} 35^{\prime}\right)$ east of Greenwich to the parallel of latitude seven degrees and forty minutes $\left(7^{\circ} 40^{\prime}\right)$ north; thence along the paralled of latitude seven degrees and forty minutes $\left(7^{\circ} 40^{\circ}\right)$ north to its intersection with the one hundred and sixteenth (116th) degree meridian of longitude east of Greenwich; thence by a direct line to the intersection of the tenth (10th) degree parallel of north latitude with the one hundred and eighteenth (118th) degree meridian of longitude east of Greenwich; and thence along the one hundred and eighteenth (118th) degree meridian of longitude east of Greenwich to the point of beginning. 
For the Philippines the sum of $\$ 20,000,000$ was paid by the United States to Spain.

Subsequently the United States purchased of Spain, for the sum of $\$ 100,000$, a small group of islands lying north of Borneo, known as Cagayan Jolo, which, though a part of the Philippine Archipelago, was omitted by mistake in drawing the limits of the Philippines in the treaty.

TUTUILA.

For several years the United States, Great Britain, and Germany exercised a joint protectorate over the Samoas. For various reasons it was deemed best to bring this situation to an end. England withdrew and the islands were divided between Germany and the United States, the latter country taking Tutuila and the other small islands of that group lying east of longitude $171^{\circ}$ west of Greenwich and the German flag being hoisted over the remaining islands of the group. This adjustment was reached February 16, 1900. 
THE PUBLIC DOMAIN AND AN OUTLINE OF THE HISTORY OF CHANGES MADE THEREIN.

CESSIONS BY THE STATES.

At the time the Constitution was adopted by the original thirteen States, many of them possessed unoccupied territory, in some cases entirely detached and lying west of the Appalachian.Mountains. Thus, Georgia included the territory from its present eastern limits westward to the Mississippi River. North Carolina possessed a narrow strip extending from latitude $35^{\circ}$ to $36^{\circ} 30^{\prime}$, approximately, and running westward to the Mississippi, including besides its own present area that of the present State of Tennessee. In like manner, Virginia possessed what is now Kentucky, while a number of States, as Pennsylvania, New York, Massachusetts, and Connecticut, laid claim to areas in what was afterwards known as the Territory Northwest of the River Ohio, a region which is now comprised mainly in the States of Ohio, Indiana, Illinois, Michigan, and Wisconsin. These claims were to a greater or less extent conflicting. In some cases several States claimed authority over the same area, while the boundary lines were in most cases very ill-defined.

The ownership of these western lands by individual States was opposed by those States which did not share in their possession, mainly on the ground that the resources of the General Government, to which all contributed, should not be taxed for the protection and development of this region, while its advantages would inure to the benefit of but a favored few. On this ground several of the States refused to ratify the Constitution until this matter had been settled by the cession of these tracts to the General Government.

Moved by these arguments, as well as by the consideration of the conflicting character of the claims, which must inevitably lead to trouble among the States, Congress passed, on October 30, 1779, the following act:

Whereas the appropriation of the vacant lands by the several States during the present war will, in the opinion of Congress, be attended with great mischiefs: - Therefore,

Resolved, That it be earnestly recommended to the State of Virginia to reconsider their late act of assembly for opening their land office; and that it be recommended to the said State, and all other States similarly circumstanced, to forbear settling or issuing warrants for unappropriated lands, or granting the same during the continuance of the present war. 
This resolution was transmitted to the different States. The first to respond to it by the transfer of her territory to the General Government was New York, whose example was followed by the other States.

The cessions were made on the dates given below:

New York, March 1, 1781.

Virginia, March 1, 1784.

Massachusetts, April 19, 1785.

Connecticut, September 13, 1786.

The Connecticut act of cession reserved an area in the northeastern part of Ohio, known as the Western Reserve. On May 30, 1800, Connecticut gave to the United States jurisdiction over this area, but without giving up its property rights in it.

South Carolina, August 9, 1787.

North Carolina, February 25, 1790.

Georgia, April 24, 1802.

The following paragraph from the deed of cession by New York defines the limits of its cession to the General Government:

Now, therefore, know ye, that we, the said James Duane, William Floid, and Alexander M'Dougall, by virtue of the power and authority, and in the execution of the trust reposed in us, as aforesaid, have judged it expedient to limit and restrict, and we do, by these presents, for and in behalf of the said State of New York, limit and restrict the boundaries of the said State in the western parts thereof, with respect to the jurisdiction, as well as the right or pre-emption of soil, by the lines and in the form following, that is to say: A line from the northeast corner of the State of Pennsylvania, along the north bounds thereof to its northwest corner, continued due west until it shall be intersected by a meridian line to be drawn from the forty-fifth degree of north latitude, through the most westerly bent or inclination of Lake Ontario; thence by the said meridian line to the forty-fifth degree of north latitude; and thence by the said forty-fifth degree of north latitude; but, if on experiment, the above-described meridian line shall not comprehend twenty miles due west from the most westerly bent or inclination of the river or strait of Niagara, then we do, by these presents, in the name of the people, and for and on behalf of the State of New York, and by virtue of the authority aforesaid, limit and restrict the boundaries of the said State in the western parts thereof, with respect to jurisdiction, as well as the right of pre-emption of soil, by the lines and in the manner following, that is to say: A line from the northeast corner of the State of Pennsylvania, along the north bounds thereof, to its northwest corner continued due west until it shall be intersected by a meridian line, to be drawn from the forty-fifth degree of north latitude, through a point twenty miles due west from the most westerly bent or inclination of the river or strait Niagara; thence by the said meridian line to the forty-fifth degree of north latitude, and thence by the said forty-fifth degree of north latitude.

The deed of cession by Virginia gives nolimits, further than to specify that the lands transferred include only those lying northwest of the river Ohio.

The following paragraph from the deed of cession by Massachusetts gives the limits of the area ceded:

* * * We do by these presents assign, transfer, quitclaim, cede, and convey to the United States of America, for their benefit, Massachusetts inclusive, all right, 
title, and estate of and in, as well the soil as the jurisdiction, which the said Commonwealth hath to the territory or tract of country within the limits of Massachusetts charter situate and lying west of the following line, that is to say, a meridian line to be drawn from the forty-fifth degree of north latitude through the westerly bent or inclination of Lake Ontario, thence by the said meridian line to the most southerly side line of the territory contained in the Massachusetts charter; but if on experiment the above-described meridian line shall not comprehend twenty miles due west from the most westerly bent or inclination of the river or strait of Niagara, then we do by these presents, by virtue of the power and authority aforesaid, in the name and on behalf of the said Commonwealth of Massachusetts, transfer, quitclaim, cede, and convey to the United States of America, for their benefit, Massachusetts inclusive, all right, title, and estate of and in as well the soil as the jurisdiction, which the said Commonwealth hath to the territory or tract of country within the limits of the Massachusetts charter, situate and lying west of the following line, that is to say, a meridian line to be drawn from the forty-fifth degree of north latitude through a point twenty miles due west from the most westerly bent or inclination of the river or strait of Niagara; thence by the said meridian line to the most southerly side line of the territory contained in the Massachusetts charter aforesaid.

The following clause from the act of the legislature of Connecticut, authorizing the cession, defines its limits:

Be it enacted *** That the delegates of this State, or any two of them, who shall be attending the Congress of the United States, be, and they are hereby, directed, authorized, and fully empowered, in the name and behalf of this State, to make, execute, and deliver, under their hands and seals, an ample deed of release and cession of all the right, title, interest, jurisdiction, and claim of the State of Connecticut to certain western lands, beginning at the completion of the forty-first degree of north latitude, one hundred and twenty miles west of the western boundary line of the Commonwealth of Pennsylvania, as now claimed by said Commonwealth, and from thence by a line drawn north, parallel to and one hundred and twenty miles west of the said west line of Pennsylvania, and to continue north until it comes to forty-two degrees and two minutes north latitude. Whereby all the right, title, interest, jurisdiction, and claim of the State of Connecticut to the lands lying west of said line to bedrawn as aforementioned, one hundred and twenty miles west of the western boundary line of the Commonwealth of Pennsylvania, as now claimed by said Commonwealth, shall be included, released, and ceded to the United States in Congress assembled, for the common use and benefit of the said States, Connecticut inclusive.

\section{The cession of South Carolina was described as follows:}

* * All the territory or tract of country included within the river Mississippi and a line beginning at that part of the said river which is intersected by the southern boundary line of the State of North Carolina, and continuing along the said boundary line until it intersects the ridge or chain of mountains which divides the eastern from the western waters, then to be continued along the top of said ridge of mountains until it intersects a line to be drawn due west from the head of the southern branch of Tugaloo River to the said mountains; from thence to run a due west course to the river Mississippi.

\section{The State of North Carolina ceded-}

The lands situated within the chartered limits of the State, west of a line beginning on the extreme height of Stone Mountain, at the place where the Virginia line intersects it; running thence along the extreme height of the said mountain to the place where the Watauga River breaks through it; thence a direct course to the top of the Yellow Mountain where Bright's road crosses the same; thence along the ridge of the said 
mountain, between the waters of Doe River and the waters of Rock Creek, to the place where the road crosses the Iron Mountain; from thence along the extreme height of the said mountain to where Nolechucky River runs through the same; thence to the top of the Bald Mountain; thence along the extreme height of the said mountain to the Painted Rock, on French Broad River; thence along the highest ridge of the said mountain to the place where it is called the Great Iron or Smoky Mountain; thence along the extreme height of the said mountain to the place where it is called the Unicoy or Unaka Mountain, between the Indian towns of Cowee and Old Chota; thence along the main ridge of the said mountain to the southern boundary of this State.

It will be noted that the above description of the eastern boundary of her ceded possessions agrees in general terms with the description of the western boundary of North Carolina, as given on page 102.

The articles of cession by Georgia describe the area ceded as follows:

The lands situated within the boundaries of the United States, south of the State of Tennessee and west of a line beginning on the west bank of the Chattahouchee River, where the same crosses the boundry line between the United States and Spain; thence running up the said river Chattahouchee and along the western bank thereof to the great bend thereof, next above the place where a certain creek or river, called Uchee (being the first considerable stream on the western side, above the Cussetas and Coweta towns), empties into the said Chattahouchee River; thence in a direct line to Nickajack, on the Tennessee River; thence crossing the last-mentioned river, and thence running up the said Tennessee River and along the western bank thereof to the southern boundary.line of the State of Tennessee.

Of the area thus ceded to the General Government the part lying north of the Ohio was afterwards erected into the "Territory Northwest of the River Ohio," and the balance, lying south of that river, was known as the "Territory South of the River Ohio."

\section{TERRITORY NORTHWEST OF THE RIVER OHIO.}

This territory was bounded on the west by the Mississippi and the international boundary, on the north by the boundary line between the United States and the British possessions, on the east by the Pennsylvania and New York State lines, and on the south by Ohio River. It comprised an area of, approximately, 266,000 square miles. It was made up of claims of different States, as follows:

1. Virginia uncontested claims, which consisted of all the territory west of Pennsylvania and north of the Ohio to the forty-first parallel of north latitude, besides her claim, by capture, as far as the northern limits of the land under the Crown which had been subject to the jurisdiction of the provinces of Quebec and to Lakes Michigan and Huron.

2. The claim of Connecticut, which extended from the forty-first parallel northward to the parallel of $42^{\circ} 2^{\prime}$, and from the west line of Pennsylvania to the Mississippi River.

3. The claim of Massachusetts, which extended from the north line of the Connecticut claim above noted to $43^{\circ} 43^{\prime} 12^{\prime \prime}$ north latitude, and from the eastern boundary of New York to the Mississippi. 
4. The belt or zone lying north of the Massachusetts claim, extending thence to the Canada line and west to the Mississippi River, was claimed to have been obtained by the treaty of peace of Great Britain, September 3, 1783.

5. At the cession by the State of Virginia, both Massachusetts and New York claimed the Erie purchase of about 316 square miles, which was subsequently bought by Pennsylvania and added to that State.

From this territory were formed the following States: Ohio, Indiana, Illinois, Michigan, Wisconsin, that part of Minnesota east of the Mississippi River, and the northwest corner of Pennsylvania.

In 1787 a bill for its provisional division into not less than three nor more than five States was passed by Congress. In this bill the limits of the proposed States were defined, corresponding in their north and south lines to the boundaries of Ohio, Illinois, and Indiana as at present constituted. The following gives the text of the clause defining these boundaries:

CONFEDERATE CONGRESS-AN ORDINANCE FOR THE GOVERNMENT OF THE TERRITORY OF THE UNITED STATES NORTHWEST OF TFE RIVER OHIO.

ARticie 5. There shall be formed in the said territory not less than three nor more than five States; and the boundaries of the States, as soon as Virginia shall alter her act of cession and consent to the same, shall become fixed and established as follows, to wit: The western State in said territory shall be bounded by the Mississippi, the Ohio, and the Wabash River, a direct line drawn from the Wabash and Post Vincents due north to the territorial line between the United States and Canada, and by the said territorial line to the Lake of the Woods and Mississippi. The middle State shall be bounded by the said direct line, the Wabash from Post Vincents to the Ohio, by the Ohio, by a direct line drawn due north from the mouth of the Great Miami to the said territorial line, and by the said territorial line. The eastern State shall be bounded by the last-mentioned direct line, the Ohio, Pennsylvania, and the said territorial line: Provided, however, And it is further understood and declared, that the boundaries of these three States shall be subject so far to be altered, that, if Congress shall hereafter find it expedient, they shall.have authority to form one or two States in that part of the said territory which lies north of an east and west line drawn through the southerly bend or extreme of Lake Michigan.

Passed July 13, 1787.

The provisions of this bill seem, however, never to have been carried out. A provisional government was instituted in 1788. By act of May 7, 1800, Congress divided this territory into two Territorial governments, the divisional line being a meridian passing through the mouth of the Kentucky River and extending thence northward to the Canada border. The eastern portion became the "Territory Northwest of the River Ohio," and the western portion, Indiana Territory.

On November 29,1802 , the State of Ohio, comprising most of the former, was formed and admitted into the Union, while the remnant of it was added to Indiana Territory.

In 1805 all that portion of Indiana Territory lying north of a parallel 
through the most southerly bend of Lake Michigan and east of a meridiandrawn through the same point became the Territory of Michigan. The boundary between these Territories was subsequently very much changed, as will appear in the sequel.

By act of February 3, 1809, Indiana Territory was again divided, and the Territory of Illinois was created from the part lying west of the Wabash River and a meridian running through the city of Vincennes, extending thence to the Canada line.

In 1816 Indiana, and in 1818 Illinois, were admitted to the Union as States, each with its boundaries as constituted at present. By the same act the Mississippi River was made the western boundary of the Territory of Michigan, thus making it include all the balance of the original Northwest Territory after the formation of the three States of Ohio, Indiana, and Illinois.

The act of 1834 added to Michigan Territory the land between the Missouri and White Earth rivers on the west and the Mississippi River on the east.

Wisconsin Territory was formed in 1836 from the portion of Michigan Territory west of the present State of Michigan. On January 26, 1837, Michigan was admitted into the Union, with its present boundaries. In 1838 all that portion of Wisconsin Territory lying west of the Mississippi River and a line drawn due north from its source to the international boundary (that is, all that part which was originally comprised in the Louisiana purchase) was made the Territory of Iowa, and in 1848 Wisconsin was admitted as a State, with its boundaries as at present constituted.

This appears to leave the area which is now the northeastern part of Minnesota, lying east of the Mississippi River and a line drawn due north from its source, without any government until the formation of Minnesota Territory, in 1849.

\section{TERRITORY SOUTH OF THE RIVER OHO.}

The "Territory South of the River Ohio" was bounded on the north by the present northern boundary of Tennessee, on the south by the thirty-first parallel of latitude, on the east by the States of Virginia, North Carolina, South Carolina, and Georgia, and on the west by Mississippi River. The different cessions from the States which made up this region are as follows:

1. The area ceded by North Carolina, which extended from $36^{\circ} 30^{\prime}$ north latitude southward to $35^{\circ}$, and from the western boundary line of the present State to the Mississippi River. This is now the State of Tennessee.

2. The area ceded by South Carolina, which formed a narrow belt 12 or 14 miles in width lying south of the thirty-fifth parallel and extending from her western boundary to the Mississippi River. It is 
doubtful whether under the terms of the original charters South Carolina possessed this strip, or whether it was not included in the possessions of Georgia.

3. The area ceded by Georgia, which comprised most of the region of the present States of Alabama and Mississippi north of the thirtyfirst parallel.

Tennessee was admitted as a State in 1796. In 1798 Congress organized the Territory of Mississippi, which was originally a small, rectangular area, bounded on the west by the Mississippi River, on the north by a parallel through the mouth of the Yazoo River; the boundary on the east was the river Chattahoochee, and on the south the thirty-first parallel of north latitude. This area was subsequently enlarged so as to include the whole of what is now Mississippi and Alabama, with the exception of a strip along the Gulf coast, which was at that time claimed by Spain. In 1817 the Territory was divided, and the eastern portion was made into Alabama Territory. Subsequently the two Territories were admitted as States.

\section{LOUISIANA AND THE TERRITORY ACQUIRED FROM MEXICO.}

The Louisiana purchase was effected in 1803 . In 1804 it was divided into two parts, that portion which now comprises the State of Louisiana being organized as Orleans Territory, while the balance remained as the Louisiana Territory. The State of Louisiana, comprising most of the Territory of Orleans, was admitted to the Union in 1812, and in the same year it was enlarged by the addition of the portion lying between the Mississippi and Pearl rivers, in the southeastern part. In the same year the name of Louisiana Territory was changed to Missouri Territory. In 1819 Arkansaw Territory was created, and in 1836 it was admitted as a State.

In 1820 the State of Missouri was formed from another portion of Missouri Territory, and in 1836 the boundaries of this State were enlarged to their present limits. In 1834, as was stated above, that portion of this Territory lying north of the State of Missouri and east of the Missouri and White Earth rivers was attached to the Territory of Michigan. In 1836 this portion was transferred from the Territory of Michigan to the Territory of Wisconsin. In 1838 it was transferred to the Territory of Iowa. In 1845 the State of Iowa was created, and in 1846 its boundaries were enlarged. In 1849 the remainder of the Territory was transferred to Minnesota Territory. Minnesota was admitted as a State on May 11, 1858, with its present boundaries.

Meantime Texas had been admitted to the Union, and by the treaty of Guadalupe Hidalgo and the Gadsden purchase we' had acquired from Mexico all the area west of the northern part of Texas and south 
of the forty-second parallel. . Furthermore, our northern boundary had been established on the forty-ninth parallel to the Pacific Ocean.

Out of this great western region were carved the following Territories:

- Oregon Territory, which was formed in 1848, and which extended from the parallel of $49^{\circ}$ north latitude southward to latitude $42^{\circ}$, and from the Pacific Ocean east to the summit of the Rocky Mountains.

California, which was admitted as a State in 1849 , with the same limits which it possesses at present.

Utah Territory, which was formed in 1850 , and which extended from the forty-second parallel southward to the thirty-seventh, and from the California boundary line eastward to the Rocky Mountains.

New Mexico, which comprised all the country lying south of Utah to the boundary line of Texas and Mexico, and from the California boundary eastward to the boundary of Texas.

Nebraska Territory, which was formed from Missouri Territory in 1854. It comprised the country from the forty-ninth parallel down to the fortieth, and from the Missouri and White Earth rivers west to the summit of the Rocky Mountains.

Kansas Territory, formed by the same act as the last, comprised the country lying west of Missouri to the boundary of New Mexico and Utah, and from the south boundary of Nebraska to the thirty-seventh parallel.

Indian Territory then had its present limits.

Washington Territory was formed in 1853 from a part of Oregon, its southern boundary being Columbia River and the parallel of $46^{\circ}$ north latitude, and its east line being the summit of the Rocky Mountains.

Oregon was admitted as a State in 1857 , with its boundaries as at present established. The portion cut off from Oregon Territory was placed under the Territorial government of Washington.

Dakota Territory was formed in 1861. As originally formed, it comprised all that region between its present eastern and southern boundaries, while its western boundary was the summit of the Rocky Mountains.

The Territory of Nevada was organized from the western portion of the Territory of Utah in 1861. As originally constituted, its eastern line was the meridian of $39^{\circ}$ of longitude west from Washington, and its southern boundary was the parallel of $37^{\circ}$ of latitude. It was admitted as a State in 1864, its eastern boundary being made the thirty-eighth degree of longitude (approximately the one hundred and fifteenth degree west from Greenwich), while its southern boundary remained the same. In 1866, by act of Congress, the eastern boundary was moved one degree farther to the eastward, placing it upon the 
thirty-seventh degree of longitude west. from Washington, and the triangular portion contained between the former southern boundary, the boundary of California, the Colorado River, and the meridian of $37^{\circ}$ of longitude was added, thus giving the State its present area and limits.

Colorado Territory was formed in 1861, with the limits of the present State. It was admitted as a State in 1876.

The Territory of Arizona was formed from New Mexico in 1863, being that portion of New Mexico lying west of the thirty-second meridian west of Washington.

In the same year Idaho was formed from parts of Dakota and Washington Territories. As originally constituted it included all the territory lying east of the present eastern limits of Oregon and Washington Territory to the twenty-seventh degree of longitude west of Washington, the latter meridian being its eastern boundary. Its southern boundary was the northern boundary of Colorado and Utah-that is, the forty-first and forty-second parallels of latitude.

From this Territory was detached, in 1864, the Territory of Montana with its present limits, and in 1868 the Territory of Wyoming, these several changes reducing Idaho to its present dimensions. 


\section{H A P T E R III.}

\section{THE BOUNDARY LINES OF THE STATES AND TERRI- TORIES.}

\section{MAINE.}

The first charter having any relation to the territory comprising the present State of Maine is that granted by Henry IV of France to Pierre du Gast, Sieur de Monts, in 1603, known as the charter of Acadia, which embraced the whole of North America between the fortieth and forty-sixth degree of north latitude. Under this, several expeditions were made, and in 1606 it was decided to make a permanent settlement at Port Royal, now Annapolis, Nova Scotia, and no further attempts were made under this charter to plant colonies within the limits of the present State of Maine. (Vide Charters and Constitutions, p. 771.)

By the first charter of Virginia (vide Virginia, p. 95), granted by James I, in 1606, the lands along the coast of North America between the thirty-fourth and forty-fifth degrees of north latitude were given to two companies, to one of which, the Plymouth Company, was assigned that part of North America including the coast of New England. The first colony in Maine was planted on the Peninsula of Sabine, at the mouth of Kennebec River, now Hunnewell Point, on August 19, 1607, O. S., by George Popham.

James $I$ in 1620 granted a charter to the Plymouth Company, in which may be found the following, viz:

Wee, therefore * * * do grant ordain and establish that all that Circuit, Continent, Precincts and Limitts in America lying and being in Breadth from Fourty Degrees of Northerly Latitude from the Equinoctial Line to Fourty eight Degrees of the said Northerly Latitude and in length by all the Breadth aforesaid throughout the Maine Land from Sea to Sea-with all the Seas, Rivers, Islands, Creekes, Inletts, Ports and Havens within the Degrees, Precincts and Limitts of the said Latitude and Longitude shall be the Limitts, and Bounds, and Precincts of the second collony-and to the end that the said Territoryes may hereatei be more particularly and certainly known and distinguished, our Will and Pleasure is, that the same shall from henceforth be nominated, termed and called by the name of New England in America.

Under this grant, given in 1621, the Earl of Stirling claimed that he was entitled to land on the coast of Maine which was afterwards 
granted to the Plymouth Company, and by direction of James I that company issued a patent to William Alexander, Earl of Stirling,

For a tract of the main land of New England, beginning at Saint Croix and from thence extending along the sea-coast to Pemquid and the river Kennebeck. (Vide Charters and Constitutions, p. 774.)

The heirs of the Earl of Stirling sold this tract to the Duke of York in 1663. (Vide Zell's Encyclopædia.)

In 1622 Capt. John Mason and Sir Ferdinando Gorges obtained from the council of Plymouth a grant of the lands lying between the Merrimac and Kennebec Rivers, and extending back to the river and lakes of Canada. This tract was called Laconia, and it included New Hampshire and all the western part of Maine. (Vide Whiton's New Hampshire.)

Mason and Gorges, in 1629, by mutual consent divided their territory into two by the river Piscataqua. That part on the east of this river was relinquished to Gorges, who called it Maine. (Vide Whiton's New Hampshire.)

The charter of the Plymouth, Company was surrendered to the King in the year 1635. (Vide Plymouth Colony Laws, p. 333 et supra.)

King Charles I, in the year 1639, granted a charter to Sir Ferdinando Gorges, which virtually confirmed the patent given to him by the Plymouth Company in 1622.

The following extract from that charter defines the boundaries:

All that Parte Purparte and Porcon of the Mayne Lande of New England aforesaid beginning att the entrance of Piscataway Harbor and soe to passe upp the same into the River of Newichewanocke and through the same unto the furthest heade thereof and from thence Northwestwards till one hundred and twenty miles bee finished and from Piscataway Harbor mouth aforesaid Northeastwards along the Sea Coasts to Sagadahocke and up the River thereof to Kynybequy River and through the same into the beade thereof and into the Lande Northwestwards untill one hundred and twenty myles bee ended being accompted from the mouth of Sagadahocke and from the period of one hundred and twenty myles aforesaid to crosse over Lande to the one hundred and twenty myles end formerly reckoned upp into the Lande from Piscataway Harbor through Newichewanocke River and also the Northe halfe of the Isles of Shoales togeather with the Isles of Capawock and Nawtican neere Cape Cod as alsoe all the Islands and Iletts lyeinge within five leagues of the Mayne all alonge the aforesaide coasts betweene the aforesaid River of Pascataway and Sagadahocke with all the Creeks Havens and Harbors thereunto belonginge and the Revercon and Revercons Remaynder and Remaynders of all and singular the said Landes Rivers and Premisses. All which said Part Purpart or Porcon of the Mayne Lande and all and every the Premisses hereinbefore named Wee Doe for us our heires and successors create and incorporate into One Province or Countie, and Wee Doe name ordeyne and appoynt that the porcon of the Mayne Lande and Premises aforesaid shall forever hereafter bee called and named The Province or Countie of Mayne.

In 1664 Charles II granted to the Duke of York, who, the year before, had purchased the territory, which had been awarded to the Earl of Stirling in the division of the country to his heirs, a portion of the present State of Maine, and also certain islands on the coast, 
and a large territory west of the Connecticut River. (For the boundaries, vide New York, p. 77 et seq.)

In 1674 Charles II made a new grant to the Duke of York, in substantially the same terms as that of 1664 , including, as before, a portion of Maine. (Vide New York, p. 78.)

In the year 1677, Ferdinando Gorges, a grandson of Sir Ferdinando Gorges sold and gave a deed of the province of Maine to John Ushur, a merchant, of Boston, for $£ 1,250$. In the same year, Ushur gave a deed of the same territory to the governor and company of Massachusetts Bay, who had received a grant from the council of Plymouth in 1628, confirmed by the King in 1629. (Tide C. \& C., p. 774.)

In 1686 Pemaquid and its dependencies, forming Cornwall County, under the jurisdiction of New York, were annexed to the New England government by a royal order, dated September 19, 1686. (Vide Maine Historical Society Collection, vol. 5.)

The charter of Massachusetts Bay of 1629 having been canceled in 1684, in 1691 William and Mary granted a new one, incorporating the provinces of Maine and Acadia, or Nova Scotia, with the colonies of Massachusetts Bay and of Plymouth, into one royal province by the name of the Royal Province of Massachusetts Bay. (Vide Mass., p. 54.)

The right of government thus acquired over the district of Maine was exercised by Massachusetts until 1819, when measures were taken to admit Maine as an independent State.

By the treaty of Paris in 1763, the King of France relinquished all claim to that portion of North America which includes the present State of Maine.

The northern and eastern boundaries were settled by the United States and Great Britain. (See p. 12 et seq.)

The western boundary was for a long time a source of contention between Maine and New Hampshire.

New Hampshire having been máde a province in 1679 , controversies arose concerning the divisional line.

In 1731 commissioners from New Hampshire and from Massachusetts, having been appointed, met, but were unable to agree. New Hampshire appealed to the King, and the King ordered that a settlement should be made by commissioners from the neighboring provinces. The board met at Hampton in 1737. The commissioners fixed on-substantiallythe present boundary, wording their report as follows:

Beginning at the entrance of Pascataqua Harbor, and so to pass up the same to the River Newhichawack, and thro' the same into the furthest head thereof, and thence run north 2 degrees west till 120 miles were finished, from the mouth of Pascataqua Harbor, or until it meets with His Majesty's other governments. (See N. H. Historical Coll., Vol. II.)

This was confirmed by the King, August 5, 1740.

In 1820 Maine was admitted, as an independent State. 
Difficulties having risen about the boundary between Maine and New Hampshire, commissioners were appointed in 1827 from each State to determine the same.

In 1829 the commissioners' report was adopted by each State, and the line then settled upon is as follows, using the language of the commissioners' report, viz:

The report of the commissioners appointed by His Majesty's order in council of February 22nd, 1735, and confirmed by his order of the 5th of August, 1740, having established-

"That the dividing line shall pass up through the mouth of Piscataqua Harbor, and up the middle of the river of Newichwannock, part of which is now called the Salmons Falls, and through the middle of the same to the farthest head thereof, \&c.," and "that the dividing line shall part the Isle of Sholes, and run through the middle of the harbor, between the islands, to the sea on the southerly side, \&c." We have not deemed it necessary to commence our survey until we arrived north, at the head of Salmon Falls River, which was determined by Bryant, at his survey in 1740, to be at the outlet of East Pond, between the towns of Wakefield and Shapleigh. From that point we have surveyed and marked the line as follows, viz:

We commenced at the Bryant Rock, known as such by tradition, which is a rock in the middle of Salmon Falls River, at the ontlet of East Pond, about six feet in length, three feet in breadth, three feet in depth, and two feet under the surface of the water, as the dam was at the time of the survey, to wit, October 1, 1827; said stone bears south seventy-one degrees west, three rods and eight links from a large rock on the eastern bank, marked " 1827;" and bears also from a rock near the milldam (marked "H") north nineteen degrees and thirty minutes west, and distant twelve rods and twenty-one links. At this point the variation of the needle was ascertained to be nine degrees west.

From the above stone the line is north seven degrees and forty-one minutes east, one hundred and seventy-eight rods to East Pond, and crossing the pond three hundred and eleven rods in width to a stone monument which we erected up on the bank, about three and an half feet high above the surface of the ground, marked $\mathrm{N}$ on the west side and $\mathrm{M}$ on the east side, which description applies to all the stone monuments hereinafter mentioned unless they are otherwise particularly described; thence the same course, two hundred and twenty-five rods, to Fox Ridge, and to a stone monument which is placed upon the north side of the road that leads from Wakefield to Shapleigh; thence two hundred rods to Balch's Pond; across the pond, one hundred and three and half rods; across a peninsula, thirty-six rods; across a cove, fifty-one rods and seventeen links; across a second peninsula, forty-eight rods; across a second cove, twenty-seven rods ten links.

Thence three hundred and seventy rods to the road leading from Newfield to Wakefield and a stone monument, erected on the north side of the same, near Campernell's house; thence north six degrees and ten minutes east, five hundred and ninety rods, to the line of Parsonfield, to a stone monument with additional mark "1828."

At this point the variation of the needle was found to be nine degrees fifteen minutes west. Thence same course five hundred and eleven rods, crossing the end of Province Pond to a stone monument on the Parsonfield road, near the house of James Andrews, also with additional mark "1828;" thence north eight degrees and thirtyeight minutes east, two hundred and eight rods, to the old corner-stone of Eftingham, about two feet above the ground, and not marked; thence north eight degrees fiftyfive minutes east, two hundred and seventy-seven rods, to a large round stone about three feet diameter and two feet high, marked $\mathrm{N}$ and $\mathrm{M}$, by the road upon Towles hill; thence north seven degrees fifty-five minutes east, six hundred and thirty-one 
rods to a stone monument, on the road leading from Parsonfield to Effingham. At this point the variation of the needle was found to be 9 degrees thirty minutes west. Thence north five degrees two minutes east, seven hundred thirty-four to a pine stump, upon a small island in Ossipee River at the foot of the falls; thence north ten degrees east, thirty rods, to a stone monument, on the north side of the new road from Yorter to Effingham; thence the same course, five hundred fifty-eight rods, to the top of Bald Mountain; thence same course, three hundred sixteen rods, to the top of Bickford Mountain; thence same course one"hundred and ninety-three rods, to a stone monument, on the north side of the road, leading from Porter to Eaton.

At this point the variation of the needle was found to be nine degrees forty-five minutes west; thence north eight degrees five minutes east, seven hundred and fortyfour rods, to Cragged Mountain; thence same course, sixty-seven rods, to the corner of Eaton; thence same course, seven hundred eighty-seven and an half rods, to the corner of Conway; thence same course, six hundred ten and an half rods, to a stone monument, on the south side of the road, leading from Brownfield to Conway Center; thence north eight degrees east, eight hundred seventy-one rods, to a stone monument on the south side of the road leading from Fryeburg Village to Conway. At this point the variation of the needle was found to be ten degrees west; thence same course, four rods, to a stone monument on the north side of the same road; thence north eight degrees fifteen minutes east, one hundred two rods, to Saco River; thence same course, eighteen rods, across said river; thence same course, six hundred fortyfour rods, to a stone monument on the road leading to Fryeburg Village, on the north side of the river.

This monument is marked as before described, and is about. eight feet high above the ground; thence same course one hundred forty-two rods to Ballard's mill pond; thence same course sixty-one rods six links across said pond; thence same course three hundred forty-four rods to a stone monument on the east side of Chatham road; thence same course six hundred ninety rods to Kimball's pond; thence same course one hundred sixty-six rods across said pond; thence same course sixty rods to a stone monument on the meadow; $a$ thence same course nine bundred and forty rods to the corner of Bradley and Eastman's grant; thence same course six hundred and ninety rods to a stone monument on the east side of the Cold River road. This stone is marked as before described, but is not more than two feet above.the ground. Thence same course one thousand five hundred forty rods to the cormer of Warner and Gilman's location, a pile of stones. At this point the variation of the needle was found to be ten degrees twenty-three minutes west; thence same course four hundred and fifty rods to top of Mount Royce; thence same course eight hundred ninety-eight rods to Wild River; thence same course eight rods across said river; thence same course seven hundred sixty-five rods to a stone monument on the north side of the road leading from Lancaster to Bethel; thence same course one hundred rods to Androscoggin River; thence same course eighteen rods across said river; thence north eight degrees ten minutes east, four thousand one hundred sixtytwo rods, across ten streams; to Chickwalnepg River; thence same course two thousand five hundred rods to a stone monument on the north side of the road leading from Errol to Andover: This stone is marked "N. H." and "M." 'Thence same course two hundred ten rods to Cambridge River; thence same course eight rods across said river; thence same course five hundred sixty-seven rods to Umbagog Lake; thence same course thirty-four rods across a cove of the same; thence same course ten rods across a peninsula of the same; thence same course two hundred twenty-five rods across a bay of said lake; thence same course two hundred six rods across a peninsula of the same; thence same course one thousand one hundred sixty-five rods, across the north bay of said lake, to a cedar post marked "N." "M.;" 
thence north eight degrees east seven hundred fourteen rods to Pond Brook; thence same course two hundred twenty-five rods to a stone monument on the south side of the Margallaway River; thence same course ten rods across said river; thence same course one hundred sixty-two rods to a spruce, comer of the college grant; thence same course two hundred sixty-four rods to Margallaway River a second time. At this point the variation of the needle was found to be eleven degrees forty-five minutes west. Thence same course ten rods across said river; thence same course two hundred and ninety rods to same river a third time; thence same course ten rods across said river to a monument made with three stones on the north side of said river, about two feet high and not marked; thence same course four hundred fortyfour rods to corner of township number five, in second range, in Maine; thence same course one thousand eight hundred six rods to the north corner of the same township; thence same course four hundred and sixty rods to a branch of Little Diamond River; thence same course three hundred fifty rods to another branch of the same; thence same course two thousand one hundred twenty rods to a branch of the Margallaway River; thence same course three hundred thirty-two rods to another branch of the same; thence same course four hundred rods to a steep mountain called Prospect Hill; thence same course nine hundred and twenty rods to Mount Carmel, sometimes called Sunday Mountain; thence same course four hundred rods to a perpendicular precipice; thence same course five hundred and forty rods to a branch of Margallaway River; thence same course two hundred and sixty rods to a branch of the same; thence same course three hundred forty-six rods to a second steep precipice; thence same course one hundred eighty-six rods to a branch of Margallaway River; thence same course, two hundred forty-two rods to another branch of same river; thence same course seventy-eight rods to a beaver pond; thence same course one hundred twenty-six rods to a yellow birch tree on the highlands which divide the waters that run south from those that run into the St. Lawrence, being the northern extremity of the line, and one hundred and twelve miles two hundred and thirty-three rods from the head of Salmon Falls River.

Found said tree marked on the east side "M. E. 1789,". and on the west "N. H. N. E.;" also "M. 54." To these marks we added "N. H.," "N. E," and "M. E.," "1828," "E. H.," "A. M. M.," "1828," and stones were piled round the same and marked.

The whole course of the line from the Androscoggin River was re-marked by spotting the old-marked trees and crossing the spots and marking others in the course. And the line as above surveyed and described we agree to be the true boundary line of said States. And the above-described marks and monuments we establish to designate the same, and that the said line hereafter remain the boundary line between the States, unless the legislature of either State shall, at the first session after the execution of this agreement, disapprove of the same.

$$
\begin{aligned}
& \text { WILLIAM KING, } \\
& \text { RUFUS MCINTIRE, } \\
& \text { Commissioners of Mainc. } \\
& \text { ICHABOD BARTLETT, } \\
& \text { JOHN W. WEEKS, } \\
& \text { Commissioners of New Hampshire. }
\end{aligned}
$$

Novemiber 13, 1828.

The legislature of Maine approved of the commissioners' report February 28, 1829, and requested the governor to issue his proclamation accordingly.

The same action was taken by the legislature of New Hampshire, July 1, 1829. 
(For Report of Commissioners, see Laws of Maine, 1828-9, under head of Resolves of the Ninth Legislature of the State of Maine, pages 39-43.)

Between 1828 and 1858 considerable portions of the almost unbroken forests through which the line of 1827-28 was marked were cleared. Extensive forest fires often swept large tracts of this territory, and, as a consequence, the marks of the 1827-28 survey for a distance of nearly eighty miles-which by that survey was mainly fixed by blazed trees-only seven stone posts having been set in this distance-were obliterated, so that there remained scarcely a vestige of the original line. The lands having become valuable, and litigation in many cuses being imminent, the legislatures of the two States in 1858 provided by enactment for another survey from Fryeburg to the Canada linewhich was made the same year. The line as then surveyed is as follows, viz:

Commencing at an iron post $a$ situated on the line run in accordance with the "Treaty of Washington, of August 9, 1842," as the boundary between the United States and the province of Canada, at the corners of the States of Maine and New Hampshire. On the south face of said post are the words "Albert Smith, U. S. Comssr." ; on the north face, "Lt. Col. I. B. B. Eastcourt, H. B. M. Comssr." ; on the west face, "Boundary. Aug. 9, 1842"; on the east face, "Treaty of Washington." To the marks are added on the southern half of the west face, "H. O. Kent." A large flat stone was placed on the southern face of the monument and marked "1858-N. H., Me.," on either side of a line cut in said stone bearing the direction of the State's line, viz, south, 8 degrees west.

From this point the line is south 8 degrees west, 17 rods 7 links to a large yellow birch stub, the northern terminus of the former survey; thence 126 rods to a beaver pond; thence 78 rods to the northwesterly branch of the Margallaway, known as Kent River; thence 242 rods to another branch of the Margallaway; thence 186 rods to a certain steep precipice perpendicular on its southern face; thence 346 rods to a branch of the Margallaway River; thence 260 rods to another branch of the same; thence 540 rods to a precipice, the southern side of Mount Abbott; thence 400 rods to the summit of Mount Carmel; thence 920 rods, and across four streams, to the summit of Prospect Hill.

On this distance we marked a yellow-birch tree "H. O. Kent, September 20,1858," and the names of the remainder of the party; thence 400 rods to another branch of the Margallaway; thence 332 rods to the Little Margallaway River; thence 2,120 rods across Bosebuck Mountain to a'branch of said river. On this distance at the northwest corner of township No. 5 , range 3 , in Maine, we marked a white-birch tree, "N. H. M.," and on its north and south sides "IV, III." Thirty rods trom the summit of Bosebuck Mountain, and on its northern slope, we erected a stone monument marked "N. M."; thence 350 rods to the Little Diamond River or Abbott Brook; thence 460 rods to the north west corner of township No. 5, range 2, in Maine. On this distance we found an ancient yellow-birch tree marked "1789-35, M." To these marks we added " 1858 "; thence 1,806 rods to the south west corner of the same township. On this distance, at the northeast corner of Dartmouth College, second grant in N. H., we marked a large yellow-birch tree "Me., J. M. W., 1858; N. H., H. O. K."; thence, and across an open bog, 444 rods to the north bank of the Margallaway River, to a

a The position of this post is given in Hitchcock's Geological Survey of New Hampshire as follows, viz: Latitude, $45^{\circ} 18^{\prime} 23^{\prime \prime} .33$; longitude, $71^{\circ} 5^{\prime} 40^{\prime \prime} .5$. 
white-maple tree marked "N. H. M."; thence 10 rods across said river to a large pine tree marked "M." "N. H."; thence and across a second open bog 290 rods to the same river and to a large elm stub; thence 10 rods across said river; thence 264 rods to a spruce post marked "M." "N. H.", "W. L.", "D. C.", being the southeast corner of Dartmouth College, second grant; thence 162 rods to the Margallaway River; thence 10 rods across said river to a stone monument on its southerlý side, standing about 3 feet above the ground and marked "M." "N H."; thence to the original line tree nearest to the clearing of the home farm of Z. F. Durkee, esq. The course of the line the entire distance from the iron post at the national boundary to this point bears south eight degrees west; thence across said clearing, the old line marks being gone, south 11. degrees and 30 minutes west, 168 rods, to the old crossed trees in the woods south of Pond Brook; thence from Pond Brook south eight degrees west, 714 rods to the north bog of Umbagog Lake and to a cedar tree marked "M." "N." To this we added "1858."

On this distance near the corner of Errol and Wentworth's location, which is a cedar post in a pile of stones, we marked a maple tree "M. 1858," "N. H. 1858"; thence south ten degrees and thirty minutes west 1,165 rods, across the north bay of said lake to the old marked trees on the southern shore; thence south eight degrees west 206 rods across the peninsula to a cedar tree marked "M." "N. H." A large stone, also, on the lake shore was marked "M." "N. H."; thence same course 225 rods, across a bay of said lake; thence same course 10 rods, across a peninsula; thence same course 34 rods, across a cove; thence same course 567 rods, to Cambridge River; thence same course 8 rods, across said river to a white-maple stub; thence same course 210 rods, to a stone monument on the north side of the road leading from Andover, Me., to Colebrook, N. H.; thence same course to the north edge of the burnt land in Grafton and Success; thence south 11 degrees west across ten streams and the Chickwalmpy River, or Silver Stream, to the old line trees bearing the crosses, easterly of the south end of Success Pond; thence on the same course south 10 degrees west, following the old mark to an ash tree bearing the original cross, standing a few rods north of the house of the late Daniel Ingalls, in Shelburne; thence south 11 degrees west to a stone monument, by the road on the north side of the Androscoggin River, and to the north bank of said river, the whole distance from the stone monument near Umbagog Lake to the north bank of the Androscoggin River, being 6,662 rods; thence south 11 degrees west 18 rods across said river; thence same course 100 rods, crossing the track of the Grand Trunk Railway to a stone monument on the north side of the road leading from Lancaster, N. H., to Bethel, Me.; thence same course 765 rods, to a hemlock tree on the south bank of Wild River; thence south 66 degrees 30 minutes west 34 rods, on an offset of the old survey along said south bank to the old line trees; thence following the old line trees south 11 degrees west, passing the southeast corner of Shelburne, 898 rods to the top of Mount Royce, the whole distance being 1,881 rods. One mile north of the summit of Mount Royce we marked a beech tree "N. H." "M." 1858; thence to a large stone marked "N. H." "Me."; thence south 10 degrees 15 minutes west to a stone monument on the east side of the Cold River road. On this distance at the foot of the first precipice on the northern face of Mount Royce a white-birch tree was marked "1858." Further on and east of a bare ledge a white-birch tree was marked "1858," and near it, on the line, a pile of stones was erected. At the first clearing, near the north end of a stone fence, a large stone was marked "M." "N. H."; thence along a stone fence and across a road through a piece of new growth and again crossing the road; then following another stone fence on the east side of the road, passing through a field and by the end of another stone fence; then crossing a road near the west end of a bridge over Cold River; then following the valley of that stream and crossing it six times; then crossing another road, where we placed a stone monument; then through a field, striking an old stump and pile of stones, shown as the old line and passing between 
a house and barn, and through the western edge of a grove of trees to the stone monument near the house of Mr. Eastman, the whole distance being 1,190 rods; thence 1,630 rods to a stone monument standing in the meadow 60 rods north of the north. shore of Kimball's Pond, in Fryeburg.

But as the towns of Fryeburg and Stowe have erected no durable monument on the State's line at their respective corners, we deemed it advisable, under our instructions, to proceed so far south as at least to pass the said corner and to complete the work at some well-defined monument of the old survey.

This course bore from the monument to and across an open bay south 12 degrees west; thence on the old trees south 9 degrees west 100 rods; thence on the old line south 10 degrees 30 minutes west to a stone monument erected by us near the house of Jonnet Clay, in Chatham, and on the north side of the road leading from Stowe to Chatham Corners; said monument is marked "M." "N. H." 1858; thence on the old line south 11 degrees west to the road leading from North Fryeburg to. Chatham, at which point we placed a stone monument; thence south 11 degrees west to the northwest corner of Fryeburg, being a stake in a pile of stones in a piece of low ground, southerly of the house of Captain Bryant, and to the old monument, 60 rods north of Kimball's Pond. On the bank north of said corner, on the south side of the road, and near Captain Bryant's house, we placed a stone monument marked "M." "N. H. 1858."

The different courses laid down in the foregoing report are the bearings of the compass in 1858 when placed on the line established in 1828. (See Legislative Journal of New Hampshire, 1859, pages 764-767.)

In 1874 the line between Maine and New Hampshire was resurveyed and marked. (Vide Hitchcock's Geology of New Hampshire, Vol. I, p. 173.)

\section{NEW HAMPSHIRE.}

The first charter of Virginia, granted in 1606, included the territory of the present State of New Hampshire (vide p. 39), as did the charter of New England, granted in 1620 (vide p. 39), and the grant to Capt. John Mason and Sir Ferdinando Gorges of 1622 (vide p. 40).

The president and council of New England made a grant to Capt. John Mason in 1629 as follows, viz:

All that part of the main land in New England lying upon the sea coast, beginning from the middle part of Merrimack River, and from thence to proceed northwards along the sea-coast to Piscataqua River, and so forwards up within the said river and to the furthest head thereof, and from thence north westwards until three scoremiles be finished from the first entrance of Piscataqua River and also from Merrimack through the said river and to the furthest head thereof, and so forward up into the lands westward until three score miles be finished, and from thence to cross overland to the three score miles, and accompted to Piscataqua River, together with all islands and islets within 5 leagues distance of the premises and abutting upon the same, or any part or parcel thereof, \&c., * * * which said portions of lands $* * *$ the said Capt. John Mason, with the consent of the president and council, intends to name New Hampshire. * * *

In 1635 the grant of 1629 was confirmed by a supplementary grant, of which the following is an extract, viz:

All that part of the Mayn Land of New England aforesaid, beginning from the middle part of Naumkeck River, and from thence to proceed eastwards along the Sea 
Coast to Cape Anne, and round about the same to Pischataway Harbour, and soe forwards up within the river Newgewanacke, and to the furthest head of the said River and from thence northwestwards till sixty miles bee finished, from the first entrance of Pischataway Harbor, and alsoe from Naumkecke through the River thereof up into the land west sixty miles, from which period to cross over land to the sixty miles end, accompted from Pischataway, through Newgewanacke River to the land northwest aforesaid; and alsoe all that the South Halfe of the Ysles of Sholes, all which lands, with the Consent of the Counsell, shall from henceforth be called New-hampshyre. And alsoe ten thousand acres more of land on the southeast part of Sagadihoc at the mouth or entrance thereof-from henceforth to bee called by the name of Massonia, \&c.

After the death of Capt. John Mason (in December, 1635), the affairs of the colony coming into bad condition, they sought the protection of Massachusetts in 1641 and enjoyed it till 1675, when Robert Mason, a grandson of John Mason, obtained a royal decree, under which, in 1680, a colonial government was established. But no charter was given to the colony, and its government was only continued during the pleasure of the King. The following is an extract from the commission, or decree, issued by the King in 1680:

Province of New Hampshire, lying and extending from three miles northward of Merrimack River or any part thereof into ye Province of Maine.

In the year 1690 the province of New Hampshire was again taken under the jurisdiction of. Massachusetts Bay, but was again separated in 1692.

[For a history of the boundary between New Hampshire and Maine, vide Maine, p. 41.]

The controversy already referred to, arising between the provinces of New Hampshire and Massachusetts Bay, not only involved- the settlement of the boundary between New Hampshire and Maine, but also that between New Hampshire and Massachusetts, and, as before stated (vide Maine, p. 41), the commissioners appointed by the two provinces having been unable to agree, New Hampshire appealed to the King, who ordered that the boundaries should be settled by a board of commissioners appointed from the neighboring colonies.

The board met at Hampton in 1737, and submitted a conditional decision to the King, who in 1740 declared in council as follows, viz:

That the northern boundary of the province of Massachusetts be a similar curve line pursuing the course of the Merrimac River, at three miles distance, on the north side thereof, beginning at the Atlantic Ocean and ending at a point due north of Pautucket Falls, and a straight line drawn from thence, due west, till it meets with His Majesty's other Governments. (Vide Vermont State Papers, Slade, p. 9.)

New Hampshire claimed her southern boundary to be a line due west from a point on the sea three miles north of the mouth of Merrimac River. Massachusetts claimed all the territory three miles north of any part of Merrimac River. The King's decision gave to New Hampshire a strip of territory more than fifty miles in length, 
and of varying width, in excess of that which she claimed. This decree of the King was forwarded to Mr. Belcher, then governor of both the provinces of New Hampshire and Massachusetts Bay, with instructions to apply to the respective assemblies to unite in making the necessary provisions for running and marking the line conformable to the said decree, and if either assembly refused, the other was to proceed ex parte. Massachusetts Bay declined complying with this requisition. New Hampshire, therefore, proceeded alone to run and mark the line.

George Mitchel and Richard Hazen were appointed by Belcher to survey and mark the line. Pursuant to this authority, in the month of February, 1741, Mitchel ran and marked the line from the seacoast about three miles north of the mouth of the Merrimac River to a point about three miles north of Pawtucket Falls, and Hazen, in the month of March following, ran and marked a line from the point, three miles north of Pawtucket Falls, across the Connecticut River, to the supposed boundary line of New York, on what he then supposed to be a due west course from the place of beginning. He was instructed by Governor Belcher to allow for a westerly variation of the needle of ten degrees. ( Vide New Hampshire Journal H. R., 1826.)

The report of the surveyors has not been preserved, but the journal of Hazen has been found, and is published in the New England Historical and Genealogical Register, July, 1879.

Subsequent investigation has proved that this line was not run on a due west course, the allowance for the westerly variation of the needle being quite too large, throwing the line north of west.

This mistake seems to have been known previous to the Revolution. In 1774 calculations were made by George Sproule, founded upon actual surveys and accurate astronomical observations, from which he determined that Hazen's line was so far north of west as to lose to the State of New Hampshire quite a large tract of land. (Vide New Hampshire Journal H. R., 1826.)

In 1825 commissioners were appointed by the States of New Hampshire and Massachusetts to ascertain, run, and mark the line between the two States, under the proceedings of which New Hampshire asserted her claim to a due west line, conformable to the decree of 1740 , it being apparent by a survey made by the commissioners that the original line was north of west. This the Massachusetts commissioners refused to do, alleging that they were only empowered to ascertain and mark the original line.

On March 10, 1827, the legislature passed a resolution providing for the erection of durable monuments to preserve the boundary line between the States of Massachusetts and New Hampshire, as the same had been run and ascertained by the commissioners, and monuments wère erected accordingly. (Vide Resolves of Massachusetts, 1827.) 
In 1885 the joint commission appointed by the States of New Hampshire and Massachusetts reran and marked the curved portion of the boundary, following the course of Merrimac River, changing it only to a trifling extent. This commission was, however, unable to agree upon the boundary west of Pawtucket Falls. This matter dragged along until finally in 1894 this commission, together with a commission representing Vermont, agreed to maintain the Hazen line, and this line was retraced and re-marked from Pawtucket Falls to the northwest corner of Massachusetts.

Under the decree of the King of 1740 the province of New Hampshire claimed jurisdiction as far west as the territory of Massachusetts and Connecticut extended, thus including the present State of Vermont. New York claimed all the country west of the Connecticut, under the charters of 1664 and 1674 to the Duke of York. A bitter controversy ensued. The following papers serve to throw some light on the matter:

Letter f.om the Governor of New Hampshire to the Governor of New York.

Pontsmouth, November 17,1749 .

* * * I think it my duty * * * to transmit to your excellency the description of New Hampshire as the King has determined it in the words of my commission.

* * * In consequence of His Majesty's determination of the boundaries between New Hampshire and Massachusetts, a surveyor and proper chainmen were appointed to run the western line from 3 miles north of Pautucket Falls, and the surveyor upon oath has declared that it strikes Hudson's River about 80 poles north of where Mohawk's River comes into Hudson's River.

(See State Papers of Vermont, Slade, 1, page 10.)

B. WENTWORTH.

The following is a description of the bounds of New Hampshire given to Governor Benning Wentworth, of province of New Hampshire, by George II, July 3, 1741:

George the Second, by the Grace of God, of Great Britain, France, and Ireland King, Defender of the Faith, \&c.

To our trusty and well-beloved Benning Wentworth, esqr., greeting:

Know you that we, reposing especial trust and confidence in the prudence, courage, and loyalty of you, the said Benning Wentworth, out of our especial grace, certain knowledge, and mere motion, have thought fit to constitute and appoint, and by these presents do constitute and appoint you, the said Benning Wentworth, to be our governor and commander in chief of our province of New Hampshire, within our dominions of New England in America, bounded on the south side by a similar curve line pursuing the course of Merrimac River at three miles distance, on the north side thereof, beginning at the $A$ tlantick Ocean and ending at a point due north of a place called Pautucket Falls, and by a straight line drawn from thence due west cross the said river 'till it meets with our other Governments.

Given at Whitehall July the $3 \mathrm{rd}$, in the 15 th year of His Majesty's reign.

(See Documentary History of N. York, vol. 4, page 331.) 
The question of the right of territory was submitted to the King, who in 1764 made the following decree:

ORDER IN COUNCIL FIXING THE BOUNDARY JETWEEN NEW YORK AND NEW HAMPSHIRE.

[L. s.]

At 'Tre Cour't a't ST. James, The 2oth day of July, $1^{\prime} 764$.

Present: The King's Most Excellent Majesty; Lord Steward, Earl of Sandwich, Earl of Halifax, Earl of Powis, Earl of Hilsborough, Mr. Vice-Chamberlain Gilbert Eliot, esqr., James Oswald, esqr., Earl of Harcourt.

Whereas there was this day read at the Board a report made by the right honorable the lords of the committee of council for plantation affairs, dated the 17th of this instant, upon considering a representation from the lords commissioners for trade and plantations, relative to the disputes that have some years subsisted between the provinces of New Hampshire and New York, concerning the boundary line between those provinces, His Majesty, taking the same into consideration, was pleased with the advice of his Privy Council to approve of what is therein proposed, and doth accordingly hereby order and declare the western banks of the river Connecticut, from where it enters the province of the Massachusetts Bay, as far north as the forty-fifth degree of northern latitude, to be the boundary line between the said two provinces of New Hampshire and New York. Whereof the respective governors and commanders in chief of His Majesty's said provinces of New Hampshire and New York for the time being, and all others whom it may concern, are to take notice of His Majesty's pleasure hereby signified and govern themselves accordingly.

WM. BLAIR.

(Vide Documentary History of New York, vol. 4, p. 355.)

Notwithstanding this decree of the King, controversy, attended with violence, was kept up for many year's; but the line was finally accepted and now forms the boundary line between the States of New Hampshire and Vermont.

The northern boundary of New Hampsbire was settled by the United States and Great Britain. (Vide p. 17 et seq.)

It is as follows, viz:

Commencing at the "Crown Monument," so called, at the intersection of the State of New Hampshire, Maine, and the Province of Quebec, in latitude $45^{\circ} 18^{\prime} 23^{\prime \prime} .33$, longitude $71^{\circ} 5^{\prime} 40^{\prime \prime} .5$, thence in an irregular line to Hall's Stream, thence down the same to the northeastern corner of Vermont, in latitude $45^{\circ} 0^{\prime} 17^{\prime \prime} .58$, longitude $71^{\circ} 30^{\prime}$ $34^{\prime \prime} .5$. (Vide Hitch. Geology of New Hampshire.)

\section{VERMONT.}

The grants from King Henry, of France, of 1603, and King James, of England, of 1606, both included that territory which forms the present State of Vermont. It was also included in the charter of New England of 1620 .

In the grants to the Duke of York, in 1664 and 1674, all the territory between the Connecticut and Delaware rivers was included. New. York, therefore, claimed jurisdiction of the territory now known as Vermont. Massachusetts, however, at an early period, having made 
claim to the tract west of the Connecticut River, now a portion of that State, by the interpretation of her charter, claimed the greater part of the same territory. By the terms of the charter of Massachusetts Bay, of 1629 , that colony was granted all the lands-

Which lye and be within the space of Three English myles to the northward of the saide River called Monomack alias Merrymack, or to the norward of any and every Parte thereof.

Under this clause Massachusetts Bay claimed that her jurisdiction extended 3 miles north of the farthest part of the Merrimac River, which would embrace a large portion of New Hampshire and Vermont. New Hampshire contested this claim, and after several years' controversy was more than sustained by a decision of the King in 1740 . New Hampshire in her turn claimed the territory of Vermont, on the ground that Massachusetts and Connecticut, having been allowed to extend their boundaries to within 20 miles of the Hudson River, her western boundary should go equally as far, and contended that the King's decree of 1740 left that fairly to be inferred; also, that the old charters of 1664 and 1674 were obsolete.

By a decree of the King, however, the territory west of the Connecticut River, from the 45th parallel of north latitude to the Massachusetts line, was declared to belong to the province of New York. (Vide New Hampshire, p. 51.)

As most of the settlers of Vermont were from New Hampshire, this decision of the King caused great dissatisfaction, and the Revolution found Vermont the scene of conflicting claims, and the theater of violent acts, culminating, in some instances, in actual bloodshed.

On January 15, 1777, Vermont declared herself independent and laid claim to the territory west as far as Hudson River, and from its source north to the international boundary, including a tract along the west shore of Lake Champlain. A part of New Hampshire, also, at one time sought a union with Vermont.

In 1781 Massachusetts assented to her independence. She adjusted her differences with New Hampshire in 1782, but eight years more passed before New York consented to her admission into the Union.

In 1791 Vermont was admitted as an independert State, but was required to restrict her boundaries to their present extent.

The act of New York, of March 6, 1790, giving her consent to the admission of Vermont, defines her boundaries. (Vide Slade's Vermont, p. 507.)

The northern boundary was settled by the United States and Great Britain by the treaty of Washington, in 1842. (Vide p. 17.)

The eastern boundary is low-water mark on the west bank of the Connecticut River. (Vide New Hampshire, p. 51.)

The southern boundary was settled by the decree of 1740. (Vide New Hampshire, p. 48.) 


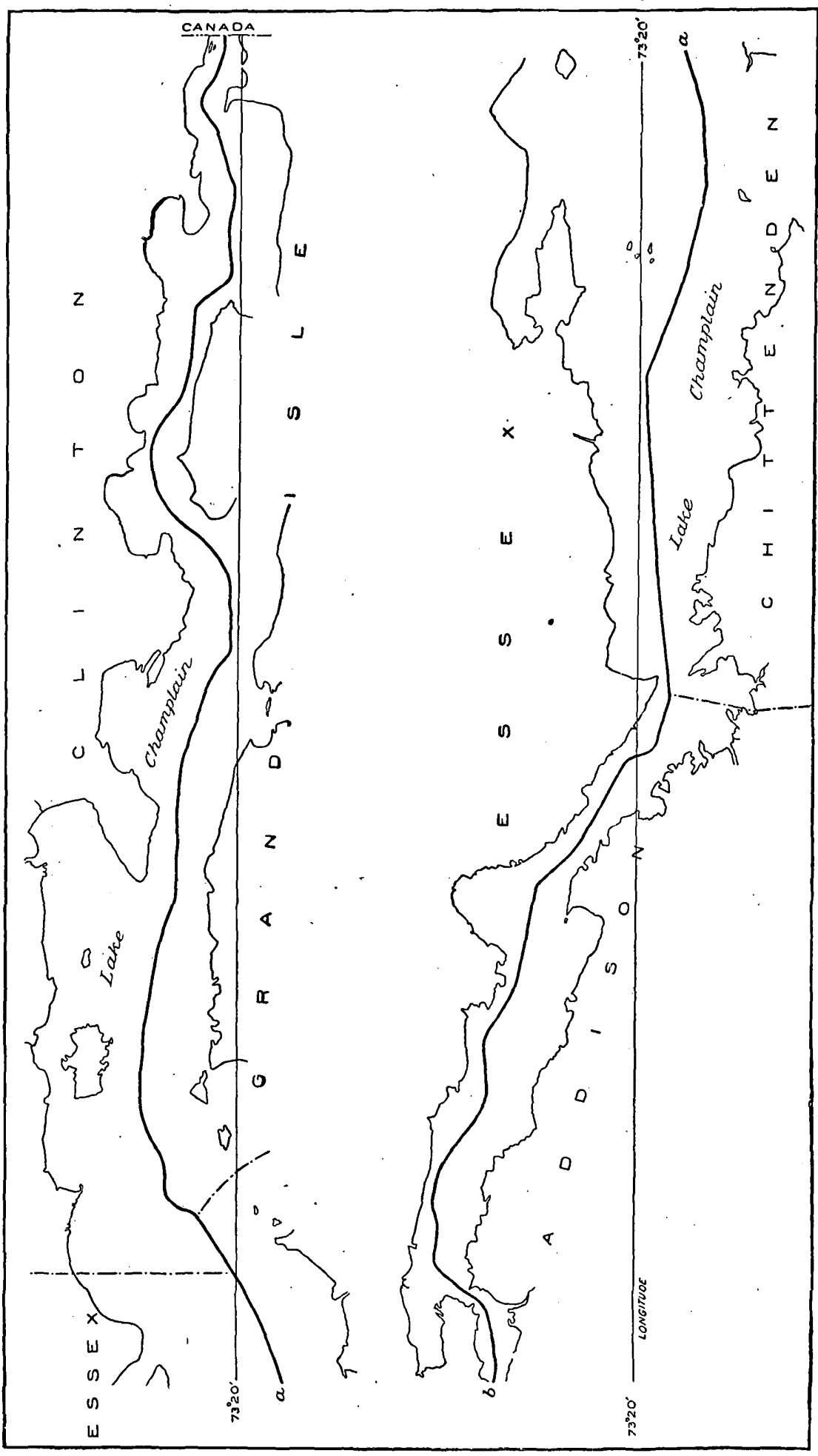




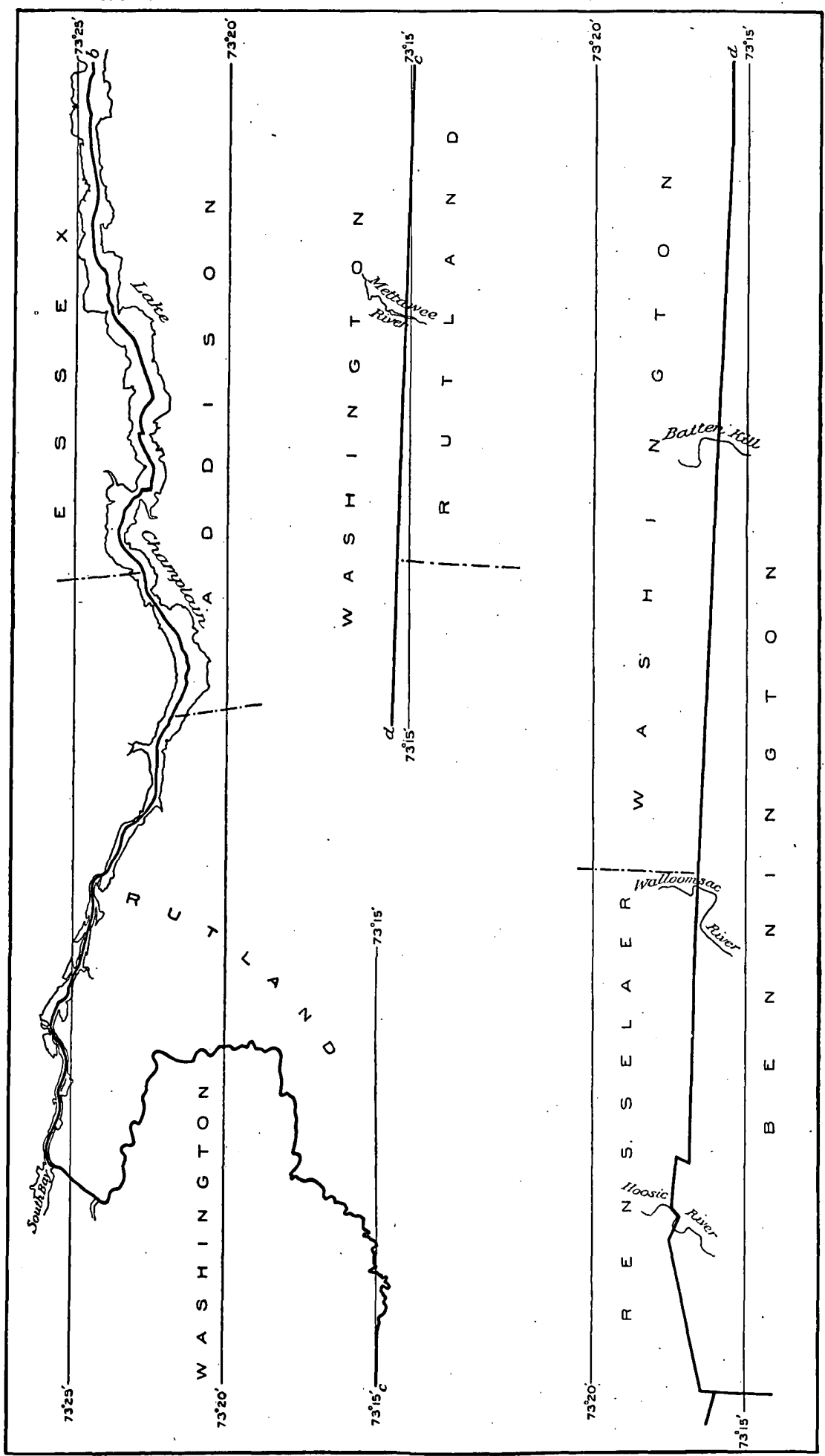

BOUNDARY BETWEEN VERMONT AND NEW YORK,

Bull. $226-04-6$ 
The line between Vermont and New York waș surveyed and marked by commissioners from the two States in 1814, and is as follows, viz:

Beginning at a red or black oak tree, the northwest corner of Massachusetts, and running north $82^{\circ} 20^{\prime}$ west as the magnetic needle pointed in 1814, 50 chains, to a monument erected for the southwest corner of the State of Vermont, by Smith Thompson, Simon De Witt, and George Tibbitts, commissioners on the part of New York, and Joseph Beeman, jr., Henry Olin, and Joel Pratt, second, commissioners on the part of the State of Vermont, which monument stands on the brow of a high hill, descending to the west, then northerly in a straight line to a point which is distant 10 chains, on a course south 35 degrees west, from the most westerly corner of a lot of land distinguished in the records of the town of Pownal, in the State of Vermont, as the fifth division of the right of Gamaliel Wallace, and which, in the year 1814, was owned and occupied by Abraham Vosburgh; then north 35 degrees east, to said corner and along the westerly bounds of said lot, 30 chains, to a place on the westerly bank of Hasick River where a hemlock tree heretofore stood, noticed in said records as the most northerly corner of said lot; then north 1 degree and 20 minutes west, 6 chains to a monument erected by the said commissioners, standing on the westerly side of Hasick River, on the north side of the high way leading out of Hasick into Pownal, and near the north westerly corner of the bridge crossing said river; then north 27 degrees and 20 minutes east; 30 chains, through the bed of the said river, to a large roundish rock on the northeasterly bank thereof; then north 25 degrees west, 16 chains and 70 links; then north 9 degrees west, 18 chains and 60 links, to a white oak tree, at the southwest corner of the land occupied in 1814 by Thomas Wilsey; then north 11 degrees east, 77 chains, to the north side of a highway, where it is met by a fence dividing the possession of said Thomas Wilsey, jr., and Emery Hunt; then north 46 degrees east, 6 chains; then south 66 degrees east, 26 chains and 25 links; then north 9 degrees east, 27 chains and 50 links, to a blue-slate stone, anciently set up for the southwest corner of Bennington; then north 7 degrees and 30 minutes east, 46 miles 43 chains and 50 links, to a bunch of hornbeam saplings on the south bank of Poultney River, the northernmost of which was marked by said lastmentioned commissioners, and from which a large butternut tree bears north 70 degrees west, 30 links, a large hard maple tree, south 2 chains and 86 links, and a white ash tree on the north side of said river, north 77 degrees east.

Which said several lines from the monument erected for the southwest corner of the State of Vermont were established by said last-mentioned commissioners, and were run by them, as the magnetic needle pointed, in the year 1814, then down the said Poultney River, through the deepest channel thereof, to East Bay; then through the middle of the deepest channel of East Bay and the waters thereof to where the same communicate with Lake Champlain; then through the deepest channel of Lake Champlain to the eastward of the islands called the Four Brothers, and the westward of the islands called the Grand Isle and Long Isle, or the Two Heroes, and to the westward of the Isle La Motte to the line in the 45th degree of north latitude, established by treaty for the boundary line between the United States and the British Dominions. (See Revised Statutes of New York, Banks \& Brothers, sixth edition, Vol. I, pp. 122-123.)

This line was changed in 1876 by a cession of a small territory from Vermont to New York, described as follows, viz:

All that portion of the town of Fairhaven, in the county of Rutland, and State of Vermont, lying westerly from the middle of the deepest channel of Poultney River, as it now runs, and between the middle of the deepest channel of said river and the west line of the State of Vermont as at present established." (Ratified by Congress April 7, 1880.) 


\section{MASSACHUSETTS.}

The territory of Massachusetts was included in the first charter of Virginia, granted in 1606 (Vide Virginia, p. 95), and in the charter of New England, granted in 1620 (Vide Maine, p. 39).

In 1628 the council of Plymouth made a grant to the governor and company of Massachusetts Bay in New England, which was confirmed by the King, and a charter was granted in 1629, of which the following are extracts:

* * * Nowe Knowe Yee, that Wee * * * have given and granted * * * all that Parte of Newe England in Amirica which lyes and extends betweene a great River there commonlie called Monomack River, alias Merrimack River, and a certen other River there, called Charles River, being in the Bottome of a certen Bay there, comonlie called Massachusetts alias Mattachusetts, alias Massatusetts Bay, and also all and singuler those Landes and Hereditament whatsoever, lying within the Space of Three Englishe Myles on the South Parte of the said River called Charles River, or of any or every Parte thereof. And also all and singuler the Landes and Hereditaments whatsoever, lying and being with the space of Three Englishe Miles to the south ward of the southermost Parte of the said Baye, called Massachusetts, alias Mattachusetts, alias Massatusetts Bay-and also all those Lands and Hereditaments whatsoever, which lye and be within the space of Three English Myles to the Northward of the saide River, called Monomack, alias Merrymack, or to the Norward of any and every Parte thereof and all Landes and Hereditaments whatsoever, lyeing within the Lymitts aforesaide, North and South, in Latitude and Bredth, and in Length and Longitude, of and within all the Bredth aforesaide, throughout the Mayne Landes there from the Atlantick and Westerne Sea and Ocean on the East Parte, to the South Sea on the West Parte.

* * * Provided alwayes, That yf the said Landes * * * were at the tyme of the graunting of the saide former Letters patents, dated the Third Day of November, in the Eighteenth yeare of our said deare Fathers Raigne aforesaide, actuallie possessed or inhabited by any other Christian Prince of State, or were within the Boundes Lymitts or Territories of that Southern Colony, then before graunted by our saide late Father * * * That then this present Graunt shall not extend to any such partes or párcells thereof *** but as to those partes or parcells $* * *$ shal be vtterlie voyd, theis presents or any Thinge therein conteyned to the contrarie notwistanding ***

The charter of New England was surrendered to the King in 1635. ( Vide Plymouth Colony Laws, p. 333.)

The charter of 1629 was canceled by a judgment of the high court of chancery of England, June 18, 1684. (Vide C. \& C., p. 942.)

In the year 1686 Pemaquid and its dependencies were annexed to the New England government. (Vide Maine, p. 41.)

In 1691 a new charter was granted to Massachusetts Bay, which included Plymouth Colony and the Provinces of Maine and Nova Scotia. The following are extracts from this charter:

* * Wee *** do will and ordeyne that the Territories and Collonyes Commonly called or Known by the names of the Collony of the Massachusetts Bay and Collony of New Plymouth the Province of Main the Territorie called Accadia or Nova Scotia and all that tract of Land lying betweene the said Territories of Nova Scotia and the said Province of Main be erected Vnited and Incorporated * * * 


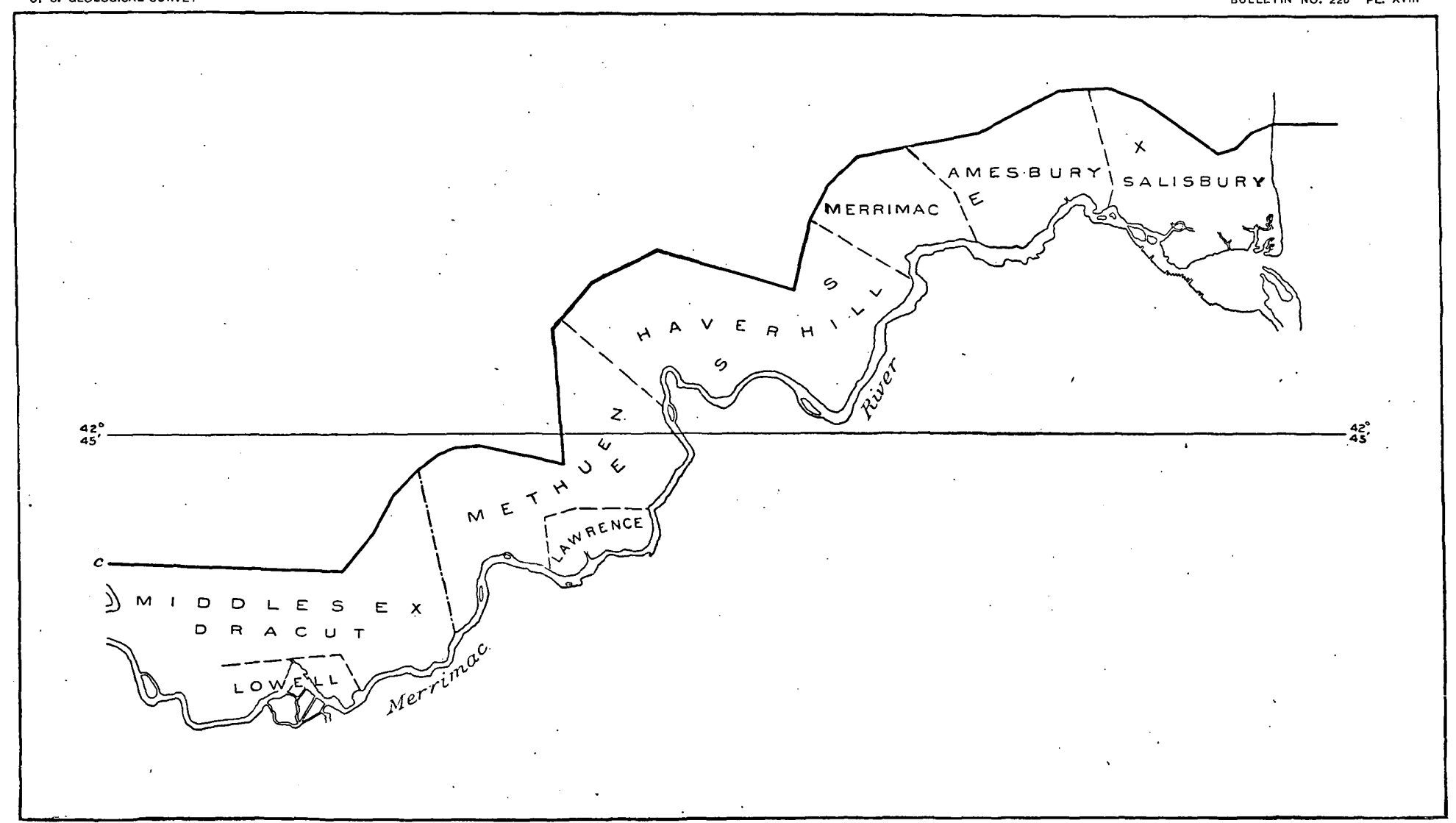



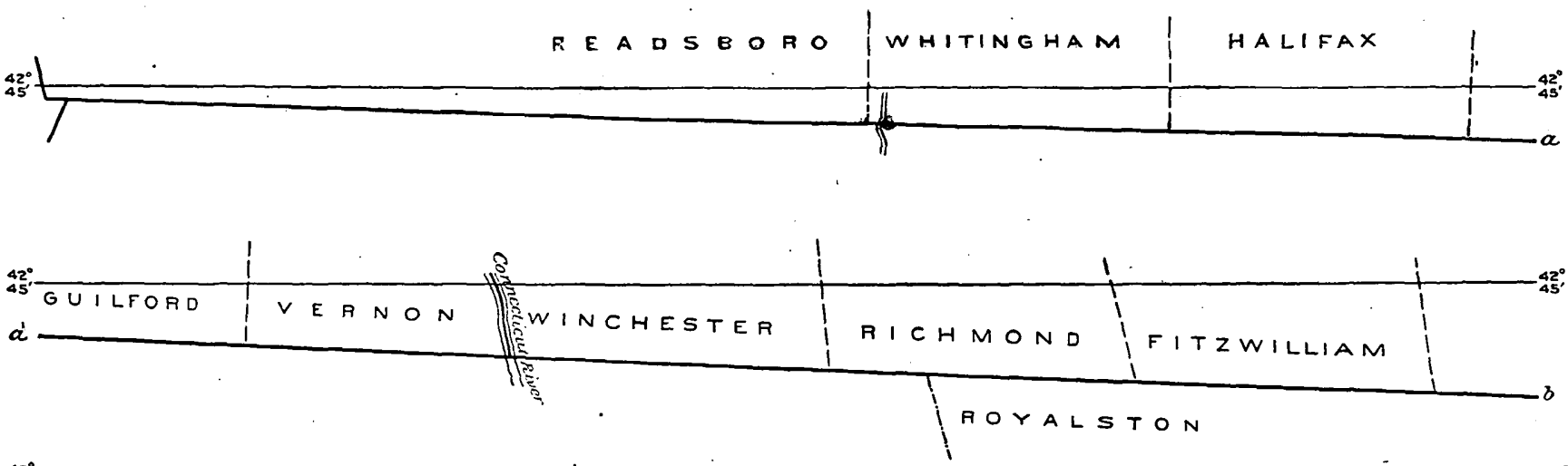

$42^{\circ}$ 
into one reall Province by the Name of Our Province of the Massachusetts Bay in New England. * * *

All that parte of New England in America lying and extending from the greate River co monly called Monomack als Merrimack on the Northpart and from three Miles Northward of the said River to the Atlantick or Western. Sea or Ocean on the South part And all the Lands and Hereditaments whatsoever lying within the limitts aforesaid and extending as farr as the Outermost Points or Promontories of Land called Cape Cod and Cape Mallabar North and South and in Latitude Breadth and in Length and Longitude of and within all the Breadth and Compass aforesaid throughout the Main Land, there from the said Atlantick or Western Sea and Ocean on the East parte towards the South Sea or Westward as far as Our Collonyes of Rhode Island Connecticutt and the Narragansett Countrey all alsoe all that part or porc̃on of Main Land beginning at the Entrance of Pescataway Harbour and soe to pass vpp the same into the River Newickewannock and through the same into the furthest head thereof and from thence Northwestward till One Hundred and Twenty miles be furnished and from Piscataway Harbour mouth aforesid North-Eastward along the Sea Coast to Sagadehock and from the Period of One Hundred and Twenty Miles aforesaid to crosse over Land to the One Fundred and Twenty Miles before reckoned up into the Land from Piscataway Harbour through Newickawannock River and alsoe the North halfe of the Isles and Shoales togather with the Isles of Cappawock and Nantukett near Cape Cod aforesaid and alsoe [all] Lands and Hereditaments lying and being in the Countrey and Territory coñonly called Accadia or Nova Scotia And all those Lands and Hereditaments lying and extending betweene the said Countrey or Territory of Nova Scotia and the said River of Sagadahock or any part thereof And all Lands Grounds Places Soiles Woods and Wood grounds Havens Ports Rivers Waters and other Hereditaments and premisses whatsoever, lying within the said bounds and limitts aforesaid and every part and parcell thereof and alsoe all Islands and Isletts lying within tenn Leagues directly opposite to the Main Land within the said bounds.

(For an account of the settlement of the boundary between the District of Maine, formerly a part of Massachusetts, see Maine, p. 41.)

The present northern boundary of Massachusetts was settled in 1741. (For history, see New Hampshire, p. 49.)

The boundary line between Massachusetts and Rhode Island was for more than two hundred years a question of dispute, and was, in some respects, the most remarkable boundary case with which this country has had to do. Twice the case went to the Supreme Court of the United States, and in one of these suits Daniel Webster and Rufus Choate were employed as counsel for Massachusetts.

As early as 1642 the line between the two colonies was marked in part by Nathaniel Woodward and Solomon Saffrey, who set up on the plain of $\mathrm{W}$ rentham a stake as the commencement of the line between Massachusetts Bay and Rhode Island. This stake was by them supposed to mark a point 3 miles south of the Charles River.

The report of these commissioners has not been found, but frequent reference is made to their survey in the record of the subsequent controversies and litigations.

In 1710-11 commissioners appointed from Massachusetts and Rhode Island agreed upon the north line of Rhode Island. The action of the commissioners was approved by the legislatures of both colonies. 
The agreement was as follows, viz:

That the stake set up by Nathaniel Woodward and Solomon Saffrey, skillful, approved artists, in the year of our Lord 1642, and since that often renewed in the latitude of $41^{\circ} 55^{\prime}$, being 3 English miles distant south ward from the southernmost part of the river called Charles River, agreeable to the letters patent for the Massachusetts Province, be accounted and allowed on both sides the commencement of the line between the Massachusetts and the colony of Rhode Island, from which said stake the dividing line shall run, so as it may (at Connecticut River) be $2 \frac{1}{2}$ miles to the southward of a due west line, allowing the variation of the compass to be $9^{\circ}$; which said line shall forever, \&c. (Vide Howard's Reports, S. C., Vol. 4, p. 631, et seq.)

In 1719 this line was run by commissioners appointed for the purpose. Subsequent investigation has shown that this line was lun in a very irregular manner. (Vide R. I. Acts, May, 1867, page 6, et seq.)

The line between Massachusetts and the eastern part of Rhode Island was fixed by commissioners in 1741, from the decision of whom the colony of Rhode Island appealed to the King, who, in the year 1746 , affirmed their decision by a róyal decree.

The following is a record of the proceedings in council, together with the royal decree:

[Council office. Coincil Register: Geo. II, No. 8, p. 204.]

\section{At the Court at Kensington, the 29th day of July, 1742 .}

Present: The Kings Most Excellent Majesty, Archbp. of Canturbury, Earl of Pembroke, Lord President Earl of Winchelsea, Lord Privy Seal Earl of Grantham, Duke of Bolton, Earl of Cholmondelly, Duke of Rutland, Earl of Wilmington, Marq ${ }^{\mathrm{s}}$ of Tweedale, Earl of Bath, Visco ${ }^{t}$ Lonsdale, Mr. Chancellor of the Excher ${ }^{\text {cr }}$, Lord Delaware, Sr. Charles Wager, Lord Bathurst, Sr. William Younge, Lord Monsore, Sr. John Norris, Mr. Speaker Thomas Winnington, esq., Mr. Vice Chamberlin, George Wade, esq.

Upon reading this day at the board the humble Petetion and appeale of the Governor and company of the English of Rhode Island and Providence Plantations in New England in America from several particular parts of the determination of the commissioners appointed by his Majesty to settle the Boundary's of the said colony Eastwards with the Province of Massachusetts Bay, and humbly praying that a day may be appointed for hearing said appeal, and that the particular parts of the said commissioners' determination appealed from may be reversed, and such other determination made instead thereof as shall be agreeable to the true construction of the Boundarys contained in the Royal Charter under which the Petioners claim, it is ordered by his Majesty in Council that the said Petition and appeal (a copy whereof is hereunto annexed) be and it is hereby referred to the Right Honorable the Lords of the committee of council for hearing appeals from the Plantations to hear the same, and report their opinion thereupon to his Majesty at the Board.

A true copy.

\section{B. LENNARD.}

Collated with the original entry in the Council Register, 18 Jan'y, 1845. ROBT. LEMON

[Council office. Council Register. Geo. II, No. 8, p. 235.]

At the Court of Kensingtón, the 15th day of Sept., 1742.

Present: The Kings Most Excellent Majesty Archbp of Canturbury, Lord Delinar Lord Chancellor, Mr. Vice Chamberlin, Duke of Richmond, Mr. Chancellor of the 
Exchequer, Duke of 'Newcastle, Harry Pelham esq. Earl of Winchelsea, Thomas Winnington, esq., Earl of Wilmington, George Wade, esq., Lord Cartaret.

Upon reading this day at the Board the humble Petition and appeale of His Majesty's Province of the Massachusetts Bay in New England from the determination of the commissioners appointed by His Majesty to settle the Boundary of the Colony of Rhode Island Eastwards, with the said province of Massachusetts Bay and humbly praying that a day may be appointed for hearing the said appeale, and that the determination of the said commissioners may be reversed, and such other determination made instead thereof as shall be agreeable to the petioners' claim exhibited before the said commissioners-It is ordered by his Majesty in council that the said petition and appeale (a copy whereof is hereunto annexed) be and it is hereby referred to the Right Honorable the Lords of the committee in council for hearing appeals from the Plantations to hear the same and report their opinion thereupon to His Majesty at the Board.

A true copy.

I. B. LENNARD.

Collated with the original entry in the Council Registry, 18 of Jan'y, 1845. ROBT. LEMON.

[Ordered in council, dated 28th May, 1746. Council office. Council Register. Geo. II, No. 10, p. 498.]

At the Court of Kensington, the $28 t h$ day of May, 1746 .

Present the Kings Most Excellent Majesty in Council

Upon reading at the Board a Report from the Right Honourable the Lord of the committee of council for hearing appeals from the Plantations dated the 11th of December, 1744, in the words following vizt.

Your Majesty having been pleased by Your Order in council of the 29th of July, 1742 , to refer unto this committee the humble petition and appeale of the Governor and company of the English Colony of Rhode Island and Providence Plantations in New England in America, from several particular parts of the determination of the commissioners appointed by your Majesty to settle the Boundarys of said colony eastwards with the Province of Massachusetts Bay and humbly praying that the particular parts of the said commissioners' determination appealed from may he reversed, and such other determinations made instead thereof, as shall be agreeable to the true construction of the Boundarys continued in the Royal Charter under which the petitions claim-and your Majesty having been also pleased by another order in council of the 15th of September, 1742, to refer unto this committee the humble Petition and appeal of your Majesty's Province of the Massachusetts Bay in New England parte of the said determination of the said commissioners, and humbly praying that the same may be reversed and set aside and that instead thereof Your Majesty will be graciously pleased to give such judgment and determinations as shall. be agreeable to the petitioners' claim exhibited before the said commissioners. The Lords of the committee in obedience to your Majesty's said orders of Reference, have met several times, and taken both the said Petitions of Appeale into their consideration, and having examined into the Proceedings of the said commissioners, do find that they pronounced their judgements or determination on the 30th of June, 1741, in the words following:

The court took into consideration, the charters, Deeds and other Evidences, Claims Pleas and allegations produced and made by parts refering to the controversy before them and after mature advisement, came to the following Resolutions: That there is not any one Evidence proving that the Water between the Main Land on the East, and Rhode Island on the West, was ever at any time called Naragansett River, that though there be evidence that the place where the Indian called King Philip lived near Bristol, was called Pawconoket, and that another place near Swanzey 
was called Sowams or Sowamsett, yet no evidence has been produced of the extent of the Pawconoket country to Seaconk, or Pawtucket River, as it runs to the line of the late Colony of the Massachusetts Bay, for tho' there be some evidence that the Indians at enmity with King Philip, or with other Indians in enmity with him, lived on the west side of the said River, and that the Indians subject to King Philip, or in amity with him, lived on the East side of the said River there is no Evidence that all the Indians subject to, or in amity with King Philip, lived in the Pawconoket Country. That the Province not having produced the Letters Patent, constituting the council of Plymouth, nor any copy thereof, the Recital of said Letters Patent in the deed from the council of Plymouth, to Bradford and his associates, is not sufficient evidence against the Kings Charter. That the council of Plymouth being a Corporation, could not create another corporation, and that no Jurisdiction within the Kings Dominions in America can be held by Prescription or on the Foot of Prescription. That the determination of the boundarys of the colony's of Rhode Island and New Plymouth by the Kings Commissioners in the year 1664 appear to have been only a temporary order for preserving the Peace on the Borders of both Colonys without determining the Rights and Titles of either. Upon the whole nothing appears whereby the Colony of Rhode Island and Providence plantations can be barred or hindered from extending their Jurisdiction Eastward towards the Province of the Massachusetts Bay according to the true intents and meaning of their charter. But some dispute having arisen between the Partys as to the true construction and meaning thereof, the court is of opinion, That the Narragansett Bay is and extendeth itself from Point Judith in the west to Seaconet Point on the East and including the Islands therein, layeth and extendeth itself unto the mouth of the River which runnith towards the town of Providence and that as it so lies or extends, it has and may be considered as having one Eastern Side as the Eastern coast of the said Bay runs up northerly from Seconets Point,- and one other North Eastern Side from near Mount Hope to Bullocks Neck, as the said Bay runs up North Westerly towards the Town of Providence and that the land adjacent to the said North Eastern and Eastern Coasts and including within the following lines and the said Bay are within the Jurisdiction of the Colony of Rhode Island; Vizt on the North East side of the said Bay-one line running from the south west corner of Bullocks Neck, Northeast three Miles. One other line running from the Northeast extremity of the said line until it be terminated by a line three miles Northeast from the northeasternmost part of the Bay on the west side of Rumstick Neck, and one other line from the termination of the west line to the Bay at or near Towoset Neck, running so that it touch the North East extremity of a line running three miles North East from the North East corner of Bristol Harbour, and on the Eastern side of the said Bay; One line from a certain point on the Eastern side of the said Bay opposite to the southernmost part of the Shawmuts Neck, and four hundred and forty Rods to the Southwards of the Mouth of Fall River running East three miles; One other line running from the Easternmost extremity of the said line till it be terminated by the Easternmost end of a line three miles East from the Easternmost part of a cove in the said Bay which is to the southward of Nawquaket and one other line from the termination of the last line to the sea, running on such course, as to be three miles East from the Easternmost part of the Bay adjoining to Scitchuwest on Rhode Island, and that the said Distances of three miles East and Northeast, are to be measured from high Water Mark, and this court doth hereby settle, adjust and determine, that the Eastern Boundary of the said Colony of Rhode Island and Providence Plantations, towards the Massachusetts Bay, is, shall be and runs from a certain Pointe (where a Meridian line passing through Pawtuckets Falls, cuts the South Boundary of the Colony of Massachusetts Bay), south to Pawtuckets Falls, Then southerly along the eastward side of Seaconk River, and the River which runnith towards the Town of Providence, to the Southwest corner of Bullock's Neck, then Northeast three miles; and then along the aforesaid lines running at three 
miles distance from the Easternmost parts of the said Bay to the sail Bay, at or near Towoset Neck. Then as the said Bay runs to the southernmost point of Shawmuts Neck, and then in a straight line to the aforesaid point opposite to the said Neck. Then East three miles and then along the aforesaid lines, running at three miles distance from the Lasternmost parts of the said Bay, to the sea. All which lines are to be run by making the proper allowance for the variation of the Magnetic. Needle from the Meridian. And for the better understanding of the description of the lines before mentioned; the Court hath caused the Boundary lines of the lands adjacent to the said most eastern and Northeastern points of the Said Bay, to be delineated on the Map or Plan of the said Bay and countries adjacent now in court, and the same are distinguished on the said Map or Plan, by A, B, C, D, E, F, G, H.

- The Lord of the Committee having considered the whole matter and heard all partys concerned therein by their Council learned in the Law, Do agree humbly to report to your Majesty as their opinion, That the said Judgment or determination of the said Commissioners should be affirmed and both the Petitions of Appeal therefrom dismissed.

His Majesty this day took the said Report into consideration and was pleased with the advice of the Privy Council to approve thereof, and to order, that the said Judgment or Determination of the said Commissioners, Be, and it is hereby Affirmed And both the said Petitions of Appeal therefrom dismissed.

Whereof the Governor or the Commander in Chief of His Majesty's Province of the Massachusetts Bay, The Governor and Company of the colony of Rhode Island and Providence Plantations for the time being, and all others whom it may concern, are to take notice and govern themselves accordingly.

A true Copy.

\section{B. LENNARD.}

Collated with the Original entry in the Council Register, 18 January, 1745. ROBT. LEMON.

\section{Under the foregoing decree the line was run by commissioners} appointed for the purpose, whose report was as follows, viz:

We, the subscribers, appointed commissioners by the general assembly of the colony aforesaid, to mark out the bounds of said colony eastward towards the province of Massachusetts Bay, agreeable to His Majesty's royal determunation in council, the 28th day of May, 1746, did in pursuance thereof, on the second day of December last past, meet at Pawtucket Falls, in expectation of meeting with commissioners that might be appointed by the province of the Massachusetts Bay, for the purpose aforesaid; and after having there tarried till the afterpart of said day, and no commissioners in behalf of the said province appearing, we proceeded to run a due north line from Pawtucket Falls to the south boundary of the aforesaid province of the Massachusetts Bay, in manner following, viz: From a certain point on the southern side of Pawtucket Falls, where we erected a monument of stones, with a stake thereon, we run a meridian line which directly passed through said falls, to a walnut tree on the northerly side of said falls; then to a pitch pine tree; then to a small white oak; then to a grey oak; then to a small bush; then to another small bush with stones about it; then to a heap of stones with a stake thereon; then to a black oak tree; then to another black oak; then to a small pitch pine; then to a black oak; then to a large white oak near the river, called Abbot's Run; then to a poplar tree; then to a heap of stones with a stake thereon; then to a large rock with stones thereon; then to a small black oak tree; then to a walnut tree; then to a black oak; then to divers other -marked trees in the said course, to the extremity of said line; and when we came near the termination of the said line made a monument of stones, there being no noted south boundary of the said province near the said line, and therefore, for 
the discovery of the south boundary of the said province, upon the best information we could obtain, proceeded to Wrentham Plain, at or near to a place where was formerly erected a stake, called Woodward's and Saffery's stake, as one remarkable south boundary of the said province, and from thence run a west line, making an allowance of eight degrees and a half as the west variation of the magnetic needle from the true meridian, it being the course of the south line of the said province, according to their charter (as we apprehended), and then we extended the said north line from the aforesaid monument till it intersected the said west line, and upon the point of its intersection erected a monument of stones with a stake thereon, as the northeast boundary of that tract of land commonly called the Gore.

After which we proceeded to Bullock's Neck, and on the southeast corner thereof erected a red cedar post, marked with the letters J. H. C. R., with the figure of an anchor thereon, and from thence running a line northeast, making the same allowance for the variation aforesaid, to a black oak tree marked with the letters G. C. C. R., then to a large white oak marked with the letters G. B. C. R., then to a white oak post, set in the ground with a heap of stones around it, marked with the letters G.W C. R., with the figure of an anchor thereon, being three miles distant from Bullock's Neck aforesaid.

After which we proceeded to the northeasternmost part of the bay on the west side of Rumstick Neck, and from a point where a locust post was erected run a line three miles northeast, with the same allowance for the variation and at the extremity of the said line erected a monument of stones, from which we run a line to the northeast extremity of that line drawn from the southwest corner of Bullock's Neck aforesaid, the course whereof being west thirty-eight degrees north, according the magnetic needle, the distance of nine hundred and fifty-five rods, marking trees and making other boundaries in the course of said line. After which we proceeded to the northeast corner of Bristol Harbour, and from high-water mark, which was some rods distant northeast from the bridge leading to Swanzey Ferry, we ran a line three miles northeast, still making the same allowance for the variation, and at the extremity of which line we erected a monument of stones; then we ran a line from the northeast extremity of the line drawn from Rumstick aforesaid, the course whereof being south twenty-five degrees east, till it met with the termination of the line drawn from Bristol. Harbour aforesaid, the distance whereof being nine hundred and twentyseven rods; and from thence to a straight line to the bay at Towoset Neck, making proper boundaries in the course of said line.

After which we proceeded to the eastern side of the Narragansett Bay, and on the easternmost part of a cove in the said bay, which is southward of Nanequachet, ran a line three miles east (still making the same allowance for variation), at the extremity whereof we marked a grey oak tree with the letters $C . R$., with the figure of an anchor thereon.

After which we proceeded to the mouth of Fall River, and from thence measured four hundred and forty rods southerly on the shore, as the said shore extendeth itself from the mouth of said Fall River, and from the point where the said four hundred and forty rods reached, being east thirty-five degrees south of the southernmost point of Shawomet Neck, we ran a line three miles east, with the same allowance for the variation; in the course whereof we marked divers trees, and came to a large pond, on the west of which was a small oak between two large rocks, and from thence measured over the said pond to a bunch of maples, two whereof we marked with the letters I and F, standing on a place called Ralph's Neck, being the extremity of the said three miles; from thence we ran a line south twenty degrees west, two thousand one hundred and twenty-three rods (making proper boundaries in said line), till we met the termination of the three-mile line, ran from the cove southward of Nanequachet aforesaid.

After which we proceeded to a place called Church's Cõve, in said bay, and ran a 
U. S. GEOLOGICAL SURVEY

BULLETIN NO. $226 \quad$ PL. $X X$

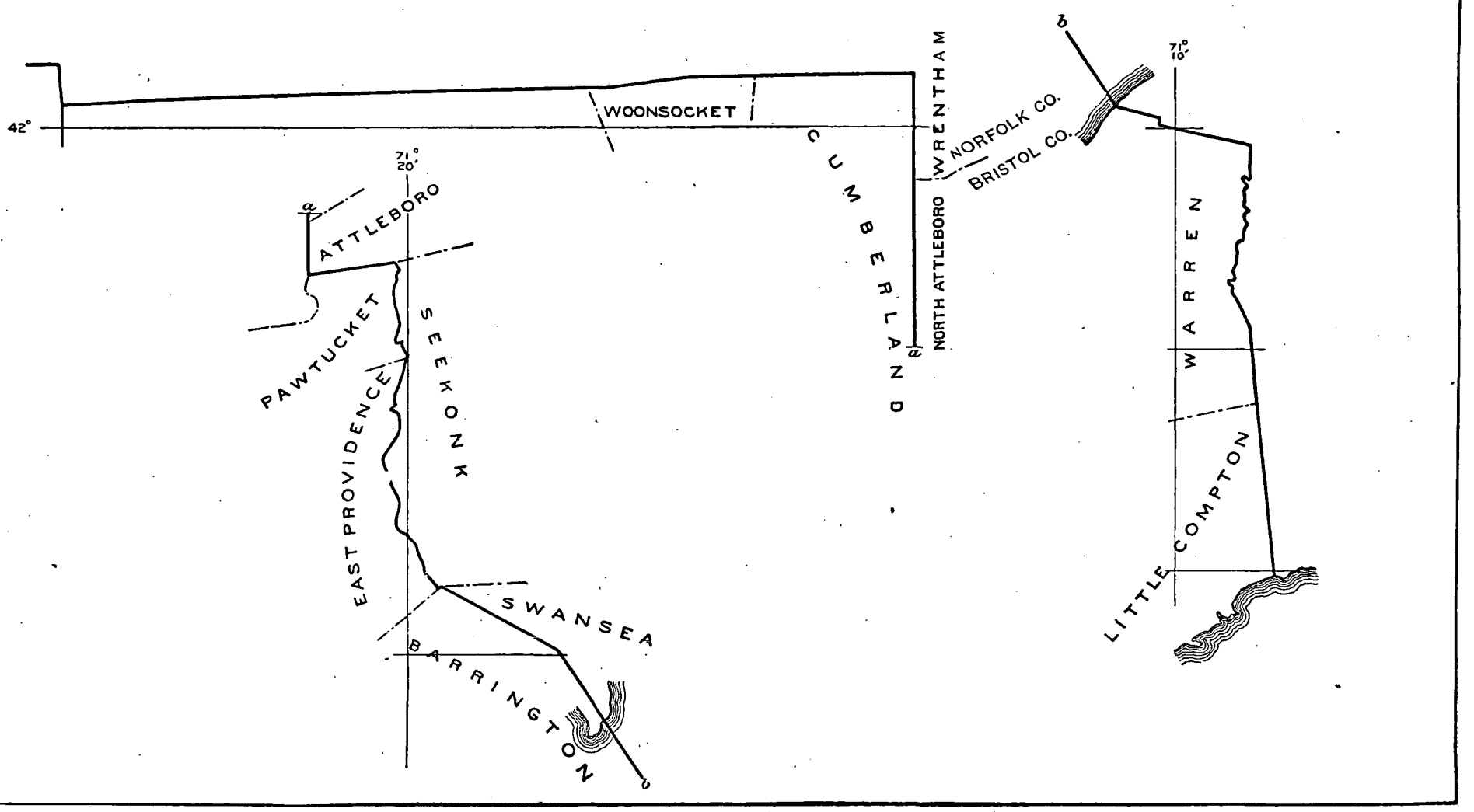

BOUNDARY BETWEEN MASSACHUSETTS AND RHODE ISLAND. 
line three miles east, making the same allowance for the variation aforesaid, and at the extremity whereof, and near the sea; we erected a monument of stones, and from thence ran a line north two degrees and a quarter east, one thousand and nine hundred and forty-one rods, till it also met the termination of the said line, drawn from the first mentioned cove as aforesaid, making proper boundaries in the course of said line.

The aforegoing is a just account of our proceeding.s, and report the same accordingly.

\section{J. HONEYMAN, JR. GEORGE WANTON GIDEON CORNELL. GLORGE BROWN.}

And it is voted and resolved, That the said report be, and it is hereby, accepted by this assembly.

In the year 1748 the legislature of Rhode Island appointed commissioners to continue the line to the Connecticut corner, recognizing the Woodward and Saffrey stake as the place of beginning. Massachusetts failed to appoint commissioners, whereupon the Rhode Island commissioners proceeded to complete the running of the line. In their report they say-

That we not being able to find any stake or other moniment which we could imagine set up by Woodward and Saffrey, but considering that the place thereof was described in the agreement mentioned in our commission, by certain invariable marks, we did proceed as followeth, namely: We found a place where Charles. River formed a large current southerly, which place is known to many by the name of Pappatalish Pond, which we took to be the southernmost part of said river, from the southernmost part of which we measured three English miles south, which three English miles did terminate upon a plain in a township called Wrentham. (See Howard's Reports S. C., vol. 4, page 632).

From this point they ran the line. From this time forward repeated steps were taken by Rhode Island by resolutions, and by appointment of commissioners at different times to ascertain and run the line, in connection with commissioners from Massachusetts; commissioners from both colonies met more than once, but they failed to agree upon a boundary in place of that established under the agreements of 1711-18. Rhode Island alleged a mistake in her commissioners, in the place of beginning (that is, on Wrentham Plain), as the ground of these efforts.

This controversy, however, embraced the entire line from the State of Connecticut to the Atlantic Ocean. Massachusetts asserted that an encroachment had been made on her territory from - Burnt Swamp Corner to the ocean by Rhode Island, who, on her part, claimed that the jurisdictional line of Massachusetts from. said corner to the Connecticut line was, in its whole extent, upon the territory of Rhode Island. The legislatures of the respective States having failed, after repeated effort, to adjust the controversy, Rhode Island in 1832, by a bill in equity, brought the subject of the northern boundary, from Burnt Swamp Corner to the Connecticut line, before the Supreme

Bull. $226-04-7$ 
Court of the United States, which in 1846 decided that the jurisdictional line claimed by. Massachusetts was the legal boundary of the two States between these points.

While this suit was pending an attempt was made to settle the long controversy by an amicable adjustment of the whole line from Connecticut to the ocean. Commissioners were appointed by both States in 1844 to ascertain and mark the true boundary from Pawtucket Falls to Bullock Neck. In 1845 the same commissioners were authorized to ascertain the line from Burnt Swamp Corner to the Atlantic Ocean.

In 1846 , the equity suit having been decided, they were authorized "to erect suitable monuments at the prominent angles of the line, from the Atlantic Ocean to the northwest corner of Rhode Island, and at such other points on the line as may subserve the public convenience." A majority of said commissioners agreed upon a line and erected monuments in 1847 .

The report of the joint commission was dated Boston, January 13, 1848 .

The line so agreed upon as a boundary between Burnt Swamp Corner and the northwest corner of Rhode Island was a straight line, varying a little from the irregular jurisdictional line established by the decision of the Supreme Court, and is described in the joint report of the majority of the commissioners of January, 1848, as follows, viz:

Begin at the north west corner of Rhode Island, on Connecticut line, in latitude $42^{\circ}$ $00^{\prime} 29^{\prime \prime}$ north, and longitude $71^{\circ} 48^{\prime} 18^{\prime \prime}$ west of Green wich, thence easterly in a straight line 21.512 miles to Burnt Swamp Corner, in Wrentham, being in latitude $42^{\circ} 01^{\prime} 08^{\prime \prime}$ and longitude $71^{\circ} 23^{\prime} 13^{\prime \prime}$.

Upon this line were placed twenty-seven monuments, exclusive of that at Burnt Swamp Corner.

The general assembly of Rhode Island, in May, 1847, ratified and established the line from the ocean to the Connecticut line, "to take effect and become binding whenever the said agreement and boundary line should be ratified by the State of Massachusetts." The legislature of Massachusetts did not ratify the said agreement and boundary line, but proposed another joint commission, which was agreed to.

The attempt made by these commissioners to settle the line having failed, Massachusetts commenced a bill in equity before the Supreme Court of the United States for an adjudication of the boundary line from Burnt Swamp Corner to the Atlantic Ocean.

In 1860 both States agreed upon a conventional line, and asked that a decree of the United States Supreme Court should confirm the same, which prayer was granted, and the line was thus finally established by a decree rendered in the December term, 1861, which is as follows, viz:

Beginning at Burnt Swamp Corner (so called), in Wrentham, in latitude $42^{\circ} 01^{\prime} 08^{\prime \prime}$ north, longitude $71^{\circ} 23^{\prime} 13^{\prime \prime}$ west of Greenwich, being the northeasterly corner of Rhode Island. 
Thence in a straight line to the center of a stone monument in the division line, between Attleborough and Pawtucket, on the easterly bank of the Blackstone River, being in latitude $41^{\circ} 53^{\prime} 36^{\prime \prime}$ north, longitude $71^{\circ} 23^{\prime} 14^{\prime \prime}$ west.

Thence easterly, by the northerly line of the town of Pawtucket, to a point where said line intersects the highest water mark on the easterly side of Farmer's or Seven Mile River, which point is shown on accompanying sheet marked "A," and designated as "Bound No. 1," being in latitude $41^{\circ} 53^{\prime} 54^{\prime \prime}$ north, longitude $71^{\circ} 20^{\prime} 40^{\prime \prime}$ west.

From Bound No. 1 the line runs southerly, following the highest water mark on the easterly side of Farmer's or Seven Mile River, as designated in said sheet marked "A," to its junction with the highest water mark on the southerly and easterly side of Ten Mile River, at a point designated as "Bound No. 3."

From Bound No. 3 the line runs southerly; following the highest water mark on the southerly and easterly side of said Ten Mile River, as shown on sheet marked "A," to a point designated as "Bound No. 13," said last point being at the most southerly bend of Ten Mile River in said line of highest water mark.

The line of "highest water mark" as shown on Sheet A is defined by offsets at right angles to straight lines shown on said plan in blue ink, from Bound No. 1, and passing through points designated as bounds numbered 2 to 13 , inclusive.

From Bound No. 13 the line runs southeasterly, being a straight line to the center of a stone pier in the middle of Runnin's River, on the north side of the road leading by Luther's store.

Thence through the center or middle of said Runnin's River as the same is at low water at a point when such line intersects the dividing line between Barrington and Seekonk, being in latitude $41^{\circ} 46^{\prime} 28^{\prime \prime}$, longitude $71^{\circ} 19^{\prime} 23^{\prime \prime}$.

Thence northeasterly, following the dividing line between Barrington and Seekonk, to a point at the northerly extremity of the dividing line between Barrington and Swanzey, in latitude $41^{\circ} 36^{\prime} 34^{\prime \prime}$, longitude $71^{\circ} 19^{\prime} 30^{\prime \prime}$.

Thence in a straight line southeasterly to the center of a copper bolt in King's Rock, so called and well known, near an ancient monument on said King's Rock, being on the west side of the road leading from Warren to Swanzey. This point is in latitude $41^{\circ} 45^{\prime} 22^{\prime \prime} .98$, longitude $71^{\circ} 16^{\prime} 35^{\prime \prime} .75$.

From King's Rock the line follows the dividing line between Warren and Swanzey to Mount Hope Bay, running in a stright line southeasterly to a point on the Birch Swamp Farm, in latitude $41^{\circ} 45^{\prime} 08^{\prime \prime}$, longitude $71^{\circ} 15^{\prime} 58^{\prime \prime} .5$.

Thence in a straight line to Mount Hope Bay, passing through the center of a copper bolt in a bowlder, in line of extreme high water at Toweset, to low-water line of said bay. This bolt is in latitude $41^{\circ} 42^{\prime} 45^{\prime \prime} .27$, longitude $71^{\circ} 13^{\prime} 54^{\prime \prime} .70$.

From Toweset the line runs southeasterly, crossing Mount Hope Bay, to the westerly end of line dividing Fall River and Tiverton, where the same intersects low-water line of said Mount Hope Bay.

Thence easterly, following said dividing line between Fall River and Tiverton, passing through the middle of a town way on the north side of farm belonging to John Chase, and through the southerly end of Cool's Pond, in a line passing through the middle of a highway eight rods wide.

Thence running southerly through the center of said eight-rod highway to a point in line with the stone wall on northerly side of farm of Edmund Estes. This wall is easterly of the Stafford road (so called).

Thence running easterly in line with said wall to a point in line of highest watermark on the westerly shore of South Watuppa Pond, which point is shown on accompanying sheet marked " $\mathrm{B}$," and designated as "Bound A."

From Bound $\mathrm{A}$ the line runs southerly, following the highest watermark on westerly side of South Watuppa Pond, and of Sawdy Pond, and of the streams connecting said ponds, as shown on said sheet marked "B," to a point designated as 
"Bọnd F,"' seid last point being at the most southerly end of Sawdy Pond in said line of highest water mark.

The line of "highest watermark" as 'shown on sheet B is defined by offsets at right angles to straight lines from Bound $A$, and passing respectively through points designated "B". to "F," inclusive, and on the South Watuppa Pond is also the line that would be traced by a level thirteen inches above a bolt in stonework on westerly side of : waterway in gatehouse of reservoir dam of Watuppa Reservoir Company, Quequechan River. On Sawdy Pond the highest watermark is the line that would be traced by the level of an iron bolt driven in west side of flume to sawmill at nortlierly end of said Sawdy Pond.

From Bound $\mathrm{F}$ the line runs southeasterly, being a straight line to the monument known as "Joe Sanford's bound," being the center of a copper bolt in stone on land. of Joseph Tripp, and is in latitude $41^{\circ} 35^{\prime} 37^{\prime \prime}$, longitude $71^{\circ} 08^{\prime} 13^{\prime \prime}$.

; From Joe Sanford's bound the line runs southerly, following the westerly line of the town of Westport to the Atlantic Ocean, passing easterly of Quicksand Pond through the center of a bound known as Peaked Rock; situated in latitude $41^{\circ} 29^{\prime} 58^{\prime \prime}$, longitude $71^{\circ} 07^{\prime} \cdot 34^{\prime \prime}$.

The first point in this line southerly of Sanford's bound is on the north side of milldam at Adamsville, 85.58 feet easterly of straight line from Sanford's to Peaked Rock.'

The second is 113.94 feet easterly of said straight line, and is on the easterly side. of road leading from Adamsville to the ocean.

- The third is 234.48 feet east of said straight line, on the road leading to Little Compton; by Philip Simmons' house.

The whole of the line thus described is shown on a plan herewith presented, which; with sketches $\mathrm{A}$ and $\mathrm{B}$, is made a part of this report and attested.

It will be observed that the above decree of the United States Supreme Court makes no reference to the line from Burnt Swamp Corner to the Connecticut line.

It will also be remembered (vide p: 62) that the "line of 1848 ," so called, was ratitied by Rhode Island and rejected by Massachusetts. In 1865 the legislature of Massachusetts took action in regard to this portion of the line, as follows, viz:

Resolved, That the boundary line between the State of Rhode Island and the Commonwealth of Massachusetts, from the line of the State of Connecticut to Burnt Swamp Corner, begins at the north west corner of the State of Rhode Island on the Connecticut line, in latitude $42^{\circ} 00^{\prime} 29^{\prime \prime}$ north, and longitude $74^{\circ} 48^{\prime} 18^{\prime \prime}$ west of Greenwich, ${ }^{a}$ and runs in a straight line 21 and $\frac{512}{1000}$ miles to Burnt Swamp Corner, in Wrentham, being in latitude $42^{\circ} 1^{\prime} 8^{\prime \prime}$ and longitude $71^{\circ} 23^{\prime} 13^{\prime \prime}$.

This is the line agreed upon by the commissioners, called the "line of 1848," ratified at the time by Rhode Island, but rejected by Massachusetts.

The tardy ratification of the line by Massachusetts was, in its turn, rejected by Rhode Island, on the ground that the then recent settlement of the eastern boundary by the decree of the Supreme Court had so changed the aspect of the controversy that she could not consent to the adoption of the line of 1848 as her northern boundary.

a This is a clerical error. "Longitude $74^{\circ} 48^{\prime} 18^{\prime \prime}$ " should read "longitude $71^{\circ} 48^{\prime} 18^{\prime \prime} . "$ (Vide. Borden's Tables, p. 64.) 
Thus the northern boundary of Rhode Ísland was left in abeyance, or rather left in the condition prescribed by the decision of 1846 .

In June, 1880, the legislature of Rhode Island passed a resolution to remove the monuments of the "line of 1848 " and erect monuments on the jurisdictional line.

In 1881 the legislature of Massachusetts took like action.

This jurisdictional line has the same termini as the line of 1848 , but is a very irregular line, sometimes running north of a direct line and sometimes falling south of it [the extreme variations being 529.3 feet north of the line of 1848, and 129 feet south of the same]. A full and detailed description may be found in Rhode Island Acts, May, 1867, p. 6 et seq.

Also, vide Senate Document No. 14, Massachusetts, 1848 , for a full account of this controversy.

In 1713, commissioners from the province of Massachusetts Bay and Colony of Connecticut settled a line between Massachusetts and Connecticut.

By this line certain northern frontier towns were given to Massachusetts, viz,. Woodstock, Suffield, Enfield, and Somers. In 1749 the legislature of Connecticut passed a resolution that, inasmuch as the 'line had not been approved by the King, and that the two colonies had no legal right to transfer territory without the confirmation of the Crown, thế contract was yoid, and these towns were again taken under the jurisdiction of Connecticut. Massachusetts appealed to the King, and the claims of Connecticut were fully established. (See Hollister's History of Connecticut, Vol. II.)

In 1791 Massachusetts and Connecticut appointed commissioners to establish the boundary between them, but they were unable to agree.

In 1803 commissioners were appointed to complete the line, a compromise having been made concerning the line between the town of Southwick and the towns of Suffield and Granby (the cause of the disagreement of the former commissioners).

The agreement made was as follows, viz:

That the line should begin from a station 8 rods south of the sointhwest corner of West Springfield, and thence run west to the large ponds, and thence southerly by those ponds to the ancient south line of Westfield, and from thence on said south line to the ancient southwest corner of Westfield; and from thence northerly in the ancient west line of Westfield to the station in said west line made by commissioners in the year 1714, and from thence to the southwest corner of Granville. (See Mass. Special Laws, Vol. III, page 234.)

In 1803 the commissioners surveyed and marked the boundary between their respective States.

Their report, which was adopted, is as follows, viz:

Beginning at the northeast corner of Suffield and the southeast corner of West Springfield, on the west bank of Connecticut River, at a point 75 links northward of 
the center of a small valley running into said river, said point being between a small butternut tree, marked M.C., standing on the south, and a small crooked white oak, marked M., standing on the north, about two feet distant from each other, and then run north $82^{\circ} 45^{\prime}$ west 1 chain to a stone monument erected by us there; in the same course 22 chains 25 links to a stone monument on the stage road from Springfield to Suffield, and said course continued would pass two feet north of Smith's house; thence north $82^{\circ}$ west 82 chains 3 links to a stone monument on the middle road from Suffield to Springfield; then in the same course 13 chains 30 links to a large black or red oak tree, marked on the east side $\mathrm{C}$., and on the west side $\mathrm{M}$., being an ancient bound; thence north $77^{\circ} 4^{\prime}$ west 134 chains 42 links to a stone monument on the road from Feeding Hills meetinghouse to Suffield; thence in the same course 4 chains 21 links to a pine stump-an old monument; thence north $79^{\circ} 48^{\prime}$ west 102 chains 80 links to a stone monument on the road from Westfield to Suffield, called the back street; thence north $81^{\circ} 30^{\prime}$ west 61 chains 20 links to a stone monument at an old stump and stones, the ancient southwest corner of West Springfield; thence south $5^{\circ}$ west 2 chains to a stone monument in the line run by commissioners in 1714; thence north $85^{\circ}$ west 167 chains 33 links to a stone monument at the middle pond, 22 links east of low-water mark, being at the center of a little valley running into said pond; thence on the eastern shore of said pond, as the same runs southerly, to a sluiceway or outlet from said pond to the south pond; thence southerly on the east shore of the south pond as the same runs to a stone monument at high-water mark on the south corner of said pond, being the south end of the most southerly bay thereof, from which the point of land beyond the bay on the east side of the pond bears north $29^{\circ}$ east, and the high point beyond the bay on the west side of the pond is north $3^{\circ} 30^{\prime}$ east; then south $10^{\circ} 20^{\prime}$ west 24 chains 78 links to a stone monument at the southeast corner of South wick, in the ancient south line of Westfield, from which the highest peak of Manatick Mountain bears south $42^{\circ} 30^{\prime}$ west; thence south $87^{\circ} 30^{\prime}$ west 33 chains 86 links to a heap of stones in a hedge, being an ancient monument in the south line of Westfield and the northwest corner of Suffield, adjoining Granby; thence in said ancient south line of Westfield the same course to a stone monument at a white oak stump, an old monument, the southwest corner of Southwick, being 174 chains 36 links; thence north $10^{\circ} 20^{\prime}$ east 212 chains 84 links to a stone monument erected by us, at a place in the ancient west line of Westfield, where commissioners in 1.714 established the monument called the Crank monument; thence north $82^{\circ} 17^{\prime}$ west 137 chains to a stone monument erected by us at the east road from Granby to Granville; in this course, at the distance of 86 chains 20 links from the Crank monument, we passed between two pillars of stones 45 links south of one and 13 links north of the other, both said to be the southeast corner of Granville; thence on the same course 61 chains 40 links to a stone monument erected by us on the Granby turnpike road; thence in the same course 44 chains to a white oak $a$ tree, marked by commissioners in 1717 , and which we marked M on the north side and C, 1803, on the south side; thence north $84^{\circ} 24^{\prime}$ west 5 chains 13 links to a stone monument erected by us on the west road from Granby to Granville; thence in the same course 200 chains 37 links to a white elm stump and stones on the west bank of Valley Brook, so called, a monument, made by commissioners in 1717 in this course three monuments are mentioned by said commissioners, which we do not find; thence north $85^{\circ} 7^{\prime}$ west 60 chains 15 links to a stone monument erected by us at a new road near the east bank of Hubbard River; thence the same course 2 chains to dry hemlock tree with stones about it on the west side of said river near a small fall and a rock on the east side of said river stooping towards it more than 2 rods to a monument erected by said former commissioners; thenc : north $82^{\circ} 52^{\prime}$ west 109 chains 35 links to a stone monument ${ }^{b}$ erected by us on the road from Granville 
to Hartland; thence the same course 275 chains 91 links to a large heap. of stones on the west bank of Slocum Brook between two hemlock trees, having many ancient and modern marks thereon, being a monument made by said former commissioners (in this course the commissioners of 1717 made mention of a large hemlock tree, and a very large white-ash tree which we do not find); thence north $811^{\circ} 50^{\prime}$ west 93 chains 74 links to a stone monument erected by us on the Beach-hill road, so called; thence in the same course 235 chains to a stone monument erected by us at a heap of stones about an elm tree standing on the west bank of Sandy Brook, a monument made by said former commissioners, who mentioned in their report a monument in this course, which we do not find; thence north $82^{\circ} 11^{\prime}$ west 357 chains 30 links to a stone monument erected by us on the road from Marlborough to Norfolk; thence same course 38 chains 20 links to a monument made by said former commissioners on the west bank of Whiting River, near falls, being a heap of flat stones on a large rock; thence north $82^{\circ} 9^{\prime}$ west 219 chains to a stone monument at the end of Greenwood Turnpike road (in this course said former commissioners marked two trees, which we do not find); thence in the same course 161 chains 75 links to a stone monument at the Burrell road, so called, leading from Canaan to Suffield; thence in the same course 49 chains to an elm tree, with stones near it, on the east bank of Housatonic River, about six rods west from a chestnut stump and stones, a monument made by said former commissioners, who also marked a white oak tree in this course which we do not find; thence north $82^{\circ} 52^{\prime}$ west 20 chains 50 links to a stone monument erected by us at the road leading from Salisbury to Sheffield, called Wetany road; thence in the same course 119 chains 50 links to a stone monument erected by us at the road from Salisbury to Sheffield, near Ebenezer Fletcher's house; thence on the 'same course 211 chaing 35 links to a stone monument erected by us at the mountain road from Salisbury to Sheffield; thence on the same course 28 chains 4 links to a monument established by said former commissioners at the foot of the mountain, being a heap of stones on a large rock, 20 links long on the northeasterly side, 5 feet high on the southerly side, and which we marked 1803 on the southerly side; thence north $85^{\circ} 30^{\prime}$ west 147 chains 20 links to a stone monument erected by us on the road from Salisbury to Mount Washington; thence on the same course 81 chains 80 links to a large heap of stones, the oblong corner bounds, so called, between the State of Connecticut and New York.

The courses of said line as before given, and here by us are according to the present state of magnetic needle, which we observed to vary $5^{\circ}$ west of north. (See Private laws of Conn., vol. 2, pages 1540 to 1544.)

ABSTRACT OF REPORT OF COMMISSION OF 1803 ON BOUNDARY BETWEEN MASSACHUSETTS AND CONNECTICUT WEST OF THE CONNECTICUT RIVER.

Beginning at a point on the west bank of Connecticut River, in latitude $42^{\circ} 01^{\prime}$ $52^{\prime \prime} .10$, longitude $72^{\circ} 37^{\prime} 03^{\prime \prime} .46$, and running north $82^{\circ} 45^{\prime}$ west 22 chains 25 links; thence north $82^{\circ}$ west 95 chains 33 links; thence north $77^{\circ} 4^{\prime}$ west 138 chains 63 links; thence north $79^{\circ} 48^{\prime}$ west 102 chains 80 links; thence north $81^{\circ} 30^{\prime}$ west 61 chains 20 links; thence south $5^{\circ}$ west 2 chains; thence north $85^{\circ}$ west 167 chains 33 links to a stone monument at the middle pond, 22 links east of low-water mark, latitude $42^{\circ} 02^{\prime} 11^{\prime \prime}$, longitude $72^{\circ} 45^{\prime} 45^{\prime \prime} .07$; thence southerly along the east shore of said pond, and also south pond, to a stone -monument at high-water mark, at the south corner of said south pond; thence south $10^{\circ} 20^{\prime}$ west 24 chains 78 links to a stone monument at southeast corner of South wick, which is in latitude $42^{\circ} 00^{\prime} 11^{\prime \prime} .98$, longitude $72^{\circ} 46^{\prime} 24^{\prime \prime} .23$; thence south $87^{\circ} 30^{\prime}$ west 208 chains 22 links to a stone monument at the southwest corner of South wick, which is in latitude $41^{\circ} 59^{\prime} 51^{\prime \prime} .89$, longitude $72^{\circ} 49^{\prime} 25^{\prime \prime} .47$; thence north $10^{\circ} 20^{\prime}$ east 212 chains 84 links to a stone monument at the northwest corner of the South wick Jog, which is in latitude $42^{\circ} 02^{\prime}$ 
$12^{\prime \prime} .39$, longitude $72^{\circ} 49^{\prime} 13^{\prime \prime} .51$; thence north $82^{\circ} 17^{\prime}$ west 242 chains 40 links to a white oak tree, marked by commissioners in 1717 , which is in latitude $42^{\circ} 02^{\prime} 15^{\prime \prime} .84$, longitude $72^{\circ} 52^{\prime} 47^{\prime \prime} .74$; thence north $84^{\circ} 24^{\prime}$ west 205 chains 50 links; thence north $85^{\circ} 7^{\prime}$ west 62 chains 15 links; thence north $82^{\circ} 52^{\prime}$ west 109 chains 35 links to a stone monument in latitude $42^{\circ} 02^{\prime} 17^{\prime \prime} .03$, longitude $72^{\circ} 58^{\prime} 22^{\prime \prime} .52$; thence north $82^{\circ}$ $52^{\prime}$ west 275 chains 91 links; thence north $81^{\circ} 45^{\prime}$ west 70 chains; thence north $81^{\circ}$ $50^{\prime}$ west $328^{\circ}$ chains 74 links to a stone monument, which is in latitude $42^{\circ} 02^{\prime} 31^{\prime \prime} .11$, longitude $73^{\circ} 07^{\prime} 35^{\prime \prime} .94 ;$; thence north $82^{\circ} 11^{\prime}$ west 395 chains 50 links; thence north $82^{\circ} 9^{\prime}$ west 430 chains; thence north $82^{\circ} 52^{\prime}$ west 140 chains to a stone monument on the road from Salisbury to Sheffield, which is in latitude $42^{\circ} 02^{\prime} 58^{\prime \prime} .11$, longitude $73^{\circ} 22^{\prime} 55^{\prime \prime} .27$; thence north $82^{\circ} 52^{\prime}$ west 239 chains 39 links; thence north $85^{\circ} 30^{\prime}$ west 239 chains to the north west corner of Connecticut, which is in latitude $42^{\circ} 02^{\prime}$ $58^{\prime \prime} .54$, longitude $73^{\circ} 30^{\prime} 06^{\prime \prime} .66$.

According to the survey of the cession of Boston Corners, by Massachusetts to New York, in 1855, the south boundary of Massachusetts from the northwest corner of Connecticut to the southwest corner of Massachusetts is as follows, viz:

A line running north $89^{\circ} .08^{\prime} 4^{\prime \prime}$ west, 40 chains, by the true meridian. The courses of the line of 1803 are magnetic, with the variation as at that date, i. e., $5^{\circ}$ west.

The latitudes and longitudes in the foregoing are taken from the Borden Trigonometrical Survey of Massachusetts of 1843.

In 1826 the line between Massachusetts and Connecticut east of the Connecticut River was run by commissioners appointed from each State. An abstract of the commissioners' report is here given:

Abstract of report of commissioners of 1826. - The commissioners first made the following survey: Commencing at the northeast corner of Connecticut, at a large pile of stones erected by commissioners of 1734 ; thence running due west on the latitude of $42^{c} 3^{\prime}$ north to the west line of Woodstock, 15 miles 169 rods 15 links. (This is hereafter referred to as the "first line of latitude.") Thence north $3^{\circ}$ west 54 rods 19 links to an old pine tree, the reputed northeast corner of Union; thence due west 25 miles 168 rods to Connecticut River. (This line is hereinafter referred to as the "second line of latitude," and the second line of latitude is 54 rods north of the first.) These lines of latitude were compared with the ancient survey, monuments, evidence, etc., of the line run by the commissioners of 1713; the said lines of latitude were found to vary in sundry places therefrom. Therefore, in order to conform as near as possible to the line of 1713 , the line was run as follows, viz:

Beginning at the northeast corner of Connecticut and running west on "first line of latitude" 1,702 rods and 4 links to the road to the Merino road; thence in a direct line 1,372 rods 20 links to the road leading from Muddy Brook, so called, by Pennel May's to Southbridge; this point is 21 rods 10 links north of the "first line of latitude;" thence in a direct line 360 rods 5 links to the Norwich and Woodstock turnpike (this point is 20 rods and 5 links north of "first line of lati. 


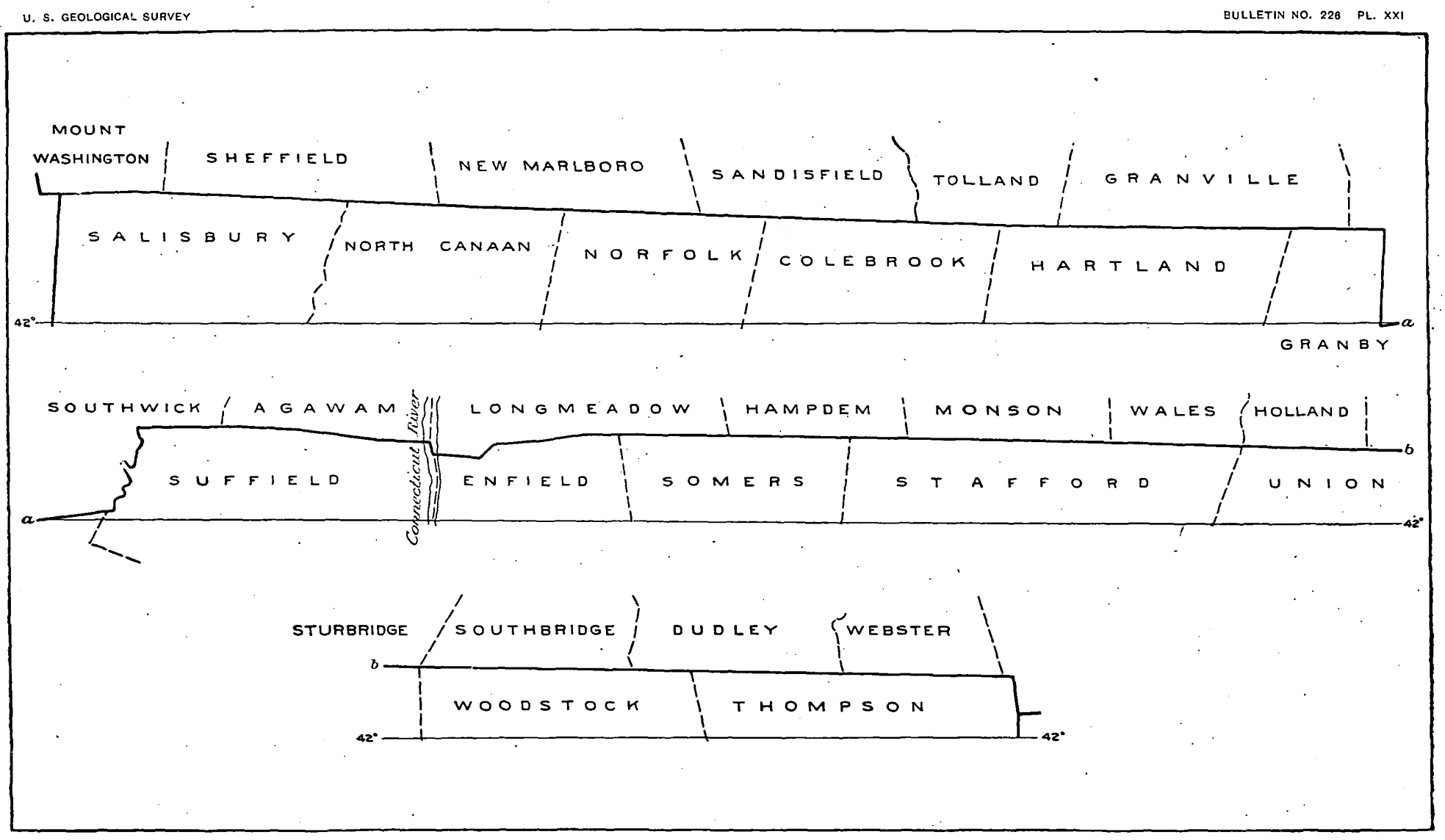

BOUNDARY BETWEEN MASSACHUSETTS AND CONNECTICUT. 
tude"); thence in a direct line 954 rods 18 links to the road leading from West Woodstock by Abel Mason's to Southbridge (this point is 10 rods and 22 links north of "first line of latitude"); thence in a direct line 1,247 rods to the road leading from. Union by Asher Bodgen's to Holland (this point is 2 rods $14 \frac{3}{4}$ links south of "second line of latitude"); thence in a direct line 1,127 rods to the turnpike from Hertford, through Stafford and Holland, to Worcester (this point is 6 rods $23 \frac{1}{2}$ links south of the "second line of latitude"); thence in a direct line 467 rods to an old white oak tree, an ancient bound, on the road from Stafford by Robert Andruss' to South Brimfield (this point is 1 rod 2 links south of "second line of latitude"); thence in a direct line of 1,615 rods to the road leading from Stafford by Henry Cady's to Monson (this point is 16 rods 15 links south of "second line of latitude"); thence in a direct line 256 rods to the Tracy road (this point is 12 rods 12 links south of "second line of latitude"); thence in a direct line 620 rods to the road leading from Stafford by Seth Sheldon's to South Wilbraham (this point is 14 rods 7 links south of "second line of latitude"); thence in a direct line 1,066 rods to the road from Somer's by Walter Ainsworth's to Springfield (this point is 4 rods 1 link north of "second line of latitude"); thence in a direct line 523 rods to the road from Somer's by Abel Peas's to Springfield (this point is 6 rods 12 links south of the "second line of latitude"); thence due west 645 rods to the ancient line between Springfield (now Long Meadow) and Enfield; thence south $80^{\circ} 30^{\prime}$ west by the true meridian 645 rods to a monument at an old oak stump; thence south $51^{\circ} 30^{\prime}$ west by the true meridian 164 rods 18 links to a monument at an old pine stump; thence due west 349 rods 15 links to a monument on the Connecticut River 12 rods from the shore; thence due west to the Connecticut River. On the line are erected 49 monument stones, marked on the north side $\mathrm{M}$ and on the south side $\mathrm{C}$.

The commissioners also surveyed and marked the line from the corner of Connecticut to the corner of Rhode Island, reporting as follows:

Beginnir.g at the monument erected at the northeast corner of said State of Connecticut and running in a direct line to the ancient heap of stones on the north side of the turnpike leading from Hertford to Boston, through Thompson and Douglass, where we erected a monument, and thence running in a direct line to the northwest corner of the State of Rhode Island.

(For survey of 1826, see Private Laws of Conn., vol. 2, pages 1544 to 1550 .)

The boundary between Massachusetts and New York at an early period became a subject of bitter dispute, New York claiming to the west bank of the Connecticut River, under the charters of 1664 and 1674 to the Duke of York, Massachusetts claiming, under her old charters, to the South Sea. After many fruitless attempts at a settle- 
ment, an arraingement was entered into in '1773 fixing the western boưhilary of Massachusetts where it meets New York territory. The Revolution following soon after, the line was not run. In 1785 Congress appointed three commissioners to run the line, who performed that duty in 1787. The line was as follows, viz:

Beginning at a monument erected in 1731 by commissioners from Connecticut and New York, distant from the Hudson River 20 miles, and running north $15^{\circ} 12^{\prime} 9^{\prime \prime}$, east 50 miles 41 chainsand 79,1 inks, to a red or black oak tree marked by said commissioners, which said line was run as the magnetic needle pointed in 1787.: (Vide Revised Statutes of New York, 1875, p. 122.)

The claims of Massachusetts to western lands were finally settled December 16,1786 , by a joint commission of the two. States. : By this agreement Massachusetts surrendeied the sovereignty of the whole disputed territory to New York, and received in return the right of soil and preemption right of Indian purchase west of the meridianpassing through the eighty-second mile-stone of the Pennsylvania line, excepting certain reservations upon Niagara River. 'The title to a tract known as "The Boston .Ten Towns," lying east of this meridian, previously granted by Massachusetts, was also confirmed. '(Tide Hough's N.' Y. Gaz., 1872, pp. 25, 26.)

April 19, 1785, Massachusetts executed a deed to the United States: It included all title of the State of Massachusetts to territory west of the present western boundary of New York.

In 1820 Maine, hitherto a part of Massachusetts, was admitted into the Union as an independent State.

In 1853 a small portion of territory in the southwestern corner of Massachusetts, known as Boston Corner, was ceded to New York, and the cession confirmed by Congress in 1855 .

The cession of Boston Corner to New York changes the boundary, so that it is now as follows, viz:

Beginning at a monument erected in 1731 by commissioners from Connecticut and New York (known as the Connecticut monument); standing in the south boundary of Massachusetts, latitude $42^{\circ} 02^{\prime} 58^{\prime \prime} .54$, longitude $73^{\circ} 30^{\prime} 06^{\prime \prime} .66$, which is the northwest corner of the State of Connecticut; thence along the south boundary of Massachusetts, north $89^{\circ} 08^{\prime} 41^{\prime \prime}$ west, 40 chains; thence north $12^{\circ} 57^{\prime} ; 16^{\prime \prime}$ west $207.49^{\circ}$ chains to a marble post marked on the east side M. S., on the west side $\mathrm{N}$. Y., and on the south side 1853 , which is in the line run by United States commissioners in 1787 ; thence north $15^{\circ} 12^{\prime} 9^{\prime \prime}$ east on the line run by said United States commissioners ( ${ }^{a} 47$ miles $73.70^{5}$ chains) to a red or black oak tree marked by said United States commissioners, in the south boundary of the State of Vermont; latitude $42^{\circ} 44^{\prime}$

a This distance has been obtained by subtracting the length of the west line of Boston Corner given in survey of 1853 from the entire length of west boundary of Massachusetts as given by the United States commissioners in 1787. 
$45^{\prime \prime}: 48$, longitude $73^{\circ} 16^{\prime} 17^{\prime \prime} .68$. [See. Revised Statutes of New York, 1875 , page 122; also plat of survey of Boston Corner in 1853, a copy of which is on file in office of clerk of House of Representatives at Washington; D. C.]

\section{RHODE ISLAND.}

The present State of Rhode Island was settled by Roger Williams and other immigrants, who left Massachusetts Bay and established themselves at Providence in 1636.

In 1643 a patent was granted for the Providence Plantation, from which the following are extracts, viz:

.. * * * * * * * * *

- zatud wheras there is a tract of land in the continent of America aforesaid, called by thimame of the Narraganset.Bay, bordering north ward and northeast on the patent of the Massachusetts, east and southeast on Plymouth patent, south on the ocean, and on the west and northwest by the Indians called Narigganneucks, alias Narragansets, the whole tract extending about 25 English miles unto the Pequot River and country; and wheras divers English inhabitants of the towns of Providence, Portsmouth, and Newport, in the tract aforesaid, *** have represented their desire, $* * *$ we * * * do * * * give, grant, and confirm to the aforesaid inhabitants of the towns of Providence, Portsmouth, and Newport a firm and absolute charter of incorporation, to be known by the name of the incorporation of Providence Plantations, in the Narraganset Bay, in New England.

In 1663 Charles II granted a charter to Rhode Island and Providence Plantations, of which the following is an extract:

* * * "All that parte of our dominiones in New-England, in America, conteyneing the Nahantick and NarragansettBay, and countryes and partes adjacent, bounded on the west, or westerly, to the middle or channel of a river there, commonly called and known by the name of Pawcatuck, alias Pawcawtuck river, and soe along the sayd river, as the greater or middle streame thereof reacheth or lyes upp into the north countrye, northward, unto the head thereof, and from thence, by a streight lyne drawn due north until itt meets with the south lyne of the Massachusetts Collony; and on the north, or northerly, by the aforesayd south or southerly lyne of the Massachusetts Collony or Plantation, and extending towards the east, or eastwardly, three English miles to the east and north-east of the most eastern and northeastern parts of the aforesayd Narragansett Bay, as the sayd bay lyeth or extendeth itself from the ocean on the south, or south wardly, unto the mouth of the river which runneth towards the towne of Providence, and from thence along the eastwardly side or banke of the sayd river (higher called by the name of Seacunck river), up to the ffalls called Patuckett ffalls, being the most westwardly lyne of Plymouth Collony, and soe from the sayd ffalls; in a streight lyne, due north, untill itt meet with the aforesayd line of the Massachusetts Collony; and bounded on the south by the ocean." And in particular, the lands belonging to the townes of Providence, Pawtuxet, Worwicke, Nusquammack, alias Pawcatuck, and the rest upon the main land in the tract aforesayd together with Rhode Island, Blocke Island, and all the rest of the islands and banks in the Narragansett Bay and bordering upon the coast of the tracts aforesaid (Fishers Island only excepted).

(For history of the northern and eastern boundaries see Massachusetts, p. .54:)

In 1703 substantially the present western boundary was settled by an agreement made between the commissioners from the two colonies 
of Rhode Island and Connecticut, viz: "A straight line from the mouth of Ashawoga River to the southwest corner of the Warwick purchase, and thence a straight north line to Massachusetts.

The line of 1703 was actually run by Rhode Island, and is still known as the Dexter and Hopkins line.

The two colonies disagreeing, Rhode Island appealed to the King, and the agreement of 1703 was finally established in 1726 .

In September, 1728, commissioners from the two colonies met and ran the line.

(For agreement of 1703 and 1728, decisions of English council, etc., see R. I. Hist. Soc. Coll., Vol. III.)

In 1839 commissioners were appointed by hhode Island and Connecticut to survey and ascertain the line and erect monuments.

The following line was established, viz:

Beginning at a rock near the mouth of Ashawoga River, where it empties into Pawcatuck River, and from said rock a straight course northerly to an ancient stone heap at the southeast corner of the town of Voluntown, and from said rock southerly in the same course with the aforesaid line, until it strikes Pawcatuck River. From the southeast corner of Voluntown a straight line to a stone heap at the southwest corner of West Greenwich; from thence a straight line to the south west corner of the ancient town of Warwick, and which is now a corner of the towns of Coventry and West Greenwich; from thence a straight line to the northwest corner of the town of Coventry; thence a straight line to the northeast corner of Sterling; thence a straight line to the southwest corner of Burrillville, and thence a straight line to a stone heap upon a hill in the present jurisdictional line between the States of Massachusetts and Rhode Island, and at all of said corners, excepting said Warwick corner, we have erected monuments of stone, marked R. I. and C., and have also placed similar monuments on all the principal roads crossing the line, and at other suitable places.

And we have caused the ancient monument which was erected at the Warwick corner in November, 1742, to be reset and a large heap of stones to be made around it. Said monument is marked with the letter C. on one side, and on the other RHODE. I S L A N D and the traces of other letters and figures. [Extract from Commissioner's Report. See R. I. Acts and Resolves, Jan. 1846, pages 12, 13, 14.]

The above was ratified in 1846 .

\section{CONNECTICUT.}

The title by which the people of Connecticut held the country was founded on the old patent granted by Robert, Earl of Warwick, in 1631, to Lord Say and Seal, Lord Brooke, Sir Richard Saltonstall, and others, associated under the name of the Plymouth Company.

In 1630-the Plymouth Council made a grant of Connecticut to the Earl of Warwick, their president. This was confirmed by King Charles in 1631, and on the 19th of March, in the same year, the Earl conveyed his title to the Plymouth Company, as before stated. (Dwight's Conn., p. 19, et seq.)

A charter was granted by Charles II to Connecticut in 1662, of which the following is an extract, viz: 


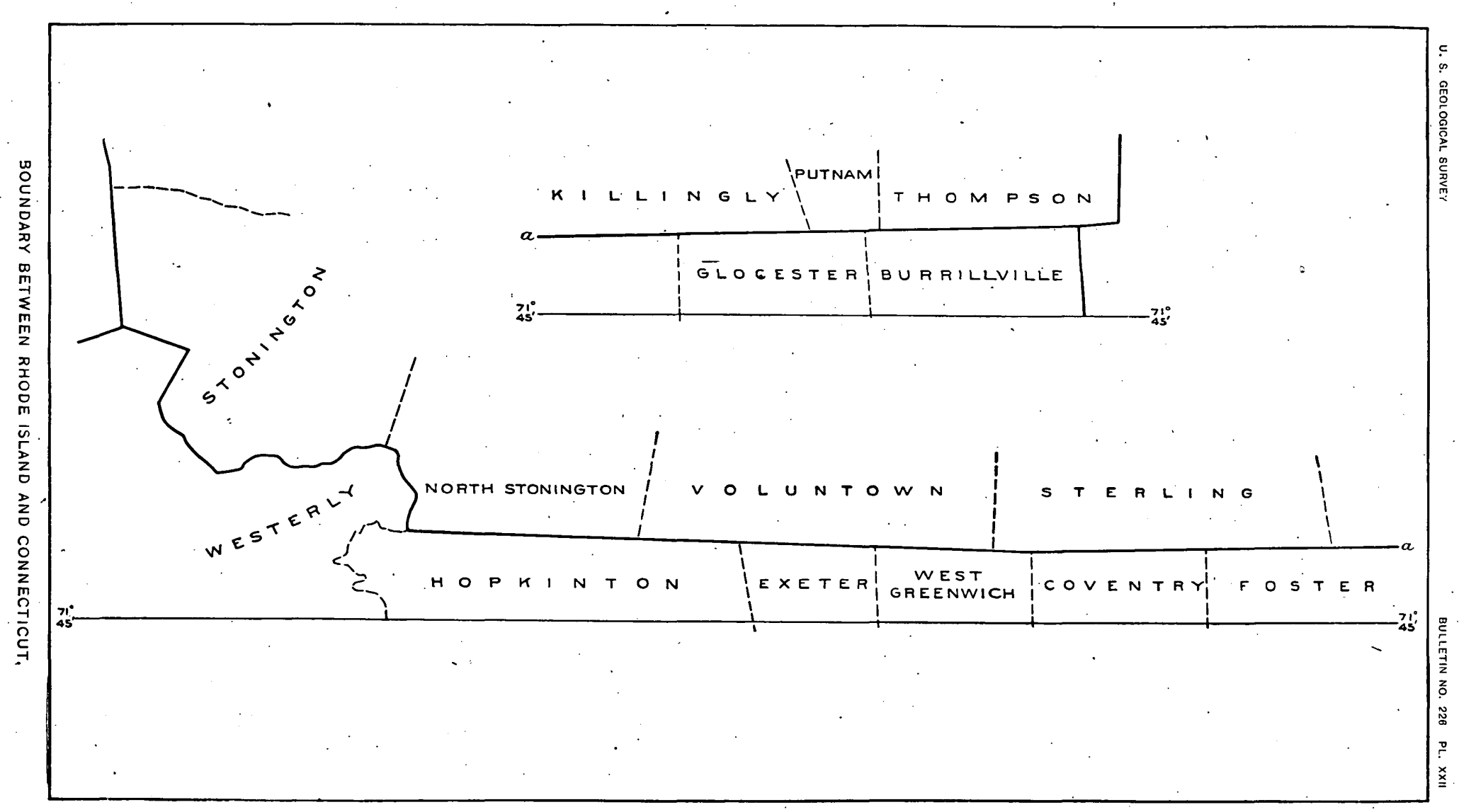


$*$

We *** do give, grant and confirm unto the said Governor and Company, and their successors, all that part of our Dominions in New England in America bounded on the east by Narraganset River, commonly called Narraganset Bay, where the said river falleth into the sea, and on the north by the line of the Massachusetts plantation; and on the south by the sea; and longitude as the line of the Massachusetts Colony, running from east to west, that is to say, from the said Narraganset Bay on the east, to the south sea on the west part, with the islands thereunto adjoining. * *

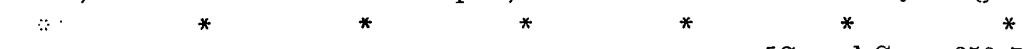

[C. and C., p. 256-7.]

Previous to this time the two colonies of Connecticut and New Haven had continued separate, but under this charter they were united and the charter was accepted April 20, 1665. (C. and C., p. 252.)

The Duke of York having been granted a charter in 1664, by which the lands west of the Connecticut River were embraced in his jurisdiction, the question of boundary immediately arose.

About this time Col. Richard Nichols, George Cartwright, esq., Sir Robert Carr, and Samuel Maverick, esq., had been appointed commissioners by the King, and clothed with extraordinary powers, to determine all controversies in the colonies. The matter was referred to them, who, after a full hearing, determined that the southern boundary of Connecticut was the sea (Long Island Sound), and its western, Mamaroneck River, and a line drawn north-northwest from the head of salt water in it to Massachusetts. The territory south and west of these lines was declared to belong to the Duke of York. (Vide Dwight's Connecticut, pp. 159 et seq.)

This decision in effect, decided upon a line 20 miles east of the Hudson River as the boundary, having for a starting point a place on Mamaroneck River.

In 1674 the Duke of York received a new charter in substantially the same terms as that of 1664 . New controversies concerning jurisdiction led to a new agreement, by which it was stipulated that a tract of land on Long Island Sound, the bounds of which were described as containing 61,440 acres, should be permanently set off to Connecticut by New York on condition that the former, in exchange, should set off to New York a territory of like extent and of uniform width from the tract on the Sound to the south line of Massachusetts. This agreement was sanctioned by a royal ordinance of the King, and in 1684 the tract on the Sound was surveyed and set off to Connecticut.

The western boundary of Connecticut was run in 1685 by Major Gould, Mr. Barr, and Mr. Selleck, and ratified by both parties. (Vide Dwight's Connecticut, p. 199.)

For various reasons the survey of the equivalent lands was not made at that time.

In 1725 commissioners were appointed on both sides to tix the line, this being the fifth set appointed for the same purpose, none of which had been able to come to an agreement.

Bull. 226-04-8 
The commissioners of 1725 , however, entered into articles of agreement settling the manner of the survey. They, however, ran only the line bounding the tract on Long Island Sound.

For some cause action was then suspended until 1731, when the commissioners of 1725 surveyed and set off the oblong or equivalent territory to New York, defining and marking its boundary, which was to remain forever the dividing line between the respective States (then colonies). The line was substantially as at present, and is as follows, viz:

Beginning at Lyon's Point, in the mouth of a brook or river called Byram's River, where it falls into Long Island Sound, and running thence up along said river to a rock at the ancient road or wading place in said river, which rock bears north twelve degrees and forty-five minutes east, five hundred and fifty rods from said point; then north twenty-three degrees and forty-five minutes west, two thousand two hundred and ninety-two rods; then east-northeast, thirteen miles and sixty-four rods, which lines were established in the year one thousand seven hundred and twenty-five, by Francis Harrison, Cadwaller Colden, and Isaac Hicks, commissioners on the part of the then province of New York, and Jonathan Law, Samuel Eells, Roger Walcott, John Copp, and Edmund Lewis, commissioners on the part of the then colony of Connecticut, and were run as the magnetic needle then pointed; then along an east-northeast continuation of the last-mentioned course, one mile, threequarters of a mile, and twenty-one rods, to a monument erected in the year one thousand seven hundred and thirty-one by Cadwaller Colden, Gilbert Willett, Vincent Matthews, and Jacobus Bruyn, jr., commissioners on the part of said province, and Samuel Eells, Roger Walcott, and Edmund Lewis, commissioners on the part of said colony, which said monument is at the southeast corner of a tract known and distinguished as the oblong or equivalent lands; then north twenty-four degrees and thirty minutes west, until intersected by a line run by said last-mentioned commissioners, on a course south twelve degrees and thirty minutes west, from a monument erected by them in the south bounds of Massachusetts, which monument stands in a valley in the Taghkanick Mountains, one hundred and twenty-one rods eastward from a heap of stones in said bounds, on the top or ridge of the most westerly of said mountains; then north twelve degrees and thirty minutes east from a monument erected by said last-mentioned commissioners at said place of intersection, and standing on the north side of a hill, southeasterly from the eastermmost end of the long pond, along the aforesaid line to the aforesaid monument erected in the south bounds of Massachusetts-being the northeast corner of the oblong. (See Revised Statutes of N. Y., 1881, Vol. I, pages 128-9.)

For more than a century no controversy arose, but subsequent to 1850 questions of jurisdiction were raised, and in 1855 Connecticut made a proposition for a new survey. Several sets of commissioners were appointed, but no agreement being reached, finally, in 1860, pursuant to an act of the legislature of New York, the line was run by the New York commissioners, Connecticut not being represented.

The first section of the act of the New York legislature is as follows, viz:

1. The commissioners appointed by the governor to ascertain the boundary line between the States of New York and Connecticut are hereby empowered and directed to survey and mark, with suitable monuments, the said line between the two States as fixed by the survey of 1791 . 


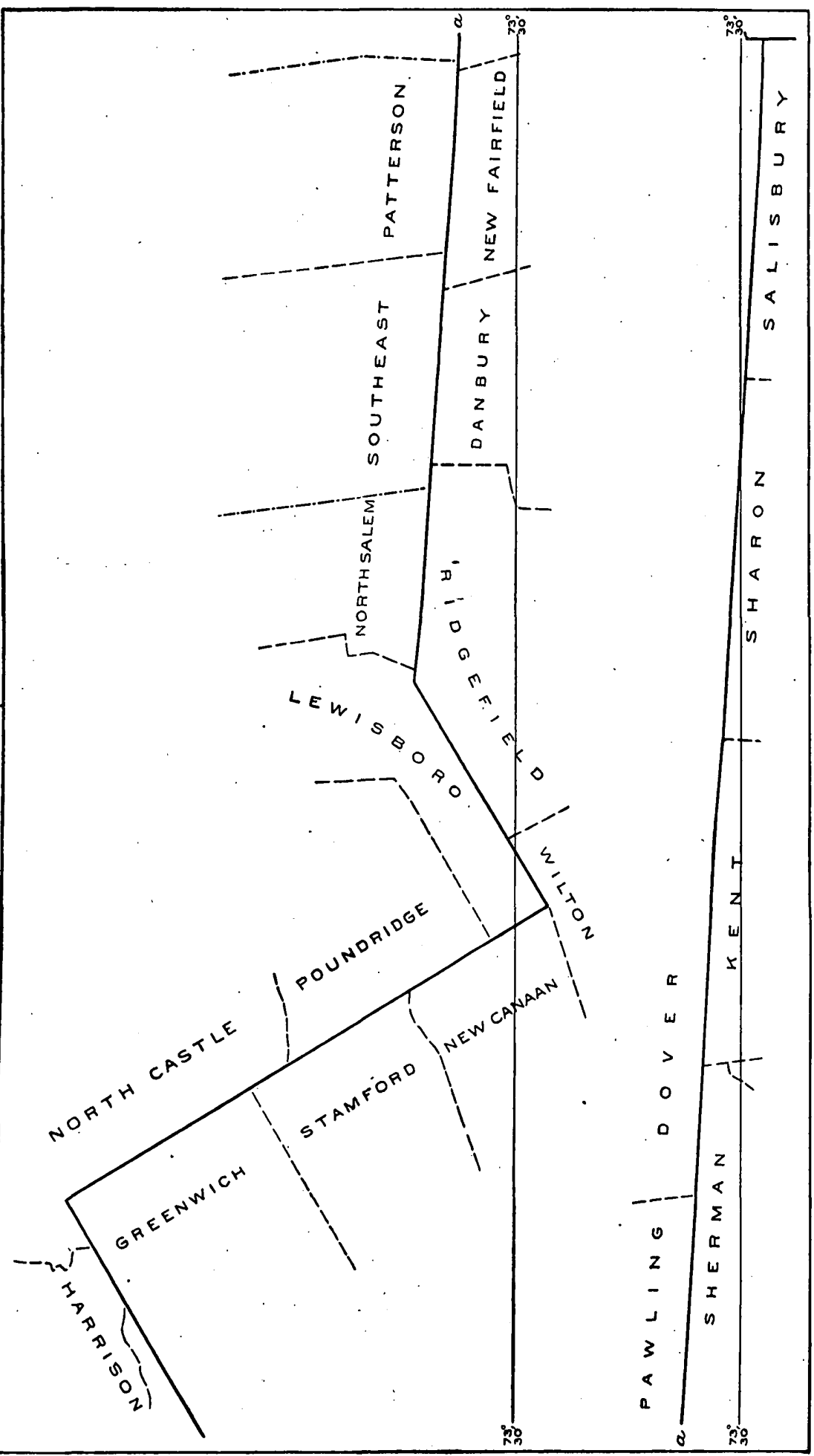


The following is an abstract of the engineer's report of the line run under direction of the commissioners from New York, the Connecticut commissioners declining to be present or assist, viz:

Beginning at the northwest corner of Connecticut, at the monument erected by the commissioners of New York and Connecticut in 1731, latitude $42^{\circ} 02^{\prime} 58^{\prime \prime} .54$, longitude $73^{\circ} 30^{\prime} 06^{\prime \prime} .66$; thence south $11^{\circ} 20^{\prime}$ west, 464 chains, to the ${ }^{a} 47$ th mile monument; thence south $12^{\circ} 34^{\prime}$ west, 239 chains 57 links, to the 44 th mile monument point; thence south $11^{\circ} 33^{\prime}$ west, 160 chains, 99 links, to the $42 \mathrm{~d}$ mile monument; thence south $13^{\circ} 16^{\prime}$ west, 161 chains 24 links, to the 40 th mile monument point; thence south $12^{\circ} ' 21^{\prime}$ west, 398 chains 21 links, to the 35 th mile monument; thence south $12^{\circ} 32^{\prime}$ west, 158 chains 96 links, to the $33 \mathrm{~d}$ mile monument; thence south $11^{\circ} 44^{\prime}$ west, 243 chains 37 links, to the 30 th mile monument; thence south $12^{\circ} 27^{\prime}$ west, 161 chains 32 links, to the 28 th mile monument; thence south $10^{\circ} 56^{\prime}$ west, 160 chains, to the 26 th mile monument point; thence south $11^{\circ} 39^{\prime}$ west, 320 chains 11 links, to the $22 \mathrm{~d}$ mile monument; thence south $12^{\circ}$ $18^{\prime}$ west, 163 chains 17 links, to the 20 th mile monument; thence south $11^{\circ} 49^{\prime}$ west, 159 chains 9 links, to the 18 th mile monument; thence south $12^{\circ} 19^{\prime}$ west, 157 chains 15 links, to the 16 th mile monument; thence south $10^{\circ} 11^{\prime}$ west, 161 chains 7 links, to the 14 th mile monument; thence south $10^{\circ} 51^{\prime}$ west, 313 chains 41 links, to the 10 th mile monument point; thence south $12^{\circ} 24^{\prime}$ west, 155 chains 71 liniss, to the 8th mile monument; thence south $10^{\circ} 19^{\prime}$ west, 159 chains 28 links, to the 6th mile monument point; thence south $12^{\circ} 10^{\prime}$ west, 164 chains 42 links, to the 4 th mile monument; thence south $11^{\circ} 44^{\prime}$ west, 158 chains 99 links, to the 2 -mile monument; thence south $14^{\circ} 10^{\prime}$ west, 109 chains 41 links, to the Ridgefield angle monument; ${ }^{b}$ thence south $25^{\circ} 8^{\prime}$ east, 213 chains 39 links, to the 4 th mile monument on the east line of the oblong between the Wilton and Ridgefield angles; thence south $24^{\circ} 48^{\prime}$ east, 157 chains 63 links, to the 2-mile monument; thence south $24^{\circ} 14^{\prime}$ east, 167 chains 28 links, to the Wilton angle monument, or southeast corner of the oblong as set off by the com missioners of 1731 ; thence south $67^{\circ} 45^{\prime}$ west, 138 chains 76 links, to the southwest corner of the oblong, and being where the survey of 1725 terminated; thence south $65^{\circ} 44^{\prime}$ west, 90 chains 87 links, to a point considered the original 12th mile monument point; thence south $66^{\circ} 56^{\prime}$ west, 241 chains 93 links, to a point called the 9th mile monument; thence south $66^{\circ} 45^{\prime}$ west, 319 chains 12 links, to the 5th mile monument point; thence south $66^{\circ} 25^{\prime}$ west, 398 chuins 40 links, to the angle at the Duke's Trees; thence south $23^{\circ} 38^{\prime}$ east, 172 chains 93

a The mile monuments referred to are those, at that time remaining, which were established by the Connecticut and New York commissioners of 1731.

$b$ The entire distance from the Massachusetts line to Ridgefield angle is 52 miles 35 rods, a difference of only 5 rods from the survey of 1731 . 
links, to a point which is west-southwest and distant 32 rods from the chimney in the old Clapp house; thence south $24^{\circ} 21^{\prime}$ east, 224 chains 78 links, to a point opposite the old William Anderson house; thence south $24^{\circ} 19^{\prime}$ east, 173 chains 7 links, to the great stone at the ancient wading place on Byram River; thence south $17^{\circ} 45^{\prime}$ west, 12 chains . 60 links, to a rock in the river which can be seen at low tide, in which there is a bolt; thence south $27^{\circ}$ west, 55 chains 19 links; thence south $7^{\circ} 20^{\prime}$ east, 13 chains 45 links; thence south $12^{\circ} 10^{\prime}$ east, 16 chains 13 links; thence south, $2^{\circ} 40^{\prime}$ east, 9 chains 4 links; thence south $28^{\circ} 25^{\prime}$ east, 9 chains 54 links; thence south $18^{\circ} 40^{\prime}$ east, 4 chains 77 links thence south $11^{\circ} 55^{\prime}$ west, 6 chains 33 links; thence south $58^{\circ} 10^{\prime}$ west, to: where it falls into the sound. (See report of the commissioners to ascertain and settle the boundary line between the States of New York and Connecticut, February 8,1861 , in which will also be found a complete account of this controversy.)

In 1880 commissioners were appointed by Connecticut and New York. Their report was ratified in 1880.

These commissioners reported as follows, viz:

We agree that the boundary on the land constituting the western boundary of Connecticut and the eastern boundary of New York shall be and is as the same was defined by monuments erected by commissioners appointed by the State of New York, and completed in the year 1860, the said boundary line extending from Byram Point, formerly called Lyon's Point, on the south, to the line of the State of Massachusetts on the north.

And we further agree that the boundary on the sound shall be and is as follows:

Beginning at a point in the center of the channel, about 600 feet south of the extreme rocks of Byram Point, marked No. 0, on appended United States Coast Survey chart; thence running in a true southeast course $3 \frac{1}{4}$ statute miles; thence in a straight line (the arc of a great circle) northeasterly to a point 4 statute miles due south of New London Light-House; thence northeasterly to a point marked No. 1, on the annexed United States Coast Survey chart of Fisher's Island Sound, which point is on the longitude east three-quarters north, sailing course down on said map, and is about 1,000 feet northerly from the Hommock or North. Dumpling LightHouse; thence following said east three-fourths north sailing course as laid down on said map easterly to a point marked No. 2 on said map; thence southeasterly to a point marked No. 3 on said map; so far as said States are coterminous. (See Revised Statutes of New York, 1881, Vol. I, page 136.)

The above agreement concerning these boundaries between Connecticut and New York was confirmed by the Congress of the United States on February 26, 1881. (See Revised Statutes of United States, 1881.)

(For the history and present location of the eastern boundary of Connecticut, vide Massachusetts, p. 61, and Rhode Island, p. 71. For the northern boundary, vide Massachusetts, p. 65.)

Under the charter of 1662 Connecticut claimed a large western territory. Subsequent to the Revolution, however, in 1786, 1792, 1795, and 1800, she relinquished all title to any land west of her present boundary. 
NEW YORK.

The territory included in the present State of New York was embraced in the French and English grants of 1603 and 1606. The Dutch, however, in 1613 established trading posts on the Hudson River and claimed jurisdiction over the territory between the Connecticut and Delaware rivers, which they called New Netherlands. The government was vested in "The United New Netherland Company," chartered in 1616, and then in "The Dutch West India Company," chartered in 1621.

In 1664 King Charles II of England granted to his brother, the Duke of York, a large territory in America, which included, with other lands, all that tract lying between the west bank of the Connecticut River and the east bank of the Delaware. The Duke of York had previously purchased, in 1663, the grant of Long Island and other islands on the New England coast, made in 1635 to the Earl of Stirling, and in 1664, with an armed fleet, he took possession of New Amsterdam, which was thenceforth called New York. This conquest was confirmed by the treaty of Breda in 1667 .

The following is an extract from the grant of 1664 to the Duke of York:

All that parte of the maine land of New England beginning at a certaine place called or knowne by the name of St. Croix next adjoyning to New Scotland in A merica and from thence extending along the sè coast unto a certain place called Petuaquine or Pemaguid and so up the River thereof to the further head of ye same as it tendeth north wards and extending from thence to the River Kinebequi and so upwards by the shortest course to the River Canada northward and also all that Island or Islands commonly called by the severall name or names of Matowacks or Long Island scituate lying and being towards the west of Cape Codd and ye narrow Higansetts abutting upon the maine land between the two Rivers there called or knowne by the severall names of Conecticutt and Hudsons River togather also with the said river of Hudsons River and all the land from the west side of Conecticutt to ye east side of Delaware Bay and also all those severall Islands called, or knowne by the names of Martin's Vinyard and Nantukes otherwise Nantuckett togather with all ye lands islands soyles harbours mines minerals quarryes woods marshes waters lakes ffishings hawking hunting and ffowling and all other royalltyes proffitts commodityes and hereditaments to the said severale island lands and premisses belonging and appertaining with theire and every of theire appurtenances and all our estate right title interest benefitt advantage claime and demand of in or to the said lands and premises or any part or parcell thereof and the revercon and revercons remainder and remainders togather with the yearly and other ye rents revenues and proffitts of all and singular the said premisses and of every part and parcell thereof to have and to hold all and singular the said lands islands hereditaments and premisses with their and every of their appurtenances.

In July, 1673, the Dutch recaptured New York and held it until it was restored to the English by the treaty of Westminster, in February, 1674.

The Duke of York thereupon, to perfect his title, obtained a new 
grant in substantially the same terms as that of 1664 (C. and C., p. 1328), of which the following is an extract, viz:

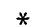

All that part of the mainland of New England, beginning at a certain place called or known by the name of Saint Croix nexe adjoining to New Scotland in America, and from thence extending along the sea-coast into a certain place called Petuaquim or Pemquid, and so up the river thereof to the furthest head of the same as it windeth northward and extending from the river of Kinebequ and so upwards by the shortest course to the river Canada northwards; and all that island or islands commonly called by the several name or names of Matowacks or Long Islands, situate and being toward the west of Cape Cod and the narrow Higansuts abutting upon the mainland between the two rivers there called or known by the several names of Connecticut and Hudson Rivers, together also with the said river called Hudson's River, and all the lands from the west side of Connecticut River to the east side of Delaware Bay; and also all those several islands called or known by the names of Martin Vinyard and Nantukes, otherwise Nantuckett.

By these grants to the Duke of York and the conquest of the Dutch possessions in America it will be seen that New York originally had a claim to a much larger territory than is now included in her limits. The successive changes in her extent may be sketched as follows, viz:

In 1664 the Duke of York sold the present State of New Jersey to Lord John Berkeley and Sir George Carteret.

In 1682 the Duke of York sold to William Penn his title to Delaware and the country on the west bank of the Delaware, which had been originally settled by the Swedes, then conquered by the Dutch, and which had by them been surrendered to the Duke of York.

In 1686 Pemaquid and its dependencies were annexed to the New England government by a royal order, the Duke of York having acceded to the throne of England.

By the charter of 1691 to Massachusetts Bay, all claim to any part of Maine was extinguished, and the islands of Nantucket, Marthas Vineyard, and others adjacent (hitherto known as Duke's County, New York), were annexed to Massachusetts Bay.

The territory west of the Connecticut River to within about 20 miles of the Hudson River, now forming a portion of Massachusetts and Connecticut, were, by agreements and concessions made at various periods, surrendered to those States respectively.

In 1781 New York released to the General Government all the lands to which she had claim west of a meridian extending through the west extremity of Lake Ontario, and in 1790 she gave up all claim to the present State of Vermont and consented to her independence.

By these successive reductions New York was left with substantially her present boundaries.

(For the history and settlement of the eastern boundary of New York, vide Vermont, Massachusetts, and Connecticut, ante, pp. 52, 68, and 73.) 


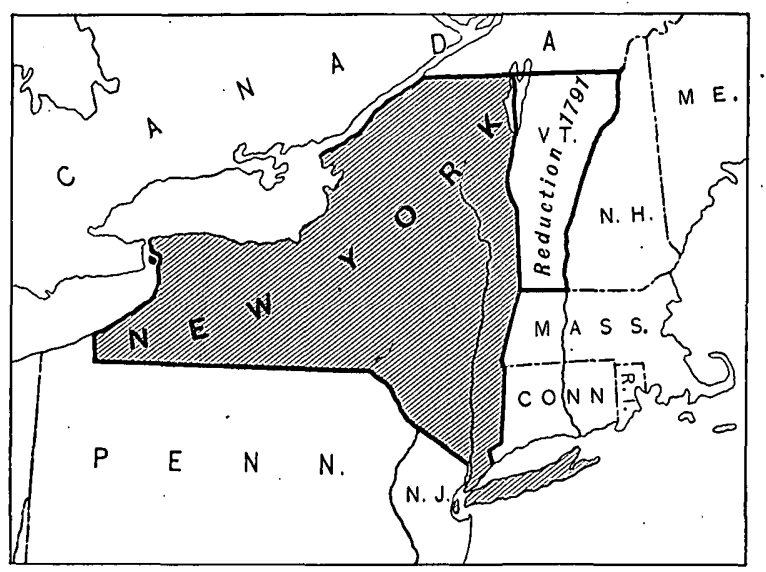

HISTORICAL DIAGRAM OF NEW YORK.

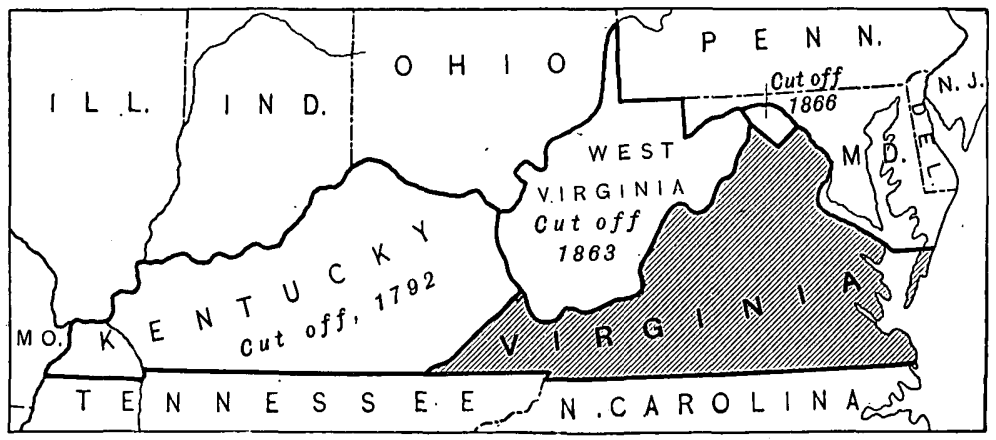

HISTORICAL DIAGRAM OF VIRGINIA. 
The northern boundary was settled by the treaty of peace in 1783 and by the commission under the sixth article of the treaty of Ghent. (Vide p. 11.)

The boundary between New York and New Jersey was plainly stated in the grant by the Duke of York to Berkeley and Carteret. (Vide New Jersey, p. 83.)

In 1719 attempts were made to have the line run and marked, but nothing seems to have been done to settle the matter permanently till 1769, when commissioners were appointed by the King, who fixed on substantially the present line. (Vide R. S. N. J., 1821, pp. 29-34.)

In 1772 this line was confirmed by the legislatures of both colonies, and commissioners were appointed to survey and mark the same.

This line was as follows, viz:

A direct and straight line from the fork or branch formed by the junction of the stream or waters called the Machackamack with the river Delaware or Fishkill, in the latitude of $41^{\circ} 21^{\prime} 37^{\prime \prime}$, to a rock on the west side of the Hudson River, marked by the said surveyors, in the latitude of $41^{\circ}$-said rock was ordered to be marked with the following words and figures, viz: "Latitude $41^{\circ}$ north;" and on the south side thereof, "New Jersey;" and on the north side thereof, "New York;" also to mark ;every tree that stood on the line with five notches and a blaze on the northwest and southeast:sides thereof, and to put up stone monuments, at 1 mile distance from each other, along the said line, and to number such monuments with the number of miles; the same shall be from the before-mentioned marked rock on the west side of Hudson's River, and mark the words "New Jersey". on the south side and the words "New York" on the north side of every of the said monuments. (See R. S. of N. J., 1821, pp. 29-34.)

The above was confirmed by the King in council September 1, 1773 .

In the year 1833 commissioners were appointed by New York and New Jersey for the settlement of the territorial limits and jurisdiction of the two States.

In the following year the commissioners made the following agreement, which was ratified by each State and confirmed by Congress, viz:

UNited STATES STATUTES A'T LARGE. TWENTY-THIRI) CONGRESS, SESSION I. 1834.

AN ACT giving the consent of Congress to an agreement or compact entered into between the State of New York and the State of New Jersey, respecting the territorial limits and jurisdiction of said States.

ArTicle first. The boundary line between the two States of New York and New Jersey, from a point in the middle of Hudson River, opposite the point on the west shore thereof, in the forty-first degree of north latitude, as heretofore ascertained and marked, to the main sea, shall be the middle of the said river, of the bay of New York, of the waters between Staten Island and New Jersey and of Raritan Bay, to the main sea, except as hereinafter otherwise particularly mentioned. ${ }^{\circ}$

Ar'ricLe SECOND. The State of New York shall retain its present jurisdiction of and over Bedloe's and Ellis's islands, and shall also retain exclusive jurisdiction of and over the other islands lying in the waters above mentioned and now under the jurisdiction of that State.

ARTICLE THIRD. The State of New York shall have and enjoy exclusive jurisdiction of and over all the waters of Hudson River lying west of Manhattan Island and to the 
south of the mouth of Spuytenduyvel Creek, and of and over the lands covered by the said waters to the low-water mark on the westerly or New Jersey side thereof, subject to the following rights of property and of jurisdiction of the State of New Jersey; that is to say:

1. The State of New Jersey shall have the exclusive right of property in and to the land under water lying west of the middle of the bar of New York and west of the middle of that part of the Hudson River which lies between Manhattan Island and New Jersey.

2. The State of New Jersey shall have the exclusive jurisdiction of and over the wharves, docks, and improvements made and to be made on the shore of the said State, and of and over all vessels aground on said shore, or fastened to any such wharf or dock, except that the said vessels shall be subject to the quarantine or health laws and laws in relation to passengers of the State of New York which now exist or which may hereafter be passed.

3. The State of New Jersey shall have the exclusive right of regulating the fisheries on the westerly side of the middle of said waters: Provided, That the navigation be not obstructed or hindered.

ARTICLE FOURTH. The State of New York shall have exclusive jurisdiction of and over the waters of the Kill Von Kull between Staten Island and New Jersey to the westernmost end off Shorter's Island in respect to such quarantine law's and laws relating to passengers as now exist or may hereafter be passed under the authority of that State, and for executing the same; and the said State shall also have exclusive jurisdiction for the like purposes of and over the waters of the Sound from the westernmost end of Shorter's Island to Woodbridge Creek as to all vessels bound to any port in the said State of New York.

ARTICLE FIFTh. The State of New Jersey shall have and enjoy exclusive jurisdiction of and over all the waters of the Sound between Staten Island and New Jersey lying south of Woodbridge Creek, and of and over all the waters of Raritan Bay lying westward of a line drawn from the light-house at Prince's Bay to the mouth of Mattavan Creek, subject to the following rights of property and of jurisdiction of the State of New York; that is to say:

1. The State of New York shall have the exclusive right of property in and to the land under water lying between the middle of the said waters and Staten Island.

2. The State of New York shall have the exclusive jurisdiction of and over the wharves, docks, and improvements made and to be made on the shore of Staten Island, and of and over all vessels aground on said shore or fastened to any such wharf or dock, except that the said vessels shall be subject to the quarantine or health laws and laws in relation to passengers of the State of New Jersey which now exist or which may hereafter be passed.

3. The State of New York shall have the exclusive right of regulating the fisheries between the shore of Staten Island and the middle of said waters: Provided, That the navigation of the said waters be not obstructed or hindered.

* $*$ * . * * * * * * * * *

In 1876 commissioners were appointed to relocate the land boundary between New York and New Jersey, and replace monuments that may have become dilapidated or removed, or to erect new ones, etc. (Vide Rev. of ${ }^{\prime}$ N. J., 1877.)

- The above commissioners found in some cases a slight discrepancy between the original marks and the verbal description thereof, and the legislatures of each State ordered that the original monuments should be considered the true boundary. (See acts of New York, 1880, and acts of New Jersey, 1881.) 


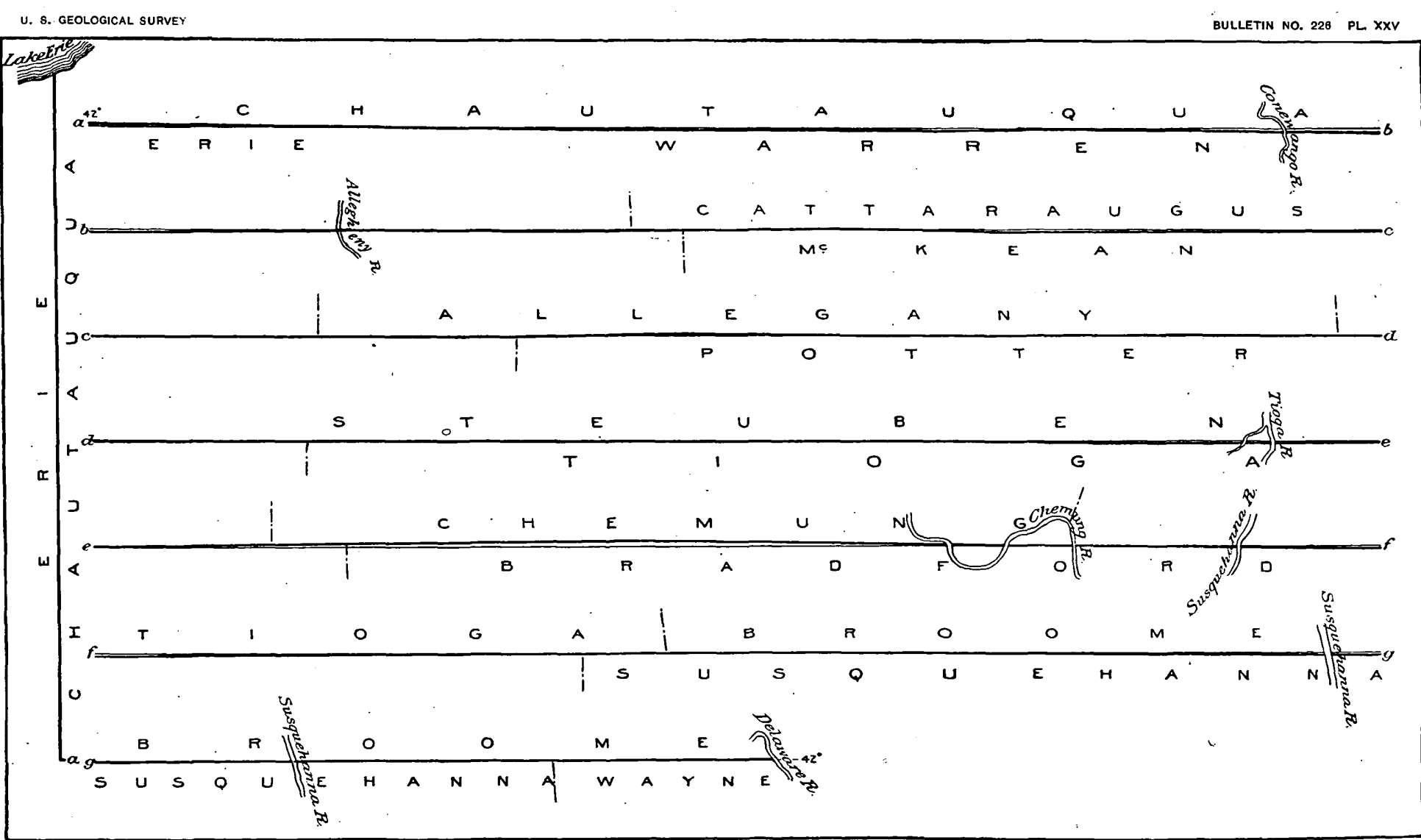


In 1881 a joint commission of the two States was appointed for the purpose of retracing and remarking, in a permanent manner, this boundary. This work was completed in a thorough manner in 1883.

In 1887 a joint commission of the two States was appointed to determine and mark the boundary between the two States through Raritan Bay. This commission came to an agreement, the terms of ,which are as follows:

First. From "Great Beds light-house," in Raritan Bay, north, twenty degrees sixteen minutes west, true, to a point in the middle of the waters of Arthur Kill, or Statèn Island Sound, equidistant between the southwesterly corner of the dwelling house of David C. Butler, at Ward's Point, on Staten Island, in the State of New York, at the southeasterly corner of the brick building on the lands of Cortlandt L. Parker, at the intersection of the westerly line of Water street with the northerly line of Lewis street, in Perth Amboy, in the State of New Jersey.

Second. From "Great Beds light-house," south, sixty-four degrees and twenty-one minutes east, true (S. $64^{\circ} 21^{\prime}$ E.), in line with the center of Waackaack or Wilson's beacon, in Monmouth County, New Jersey, to a point at the intersection of said line with a line connecting "Morgan No. 2" triangulation point, U. S. Coast and Geodetic Survey, in Middlesex County, New Jersey, with the "Granite and Iron beacon," marked on the accompanying maps as "Romer stone beacon," situated on the "Dry Romer shoal;" and thence on a line bearing north, seventy-seven degrees and nine minutes east, true (N. $77^{\circ} 9^{\prime}$ E.), connecting "Morgan No. 2" triangulation point, U. S. Coast and Geodetic Survey, in Middlesex County, New Jersey, with said "Romer stone beacon" (the line passing through said beacon and continuing in the same direction), to a point at its intersection with a line drawn between the "Hook beacon," on Sandy Hook, New Jersey, and the triangulation point of the U. S. Geodetic Survey, known as the Oriental Hotel, on Coney Island, New York; then southeasterly, at right angles with the last-mentioned line to the main sea.

Third. The monumental marks by which said boundary line shall be hereafter known and recognized are hereby declared to be as follows:

1. The "Great Beds light-house."

2. A permanent monument marked "State boundary line New York and New Jersey," and to be placed at the intersection of the line drawn from the "Great Beds light-house" to "Waackaack or Wilson's beacon," Monmouth County, New Jersey, and the line drawn from "Morgan No. 2" triangulation point, U. S. Coast and Geodetic Survey, in Middlesex County, New Jersey, to "Romer stone beacon."

3. Eight buoys or spindles; to be marked like the permanent monument above mentioned, and placed at suitable intervening points along the line from the said permanent monument tò the "Romer stone beacon."

4. The "Romer stone beacon."

In the year 1774 commissions were appointed by New York and Pennsylvania to fix the beginning of the forty-third degree of north latitude on the Mohawk or western branch of Delaware River, which is the northeast corner of Pennsylvania, and to proceed westward and fix the line between Pennsylvania and New York.

These commissioners reported in December of the same year that they fixed the said northeast corner of Pennsylvania, and marked it as follows, viz:

On a small island in the said river they planted a stone marked with the letters and figures, New York, 1774, cut on the north side thereof; and the letters and fig- 
ures, latitude $42^{\circ}$ variation $4^{\circ} 20^{\prime}$, cut on the top thereof; and in a direction due west from thence on the west side of the said branch of Delaware, collected and placed a heap of stones at the water mark; and proceeding further west four perches, planted another stone in the said line marked with the letters and figures, Pennsylvania, 1774 , cut on the south side thereof, and the letters and figures, latitude $42^{\circ}$ va 'iation $4^{\circ} 20^{\prime}$, cut on the top thereof, and at the distance of eighteen perches due west from the last-mentioned stone marked an ash tree. The rigor of the season prevented them running the line farther.

Nothing further seems to have been done until 1786-'7, when commissioners were appointed to finish the work thus begun (see Cary \& Riorden's Laws of Pennsylvania, Vol. III, page 392), and the lines were run and monuments erected. The line was ratified in 1789, and is as follows, viz:

Beginning at a point in Lake Erie, where the boundary line between the United States and Great Britain is intersected by a meridian line drawn through the most westerly bent or inclination of Lake Ontario; then south along said meridian line to a monument in the beginning of the forty-third degree of north latitude, erected in the year one thousand seven hundred and eighty-seven, by Abraham Herdenbergh and William W. Morris, commissioners on the part of this State, and Andrew Ellicott and Andrew Porter, commissioners on the part of the State of Pennsylvania, for the purpose of marking the termination of the line of jurisdiction between this State and the said State of Pennsylvania; then east along the line established and marked by said last-mentioned commissioners to the ninetieth milestone in the same parallel of latitude, erected in the year one thousand seven hundred and eighty-six, by James Clinton and Simeon DeWitt, commissioners on the part of this State, and Andrew Ellicott, commissioner on the part of Pennsylvania; which said ninetieth milestone stands on the western side of the south branch of the Tioga River; then east along the line established and marked by said last-mentioned commissioners, to a stone erected in the year one thousand seven.hundred and seventy-four, on a small island in the Delaware River, by Samuel Holland and David Rittenhouse, commissioners on the part of the colonies of Pennsylvania and New York, for the purpose of marking the beginning of the forty-third degree of North latitude; then down along said Delaware River to a point opposite to the fork or branch formed by the junction of of the stream called Mahackamack with the said Delaware River, in the latitude of forty-one degrees, twenty-one minutes and thirty.seven seconds north; then in a straight line to the termination on the east bank of the Delaware River of a line run in the year one thousand seven hundred and seventy-four, by William Wickham and Samuel Gale, commissioners on the part of the then colony of New York, and John Stevens and Walter Rutherford, commissioners on the part of the then colony of New Jersey. (See Revised Statutes of New York, 1881.)

The meridian line forming the western boundary of New York was surveyed and mapped in 1790 by Andrew Ellicott, as United States commissioner (Pa. Archives, Vol. XII-Map), and the latitude formerly inscribed on the monument on Lake Erie, fixing the western boundary, was $42^{\circ} 16^{\prime} 13^{\prime \prime}$. The report of the commissioner has not been found.

In 1865 Dr. Peters, director of Hamilton College Observatory, under the directions of the regents of the Eniversity of New York, determined the latitude and longitude of the boundary monument aforesaid, 
with the following result: Latitude, $42^{\circ} 16^{\prime} 2^{\prime \prime} .8$; longitude, $79^{\circ} 45^{\prime}$ 54".4. (Vide Dr. Peter's Report, 1868.)

In 1877 the parallel of the forty-second degree north latitude was ascertained at four points, by the New York and Pennsylvania Joint Boundary Commission, with the following result, viz:

1. At Travis Station (Hale's Eddy), very near the east end of that part of the New York and Pennsylvania line supposed to be on the forty-second parallel, the old line was found to be 275 feet north of the parallel.

2. At Finn's Station, about 20 miles from east end (Great Bend), the line is 350 feet south of the parallel.

3. At Burt's Station, about 70 miles from east end (Wellsburg), the line is 760 feet north of the parallel.

4. At Clark's Station, about 253 miles from east end (Wattsburg), the line is 150 feet north of the parallel.

(See pamphlet, Report of Penn. Board of the Penn. \& N. Y. Joint Boundary Comm.)

NEW JERSEY.

Although the original grants from the French and English sovereigns of 1603 and 1606 covered the territory forming the present State of New Jersey, the grant which first directly relates to New Jersey is that given in 1664 by the Duke of York to Lord John Berkeley and Sir George Carteret, two months before the setting out of his expedition to take possession of New York.

The following extract from that grant defines the boundaries, viz:

All that tract of land adjacent to New England, and lying and being to the westward of Long Island and Manbitas Island, and bounded on the east part by the main sea and part by Hudson River, and hath upon the west Delaware Bay or river, and extendeth southward to the main ocean as far as Cape May, at the mouth of Delaware Bay, and to the northward as far as the northernmost branch of the said bay or river of Delaware, which is forty-one degrees and forty minutes of latitude, and crosseth over thence in a straight line to Hudson River, in forty-one degrees of latitude; which said tract of land is hereafter to be called by the name or names of New Ceaserea or New Jersey. (Vide Grants, Concessions, etc., of New Jersey, Leaming \& Spicer, p. 8.)

In March, 1673, Lord Berkeley sold his undivided moiety of New Jersey to John Fenwick, by whom, in the following year, it was again sold. July 1, 1676, was executed the famous "Quintipartite deed," by which the eastern part was given to Sir George Carteret, to be called East New Jersey, and the western part to the other proprietors, to be called West New Jersey. Sir George Cartaret, at his death in 1678 , left his land to be sold. It was sold in 1682 to the twelve proprietors, who admitted other partners.

Confirmation grants were made to the proprietors of both provinces by the Duke of York, and confirmed by the King; but between 1697 Bull. 226-04-9 
and 1701 the proprietors repeatedly made petitions to be allowed to surrender their right of government to the Crown. Accordingly, in 1702, the surrender was made and accepted by the Queen, and both parts united were made the province of New Jersey. (Vide Leaming and Spicer's grants, etc.)

(For the history of the northern and eastern boundary, vide New York, p. 79.)

The grant from the Duke of York to Berkeley and Carteret defined the west boundary of New Jersey to be the Delaware River. (Vide p. 83.)

The line between New Jersey and Delaware is thus described in the Revised Statutes of Delaware, p. 2, viz:

Low-water mark on the eastern side of the river Delaware, within the twelve-mile circle from New Castle and the middle of the bay, below said circle.

In 1876 the legislature of New Jersey authorized the governor to commence a suit in the Supreme Court of the United States to settle the boundary between New Jersey and Delaware. New Jersey claimed jurisdiction to the middle of the Delaware, so far as the river and bay is a boundary between the two States. (Vide Revision of New Jersey, p. 1185.)

In 1783 Commissioner's were appointed by New Jersey and Pennsylvania to settle the jurisdiction of the river Delaware and the islands within the same. 'Their report was ratified, and is in substance as follows:

First. It is declared that the river Delaware from the station point or northwest corner of New Jersey, northerly to the place upon the said river where the circular boundary of the State of Delaware touches upon the same, in the whole length and breadth thereof, is and shall continue to be and remain a common highway, equally free and open for the use, benefit, and advantage of the said contracting parties, etc.

Second. That each State shall enjoy and exercise a concurrent jurisdiction within and upon the water, and not upon the dry land between the shores of said river, etc.

Third. That all islets, islands, and dry land within the bed and between the shores of said river, and between said station point northerly and the falls of Trenton southerly, shall, as to jurisdiction, be hereafter deemed and considered as parts and parcels of the State to which such insulated dry land doth lie nearest at the time of making this agreement, and that from said falls of Trenton to the State of Delaware southerly, certain islands (in the agreement they are named B) be annexed to each State respectively. (Vide Revision of New Jersey, p. 1181.)

In 1786 commissioners were appointed by New Jersey and Pennsylvania for more accurately determining and describing the islands mentioned in the foregoing agreement; that is, those in the Delaware from 
<smiles>C1CCCCCCCCCCCCC1</smiles> 
the northwest corner of New Jersey down to the falls of Trenton. Their report was ratified, and a long list of islands, described by name in the act, were annexed to each State respectively. (Tide Revision of New Jersey, pp. 1182-'3.)

\section{PENNSYLVANIA.}

The Swedish West India Company, chartered by the King of Sweden in 1625, established the first permanent settlement on the west bank of the Delaware, occupying a part of the territory now in Pennsylvania and Delaware, although the Dutch had previously established trading posts, which had been destroyed by the Indians. The Swedes acquired, by successive purchases from the Indian chiefs, all the land extending from Cape Henlopen to the great falls of the Delaware, calling it New Sweden. ( Vide C. and C., p. 1509.)

In 1655 this territory was surrendered to the Dutch. (Vide Hazard's Annals of Pennsylvania, p. 185.)

By the conquest of the New Netherlands, in 1664, the Duke of York seems to have successfully claimed the settlements on the west bank of the Delaware as part of his dominions.

In 1681 Charles II of England granted to William Penn the Province of Pennsylvania. The following extract from the charter defines the boundaries:

* * * all that Tracte or Parte of Land in America, with all the Islands therein conteyned, as the same is bounded on the East by Delaware River, from twelve miles distance Northwards of New Castle Towne unto the three and fortieth degree of Northerne Latitude, if the said River doeth extende so farre northwards; But if the said River shall not extend soe farre Northward, then by the said River soe farr as it doth extend; and from the head of the said River the Eastern Bounds are to bee determined by a Meridian Line, to bee drawne from the head of the said River, unto the said three and fortieth degree. The said Lands to extend westwards five degrees in longitude, to bee computed from the said Easterne Bounds; and the said Lands to bee bounded on the North by the beginning of the three and fortieth degree of Northern Latitude, and on the South by a Circle drawne at twelve miles distance from New Castle Northward and Westward unto the beginning of the fortieth degree of Northern Latitude, and thence by a streight Line Westward to the Limit of Longitude above mentioned.

William Penn, in order to perfect his title, procured of the Duke of York a deed bearing date August 21, 1682, by which the Duke of York conveyed to him all title and claim which he might have to the province of Pennsylvania. ( Vide Hazard's Annals of Pa., 586 et seq.)

He also purchased of the Duke of York the territory now comprising the State of Delaware, which he held until 1701-'2, when he granted a charter which enabled them to set up a separate government, though still under proprietary control. (Vide C. and C., p. 270 et seq.)

(For a history of the northern and eastern boundaries of Pennsylvania, see New York and New Jersey, pp. 81 and 84.) 
That part of the southern boundary of Pennsylvania between Pennsylvania and Delaware is an arc of a circle, having for its center the steeple of the old court-house at New Castle, Del., and a radius of 12 miles. This was surveyed and marked under a warrant from William Penn in 1701. (Vide Hazard's Annals of Pennsylvania.)

This circular line, in connection with adjacent lines, was made the subject of controversy for many years.

According to the original grants of Pennsylvania:and Maryland the boundary between them was to be the fortieth degree of north latitude.

This line being found to pass north of Philadelphia and to exclude Pennsylvania from Delaware Bay, negotiations ensued between the proprietors to rectify this geographical blunder, and for nearly a century the matter remained unsettled.

In the year 1732 an agreement was made to fix the boundary. Commissioners were appointed in that year, and subsequently in 1739 , to run the line, but they failed to agree, and chancery suits were the result. Taking a decision of Lord Chancellor Hardwick in 1750 as a basis of final adjudication, an agreement was signed July 4, 1760. By this agreement the line between Pennsylvania and Delaware on the one part and Maryland on the other was determined as follows, viz:

A due east and west line should be run across the peninsula from Cape Henlopen to the Chesapeake Bay. From the exact middle of this line should be drawn a line tangent to the western periphery of a circle, having a radius of 12 English statute miles, measured horizontally from the center of the town of New Castle. From the tangent point a line should be drawn due north until it cut a parallel of latitude 15 miles due south of the most southern part of the city of Philadelphia, this point of intersection to be the northeast corner of Maryland; thence the line should run due west on said parallel as far as it formed a boundary between the two governments. ( Vide Delaware, p. 87.)

In 1760 commissioners and surveyors were appointed, who spent three years in measuring the base line and the tangent line between Maryland and Delaware.

The proprietors then, wearied with the delay, sent over from England two famous mathematicians, Charles Dixon and Jeremiah Mason, who verified the work of their predecessors, and ran the line west between Pennsylvania and Maryland, since known as "Mason's and Dixon's line."

Mason and Dixon fixed the latitude of this line at $39^{\circ} 43^{\prime} 18^{\prime \prime}$. A resurvey in 1850 by Colonel Graham determined it to be $39^{\circ} 43^{\prime} 26^{\prime \prime} .3$.

Mason and Dixon begun their work in 1763 , and were stopped by Indians in 1767, having run the line about 244 miles west of the Delaware, not quite finishing their work. They put up mile stones all 
along said line, every fifth one being marked with the arms of the respective proprietors.

In consequence of the accidental removal of the stone at the northeast corner of Maryland, commissioners were apointed in 1850 by Pennsylvania, Delaware, and Maryland to revise the former survey, which was done by Lieutenant-Colonel Graham, of the United States topographical engineers. The result confirmed the work of Mason and Dixon, and Maryland gained by the resurvey a little less than two acres.

(For a full report of the running of Mason and Dixon's line in 1763-'67, and the verification by Colonel Graham in 1850, see Senate Journal of Delaware for 1851, pages .56-109.)

In 1784 the report of the commissioners who had been appointed to fix the boundaries between Virginia and Pennsylvania (West Virginia then forming part of Virginia) was confirmed, and the lines so fixed are as follows, viz:

The line commonly called Mason and Dixon's line to be extended due west five degrees of longitude from the river Delaware, for the southern boundary of Pennsylvania, and a meridian drawn from the western extremity thereof to the northern limits of the said states, respectively, be the western boundary of Pennsylvania. (Vide C. and B. laws of Pennsylvania, Vol. II, p. 495, and Hening's Virginia, Vol. XI, p. 554.)

By the cession of $17 \$ 4$, by Virginia to the United States-and that of 1800, by Connecticut to the United States, and the formation of the State of West Virginia from a portion of Virginia in 1862-the abovementioned meridian line' becomes the boundary between Pennsylvania on the east, and Ohio and West Virginia on the west.

By an examination of the cession of 1781, by New York to the United States, it will be seen that a small triangular tract on Lake Erie was left in the hands of the General Government. This was sold to Pennsylvania in 1792.

\section{DELAWARE.}

The State of Delaware was originally setteled by the Swedes. (Vide Pennsylvania, p. 85.) In 1655 it was surrendered to the Dutch, who, in 1664, in turn surrendered it to the English, and it was taken possession of by the Duke of York.

William Penn, having received in 1682 a grant of the province of Pennsylvania, bought of the Duke of York the territory comprising the present State of Delaware. It was conveyed to him by two deeds of feoffment, dated August 24, 1682, one conveying the town of New Castle and a twelve-mile circle around the same, and the other conveying all the lands south of said circle to Cape Henlopen. (See Hazard's Annals of Pennsylvania, p. 588 et seq.)

Soon after the grant made by the royal charter aforesaid, an assembly of the province and three lower counties (then called the terri- 
tories) was called by the proprietary and governor aforesaid, which met at Chester on the seventh day of December, 1682, when the following laws, among others, were passed, to wit:

* * * Since * * * ithas pleased King Charles the Second * * * togrant * * * William Penn., esq., **** this Province of Pennsylvania *** And * James Duke of York and Albany * * * to release his right and claim *. * * to the Province of Pennsylvania *** and *** to grant unto the said William Penn *** all that tract of land from twelve miles northward of New Castle, on the river Delaware, down to the South Cape (commonly called Cape Henlopen, and by the Proprietary and Governor now called Cape Jomus) lying on the west side of the said river and bay, $* *$ * lately cast into three counties, called New Castle, Jones, and Whorekills (alias New Dale. * * * Be it enacted * * that the counties of New Castle, Jones, and Whorekil]s alias New Dale *** are annexed to the Province of Pennsylvania. * * * (Dallas' Laws of Pennsylvania, 1797, Vol. I, Appendix, p. 24 et seq.)

In 1701 William Penn granted a charter, under which the province of Pennsylvania and the territories (as Delaware was then called) were made separate governments, though both were still under the proprietary government of William Penn. (C. \& C., p. 270.)

By the Revolution the "territories" became the State of Delaware, with substantially her present boundaries:

(For a history of the boundaries between Delaware and Pennsylvania, vide Pennsylvania, p. 85, and between Delaware and New Jersey, vide New Jersey, p. 83 et seq.)

From 1732 to 1769 there was a controversy between the proprietors of Pennsylvania and Maryland in regard to boundaries (vide p. 86). The boundaries of Delaware on the north and west-Delaware then being under the jurisdiction of Pennsylvania-were determined as follows, viz:

Beginning at Cape Henlopen and running due west 34 miles 309 perches; thence in a straight line 81 miles 78 chains and 30 links up the peninsula until it touches and makes a tangent to the western periphery of a circle, drawn at the horiztonal distance of twelve English statute miles from the center of the town of New Castle.

From this tangent point a line was run due north till it cut a parallel of latitude 15 miles due south of the most southern part of the city of Philadelphia. This point of intersection is the northeast corner of Maryland. The tangent line bearing a little west of north, the due north line from the tangent point cuts off an arc of the 12-mile circle. The boundary line follows the arc of the circle from the tangent point around to the point where the due north line intersects the 12-mile circle, then follows said due north line to said northeast corner of Maryland. The length of said due north line is 5 miles 1 chain and 50 links, as given by Mason and Dixon. (Vide Jour. Del. Sen., 1851, p. 56 et seq.)

By the agreement of 1760 , based on the decree of Chancellor Hard- 
wick, a due east and west line should be run across the peninsula from Cape Henlopen to Chesapeake Bay, etc. The decree of Lord Hardwick says, touching the position of Cape Henlopen, "that Cape Henlopen ought to be deemed and taken to be situated at the place where the same is laid down and described in the map or plan annexed to the said articles to be situated, and therefore his lordship doth further order and decree that the said articles be carried into execution accordingly," etc.

In Hazard's Annals of Pennsylvania, p. 5 , is found the following, viz: "The cape now called Henlopen was then called Cornelis."

William Penn directed that Cape Henlopen be called Cape James. (Vide Hazard's Pennsylvania, p. 606; also vide act of union of the territories to Pennsylvania.)

The foregoing statements explain the seeming incongruity between the base line across the peninsula and the position of Cape Henlopen as laid down on all modern maps.

\section{MARYLAND.}

The territory comprising the present area of Maryland was included in the previous charters of Virginia, notwithstanding which, in the year 1632, Lord Baltimore received a royal grant of the province of Maryland, whose boundaries are defined in the following extract:

All that part of the Peninsula or Chersonese, lying in parts of America, between the ocean on the east and the Bay of Chesapeake on the west; divided from the residue thereof by a right line drawn from the promontory or headland called Watkins Point, situate upon the bay aforesaid, near the River Wighco on the west unto the main ocean on the east, and between that boundary on the south unto that part of the Bay of Delaware on the north, which lieth under the fortieth degree of north latitude from the equinoctial, where New England is terminated; and all the tract of that land within the metes underwritten (that is to say), passing from the said bay, called: Delaware Bay, in a right line, by the degree aforesaid, unto the true meridian of the first fountain of the River Pattowmack; thence verging towards the south unto the farther bank of the said river, and following the same on the west and south unto a certain place called Cinquack, situate near the mouth of said river, where it disembogues into the aforesaid Bay of Chesapeake, and thence by the shortest line unto the aforesaid promontory or place called Watkins Point, so that the whole tract of land divided by the line aforesaid, between the main ocean and Watkins Point unto the promontory called Cape Charles, may entirely remain forever excepted to us *******.

By an examination of the limits laid down in this charter, and a comparison with the several charters of Virginia and the charter and deeds to William Penn, it will be seen that there was a conflict of boundaries on both sides of the Maryland grant.

The history of the long controversy with Pennsylvania has already been given (vide Pennsylvania, p. 85', and Delaware, p. 87). Virginia on the south claimed the territory under her charters, and for a time seemed disposed to assert her claim, notwithstanding we find in 1638 a 
proclamation by the governor and council of Virginia recognizing the province of Maryland, and forbidding trade with the Indians within the limits of Maryland without the consent of Lord Baltimore previo usly obtained (vide Bozman's Maryland, Vol. II, p. 586). Virginia's claim was finally given up by a treaty or agreement made in 1658. (For a full account vide Bozman's Maryland, p. 444 et seq.)

In 1663 the Virginia assembly ordered a survey of the line between Virginia and Maryland on the peninsula, and declared it to be as follows, viz:

From Watkins Point east across the peninsula.

They define Watkins Point

To be the north side of Wicomicoe River on the eastern shore and neere unto and on the south side of the streight limbe opposite to Patuxent River.

(Vide Hening's Virginia, Vol. II, p. 184.)

In 1668 commissioners were appointed by Maryland and Virginia to fix the boundary across the peninsula. The commissioners were Philip Calvert, esq., chancellor of Maryland, and Col. Edmund Scarbrugh, his majesty's surveyor-general of Virginia. Their report is as follows, viz:

* * * After a full and perfect view taken of the point of land made by the north side of Pocomoke Bay and south side of Annamessexs Bay have and do conclude the same to be Watkins Point, from which said point so called, we have run an east line, agreeable with the extreamest part of the westermost angle of the said Watkins Point, over Pocomoke River to the land near Robert Holston's, and there have marked certain trees which are so continued by an east line running over Swansecutes Creeke into the marsh of the seaside with apparent marks and boundaries * * * Signed June 25, 1868. (Vide Md. Hist. Soc. Coll. of State papers, volume marked 4 L. C. B., pp. 63-64.)

Virginia, by the adoption of her constitution of 1776 (see Article 21), relinquished all claim to territory covered by the charter of Maryland, thereby fixing Maryland's western boundary as follows:

Commencing on a true meridian of the first fountain of the river Pattawmack, thence verging towards the south unto the further bank of the said riverand following the same on the west and south unto a certain place called Cinquack, situate near the mouth of said river where it disembogues into the aforesaid bay of Chesapeake, and thence by the shortest line unto the aforesaid promontory or place called Watkins Point; thence a right line to the main ocean on the east. (See charter of Maryland.)

The foreging are substantially the present boundaries; but from that time up to the present a controversy has been going on concerning them.

In 1786 a compact was entered into between the States of Maryland and Virginia, but as this referred more particularly to the navigation and exercise of jurisdiction on the waters of Chesapeake Bay, the Potomac and Pocomoke rivers, they are not given here. (Vide Hening's Va., Vol. XII, p. 50.) 
From 1821 to 1858 frequent legislation took place in regard to this boundary.

In the last-named year commissioners were appointed by Maryland and Virginia, respectively, who, with the assistance of Lieut. N. Michler, United States Engineers, surveyed the lines.

In 1860 the governor of Virginia, under a resolution of the legislature, appointed and sent an agent to England to collect records and documentary evidence bearing on this question.

The rebellion ensuing, nothing further was done until 1867, when legislation again commenced.

The question of this boundary was referred to arbitrators by an agreement made in 1874, each State binding itself to accept their award as final and conclusive.

J. S. Black, of Pennsylvania; William A. Graham, of North Carolina, and Charles A. Jenkins, of Georgia, were appointed arbitrators.

William A. Graham having died, James B. Beck, of Kentucky, was appointed in his stead.

The arbitrators made, in 1877, the following award, viz:

Beginning at the point on the Potomac River where the line between Virginia and West Virginia strikes the said river at low-water mark, and thence following the meanderings of said river by the low-water mark to Smith's Point, at or near the mouth of the Potomac, in the latitude $37^{\circ} 53^{\prime} 8^{\prime \prime}$ and longitude $76^{\circ} 13^{\prime} 46^{\prime \prime}$; thence crossing the waters of the Chesapeake Bay, by a line running north $65^{\circ} 30^{\prime}$ east, about nine and a half nautical miles to a point on the western shore of Smith's Island at the north end of Sassafras Hammock, in latitude $37^{\circ} 57^{\prime} 13^{\prime \prime}$, longitude $76^{\circ} 2^{\prime} 52^{\prime \prime}$; thence across Smith's Island south $88^{\circ} 30^{\prime}$ east five thousand six hundred and twenty yards to the center of Horse Hammock, on the eastern shore of Smith's Island, in latitude $37^{\circ} 57^{\prime} 8^{\prime \prime}$, longitude $75^{\circ} 59^{\prime} 20^{\prime \prime}$; thence south $79^{\circ} 30^{\prime}$ east four thousand eight hundred and eighty yards to a point marked " $A$ " on the accompanying map, in the middle of Tangier Sound, in latitude $37^{\circ} 56^{\prime} 42^{\prime \prime}$, longitude $75^{\circ} 56^{\prime} 23^{\prime \prime}$, said point bearing from James Island light south $54^{\circ}$ west, and distant from that light three thousand five hundred and sixty yards; thence south $10^{\circ} 30^{\prime}$ west four thousand seven hundred and forty yards by a line dividing the waters of Tangier Sound, to a point where it intersects the straight line from Smith's Point to Watkins Point, said point of intersection being in latitude $37^{\circ} 54^{\prime} 21^{\prime \prime}$, longitude $75^{\circ} 56^{\prime} 55^{\prime \prime}$, bearing from James Island light south $29^{\circ}$ west and from Horse Hammock south $34^{\circ} 30^{\prime}$ east. This point of intersection is marked " $\mathrm{B}$ " on the accompanying map. Thence north $85^{\circ} 15^{\prime}$ east six thousand seven hundred and twenty yards along the line above mentioned, which runs from Smith's Point to Watkins Point until it reaches the latter spot, namely, Watkins Point, which is in latitude $37^{\circ} 54^{\prime} 38^{\prime \prime}$, longitude $75^{\circ} 52^{\prime} 44^{\prime \prime}$. From Watkins Point the boundary line runs due east seven thousand eight hundred and eighty yards to a point where it meets a line running through the middle of Pocomoke Sound, which is marked " $\mathrm{C}$ " on the accompanying map, and is in latitude $37^{\circ} 54^{\prime} 38^{\prime \prime}$, longitude $75^{\circ} 47^{\prime} 50^{\prime \prime}$; thence by a line dividing the waters of Pocomoke Sound north $47^{\circ} 30^{\prime}$ east five thousand two hundred and twenty yards to a point in said sound marked " $\mathrm{D}$ " on the accompanying map, in latitude $37^{\circ} 56^{\prime} 25^{\prime}$, longitude $75^{\circ} 45^{\prime} 26^{\prime \prime}$; thence following the middle of Pocomoke River by a line of irregular curves, as laid down on the accompanying map, until it intersects the westward protraction of the boundary line marked by Scarborough and Calvert, May 28, 1668; at a point in the middle of Pocomoke River, and in the latitude $37^{\circ} 59^{\prime} 37^{\prime \prime}$, 
longitude $75^{\circ} 37^{\prime} 4^{\prime \prime}$; thence by the Scarborough and Calvert line, which runs $5^{\circ} 15^{\prime}$ north of east, to the Atlantic Ocean.

The latitudes, longitudes, courses, and distances here given have been measured upon the Coast Chart No. 33 of U. S. Coast Survey, sheet No. 3, Chesapeake Bay. * * * The middle thread of the Pocomoke River and the low-water mark on the Potomac River are to be measured from headland to headland, without considering or following arms, inlets, creeks, bays, or affluent rivers. *** (Vide, U. S. Stat. at Large, Vol. XX, p. 481.)

This award was ratified by the States of Maryland and Virginia, and confirmed by Congress in 1879 .

In 1879-80 acts were passed by the legislatures of Maryland and Virginia to appoint commissioners and to request the General Government to designate one or more officers of the Engineer Corps, said commissioners and officers to survey and mark said line and erect monuments thereon.

West Virginia having been formed from a part of Virginia and admitted into the Union in 1862, the western boundary of Maryland now separates it from the State of West Virginia.

The commissioners appointed in 1859 by Virginia and Maryland (vide p. 91) surveyed the western boundary from the "Fairfax Stone" (the first fountain of the Potomac) due north to the Pennsylvania line, and the legislature of Maryland in 1860 passed an act declaring that line to be its western boundary.

From the "Fairfax Stone" the boundary between Maryland and West Virginia runs along the south bank of the Potomac River till it strikes the line between Virginia and West Virginia.

(For a history of the placing of the Fairfax Stone, vide Virginia, p. 96.)

\section{DISTRICT OF COLUMBIA.}

On the 5th day of September, 1774, the Continental Congress met at Philadelphia. Two year's later they adjourned to Baltimore. During the Revolution and subsequent to the treaty of peace they met in various places. After the close of the war much debate took place in regard to the location of a permanent seat of the Government of the United States. Several States made propositions to Congress, offering to cede certain lands for the purpose, but no determination of the location was made by Congress until 1790.

Act of cession from the State of. Maryland, passed December \$3, 1788.

On the 23d of December, 1788, the State of Maryland passed the following act, viz:

$B e$ it enacted by the general assembly of Maryland, That the representatives of this State in the House of Representatives of the Congress of the United States, appointed to assemble at New York on the first Wednesday of March next, be, and they are hereby, authorized and required on the behalf of this State to cede to the Congress of the United States any district in this State, not exceeding ten miles square, which the Congress may fix upon and accept for the seat of government of the United States. 
In the following year (December 3, 1789), the State of Virginia passed a similar act, of which the following is an extract:

Be it therefore encuted by the general assembly, That a tract of country not exceeding ten miles square or any lesser quantity, to be located within the limits of the State and in any part thereof as Congress may by law direct, shall be, and the same is hereby, forever ceded and relinquished to the Congress and Government of the United States, in full and absolute right and exclusive jurisdiction, as well of said soil as of persons residing or to reside thereon, pursuant to the tenor and effect of the eighth section of the 1st article of the Constitution of the Government of the United States.

After long discussion, Congress in 1790 , in view of the foregoing cessions of Maryland and Virginia, passed the following act, viz:

AN ACr for establishing the temporary and permanent seat of government of the United States Approved July 16, 1790.

Secr. 1. Be it enacted by the Senate and House of Representatives of the United States of America in Congress assembled, That a district of territory, not exceeding ten miles square, to be located as hereafter directed on the river Potowmac, at some place between the mouth of the Eastern Branch and Connoyocheque, be, and the same is hereby, accepted for the permanent seat of the government of the United States: Provided, nevertheless, That the operation of the laws of the State within such district shall not be affected-by this acceptance until the time fixed for the removal of the Government thereto, and until Congress shall otherwise by law provide.

Secr. 2. And be it further enacted, That the President of the United States be authorized to appoint, andi, by supplying vacancies happening from refusals to act or other causes, to keep in appointment as long as may be necessary, three commissioners, who, or any two of whom, shall, under the direction of the President, survey, and by proper metes and bounds define and limit, a district of territory, under the limitations above mentioned; and the district so defined, limited, and located shall be deemed the district accepted by this act for the permanent seat of the Government of the United States.

SeC1. 3. And be it enacted, That the said commissioners, or any two of them, shall have power to purchase or accept such quantity of land on the eastern side of the said river within the said district as the President shall deem proper for the use of the United States, and according to such plans as the President shall approve. The said commissioners, or any two of them, shall, prior to the first Monday in December in the year 1800, provide suitable buildings for the accommodatiou of Congress, and of the President, and for the public offices of the Government of the United States.

Secr. 4. And be it enacted, That for defraying the expenses of such purchases and buildings the President of the United States be authorized and requested to accept grants of money.

Secr. 5. And be it enacted, That prior to the first Monday in December next all offices attached to the seat of government of the United States shall be removed to, and until the first Monday in December in the year 1800 shall remain at, the city of Philadelphia, in the State of Pennsylvania, at which place the session of Congress next ensuing the present shall be held.

Sест. 6. And be it enacted, That on the first Monday in December, in the year 1800, the seat of the Government of the United States shall, by virtue of this act, be transferred to the district and place aforesaid. And all offices attached to the said seat of government shall accordingly be removed thereto by their respective holders and shall, after the said day, cease to be exercised elsewhere, and that the necessary expense of said removal shall be defrayed out of the duties on imposts and tonnage, of which a sufficient sum is hereby appropriated. 
In the following year the foregoing act was amended, in order to include a portion of the Anacostia River ("Eastern Branch"), and the town of Alexandria within the limits of the district.

The following is the act of amendment:

AN ACT to amend "An act for establishing the temporary and permanent seat of government of the United States." Approved March 3, 1791.

Be it enacted, \&c., That so much of the act entitled "An act for establishing the temporary and permanent seat of the Government of the United States" as requires that the whole of the district of territory, not exceeding ten miles square, to be located on the river Potowmac for the permanent seat of the Government of the United States shall be located above the mouth of the Eastern Branch be, and is hereby, repealed, and that it shall be lawful for the President to make any part of the territory below said limit and above the mouth of Hunting Creek a part of the said district, so as to include a convenient port of the Eastern Branch and of the lands lying on the lower side thereof, and also the town of Alexandria; and the territory so to be included shall form a part of the district not exceeding ten miles square for the permanent seat of the Government of the United States, in like manner and to all intents and purposes as if the same had been within the the purview of the above recited act: Provided, That nothing herein contained shall authorize the erection of the public buildings otherwise than on the Maryland side of the river Potowmac, as required by the aforesaid act.

In pursuance of the foregoing acts, three commissioners were appointed, who made preliminary surveys of the territory, and on the 30th day of March, 1791, George Washington, President of the United States, issued a proclamation, in which the bounds of the said District were defined as follows, viz:

Beginning at Jones' Point, being the upper cape of Hunting Creek, in Virginia, and at an angle in the outset of $45^{\circ}$ west of the north, and running in a direct line ten miles for the first line; then beginning again at the same Jones' Point and running another direct line at a right angle with the first, across the Potomac, ten miles for the second line; then, from the terminations of the said first and second lines, running two other direct lines, of ten miles each, the one crossing the Potomac and the other the Eastern Branch aforesaid, and meeting each other in a point.

In 1800 Congress removed to this District. In the following year the District was divided into two counties, as follows, viz:

UNITED STATES STATUTES AT LARGE, StXTH CONGRESS, SECOND SESSION, 1801, (CHAPTER XV).

AN ACT concerning the District of Columbia.

The said District of Columbia shall be formed into two counties. One county shall contain all that part of said district which lies on the east side of the river Potomac, together with the islands therein, and shall be called the county of Washington, the other county shall contain all that part of said District which lies on the west side of said river, and shall be called the county of Alexandria; and the said river, in its whole course through said District, shall be taken and deemed to all intents and purposes to be within both of said counties.

In 1846 Congress passed an act retroceding to the State of Virginia that part of the District of Columbia originally ceded to the United 


$$
\text { Sub }
$$




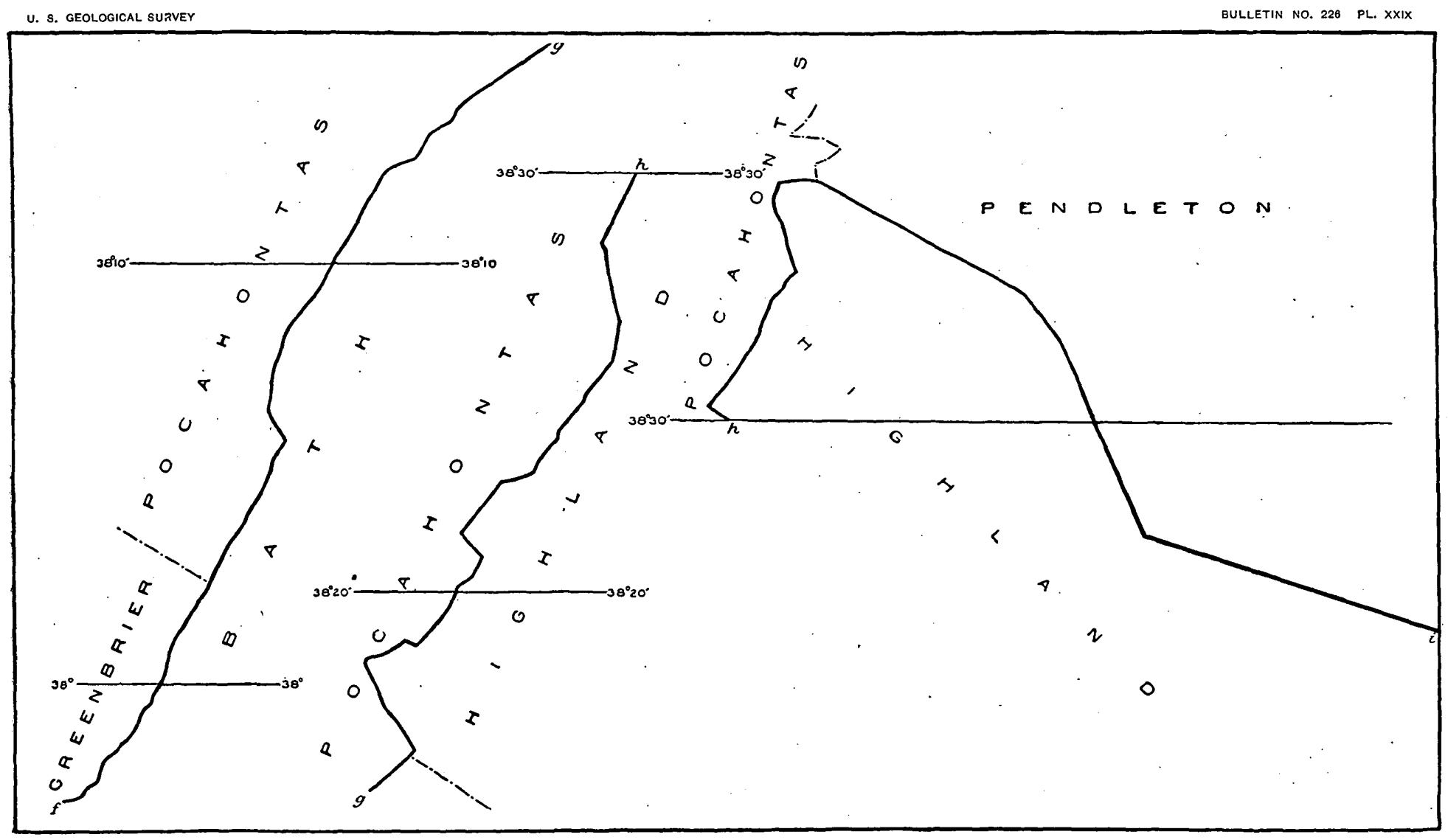

BOUNDARY BETWEEN VIRGINIA AND WEST VIRGINIA. 


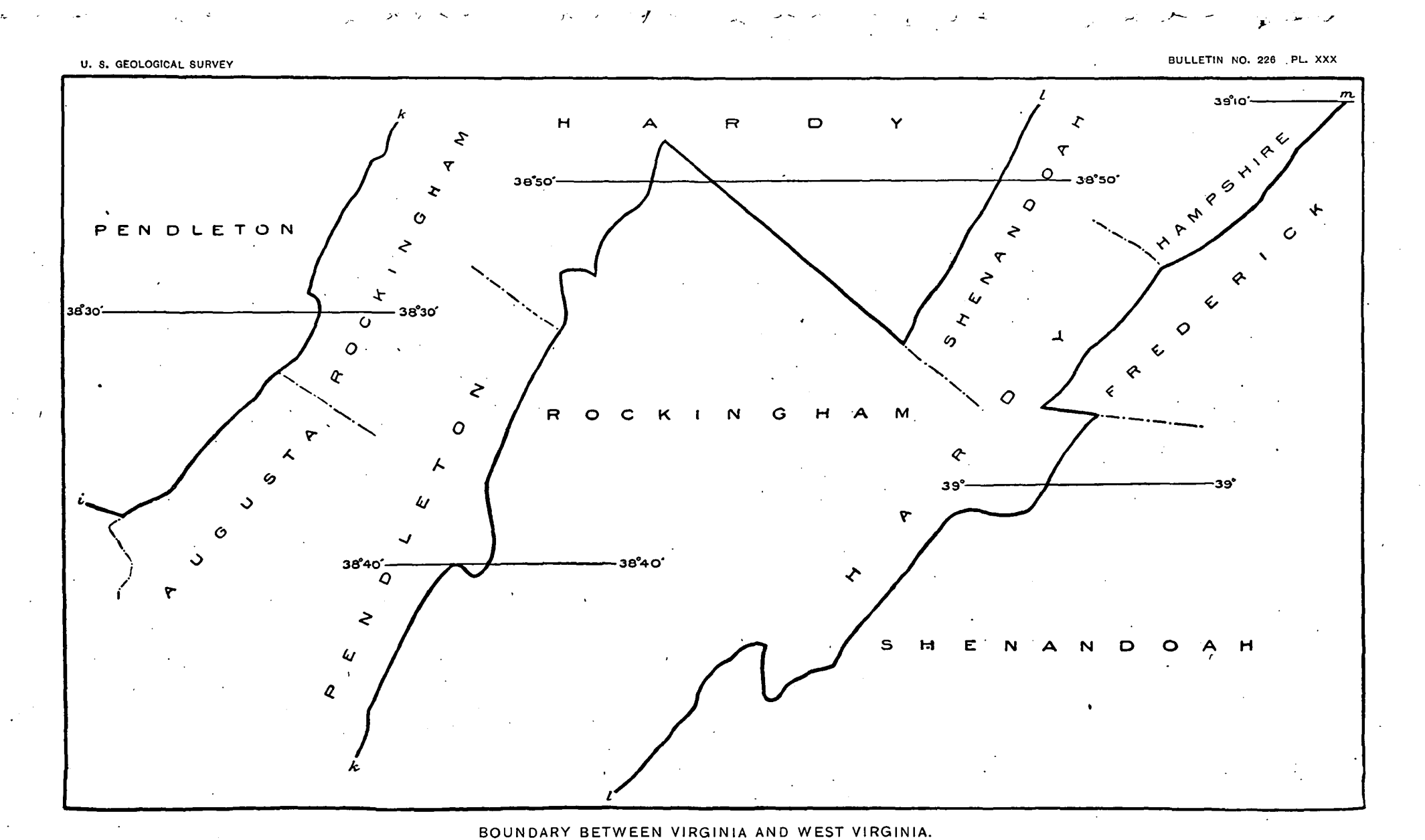


<smiles>C=CCC(C)CCCCCCCCCCCC</smiles> 
States by Virginia. The following is an extract from said act of retrocession:

That with assent of the people of the county and town of Alexandria, to be ascertained as hereinafter prescribed, all of that portion of the District of Columbia ceded to the United States by the State of Virginia, and all the rights and jurisdiction therewith ceded over the same, be, and the same are, hereby ceded and forever relinquished to the State of Virginia in full and absolute right and jurisdiction, as well of soil as of persons residing or to reside thereon.

\section{VIRGINIA.}

In the year 1606 King James I of England granted the "First Charter of Virginia." The boundaries therein described are as follows, viz:

* * *. Situate, lying, or being all along the sea consts, between four and thirty degrees of northerly latitude from the equinoctial line and five and forty degrees of the same latitude, and in the main land between the same four and thirty and five and forty degrees and the islands thereunto adjacent, or within one hundred miles of the coast thereof.

Soon after, in 1609 , a new charter was granted, called the "Second Charter of Virginia," which defines the boundaries in the following terms:

* * * Situate, lying, and being in that part of America called Virginia, from the point of land called Cape or Point Comfort, all along the sea coast to the northward two hundred miles, and from the said point of Cape Comfort all along the sea coast to the southward two hundred miles, and all that space and circuit of land lying from the sea coast of the precinct aforesaid up into the land, throughout from sea to sea, west and northwest, and also all the islands lying within one hundred miles along the coast of both seas of the precinct aforesaid.

In 1611-'12 the "Third Charter of Virginia" was granted, which was an enlargement of the second, of which the following is an extract:

All and singular those islands whatsoever, situate and being in any part of the ocean seas bordering upon the coast of our said first.colony in Virginia, and being within three hundred leagues of any of the portes heretofore granted to the said treasurer and company in our former letters-patents as aforesaid, and being within or between the one-and-fortieth and thirtieth degrees of northerly latitude.

These boundaries, as will be seen, included territory composing wholly, or in part, the present States of Pennsylvania, Delaware, Maryland, North and South Carolina, in addition to others formed since the Revolution.

This large extent of territory was reduced in the first instance by the charter of Maryland in 1632, next by the charters of Carolina in 1663 and 1665, then by the charter of Pennsylvania in 1681, and, again, subsequent to the Revolution, by the cession to the United States of the territory northwest of the Ohio River in 1784, by the admission of Kentucky as an independent State in 1792, and lastly by the division of the territory of Virginia in 1862, by which the new State of West Virginia was created and admitted into the Union. 
By the constitution of 1776 Virginia formally gave up all claim to the territory now appertaining to the neighboring States of Maryland, Pennsylvania, North and South Carolina.

The following is an extract from the Virginia constitution of 1776 :

The territories contained within the charters erecting the colonies of Maryland, Pennsylvania, North and South Carolina are hereby ceded, released, and forever confirmed to the people of these colonies, respectively, with all the rights of property, jurisdiction, and government, and all the rights whatsoever which might at any time heretofore have been claimed by Virginia, except the free navigation and use of the Rivers Potomaque and Pokomoke, with the property of the Virginia shores and strands bordering on either of said rivers, and all improvements which have been or shall be made thereon. The western and northern extent of Virginia shall, in all other respects, stand as fixed by the charter of King James I, in the year one thousand six hundred and nine, and by the public treaty of peace between the courts of Britain and France in the year one thousand seven hundred and sixty-three, unless by act of the legislature one or more governments be established westwards of the Alleghany Mountains.

In the mean time a grant of territory had been made within the present limits of Virginia and West Virginia, which caused great dissatisfaction to the people of the Virginia Colony, and which ultimately had an important bearing in settling the divisional line between Maryland and Virginia.

- In the 21st year of Charles II a grant was made to Lord Hapton and others of what is called the northern neck of Virginia, which was sold by the other patentees to Lord Culpeper and confirmed to him by letters-patent in the fourth year of James II. This grant carried with it nothing but the right of soil and incidents of ownership, it being expressly subjected to the jurisdiction of the government of Virginia. The tract of land thereby granted was "bounded by and within the heads of the rivers Tappahannock, alias Rappahannock, and Quiriough, alias Patomac, rivers." On the death of Lord Culpeper this proprietary tract descended to Lord Fairfax, who had married Lord Culpeper's only daughter.

As early as 1729 difficulties sprung up, arising from conflicting grants from Lord Fairfax and the Crown.

In 1730 Virginia petitioned the King, reciting that the head springs of the Rappahannock and Potomac Rivers were not known, and praying that such measures might be taken that they might be ascertained to the satisfaction of all parties.

In 1733 Lord Fairfax made a similar petition, asking that a commission might issue for running out, marking, and ascertaining the true boundaries of his grant.

An order, accordingly, was issued and three commissioners were appointed on the part of the Crown and three on the part of Lord Fairfax.

The duty which devolved upon these commissioners was to ascertain 


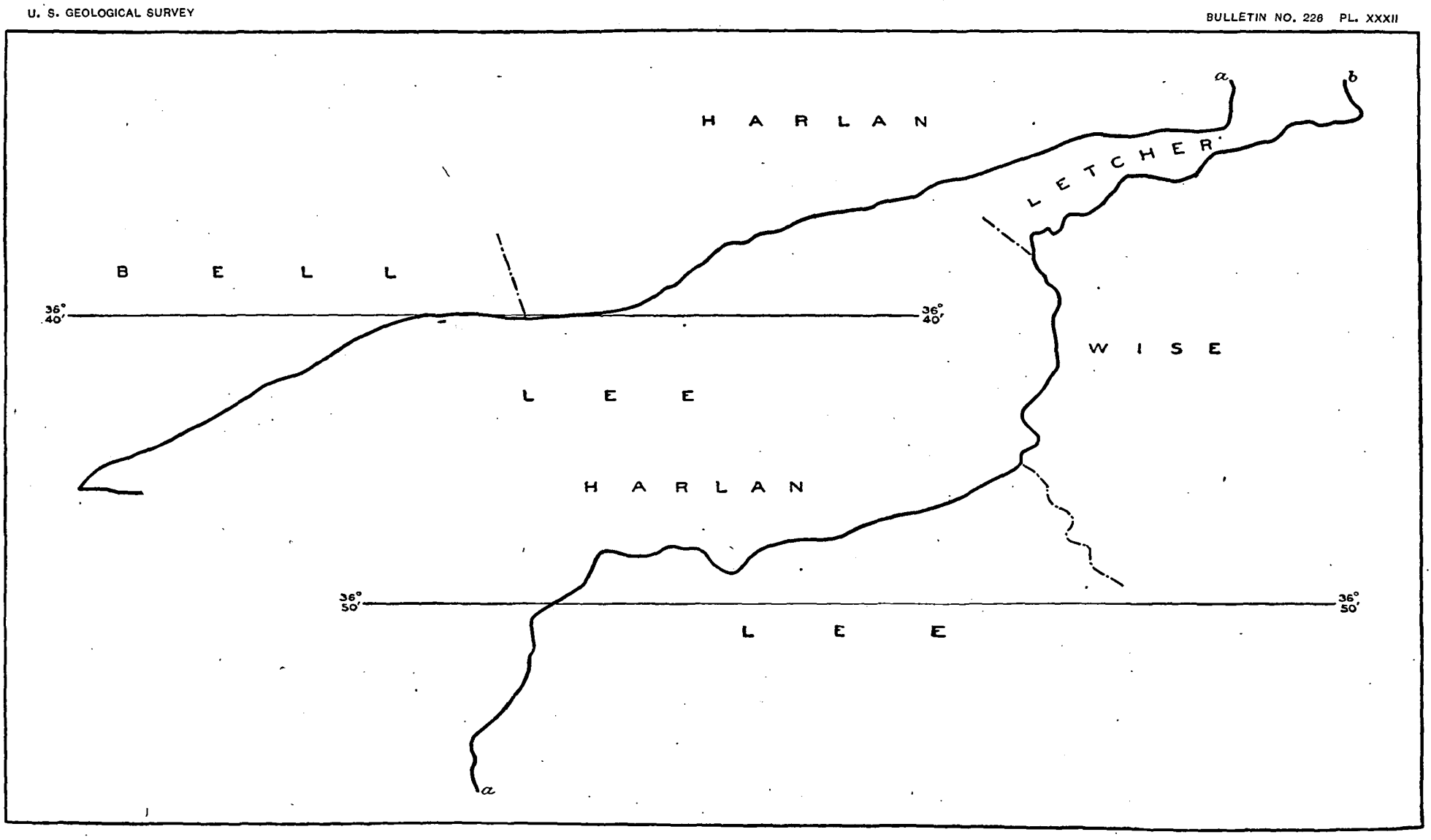

BOUNDARY BETWEEN VIRGINIA AND KENTUCKY. 
U. S. GEOLOGICAL SURVEY

BULLETIN NO. 228 PL. XXXIII

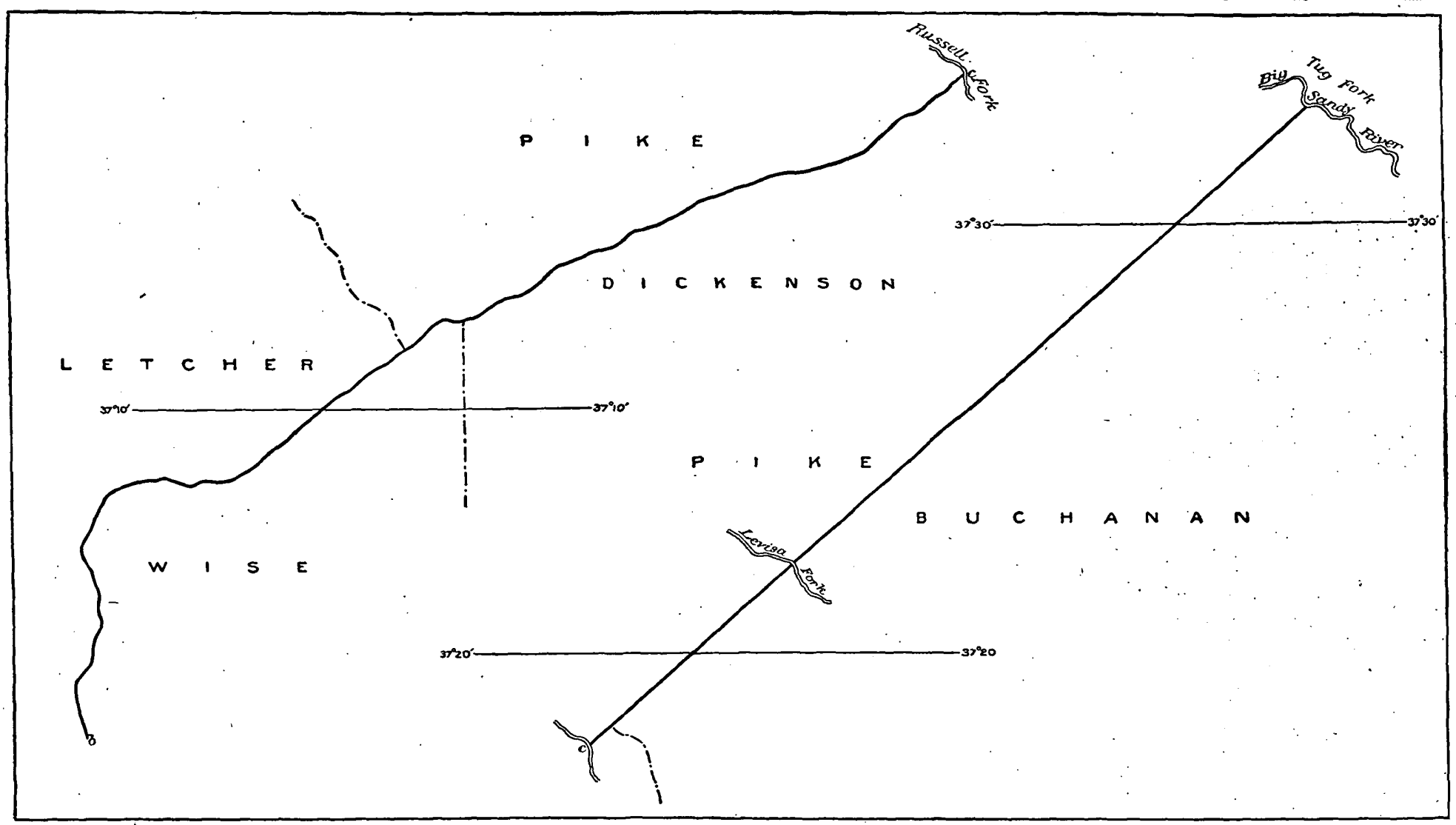

BOUNDARY BETWEEN VIRGINIA AND KENTUCKY. 
by actual examination and survey the respective fountains of the Rappahannock and Potomac rivers. This survey was made in 1736.

The report of the commissioners was referred to the council for plantation affairs in 1738 , who reported their decision in 1745 , as follows, viz:

* * * The said boundary ought to begin at the first spring of the south branch of the river Rappahannock, and that the said boundary be from thence drawn in a straight line northwest to the place in the Alleghany Mountains where that part of the Potomac River, which is now called Cohongoroota, first rises.

This report was confirmed by the King, and commissioners were appointed to run and mark the dividing line accordingly.

The line was run in 1746 . On the 17th day of October, 1746, they planted the Fairfax stone at the spot which had been described and marked by the preceding commissioners as the true head spring of the Potomac River, and which, notwithstanding much controversy, has continued to be regarded, from that period to the present time, as the southern point of the western boundary between Virginia and Maryland. (Vide Faulkner's Report to Governor of Virginia, 1832. For full details, vide Byrd Papers, 1866, Vol. II, p. 83 et seq. Also Hening's Va. Statutes.)

This tract of country was held by Lord Fairfax and his descendants many years, but subsequent to the Revolution the quitrents, charges, etc., were abolished, and it became in all respects subject to the jurisdiction of Virginia.

(For the history of the settlement of the boundary lines between Virginia and Maryland, vide Maryland, p. 89.)

(For a history of the boundary between Virginia and Pennsylvania, vide Pennsylvania, p.. 85.)

Kentucky formed originally a part of the county of Fincastle, Virginia. In the year 1776 this county was divided into three counties, the westernmost of which was called Kentucky County, and its eastern boundary was declared to be as follows, viz:

A line beginning on the Ohio, at the mouth of Great Sandy Creek, and running up the same and the main or northeasterly branch, thereof to the Great Laurel Ridge or Cumberland Mountains; thence southwesterly along the said mountain to the line of North Carolina. (See Hening's Statutes, Virginia, vol. 9, p. 257.)

Kentucky having been admitted into the Union June 1, 1792, commissioners were appointed in 1798 by Virginia and Kentucky to fix the boundary. In 1799-1800 the commissioners' report was made and ratified by the States. It was as follows, viz:

To begin at the point where the Carolina; now Tennessee, line crosses the top of the Cumberland Mountains, near Cumberland Gap, thence northeastwardly along the top or highest part of the said Cumberland Mountain, keeping between the headwaters of Cumberland and Kentucky rivers, on the west side thereof, and the headwaters of Powell's and Guest's rivers, and the Pond Fork of Sandy, on the east side thereof, continuing along the said top, or highest part of said mountain, crossing the road 
leading over the saine at the Little Paint Gap, where by some it is called the Hollow Mountain and where it terminates at the West Fork of Sandy, commonly called Russell's Fork, thence with a line to be run north $45^{\circ}$ east till it intersects the other great principal branch of Sandy, commonly called the northeastwardly branch, thence down the said northeastwardly branch to its junction with the main west branch and down Main Sandy to its confluence with the Ohio. (See Shepard's Virginia, vol. 2, p. 234.)

It will be seen that the latter part of this line is the present line between West Virginia and Kentucky.

- (For the history of the settlement of the boundaries between Virginia and North Carolina, vide North Carolina, vide p. 100.)

In 1779 Virginia and North Carolina appointed commissioners to run the boundary line between the two States west of the Allegheny Mountains, on the parallel of $36^{\circ} 30^{\prime}$. The commissioners were unable to agree on the location of the parallel; they therefore ran two parallel lines two miles apart, the northern known as Henderson's, and claimed by North Carolina, the southern known as Walker's line, and claimed by Virginia. In the year 1789 North Carolina ceded to the United States all territory west of her present boundaries, and Tennessee being formed from said ceded territory, this question became one between Virginia and Tennessee.

Commissioners having been appointed by Virginia and Tennessee to establish the boundary, their report was adopted in 1803, and was as follows, viz:

A due west line equally distant from both Walker's and Henderson's, beginning on the summit of the mountain generally known as White Top Mountain, where the northeast corner of Tennessee terminates, to the top of the Cumberland Mountain, where the southwestern corner of Virginia terminates.

In 1871 Virginia passed an act to appoint commissioners to adjust this line.

Tennessee the following year, in a very emphatic manner, passed a resolution refusing to reopen a question regarding a boundary which she considered "fixed and established beyond dispute forever." (See acts of Tennessee, 1872.)

Up to 1783 Virginia exercised jurisdiction over a large tract of country northwest of the Ohio River. But by a deed executed March 1, 1784, she ceded to the United States all territory lying northwest of the Ohio River, thus making her western boundary the west bank of the Ohio River.

On the 31st of December, 1862, the State of Virginia was divided, and 48 counties, composing the western part of the State, were made the new State of West Virginia. By an act of Congress in 1866, consent was given to the transfer of two additional counties from Virginia to West Virginia.

In 1873 and 1877 commissioners were appointed by each State to determine the true boundaries between the two States, and the General 


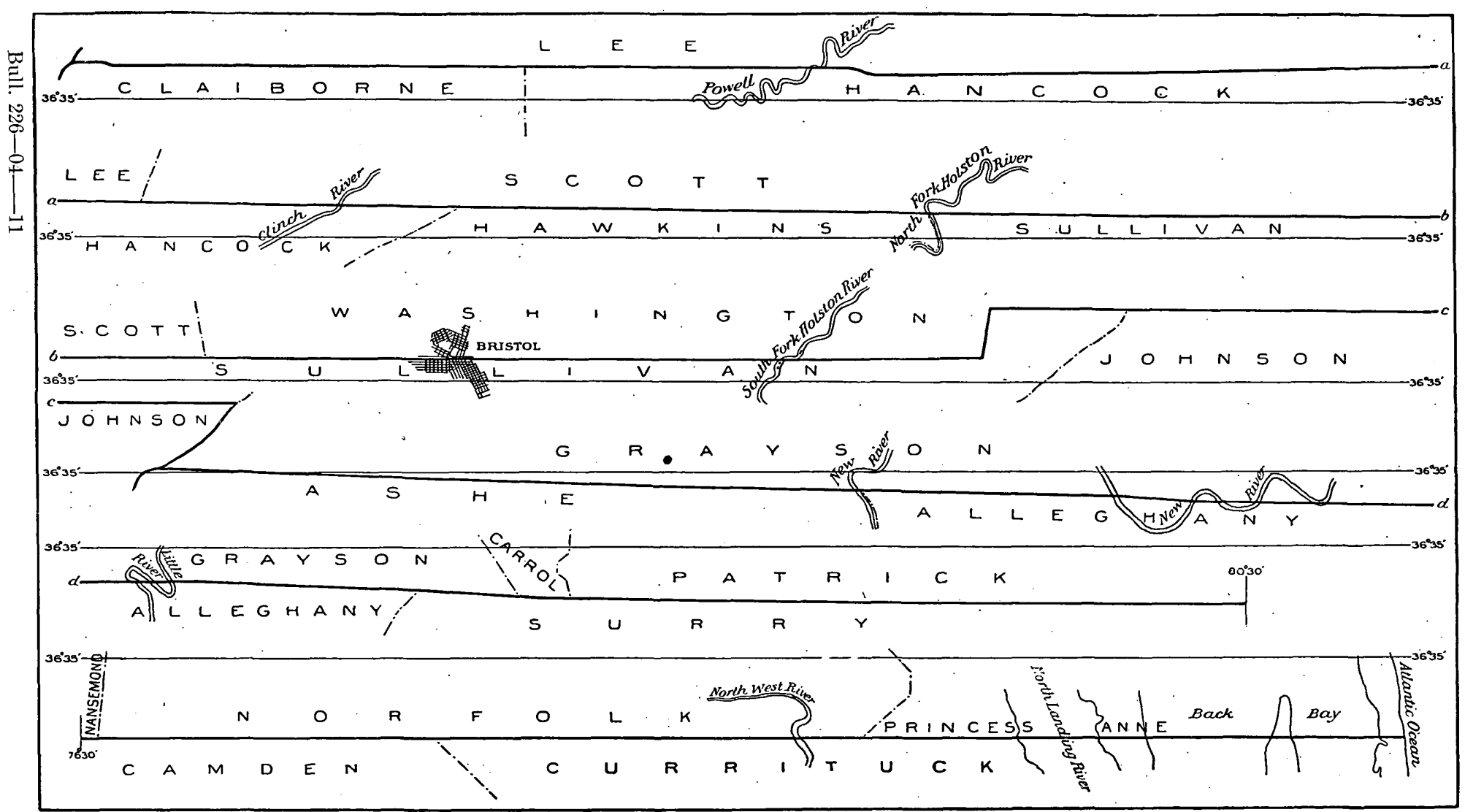


Government was asked to detail officers of engineers to act with said commissioners in surveying and fixing the line.

Until their reportis at hand the boundary can only be found by following the old county lines. In view of the expectation of such report at an early day, it has not been thought best to go into an examination of the old county lines.

\section{WEST VIRGINIA.}

This State was set off from Virginia on December 31, 1862. It was originally formed of those counties of Virginia which had refused to join in the secession movement. It was admitted to the Union as a separate State June 19, 1863. It originally contained the following counties: Barbour, Boone, Braxton, Brooke, Cabell, Calhoun, Clay, Doddridge, Fayette, Gilmer, Greenbrier, Hampshire, Hancock, Hardy, Harrison, Jackson, Kanawha, Lewis, Logan, Marion, Marshall, Mason, McDowell, Mercer, Monongalia, Monroe, Morgan, Nicholas, Ohio, Pendleton, Pleasants, Pocahontas, Preston, Putnam, Raleigh, Randolph, Ritchie, Roane,Taylor, Tucker, Tyler, Upshur, Wayne, Webster, Wetzel, Wirt, Wood, Wyoming.

In 1866 it was enlarged by the two counties of Berkeley and Jefferson, transferred from Virginia. Its boundary with Virginia is made up of boundary lines of the border counties above enumerated, and can be defined only by reference to the laws by which these counties were created. In the constitution of 1872 , after a recapitulation of the counties which were transferred from Virginia to West Virginia, is found the following clause defining the boundaries upon the south and west.

The State of West Virginia includes the bed, bank, and shores of the Ohio River and so much of the Big Sandy River as was formerly included in the Commonwealth of Virginia, and all territorial rights and property in and jurisdiction over the same heretofore reserved by and vested in the Commonwealth of Virginia are vested in and shall hereafter be exercised by the State of West Virginia, and such parts of the said beds, banks, and shores as lie opposite and adjoinıng the several counties of this State shall form parts of said several counties respectively.

(For a history of the boundaries of West Virginia; vide Pennsylvania, p. .86; Maryland, p. 89; Virginia, p. 96.)

\section{NORTH CAROLINA.}

In the year 1663 the "first charter of Carolina" was granted, which, two years later, in 1665 , was enlarged by the "second charter of Carolina."

The following extracts from these two charters define the boundaries:

Charter of Carolina, 1663.

* * * All that territory or tract of ground, scituate, lying and being within our dominions of America, extending from the north end of the island called Lucke Island, 
which lieth in the southern Virginia seas, and within six and thirty degrees of the northern latitude, and to the west as far as the south seas, and so southerly as far as the river Saint Matthias, which bordereth on the coast of Florida, and within one and thirty degrees of northern latitude, and so west in a direct line as far as the south seas aforesaid. $* * *$

\section{Charter of Carolina, 1665.}

* * All that province, territory, or tract of land, scituate, lying or being in our dominions of America, aforesaid, extending north and eastward as far as the north end of Currituck River, or inlet, upon a strait westerly line to Wyonoke Creek, which lies within or about the degrees of thirty-six and thirty minutes, northern latitude, and so west in a direct line as far as the south seas. $* * *$

This is an extension of the charter of 1663 , by which its northern boundary was removed from the approximate latitude of $36^{\circ}$ to $36^{\circ} 30^{\prime}$, on which parallel it is now approximately established. Although the exact year in which the division of the province of Carolina into the two provinces of North and South Carolina appears somewhat uncertain, I find it generally put down as 1729. The division line between the two provinces, North and South Carolina, appears to have been established by mutual agreement.

In the constitution of North Carolina of 1776 this line is defined as shown in the subjoined extract:

The property of the soil, in a free government, being one of the essential rights of the collective body of the people, it is necessary, in order to avoid future disputes, that the limits of the State should be ascertained with precision; and as the former temporary line between North and South. Carolina was confirmed and extended by commissioners appointed by the legislatures of the two States, agreeable to the order of the late King George II in conncil, that line, and that only, should be esteemed the southern boundary of this State; that is to say, beginning on the sea side at a cedar stake, at or near the mouth of Little River (being the southern extremity of Brunswic County), and running from thence a north west course through the boundary house, which stands in thirty-three degrees fifty-six minutes, to thirty-five degrees north latitude, and from thence a west course so far as is mentioned in the charter of King Charles II to the late proprietors of Carolina. Therefore, all the territory, seas, waters, and Garbours, with their appurtenances, lying between the line above described, and the southern line of the State of Virginia, which begins on the sea shore, in thirty-six degrees thirty minutes north latitude, and from thence runs west, agreeable to the said charter of King Charles, are the right and property of the people of the State, to be held by them in sovereignty, any partial line, without the consent of the legislature of this State, at any time thereafter directed or laid out in anywise notwithstanding.

On December 2, 1789, the legislature passed an act ceding to the United States its western lands, now constituting the State of 'Tennessee. On February 25, 1790, the deed was offered, and on April 2 of the same year it was accepted by the United States.

In the Revised Statutes the north and south boundaries of the State are claimed to be as follows: The northern boundary, the parallel of $36^{\circ} 30^{\prime}$; the southern boundary, a line running northwest from Goat Island on the coast in latitude $33^{\circ} 56^{\prime}$ to the parallel of $35^{\circ}$, and thence along that parallel to 'Tennessee; while the western boundary is the 
Smoky Mountains. It is strange that the Revised Statutes should contain such a statement of the boundary lines when it is thoroughly well known that it is incorrect, especially as regards the sonthern boundary. In the case of the northern boundary the intention has been from the earliest colonial times down to the present to establish a line upon the parallel of $36^{\circ} 30^{\prime}$. This is found to be the wording of every legislative act relating to it, and the errors of this boundary are due simply to errors in surveying and location. The following brief and comprehensive sketch of the north and south boundary lines of this State, and of the various attempts made to locate them, is taken from Professor Kerr's "Geology of North Carolina," Vol. I, page 2:

"The first and only serious attempt to ascertain the northern boundary was that made in 1728, by Col. Wm. Byrd, and others, commissioners on the part of the two colonies, acting under royal authority. From the account given by Byrd of this undertaking, it appears that they started from a point on the coast whose position they determined by observation to be in $36^{\circ} 31^{\prime}$, north latitude, and ran due west (correcting for the variation of the compass), to Nottoway River, where they made an offset of a half mile to the mouth of that stream, again running west. The line was run and marked 242 miles from the coast; to a point in Stokes County, on the upper waters of the Dan River: (on Peter's Creek) the North Carolina commissioners accompanying the party only about two-thirds of the distance. Beyond this point, the line was carried some 90 miles by another joint commission of the two colonies in 1749; this survey, terminating at. Steep Rock Creek, on the east of Stone Mountain, and near the present northwest corner of the State, was estimated to be 329 miles from the coast.' In 1779 the line was taken up again at a point on Steep Rock Creek, determined by observation to be on the parallel of $36^{\circ} 30^{\prime}$ (the marks of the previous survey having disappeared entirely), and carried west to and beyond Bristol, Tennessee. This last is known as the Walker line, from one of the commissioners of Virginia.

These lines were run and the latitude observations taken with very imperfect instruments, and the variation of the compass was little understood, so that it was not possible to trace a parallel of latitude. The líne, besides, was only marked on the trees and soon disappeared, and as the settlements were very scattered the location soon became a matter of vague tradition and presently of contention and litigation, so that in 1858 , at the instance of Virginia, commissioners were appointed to relocate the line from the end of the Byrd survey westward, but for some reason they did not act. In 1870 commissioners were again appointed by Virginia and similar action asked on the part of this State; and the proposition was renewed in 1871 , but ineffectually, as before. In all these numerous attempts to establish the line of division between the two colonies and States, the intention and the specific instructions have been to ascertain and mark, as the boundary of the two States, the parallel of $36^{\circ} 30^{\prime}$. The maps published towards the end of last century by Jefferson and others give that parallel as the line, and the bill of rights of North Carolina claims that "all the territory lying between the line above described (the line between North and South Carolina) and the southern line of the State of Virginia, which begins on the seashore in $36^{\circ} 30^{\prime}$ north latitude, and from thence runs west, agreeably to the charter of King Charles, are the right and property of this State." But it appears from the operations of the United States Coast Survey at both ends of the line that the point of beginning on Currituck Inlet, instead of being, as so constantly assumed, in latitude $36^{\circ} 30^{\prime}$, or as determined by the surveyors in $1728,36^{\circ}$ $31^{\prime}$ is $36^{\circ} 33^{\prime} 15^{\prime \prime}$, and the western end (of "the Walker line," of 1779 , at Bristol, Tenn.) $36^{\circ} 34^{\prime} 25.5^{\prime \prime}$. It is stated in Byrd's Journal that the variation of the com- 
pass was ascertained to be a little less than $3^{\circ} \mathrm{W}$. [The magnetic chart of the United States Coast Survey would make it $3^{\circ} \mathrm{E}$.] And no account is given of any subsequent correction, and if none was made at the end of the line surveyed by him the course would have been in error by nearly $3^{\circ}$, as the amount of variation in this State changes a little more than $1^{\circ}$ for every 100 miles of easting or westing. So that the northern boundary of the State as run is not only not the parallel of $36^{\circ} 30^{\prime}$ but is far from coincident with any parallel of latitude, and must be a succession of curves, with their concavities northward and connected at their ends by north and south offsets.

The southern boundary between this State and South Carolina and Georgia was first established by a joint colonial commission in 1735 to 1746 . The commissioners run a line from Goat Island on the coast (in latitude $33^{\circ} 56^{\prime}$ as supposed) NW. to the parallel of $35^{\circ}$, according to their observations, and then due west to within a few miles of the Catawba River, and here, at the old Salisbury and Charleston road, turned north along that road to the southeast corner of the Catawba Indian lands. This line, resurveyed in 1764, was afterwards (in 1772) continued along the eastern and northern boundaries of the Catawba lands to the point where the latter intersects the Catawba River; thence along and up that river to the mouth of the South Fork of the Catawba, and thence due west, as supposed, to a point near the Blue Ridge. This part of the line was resurveyed and confirmed by commissioners under acts of assembly of $1803,1804,1806,1813,1814$, and 1815, and continuepd west to and along the Saluda Mountains and the Blue Ridge to the intersection of the "Cherokee boundary" of 1797 , and thence in a direct line to the Chatooga River at its intersection with the parallel of $35^{\circ}$. From this point the line was run west to the Tennessee line, between this State and Georgia, in 1807, and confirmed and established by act of 1819 .

The boundary between this State and Tennessee was run, according to the course designated in the act of 1789 , entitled "An act for the purpose of ceding to the United States certain western lands therein described" (theState of Tennessee); that is, along the crest of the Smoky Mountains, from the Virginia line to the Cataluche River (in Haywood County), in 1799, under act of 1796 . It was continued from this point to the Georgia line in 1821. The commissioners who completed this line, at the date lastmentioned, instead of following their instructions, diverged from the crest of the Smoky (Unaka) Mountains at the intersection of the Hiwassee turnpike, and run due south to the Georgia line, thereby losing for the State the valuable mining region since known as Ducktown.

And as to the southern boundary, the point of beginning on Goat Island is in latitude $33^{\circ} 51^{\prime} 37^{\prime \prime}$, as shown by the coast survey, and instead of running from Goat Island northwest to latitude of $35^{\circ}$ and thence along that parallel, it appears, from the South Carolina geographical State survey of 1821-25, that the course from the starting point is $\mathrm{N}$. $47^{\circ} 30^{\prime} \mathrm{W}$., and instead of pursuing the parallel of $35^{\circ}$ it turns west about 10 miles south of that line, and then on approaching the Catawba River, turns northward pursuing a rigzag line to the forks of the Catawba River, which is about 12 miles north of that parallel; and from this point to the mountains the boundary line (of 1772 ) runs, not west, but N. $88^{\circ} \mathrm{W}$., bringing its western end about 17 miles too far north, and reaching the (supposed) parallel of $35^{\circ}$ at a distance of about 130 miles east of the Catawba River. The loss of territory resulting from these singular deviations is probably between 500 and 1,000 square miles.

The following extract from the constitution of 1796, of Tennessee, defines the eastern boundary of that State, which is the western boundary of North Carolina, as it was intended to be run and marked:

Beginning on the extreme height of the Stone Mountain at the place where the line of Virginia intersects it in latitude thirty-six degrees and thirty minutes north; 
<smiles>C1C2CC3CC1C3C2</smiles> 


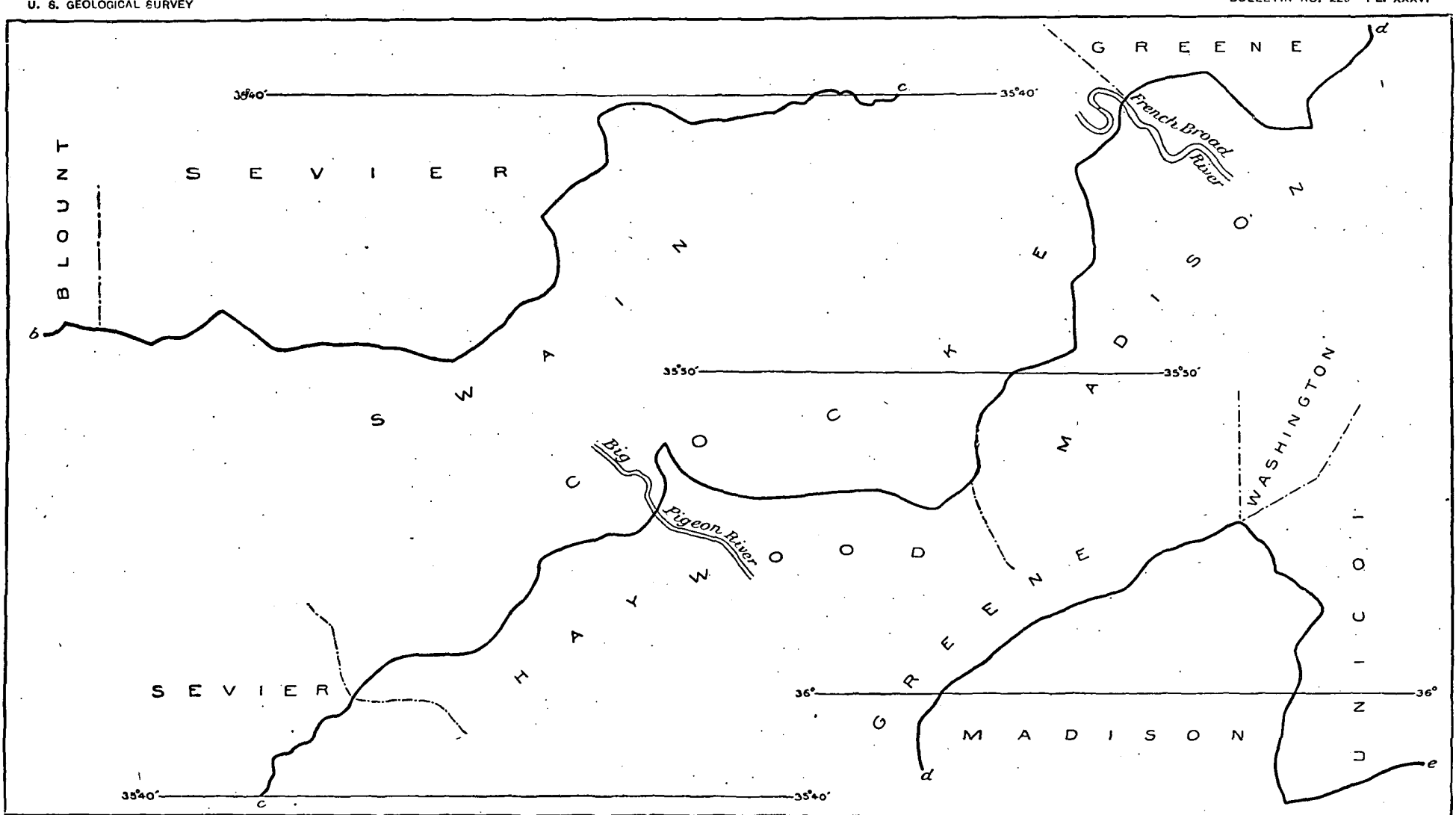

BOUNDARY BETWEEN NORTH CAROLINA AND TENNESSEE. 


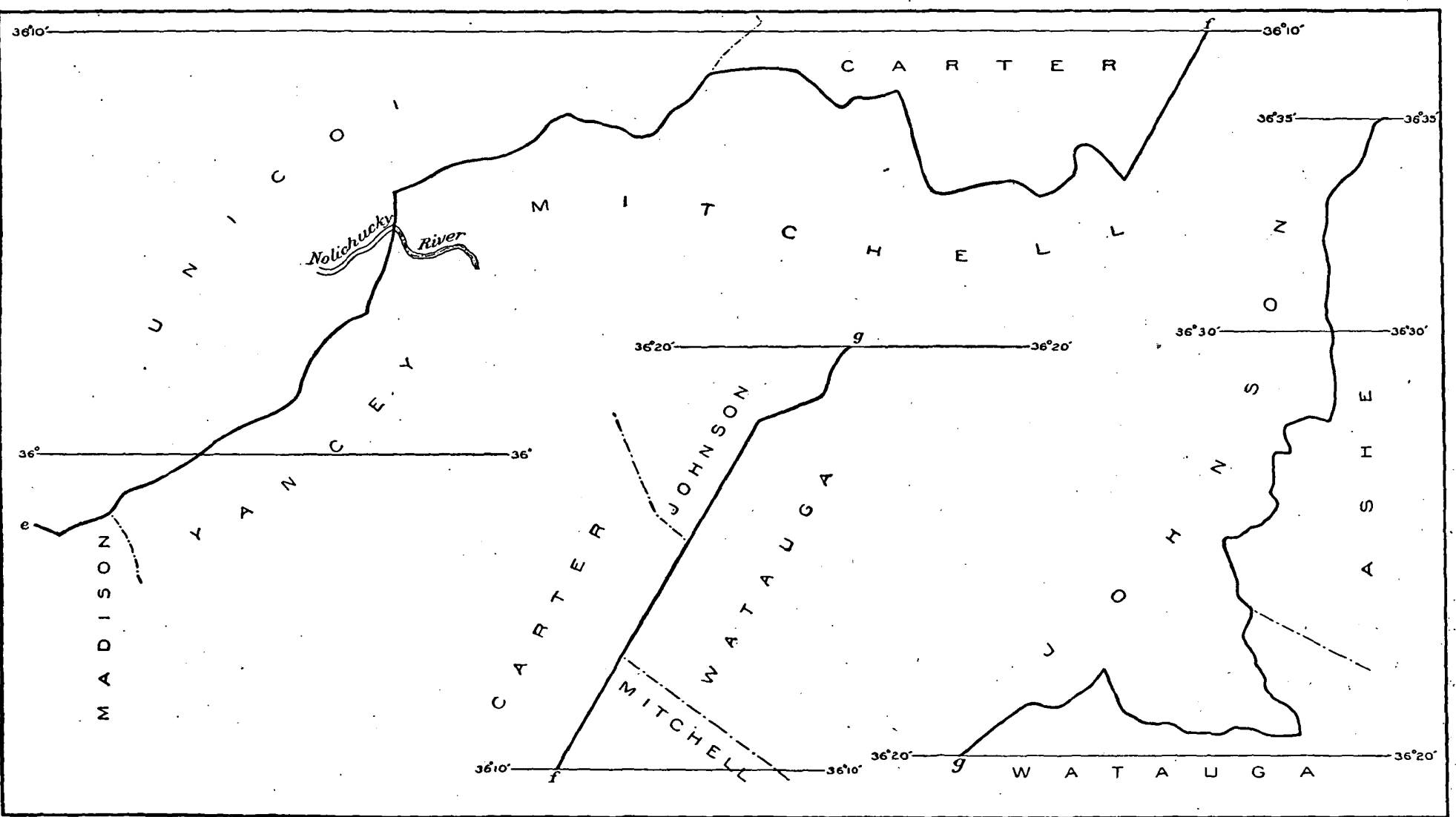


running thence along the extreme height of the said mountain to the place where Watauga River breaks through it; thence a direct course to the top of the Yellow Mountain, where Bright's road crosses the same; thence along the ridge of said mountain between the waters of Doe River and the waters of Rock Creek, to the place where the road crosses the Iron Mountain; from thence along the extreme height of said mountain to where Nolichucky River runs through the same; thence to the top of the Bald Mountain; thence along the extreme height of said mountain to the Painted Rock on French Broad River; thence along the highest ridge of said mountain to the place where it is called the Great Iron or Smoky Mountain; thence along the extreme height of said mountain to the place where it is called Unicoi or Unaka Mountain between the Indian towns of Cowee and Old Chota; thence along the main ridge of the said mountain to the southern bounday of this State as described in the act of cession of North Carolina to the United States of America.

In 1879 the legislature passed an act to appoint commissioners to make a survey from the northeast corner of Georgia westward. This point of commencement is common to North Carolina, South Carolina, and Georgia.

In 1881 the legislature passed another act providing for the appointment of a commissioner, who should act with commissioners from Virginia, South Carolina, Georgia, or Tennessee to re-run and re-mark the boundaries between North Carolina and the other States.

\section{SOUTH CAROLINA.}

The territory included in the present State of South Carolina was inclided in the charter of Carolina, which also embraced what is now the State of Georgia. (Vide North Carolina, p. 99.)

In 1729 the province of Carolina was divided, forming the two provinces of North Carolina and South Carolina. In 1732 the extent of South Carolina was reduced by the charter of Georgia. (Vide Georgia, p. 104.)

(For a history of the settlement of the boundary between North Carolina and South Carolina, vide North Carolina, p. 99.)

By the charter of Georgia the line between South Carolina and.Georgia was to be the Savannah River, to the head thereof. In 1762 difficulties having arisen concerning the interpretation of the charter, as regarded the head of the Savannah, and also the title to the lands south of the Altamaha River, Georgia made complaint to the King, who issued a proclamation in 1763 giving the lands between the Altamaha and Saint Mary's rivers to Georgia. The question of the boundary on the Savannah, however, remained unsettled until 1787, when a convention between the two States was held at Beaufort, S. C., to determine the same, and the line was fixed as at present.

The following is an extract from the articles of agreement:

The most northern branch or stream of the river Savannah from the sea or mouth of such stream to the fork or confluence of the rivers now called Tugaloo and Keowa, and from thence the most northern branch or streanı of the said river Tugaloo till it intersects the northern boundary line of South Carolina, if the said branch or stream 
of Tugaloo extends so far north, reserving all the islands in the said rivers Savannah and Tugaloo to Georgia; but if the head spring or source of any branch or stream of the said river Tugaloo does not extend to the north boundary line of South Carolina, then a west line to the Mississippi, to be drawn from the head spring or source of the said branch or stream of Tugaloo River which extends to the highest northern latitude, shall forever hereafter form the separation, limit, and boundary between the States of South Carolina and Georgia. (Laws of the United States, Vol. I, p. 466.)

In the same year South Carolina ceded to the United States a narrow strip of territory south of the North Carolina line, which she claimed, about 12 or 14 miles wide, and extending to the Mississippi River; this strip now forms the northern portion of Georgia, Alabama, and Mississippi. Georgia being thus increased in extent northwardly, the line between the two States is clearly expressed in the code of South Carolina, as follows, viz:

The Savannah River, from its entrance into the ocean to the confluence of the Tugaloo and Keowa rivers; thence by the Tugaloo River to the confluence of the Tugaloo and Chatooga rivers; thence by the Chatooga River to the North Carolina line in the thirty-fifth degree of north latitude, the line being low-water mark at the southern shore of the most northern stream of said rivers, where the middle of the rivers is broken by islands, and middle thread of the stream where the rivers flow in one stream or volume.

\section{GEORGIA.}

Georgia was included in the proprietary charter granted to the lords proprietors of Carolina in 1663 and 1665, for which a provincial charter was substituted in 1719 .

In 1732 the charter of Georgia as an independent colony was granted by King George II, of which the following is an extract:

All those lands, countrys, and territories situate, lying and being in that part of South Carolina, in America, which lies from the most northern part of a stream or river there, commonly called the Savannah, all along the sea-coast to the southward, unto the nuost southern stream of a certain other great water or river called the Altamaha, and westerly from the heads of the said rivers, respectively, in direct lines to the south seas.

This charter was surrendered in 1752 and a provincial government established. (C. \& C., p. 369 et seq.)

In 1763 the territory between the Altamaha and Saint Mary's rivers was added to Georgia by royal proclamation. (Vide South Carolina, p. 103.)

In the constitution adopted by Georgia in 1798 the boundaries are declared. The following is an extract therefrom:

The limits, boundaries, jurisdictions, and authority of the State of Georgia do, and did, and of right ought to extend from the sea or mouth of the river Savannah along the northern branch or stream thereof, to the fork or confluence of the rivers now called Tugalo and Keowee, and from thence along the most nortlern branch or stream of the said river Tugalo, till it intersect the northern boundary line of South Carolina, if the said branch or stream of Tugalo extends so far north, reserving all the 


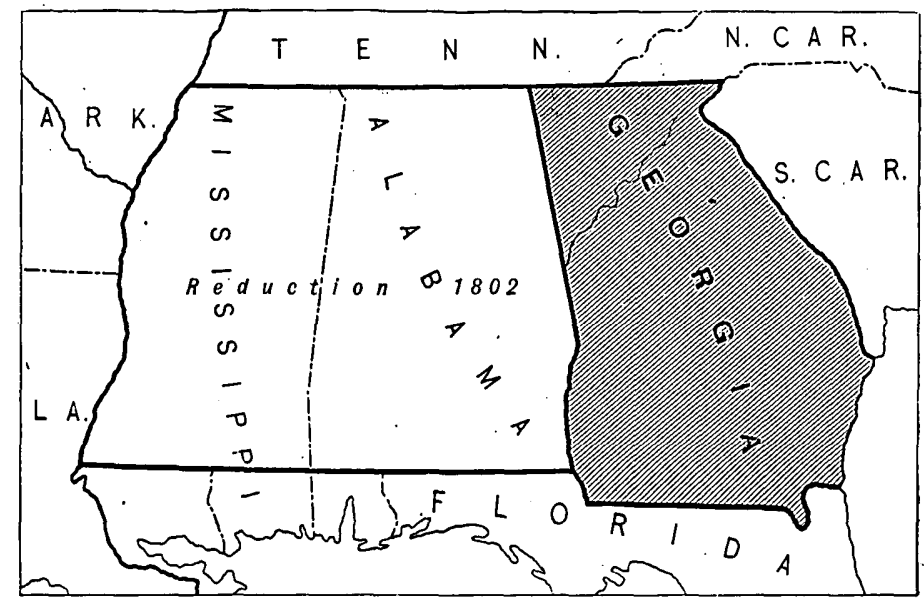

HISTORICAL DIAGRAM OF GEORGIA.

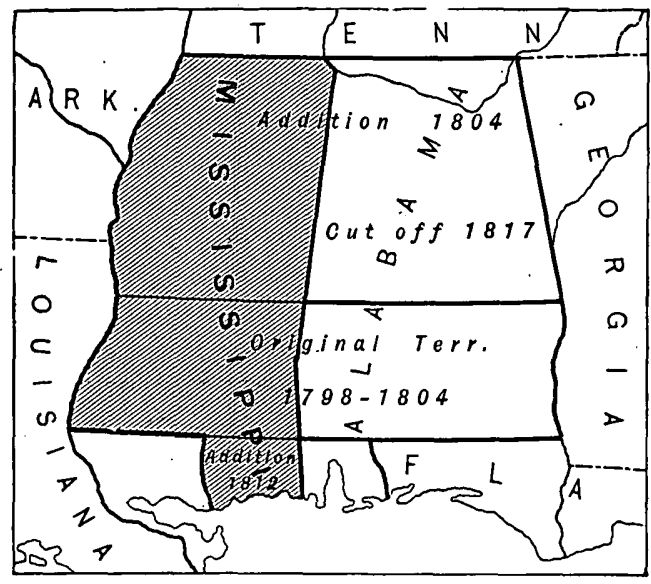

HISTORICAL DIAGRAM OF MISSISSIPPI. 
islands in the said rivers Savannah and Tugalo to Georgia; but if the head, spring, or source of any branch or stream of the said river Tugalo does not extend to the north boundary line of South Carolina, then a west line to the Mississippi, to be drawn from the head, spring, or source of the said branch or stream of Tugalo River, which extends to the highest northern latitude; thence down the middle of the said river Mississippi until it shall intersect the northernmost part of the thirty-first degree of north latitude, south by a line drawn due east from the termination of the line last mentioned, in the latitude of thirty-one degrees north of the equator, to the middle of the river Apalachicola or Chatahoochee; thence along the middle thereof, to its junction with Flint River; thence straight to the head of Saint Mary's River, and thence, along the middle of Saint Mary's River, to the Atlantic Ocean, and from thence to the mouth or inlet of Savannah River, the place of beginning, including and comprehending all the lands and waters within the said limits, boundaries, and jurisdictional rights; and also all the islands within twenty leagues of the seacoast.

In. 1802 Georgia entered into articles of agreement and cession with the United States, whereby Georgia ceded to the United States the lands west of her present boundaries, and the United States ceded to Georgia that part of the South Carolina cession of 1787 which lies east of the present western boundary of Georgia. The following extracts show the limits of the two cessions:

The State of Georgia cedes to the United States all the right, title, and claim which the said State has to the jurisdiction and soil of the lands situated within the boundaries of the United States, south of the State of Tennessee and west of a line beginning on the western bank of the Chatahouchee River where the same crosses the boundary line between the United States and Spain; running thence up the said river Chatahouchee, and along the western bank thereof to the great bend thereof, next above the place where a certain creek or river, called "Uchee" (being the first considerable stream on the western side, above the Cussetas and Coweta towns), empties into the said Chatahouchee River; thence in a direct line to Nickajack, on the Tennessee River; thence crossing the said last-mentioned river, and thence running up the said Tennessee River and along the western bank thereof to the southern boundary line of the State of Tennessee.

$$
\text { * * * * * * * * * * * * * * * * * * * * }
$$

The United States *** cede to the State of Georgia **** the lands * * * situated south of the southern boundaries of the States of Tennessee, North Carolina, and South Carolina, and east of the boundary line herein above described as the eastern boundary of the territory ceded by Georgia to the United States.

For a history of the boundary between Georgia and South Carolina, vide South Carolina, p. 103.

The history of the boundary between North Carolina and Georgia has already been given (vide North Carolina, p. 100). It may be proper, however, to add that this line (the thirty-fifth degree of north latitude) was fixed by the cession, above detailed, from the United States to Georgia of that part of the South Carolina cession east of the present western boundary of Georgia.

A long controversy ensued between Georgia and North Carolina, with no results, however, until in 1810 Georgia empowered her governor to employ Mr. Andrew Ellicott to ascertain the true location of

Bull. 226-04-12 
the thirty-fifth degree of latitude. Ellicott did so, and the point fixed by him was acquiesced in. (Vide Cobb's Georgia Digest, p. 150.)

The boundary between Georgia and Tennessee was established in 1818 , and is as follows, viz, the thirty-fifth parallel of north latitude, beginning and ending as follows:

Beginning at a point in the true parallel of the thirty-fifth degree of north latitude, as found by James Cormack, mathematician on the part of the State of Georgia, and James S. Gaines, mathematician on the part of the State of Tennessee, on a rock about two feet high, four inches thick, and fifteen inches broad, engraved on the

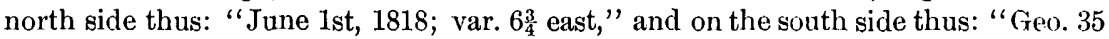
North; J. Cormack," which rock stands one mile and twenty-eight poles from the south bank of the Tennessee River, due south from near the center of the old Indian town of Nickajack, and near the top of the Nickajack Mountain, at the supposed corner of the State of Georgia and Alabama; thence running due east, leaving old D. Ross two miles and eighteen yards in the State of Tennessee, and leaving the house of John Ross about two hundred yards in the State of Georgia, and the house of David McNair one mile and one-fourth of a mile in the State of Tennessee, with blazed and mile-marked trees, lessening the variation of the compass by degrees, closing it at the termination of the line on the top of the Unicoi Mountain at five and one-half degrees. (Vide C. Stat. of Tenn., pp. 243-244.)

The boundary between Georgia and Florida was fixed by the treaty of 1783 , between the United States and Great Britain, substantially as at present, viz: Commencing in the middle of the Apalachicola or Catahouche River, on the thirty-first degree of north latitude; thence along the middle thereof to its junction with the Flint River; thence straight to the head of Saint Marys River, and thence down along the middle of Saint Marys River to the Atlantic Ocean. (Vide treaty of 1783.) This boundary was affirmed by the treaty of 1795 between the United States and Spain, and commissioners were appointed to run the entire line between the United States and the Spanish territory. (Vide treaty of 1795.)

In 1819 Spain ceded the Floridas to the United States. In 1822 Florida was made a Territory, and in 1825 was admitted into the Union as an independent State.

In 1826 Congress took action as indicated below:

UNITED STATES STATUTES AT LARGE, NINETEENTH CONGRISS, SESSION I, 1826.

AN ACT to authorize the President of the United States to run and mark a line dividing the Territory of Florida from the State of Georgia.

The line shall be run straight from the junction of said rivers Chatahoochie and Flint, to the point designated as the head of Saint Marys River.

This boundary line was long unsettled, a controversy arising concerning the true point to be considered to be the head of the Saint Marys River, as Georgia contended that the point fixed upon by the Spanish and American commissioners under the treaty of 1795 was incorrect. This line was run in 1825 by the General Land Office. 
In 1859 commissioners were appointed by Georgia and Florida to rerun the line. Florida ratified their report in 1861, and Georgia in 1866.

The detailed report of the commissioners is not at hand, but the line is declared in the Statutes of Georgia, as follows, viz:

From a point on the western bank of the Chattahochee River in the 31st degree of north latitude; thence along the line or limit of high-water mark to its junction with the Flint River; thence along a certain line of survey made by Gustavus J. Orr, a surveyor on the part of Georgia, and W. Whitner, a surveyor on the part of Florida, beginning at a four-and-aft tree, about four chains below the present junction; thence along this line east, to a point designated thirty-seven links north of Ellicotts Mound on the St. Marys River; thence along the middle of said river to the Atlantic Ocean. (Vide Code of Ga., 1873, p. 7.)

This line is also given in the Code of Florida, and differs in one respect, viz, from the thirty-first degree of north latitude down the middle of said river to its confluence with the Flint River, etc. (Vide Code of Florida, 1872.)

The line between Georgia and Alabama was fixed by the act of cession of Georgia to the United States in 1802 .

In 1822-25, Georgia desiring to have the line run from the Chattahoochee to where it strikes the Tennessee line, appointed commissioners for that-purpose, and requested the cooperation of Alabama and the United States, both, however, failing to take action. The Georgia commissioners ran the line from Nickajack, on the Tennessee line, to Millers Bend, on the Chattahoochee. (For a history of the controversy concerning this line, vide Laws of Georgia, 1822-24-25-26.)

Alabama protested against the above line and made repeated efforts to reopen negotiations concerning it, to all of which Georgia sturdily refused to accede, until finally, January 24, 1840, the legislature of Alabama passed the following joint resolution, viz:

Resolved, That the State of Alabama will, and do, hereby accept, as the true dividing line between this State and that of Georgia, the line which was run and marked out by the commissioners of Georgia in 1826, beginning at what is called Millers Bend, on the Chattahoochee River; thence along said marked line to Nickajack.

The line is given in the Code of Alabama in the following words, viz:

The boundary line between Alabama and Georgia commences on the west side of the Chattahoochee River at the point where it enters the State of Florida; from thence up the river, along the western bank thereof, to the point on Millers Bend next above the place where the Uchee Creek empties into such river; thence in a direct line to Nickajack. (See Code of Alabama, 1876, p. 189.)

In James's Handbook of Georgia, 1876, p. 121, is the following description of the western boundary of Georgia, viz:

From Nickajack the line between Georgia and Alabama runs south $9^{\circ} 30^{\prime}$ east to Millers Bend, on the Chattahoochee River, about 146 miles; thence down the western bank of the river at high-water mark to its junction with Flint River, at a point now four chains below the actual junction, latitude $30^{\circ} 42^{\prime} 42^{\prime \prime}$, longitude $80^{\circ} 53^{\prime} 15^{\prime \prime}$. 
FLORIDA.

Florida was originally settled by the Spaniards, and was held as a Spanish province nearly two hundred years. In 1762 it was ceded by Spain to Great Britain, who divided it into the two provinces of East and West Florida, separated by the Apalachicola River, with a northein boundary substantially as at present. (Vide Fairbanks' History of Florida.)

In 1783 Great Britain retroceded Florida to Spain, and the northern boundary was fixed by the treaty of peace between the United States and Great Britain signed in the same year. Spain, however, claimed the territory as far north as the parallel of latitude of the mouth of the Yazoo River,

Previous to this, in 1763, France had ceded Louisiana to Spain, which Spain retroceded to France in 1800, and in 1803 France ceded the same to the United States, who claimed that the eastern boundary of the said province of Louisiana, so often ceded, was the Perdido River, while Spain claimed it to be the Iberville River and Lakes Maurepas and Pontchartrain. The controversy arising from the difference of interpretation of these various treaties and cessions was terminated by the treaty of Washington in 1819, whereby Spain ceded to the United States the provinces of East and West Florida.

On March 30, 1822, by an act of Congress, the territory ceded to the United States by Spain was made the "Territory of Florida," embracing the same extent as does the present State.

On March 3, 1845, Florida was admitted into the Union as an independent State.

(For a history of the northern boundary of Florida vide Georgia, p. 104.)

In 1831 Congress passed an act relating to the boundary between Florida and Alabama, of which the following in an extract:

AN ACT to ascertain and mark the line between the State of Alabama and the Territory of Florida, and the northern boundary of the State of Illinois, and for other purposes.

That the President of the United States be, and he is hereby, authorized to cause to be run and marked the boundary line between the State of Alabama and the Territory of Florida, by the surveyors-general of Alabama and Florida, on the thirtyfirst degree of north latitude.

(Vide U. S. Stat. at Large, Vol. IV, p. 479.)

In 1847 the agreement of commissioners previously appointed by Florida and Alabama was ratified, and the line is described as follows, viz:

Commencing on the Chattahoochee River near a place known as "Irwin's Mills" and running west to the Perdido, marked throughout by blazes on the trees, and also by mounds of earth thrown up on the line at distances of one mile, more or less, from each other, and commonly known as "Ellicott's Line," or the "Mound Line.: (Vide Florida Code, 1873, p. 100.) 
This line was run in 1799-1800 by A. Ellicott. The line was retraced, remeasured; and marked in $1853-54$.

The line between the two .States is given in general terms in the Florida Code as follows, viz:

Commencing at the mouth of the Perdido River, from thence up the middle of said river to where it intersects the south boundary line of the State of Alabama and the thirty-first degree of north latitude; then due east to the Chattahoochee River.

\section{ALABAMA.}

In 1798 the United States formed the Territory of Mississippi, including-

All that tract of country bounded on the west by the Mississippi, on the north by a line to be drawn due east from the mouth of the Yasous to the Chattahouchee River, on the east by the Chattahouchee River, and on the south by the thirty-first degree of north latitude. (Vide U. S. Stat. at Large, Vol. I, p. 549.)

In this act was a clause reserving the right of Georgia and of indi viduals to the jurisdiction of the soil thereof.

South Carolina and Georgia having ceded to the United States their claim to territory west of their present limits, the General Government, in 1804, by an act of Congress, annexed the tract of country lying north of Mississippi Territory and south of the State of Tennessee, and bounded on the east by Georgia and west by Louisiana, to the Territory of Mississippi. (Vide U. S. Stat. at Large, Vol. II, p. 305.) Also in 1812 the United States added to Mississippi Territory all the lands lying east of Pearl River, west of the Perdido and south of the thirtyfirst degree of latitude. (Vide U. S. Stat. at Large, Vol. II, p. 734.) By these additions the Territory of Mississippi was made to comprise what is now included in the two States of Alabama and Mississippi. On March 8, 1817, by an act of Congress the territory of Alabama was formed from the eastern portion of the Territory of Mississippi, with the following boundaries, viz:

Beginning at the point where the line of the thirty-first degree of north latitude intersects the Perdido River; thence east to the western boundary line of the State of Georgia; thence along said line to the southern boundary line of the State of Tennessee; thence west along said boundary line to the Tennessee River; thence up the same to the mouth of Bear Creek; thence by a direct line to the northwest corner of Washington County; thence due south to the Gulf of Mexico; thence eastwardly, including all the islands within 6 leagues of the shore, to the Perdido River; and thence up the same to the beginning. (Vide U. S. Stat. at Large, Vol. III, p. 371.)

On December 14, 1819, Alabama was admitted as an independent State, with the above boundaries. It was, however, made the duty of the surveyor of the public lands south of Tennessee and the surveyor of lands in Alabama Territory to run and cut out the line of demarcation between the two States of Alabama and Mississippi, and if it should appear to said surveyors that so much of the line designated as running due south from the northwest correr of Washington County 
to the Gulf of Mexico should enroach on the counties of Wayne, Greene, and Jackson, in the State of Mississippi, then the same should be altered, so as to run in a direct line from the northwest corner of Washington County to a point on the Gulf of Mexico 10 miles east of the mouth of the River Pascagoula. (Vide U. S. Stat. at Large, Vol. III, p. 490.) This line was run and marked in 1820 .

(For the history of the boundaries between Alabama and' Georgia vide Georgia, p. 104. For the history of the boundaries between Ala. bama and Florida vide Florida, p. 108.)

The boundary between Alabama and Tennessee is the thirty-fifth parallel of north latitude (vide North Carolina, p. 102), from Nickajack (vide Georgia, p. 104) west across the Tennessee River, and on to the second intersection of said river by said parallel. ( Tide Alabama Code, 1876 , p. 189.)

The boundary between Alabama and Mississippi was to be run by surveyors, under the act of admission of Alabama. The report of said surveyors is not at hand, but the line as laid down in the Mississippi Code is as follows, viz:

Beginning at a point on the west bank of the Tennessee River, six four-pole chains south of and above the mouth of Yellow Creek; thence up the said river to the mouth of Bear Creek; thence by a direct line to what was formerly the northwest corner of Washington County, Alabama; thence in a direct line to a point ten miles east of the Pascagoula River, on the Gulf of Mexico. (Vide Mississippi Code, pp. $48,49$.

\section{MISSISSIPPI.}

(For the early history of the extent of Mississippi Territory vide Alabama, p. 109.)

On December 10, 1817, the western part of the Mississippi Territory was made a State and admitted into the Union, with the following boundaries, viz:

Beginning on the river Mississippi at the point where the southern boundary of the State of Tennessee strikes the same; thence east along the said boundary line to the Tennessee River; thence up the same to the mouth of Bear Creek; thence by a direct line to the north west corner of the county of Washington; thence due south to the Gulf of Mexico; thence westwardly, including all the islands within six leagues of the shore, to the most eastern junction of Pearl River with Lake Borgne; thence up said river to the thirty'-first degree of north latitude; thence west along said degree of latitude to the Mississippi River; thence up the same to the beginning. (Vide U. S. Stat. at Large, Vol. III, p. 348.)

(For further information concerning eastern boundary, vide Alabama, p. 109.)

In 1819 the line between Mississippi and Tennessee was run by commissioners. Their report is not at hand. In 1833 the legislature of Tennessee passed an act establishing "Thompson's line." The details of "Thompson's line" bave not been found. In 1837 the line was again 
run by commissioners from the two States and ratified by the legis. latures. The commissioners' report was as follows:

Commencing at a point on the west bank of the Tennessee River six four-pole chains south, or above the mouth of Yellow Creek, and about three-quarters of a mile north of the line known as "Thompson's line," and twenty-six chains and ten links north of Thompson's line at the basis meridian of the Chickasaw surveys, and terminating at a point on the east bank of the Mississippi River (opposite Cow Island) sixteen chains north of Thompson's line. (See Laws of Tennessee, 1837, p. 27.)

The boundaries were fixed by the act of Congress admitting the State of Mississippi, as follows, viz:

Commencing at the most eastern junction of Pearl River with Lake Borgne, thence up said Pearl River to the thirty-first degree of north latitude, thence west along said degree of latitude to the Mississippi River, thence up the same to the point where the southern boundary of Tennessee strikes the same. (See U. S. Laws, vol. 6, p. 175.)

Mississippi claims to the middle of the Mississippi River, where the river forms her western boundary. (See Rev. Stat., 1857.)

\section{LOUISIANA.}

The original territory of Louisiana was acquired from France. (See p. 19.) In 1804 a portion of this, comprising the area of the present State of Louisiana, with the exception of the southeastern portion, immediately adjoining the present State of Florida, was organized into a Territory under the name of Orleans, while the balance of the Louisiana purchase retained the name of Louisiana Territory.. On April 30,1812, the Territory of Orleans was admitted as a State under the name of Louisiana, and at the same time the name of the Territory of Louisiana was changed to Missouri Territory. In the same year the limits of the State were enlarged in the southeast to its present boundaries.

The following act defines the Territory of Orleans:

All that portion of country, ceded by France to the United States under the name of Louisiana, which lies south of the Mississippi Territory, and of an east and west line to commence on the Mississippi River at the thirty-third degree of north latitude, and to extend west to the western boundary of the said cession, shall constitute a Territory of the United States, under the name of the Territory of Orleans. (Eighth Congress, first session.)

The following clause from the act admitting Louisiana defines its original boundaries:

Beginning at the mouth of the river Sabine; thence by a line to be drawn along the middle of said river, including all islands, to the thirty-second degree of latitude; thence due north to the northernmost part of the thirty-third degree of north latitude; thence along the said parallel of latitude to the river Mississippi; thence down the said river to the river Iberville, and from thence along the middle of the said river and lakes Maurepas and Pontchartrain to the Gulf of Mexico; thence, bounded by the said Gulf, to the place of beginning, including all islands within three leagues of the coast. (Twelfth Congress, first session.) 
The following is a description of the addition to the State of Louisiana in terms of the act:

Beginning at the junction of the Iberville with the river Mississippi, thence along the middle of the Iberville, the river Amite, and of the lakes Maurepas and Pontchartrain, to the eastern mouth of the Pearl River; thence up the eastern branch of Pearl River to the thirty-first degree of north latitude; thence along the said degree of latitude to the river Mississippi; thence down the said river to the place of beginning, shall become and form a part of the State of Louisiana. (Twelfth Congress, first session.)

The north boundary of Louisiana was surveyed by a joint commission of the State and the United States.

TEXAS.

Texas declared its independence of Mexico in 1835. On December 29,1845 , it was admitted to the Union. As originally constituted, it embraced, besides its present area, the region east of the Rio (xrande, now in New Mexico, extending north to the forty-second parallel, its eastern limits coinciding with the western limit of the United States, as laid down in the treaty with Spain of 1819. (See "Texas accession," p. 23.)

In 1848 the eastern boundary of the State was extended slightly, as noted in the following act:

$B e$ it enacted by the Senate and House of Representatives of the United States of America in Congress assembled, That this Congress consents that the legislature of the State of Texas may extend her eastern boundary so as to include within her limits one-half of Sabine Pass, one-half of Sabine Lake, also one-half of Sabine River, from its mouth as far north as the thirty-second degree of north latitude.

In 1850 the State sold to the General Government for the sum of $\$ 10,000,000$ that part lying north of the parallel of $36^{\circ} 30^{\prime}$, and that portion lying west of longitude $103^{\circ}$, as far south as the parallel of $32^{\circ}$, as set forth in the following clause from the act of Congress relating to this transfer:

First. The State of Texas will agree that her boundary on the north shall commence at the point at which the meridian of one hundred degrees west from Greenwich is intersected by the parallel of thirty-six degrees thirty minutes north latitude, and shall run from said point due west to the meridian of one hundred and three degrees west from. Greenwich; thence her boundary shall run due south to the thirtysecond degree of north latitude; thence on the said parallel of thirty-two degrees of north latitude to the Rio Bravo del Norte, and thence with the channel of said river to the Gulf of Mexico. (Thirty-first Congress, first session.)

\section{The following act defines the northern boundary of Texas:}

AN ACT to authorize the President of the United States, in conjunction with the State of Texas, to - run and mark the boundary lines between the Territories of the United States and the State of Texas.

Beginning at the point where the one hundreth degree of longitude west from Greenwich crosses Red River, and running thence north to the point where said one hundreth degree of longitude intersects the parallel of thirty-six degrees thirty minutes north latitude, and thence west with the said parallel of thirty-six degrees 


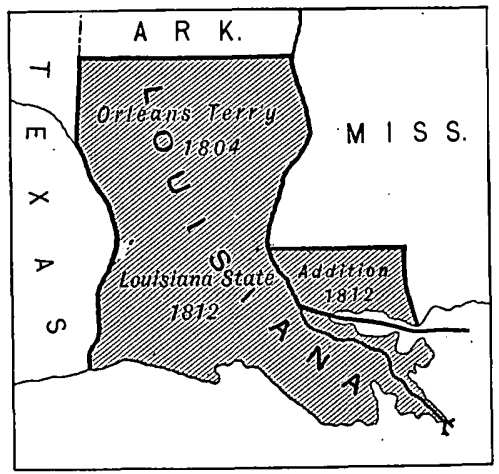

HISTORICAL DIAGRAM OF LOUISIANA.

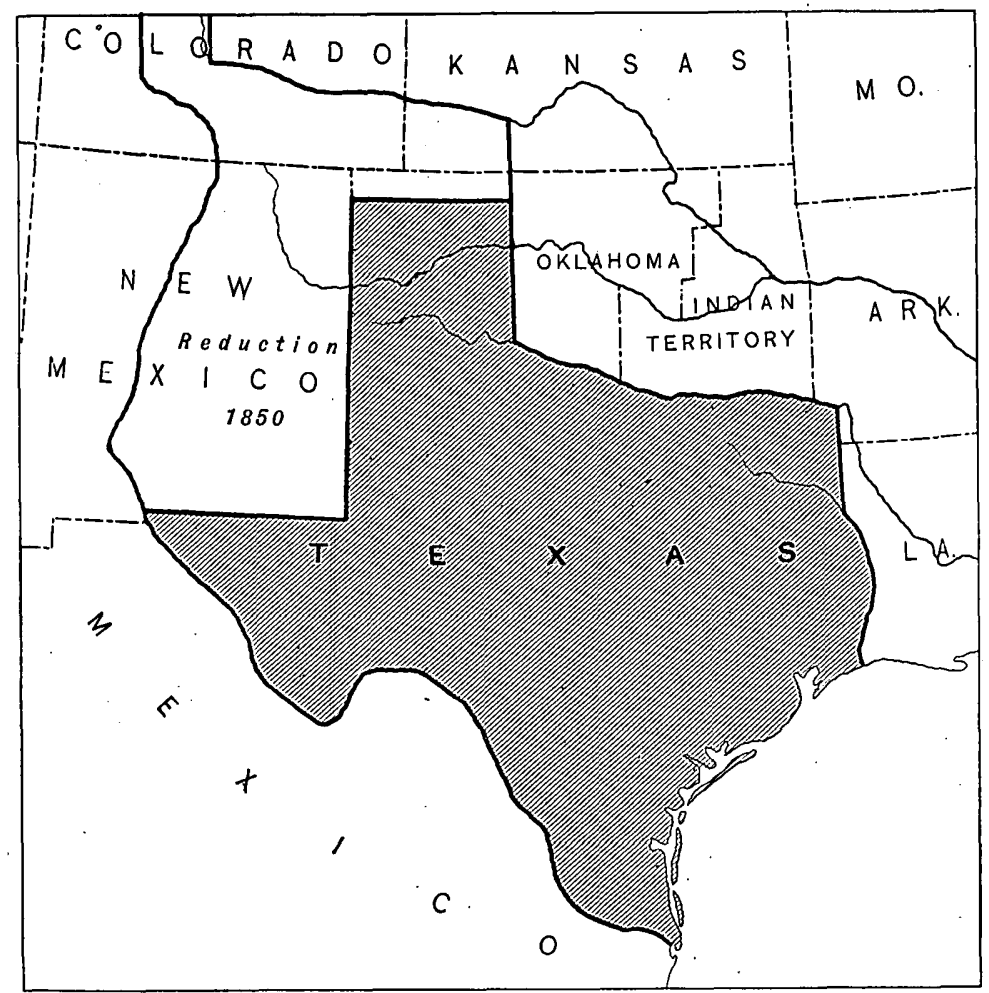

HISTORICAL DIAGRAM OF TEXAS. 
and thirty minutes north latitude to the point where it intersects the one hundred and third degree of longitide west from Greenwich; and thence south with the said one hundred and third degree of longitude to the thirty-second parallel of north latitude; and thence west with said thirty-second degree of north latitude to the Rio Grande. (Thirty-fifth Congress, first session.)

The boundary line of Texas is as follows: Beginning in the Gulf of Mexico, at the outlet of Sabine Lake, the line passes northward through the middle of Sabine Lake and up the middle of Sabine River to the point where said river intersects the parallel of $32^{\circ}$; thence north along the meridian of that point of intersection to the point where said meridian intersects Red River; thence up Red River to the one hundredth meridian west of Greenwich; thence north on said meridian to the parallel of $36^{\circ} 20^{\prime}$; west on said parallel to the meridian of $103^{\circ}$ west of Greenwich; thence south on said meridian to the parallel of latitude of $32^{\circ}$; thence west on that parallel to its point of intersection with the Rio Grande; thence down the mid-channel of the Rio Grande to its mouth.

That portion of the east boundary between Red River and the Sabine was run and marked by a joint commission of the United States and Texas in 1841 .

The boundary lines between Texas and New Mexico were run and marked in 1859-60, under the Department of the Interior.

\section{ARKANSAS.}

The Territory of Arkansas or Arkansaw, as it was originally spelled, was formed on March 2, 1819, from a part of Missouri Territory. The following clause from the act establishing it defines its limits in part:

All that part of the Territory of Missouri which lies south of a line beginning on the Mississippi River at thirty-six degrees north latitude, running thence west to the river St. François, thence up the same to thirty-six degrees thirty minutes north latitude, and thence west to the western Territorial boundary line, shall, for the purposes of a Territorial government, constitute a separate Territory and be called the Arkansaw Territory.

In 1824 an act was passed by Congress fixing the western boundary of the Territory. This was as follows:

AN ACT to fix the western boundary line of the Territory of Arkansas, and for other purposes.

The western boundary line of the Territory of Arkansas shall begin at a point forty miles west of the southwest corner of the State of Missouri and run south to the right bank of the Red River, and thence down the river and with the Mexican boundary to the line of the State of Louisiana.

Four years later, in 1828 , the following act was passed defining its southern boundary:

AN ACT to authorize the President of the United States to run and mark a line dividing the Territory of Arkansas from the State of Louisiana.

Commencing on the right bank of the Mississippi River at latitude thirty-three degrees north and running due west on that parallel of latitude to where a line running due north from latitude thirty-two degrees north on the Sabine River will intersect the same. 
The south boundary was originally run in 1823, and again in 1843-45, by a joint commission of the two States of Arkansas and Missouri.

The same year the following treaty changed materially the western line of the Territory, placing it in its present position:

TREATY WITH TTHE CHEROKEE INDIANS MAY 28, 1828.

Article 1. The western boundary of Arkansas shall be, and the same is, hereby defined, viz: A line shall be run, commencing on Red River at the point where the Eastern Choctaw line strikes said river, and run due north with said line to the river Arkansas; thence in a line to the southwest corner of Missouri.

The Eastern Choctaw line, referred to above, starts on the Arkansas River "one hundred paces west of Fort Smith, and thence due south to the Red Kiver." (Treaty with Choctaw Nation, January 20, 1825.)

This part of the west boundary was run and marked in 1825, and that part from Fort Smith to the southwestern corner of Missouri in 1831. The entire western boundary was resurveyed and re-marked in 1877.

Arkansas was admitted as a State June 15, 1836.

The following extracts from the enabling act, and from various constitutions, give statements of the boundaries, differing slightly from one another, but, for the most part, only in wording:

CONSTITUTION OF ARKANSAS, 1836.

Beginning in the middle of the main channel of the Mississippi River on the parallel of 36 degrees north latitude; running from thence west with the parallel of latitude to the Saint Francis River; thence up the middle of the main channel of said river to the parallel of thirty-six degrees thirty minutes north; from thence west to the southwest corner of the State of Missouri; and from thence to be bounded on the west to the north bank of Red River, as by acts of Congress and treaties heretofore defining the western limits of the Territory of Arkansas, and to be bounded on the south side of Red River by the Mexican boundary line to the northwest corner of the State of Louisiana; thence east by the Louisiana State line to the middle of the main channel of the Mississippi River; thence up the middle of the main channel of said river to the thirty-sixth degree of north latitude, the point of beginning.

Again, in the enabling act for Arkansas, 1836 (Twenty-fourth Congress, first session), the boundaries are found to be defined as follows:

Beginning in the middle of the main channel of the Mississippi River, on the parallel of thirty-six degrees north latitude, running from thence west, with the said parallel of latitude, to the St. Francis River; thence up the middle of the main channel of said river to the parallel of thirty-six degrees thirty minutes north; from thence west to the southwest corner of the State of Missouri; and from thence to be bounded on the west, to the north bank of Red River, by the line described in the first article of the treaty between the United States and the Cherokee Nation of Indians, west of the Mississippi, made and concluded at the city of Washington, on the twenty-sixth day of May, in the year of our Lord one thousand eight hundred and twenty-eight; and to be bounded on the south side of Red River by the Mexican boundary line to the northwest corner of the State of Louisiana; thence east with the Louisiana State line to the middle of the main channel of the Mississippi River; thence up the middle of the main channel of the said river to the thirty-sixth degree of north latiture, the point of beginning. 


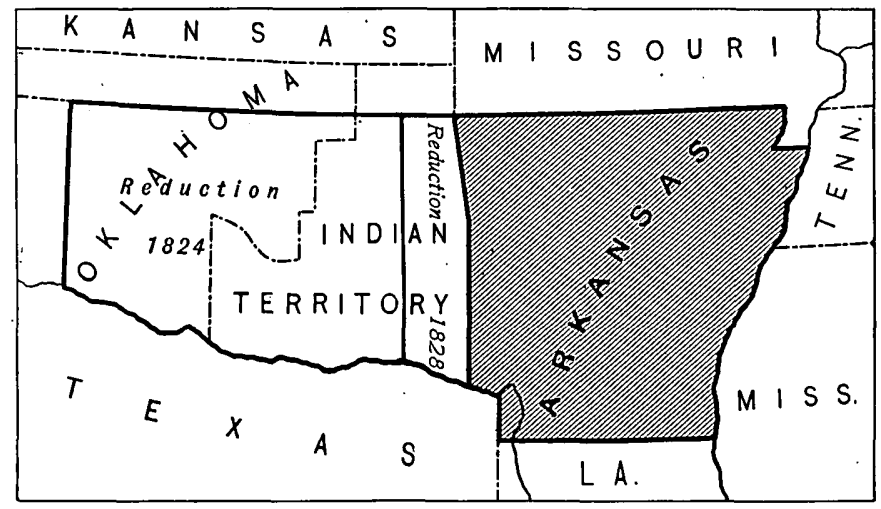

HISTORICAL DIAGRAM OF ARKANSAS.

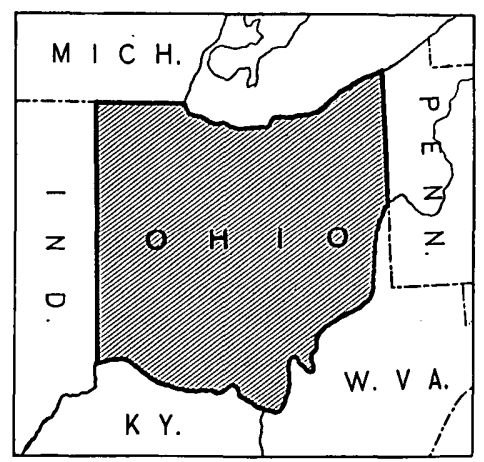

HISTORICAL DIAGRAM OF OHIO. 
In the constitution of 1864 the boundaries are defined as follows:

Beginning in the middle of the Mississippi River, on the parallel of thirty-six degrees north latitude, to the St. Francis River; thence up the middle of the main channel of said river to the parallel of thirty-six degrees thirty minutes north; thence west to the southwest corner of the State of Missouri; and from thence to be bounded on the west to the north bank of Red River, as by acts of Congress of the United States, and the treaties heretofore defining the western limits of the Territory of Arkansas; and to be bounded on the south side of Red River by the boundary line of the State of Texas, to the northwest corner of the State of Louisiana; thence east with the Louisiana State line to the middle of the main channel of the Mississippi River; thence up the middle of the main channel of said river to the thirty-sixth degree of north latitude, the point of beginning.

The constitution of 1868 differs but slightly from the last. It is as follows:

Beginning at the middle of the main channel of the Mississippi River, on the parallel of $36^{\circ}$ north latitude, running from thence west, with the said parallel of latitude, to the Saint Francis River; thence up the middle of the main channel of said river to the parallel of $36^{\circ} 30^{\prime}$ north; from thence west with the boundary line of the State of Missouri to the southwest corner of that State; and thence to be bounded on the west to the north bank of Red River, as by acts of Congress and treaties heretofore defining the western limits of the Territory of Arkansas; and to be bounded on the south side of Red River by the boundary line of the State of Texas to the northwest corner of the State of Louisiana; thence east with the Louisiana State line to the middle of the main channel of the Mississippi River; thence up the middle of the main channel of said river, including an island in said river known as "Belle Point Island," to the $36^{\circ}$ of north latitude, the place of beginning.

In the constitution of 1874 there are again slight differences, mainly in wording:

Beginning at the middle of the main channel of the Mississippi River, on the parallel of thirty-six degrees of north latitude; running thence west with said parallel of latitude to the middle of the main channel of the Saint Francis River; thence up the main channel of said last-named river to the parallel of thirty-six degrees thirty minutes of north latitude; thence west with the southern boundary line of the State of Missouri to the southwest corner of said last-named State; thence to be bounded on the west to the north bank of Red River, as by act of Congress and treaties existing January 1, 1837, defining the western limits of the Territory of Arkansas and to be bounded across and south of Red River by the boundary line of the State of Texas as far as to the north west corner of the State of Louisiana; thence easterly with the northern boundary line of said last-named State, to the middle of the main channel of the Mississippi River; thence up the middle of the main channel of said last-named river, including an island in said river known as "Belle Point Island," and all other land originally surveyed and included as a part of the Territory or State of Arkansas to the thirty-sixth degree of north latitude, the place of beginning.

TENNESSEE.

Tennessee was originally a part of North Corolina. '(For further information vide North Carolina, p. 99.)

In 1790 it was ceded to the United States. Its boundaries described in the act of cessian are, substantially, those of the present day. 
On June 1, 1796, by an act of Congress it was admitted into the Union.

The act of admission declares its boundaries as, "All the territory ceded by North Carolina."

(For the history of the eastern boundary, vide North Carolina, p. 99; for the southern boundary, vide Georgia, p. 104, - ' labama, p. 109, and Mississippi, p. 110.)

The Mississippi River forms its western boundary u.der the treaty of peace of 1783 .

The line which divided Virginia and North Carolina was the southern boundary of Kentucky. Virginia and North Carolina, prior to the creation of the States of Kentucky and Tennessee, appointed commissioners-Messrs. Walker and Henderson-to run and mark the line on the parallel of latitude $36^{\circ} 30^{\prime}$. From a point on the top of the Cumberland Mountains, now the southeastern corner of Kentucky, Walker ran and marked the line to a point on the Tennessee River. This line, called Walker's line, was regarded for many years as the dividing line between Kentucky and Tennessee. It was ascertained, however, that Walker's line was north of latitude $36^{\circ} 30^{\prime}$.

The Indian title to the land west of the Tennessee River being extinguished by the treaty of 1819 , the legislature appointed Robert Alexander and Luke Munsell to ascertain the true point of latitude $36^{\circ} 30^{\prime}$ on the Mississippi River, and to run and mark a line east on that parallel, which was done as far east as the Tennessee River. (For above, see Gen. Stat. Ky., 1873, p. 167.)

In 1820 commissioners were appointed by Kentucky and Tennessee, respectively, to settle the boundary. Their report was ratified, and is as follows, viz:

Axr. I. The line of bourdary and separation between the States of Kentucky and Tennessee shall be as follows, viz:

The line run by the Virginia commissioners in the year 1779-80, commonly called Walker's line, as the same is reputed, understood, and acted upon by the said States, their respective officers and citizens, from the southeastern corner of Kentucky to the Tennessee River; thence with and up said river to the point where the line of Alexander and Munsell, run by them in the last year under the authority of an act of the legislature of Kentucky entitled "An act to run the boundary line between this State and the State of Tennessee, west of the Tennessee River, approved Feb. 8,1819 ," would cross said river, and thence with the said line of Alexander and Munsell to the termination thereof on the Mississippi River below New Madrid.

Then follow nine other articles.

Article III provides for running and marking the line at any subsequent time. (See General Stat. Kentucky, page 170.)

In 1858-59 commissioners were appointed by Kentucky and Tennessee to run this line.

The detailed report of the commission on the part of Tennessee can be found in Statutes of Tennessee, 1871, Vol. I, pages 223-243, giving courses, bearings, milestones erected, and a map of the boundary. 


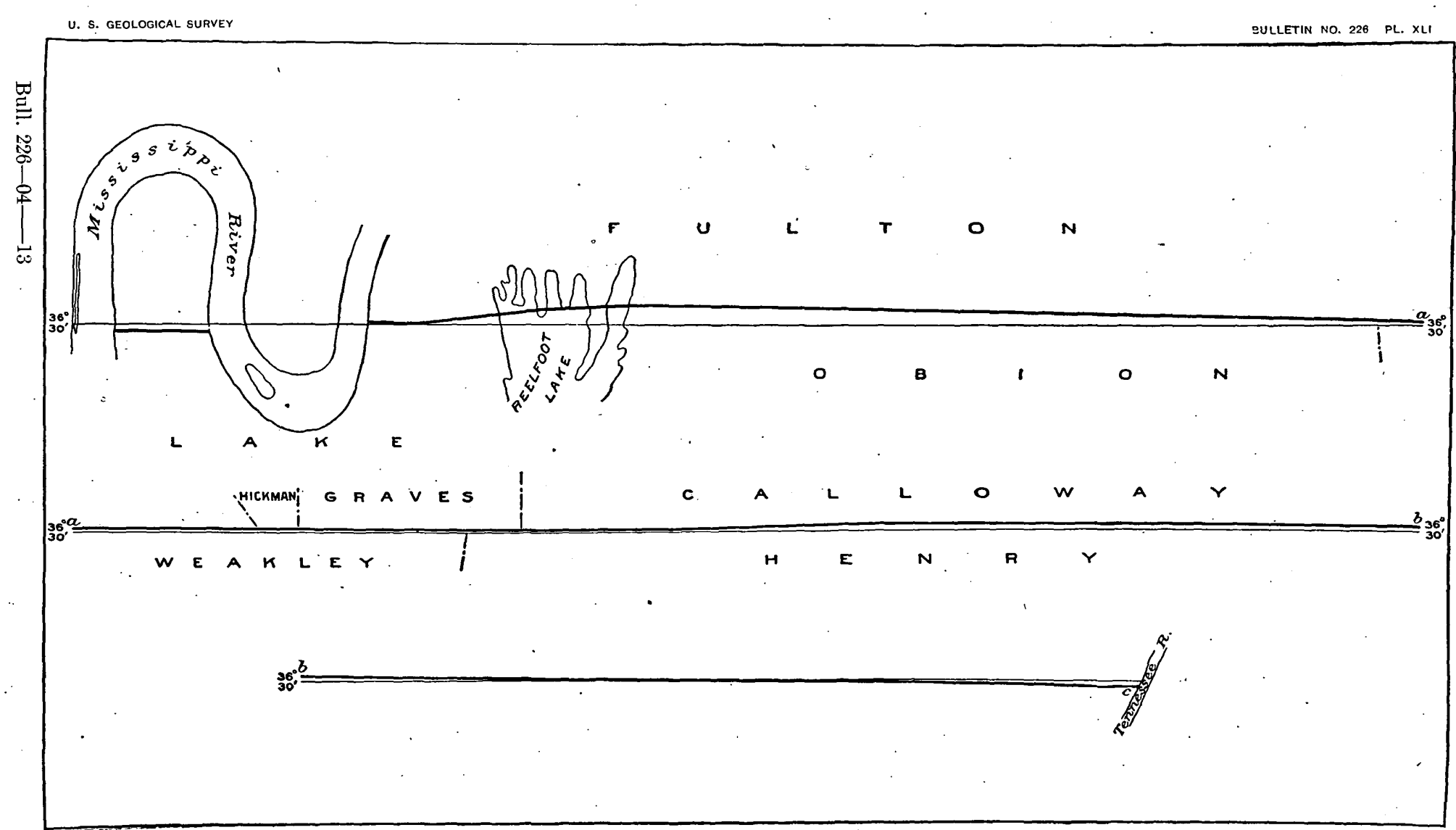

BOUNDARY BETWEEN KENTUCKY AND TENNESSEE. 


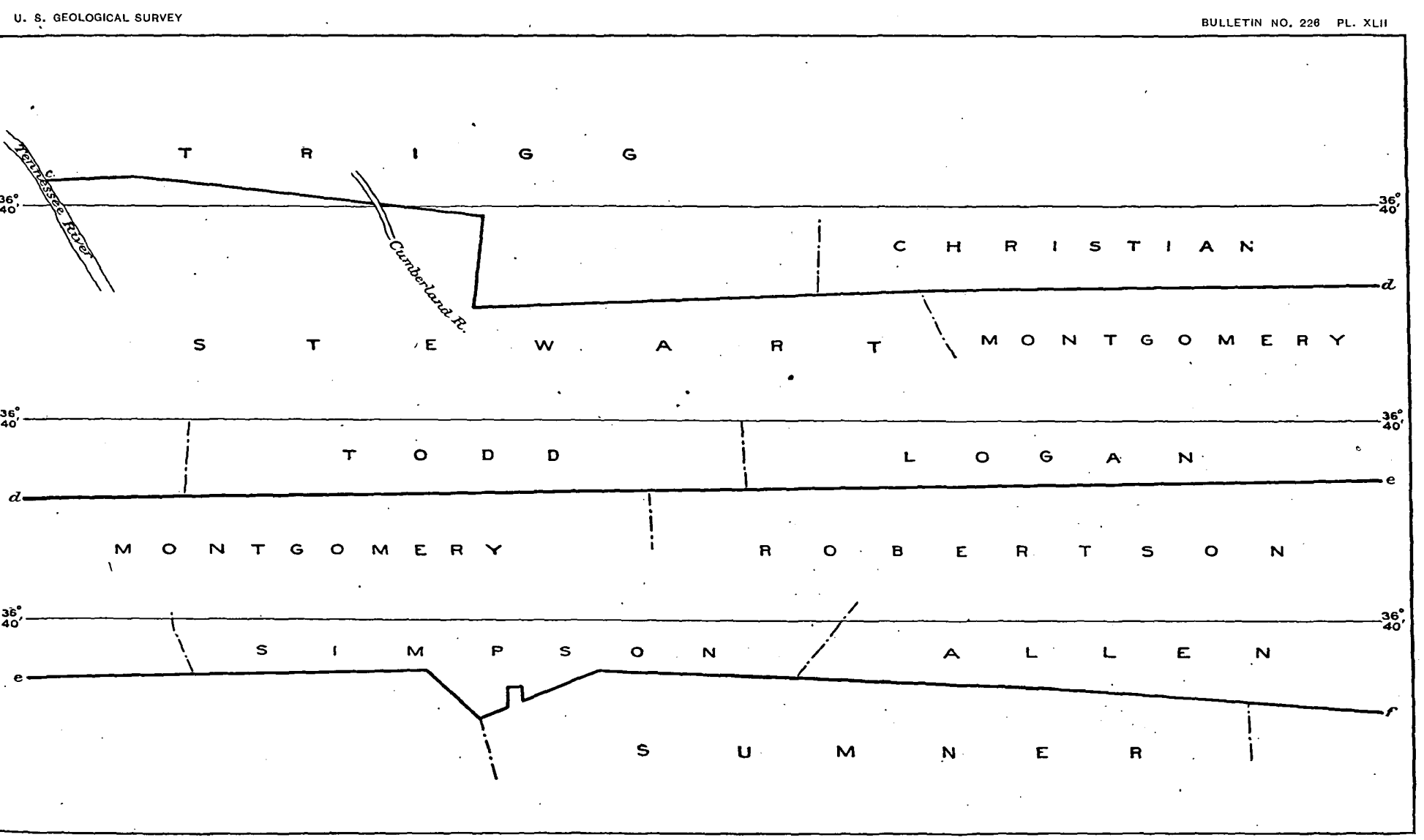




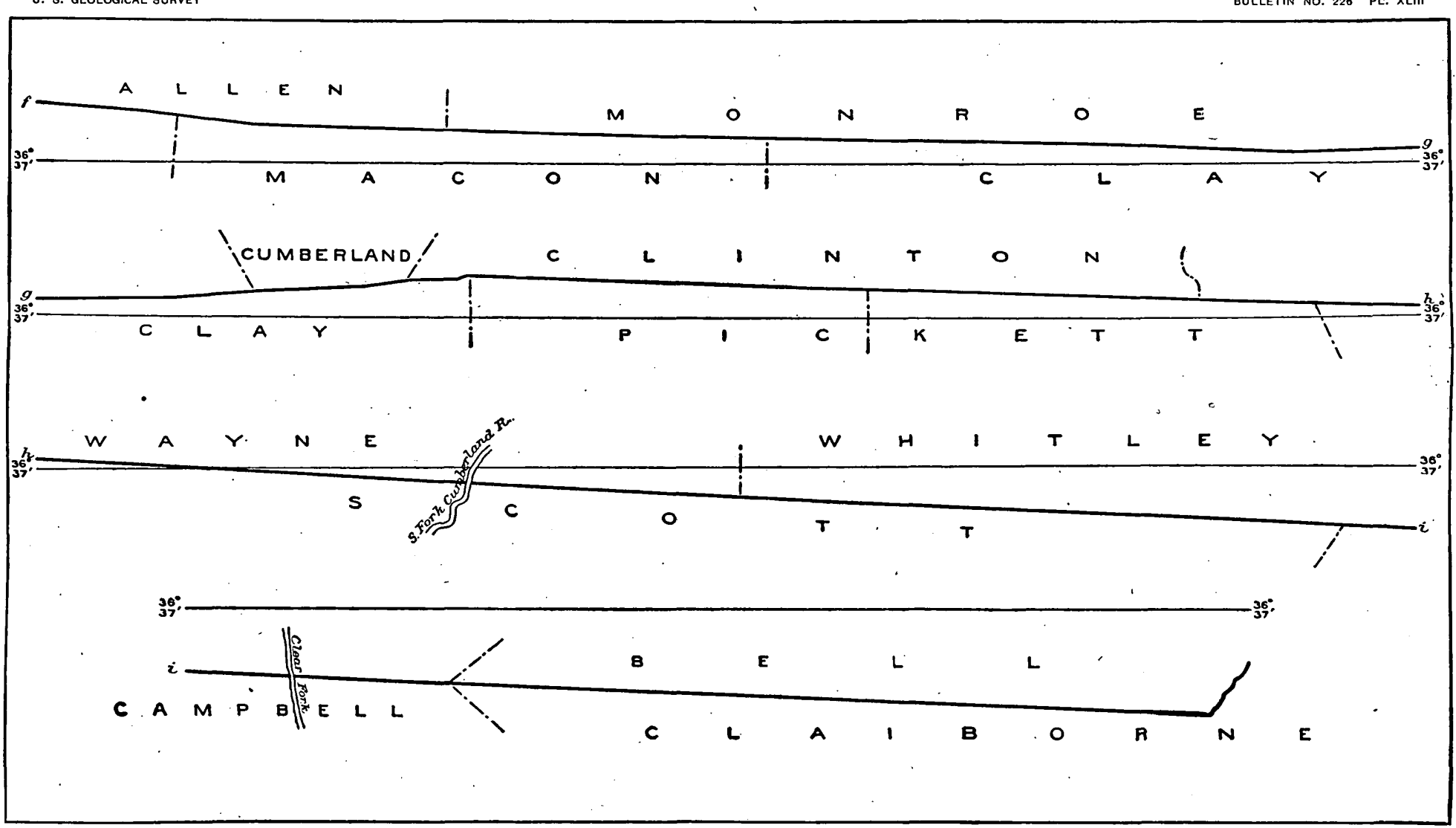


The report of this commission on the part of Kentucky was published at Frankfort by the State printer, 1860, in a pamphlet of 98 octavo pages, with latitudes and a map of the line, on a scale of 1:108,000.

For a history of the boundary between Virginia and Tennessee, vide Virginia, p. 95.)

\section{KENTUCKY.}

Kentucky was included in the original limits of Virginia, and was a part of the county of Augusta. Augusta County was formed in 1738. In 1769 Botetourt County was created from a portion of Augusta County; in 1772, Fincastle from Botetourt; in 1776, Kentucky from Fincastle.

The boundaries of all these counties may be found in Hening's Laws of Virginia, Vols. I to IX.

In 1789 Virginia passed an act giving her consent that the county of Kentucky, within her jurisdiction, should be formed into a new State. Accordingly, June 1, 1792, Kentucky was admitted into the Union, with substantially her present boundaries.

By the cession of 1784, by Virginia to the United States, of the territory northwest of the Ohio River, this river became the northwest boundary of the State of Kentucky.

The western boundary, the Mississippi, was fixed by the treaty of peace in 1783.

(For a history of the boundary between Kentucky and Virginia and West Virginia, vide Virginia, p. 95; for the boundary between Kentucky and Tennessee, vide Tennessee, p. 115.)

OHIO.

Ohio was the first State formed from the original Territory Northwest of the River Ohio. It was admitted as a State on November 29, 1802, with limits given in the enabling act as follows:

Bounded on the east by the Pennsylvania line, on the south by the Ohio River to the mouth of the Great Miami River, on the west.by the line drawn due north from the mouth of the Great Miami aforesaid, and on the north by an east and west line drawn through the southerly extreme of Lake Michigan, running east after intersecting the due north line aforesaid, from the mouth of the Great Miami until it shall intersect Lake Erie or the Territorial line, and thence with the same through Lake Erie to the Pennsylvania line aforesaid: Provided, That Congress shall be at liberty. at any time hereafter either to attach all the territory lying east of the line to be drawn due north from the mouth of the Miami aforesaid to the Territorial line, and north of an east and west line drawn through the southerly extreme of Lake Michigan, running east as aforesaid to Lake Erie, to the aforesaid State, or dispose of it otherwise, in conformity to the fifth article of compact between the original States and the people and States to be formed in the territory northwest of the river Ohio. (Seventh Congress, first session.)

In the constitution of Ohio of 1802, Article VII, the boundaries are defined as follows:

Bounded on the east by the Pennsylvania line; on the south by the Ohio River to the mouth of the Great Miami River; on the west by the line drawn due north from 
the mouth of the Great Miami aforesaid, and on the north by an east and west line drawn through the southerly extreme of Jake Michigan, running east after intersecting the due north line aforesaid from the mouth of the Great Miami until it shall intersect Lake Erie or the Territorial line; and thence with the same through Lake Erie to the Pennsylvania line aforesaid; provided always, and it is hereby fully understood and declared by this convention, that if the southerly bend or extreme of Lake Michigan should extend so far south that a line drawn due east from it should not intersect Lake Erie, or if it should intersect the said Lake Erie east of the mouth of the Miama River of the Lake, then, and in that case, with the assent of the Congress of the United States, the northern boundary of this State shall be established by, and extending to, a direct line running from the southern extremity of Lake Michigan to the most northerly cape of the Miami Bay, after intersecting the due north line from the mouth of the Great Miami River as aforesaid; thence northeast to the Territorial line, and by the said Territorial line to the Pennsylvania line.

In accordance with the provisions in the enabling act, and in the first constitution of the State, the northern boundary of the State was changed so that, instead of running on a parallel drawn from the southern extremity of Lake Michigan, it followed the arc of a great circle drawn from the southern extremity of Lake Michigan to the most northern cape of Maumee ("Miami") Bay.

Following are the texts of the acts providing for the examination of the northern boundary and making the change in the boundary:

AN ACT to provide for the taking of certain observations preparatory to the adjustment of the northern boundary line of the State of Ohio.

That the President of the United States cause to be ascertained, by accurate observation, the latitude and longitude of the soutberly extreme of Lake Michigan; and that he cause to be ascertained, by like observation, the point on the Miami of the lake which is due east therefrom, and also the latitude and longitude of the most northerly cape of the Miami Bay; alco, that he cause to be ascertained, with all practicable accuracy, the latitude and longitude of the most southerly point in the northern boundary line of the United States in Lake Erie, and also the points at which a direct line drawn from the southerly extreme of Lake Michigan to the most southerly point in said northern boundary line of the United States will intersect the Miami River and Bay; and also that he cause to be ascertained, by like observation, the point in the Mississippi which is due west from the southerly extreme of Lake Michigan; and that the said observations be made and the result thereof returned to the proper Department within the current year. (Twenty-second Congress, first session, 1832.)

AN ACT to establish the northern boundary line of the State of Ohio, and to provide for the admission of the State of Michigan into the Union.

The northern boundary line of the State of Ohio shall be established at and shall be a direct line drawn from the southern extremity of Lake Micbigan to the most northerly cape of the Maumee (Miami) Bay after that line, so drawn, shall intersect the eastern boundary line of the State of Indiana; and from the said north cape of the said bay northeast to the boundary line between the United States and the province of Upper Canada, in Lake Erie, and thence, with the said last-mentioned line, to its intersection with the western line of the State of Pennsylvania. (Twentyfourth Congress, first session, 1836.)

The northern boundary was originally surveyed in 1817 . The western boundary was surveyed in the same year from old Fort Recovery 


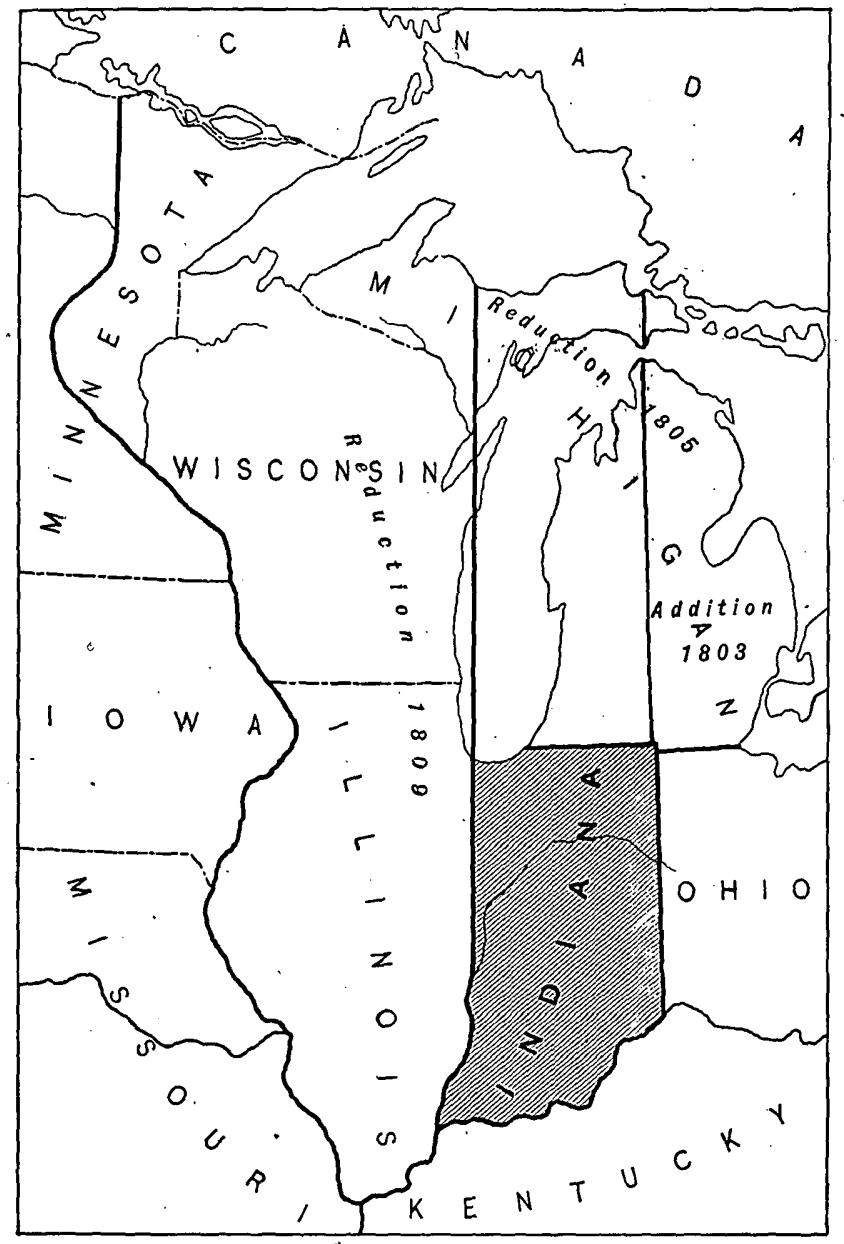

HISTORICAL DIAGRAM OF INDIANA. 
to the northwestern corner. South of Fort Recovery this boundary was surveyed as the first principal meridian. of the General Land Office.

\section{INDIANA.}

By the act passed in the year 1800 , to take effect on and after the 4th day of July of that year, the Territory Northwest of the River Ohio was divided into two parts, the eastern part to retain the old name, the western part to become the Territory of Indiana.

Under this act the Territory of Indiana was organized. The description of the boundary line between these two Territories is given in the following act establishing them:

That from and after the fourth day of July next all that part of the territory of the United States northwest of the Ohio River, which lies to the westward of a line begining at the Ohio, opposite to the mouth of Kentucky River, and running thence to Fort Recovery, and thence north until it shall intersect the territorial line between the United States and Canada, shall, for the purpose of temporary government, constitute a separate Territory, and be called Indiana Territory.

SEC. 5. That whenever that part of the territory of the United States which lies to the eastward of a line beginning at the mouth of the Great Miami River, and running thence due north to the territorial line between the United States and Canada, shall be erected into an independent State, and admitted into the Union on an equal.footing with the original States, thenceforth said line shall become and remain permanently the boundary line between such State and the Indiana Territory, anything in this act contained to the contrary notwithstanding. (Sixth Congress, first session.)

Ohio was admitted in 1802 . Its western boundary, a meridian through the mouth of the Miami River, left. a narrow strip of country between Ohio and the Territory of Indiana, which was by a clause in the enabling act of Ohio added to Indiana Territory. The following is the clause in question:

SEC. 3. All that part of the territory of the United States northwest of the river Ohio heretofore included in the eastern division of said 'lerritory, and not included within the boundary herein prescribed for the said State, is hereby attached to and -made a part of the Indiana Territory.

On the 30 th of June, 1805 , the northern portion of Indiana Territory was cut off and organized as Michigan Territory. (For the divisional line between these, see Michigan, p. 120.)

On March 1, 1809, Indiana Territory was divided, and the western portion of it organized as Illinois Territory. (For a description of the divisional line between these two Territories, see Illinois, p. 120.) On December 11, 1816, Indiana was admitted as a State with the limits.as given in the following extract from the enabling act, which have not since been changed:

AN ACT to enable the people of the Indiana Territory to form a constitution and state government and for the admission of such State into the Union on an equal footing with the original States.

The said State shall consist of all the territory included within the following boundaries, to wit: Bounded on the east by the meridian line which forms the western boundary of the State of Ohio; on the south by the river Ohio from the 
mouth of the Great Miami River to the mouth of the River Wabash; on the west by a line drawn along the middle of the Wabash from its mouth to a point where a due north line drawn from the town of Vincennes would last touch the northwestern shore of the said river; and from thence by a due north line, until the same shall intersect an east and west line drawn through a point 10 miles north of the southern extreme of Lake Michigan; on the north by the said east and west line until the same shall intersect the first-mentioned meridian line which forms the western boundary of the State of Ohio. (Fourteenth Congress, first session.)

The north boundary of Indiana was surveyed and marked in 1827, and its west boundary by a joint commission of the two States, Indiana and Illinois.

\section{ILLINOIS.}

Illinois Territory, originally part of the Territory Northwest of the River Ohio, and subsequently a part of Indiana Territory, was organized on March 1, 1809. The following clause from the act separating it from Indiana Territory defines its boundary:

AN ACT for dividing the Indiuna Territory into two separate governments.

From and after the first day of March next, all that part of the Indiana Territory which lies west of the Wabash River and a direct line drawn from the said Wabash River and Post Vincennes due north to the territory line between the United States and Canada shall, for the purpose of temporary government, constitute a separate Territory and be called Illinois. (Tenth Congress, second session.)

On December 3, 1818, it was admitted as a State, with its present boundaries. The enabling act defines these boundaries as follows:

AN ACT to enable the people of the Illinois Territory to form a constitution and State government, and for the admission of such State into the Union on an equal footing with the original States.

The said State shall consist of all the territory included within the following boundaries, to wit: Beginning at the mouth of the Wabash River; thence up the same and with the line of Indiana to the north west corner of said State; thence east with the line of the same State to the middle of Lake Michigan; thence north along the middle of said lake to north latitude forty-two degrees thirty minutes; thence west to the middle of the Mississippi River; and thence down along the middle of that river to its confluence with the Ohio River; and thence up the latter river along its northwestern shore to the beginning. (Fifteenth Congress, second session.)

The northern boundary of Illinois was run and marked in 1832-3.

\section{MICHIGAN.}

Michigan was organized as a Territory June 30, 1805, from the northern part of Indiana Territory.

The following clause from the act dividing Indiana Territory defines its limits:

From and after the thirtieth day of June next all that part of the Indiana Territory which lies north of a line drawn east from the southerly bend or extreme of Lake Michigan, until it shall intersect Lake Erie, and east of a line drawn from the said southerly bend through the middle of said lake to its northern extremity, and thence due north to the northern boundary of the United States, shall, for the purpose of temporary government, constitute a separate Territory, and be called Michigan. (Eighth Congress, second session.)

This line was run and marked in 1827. 


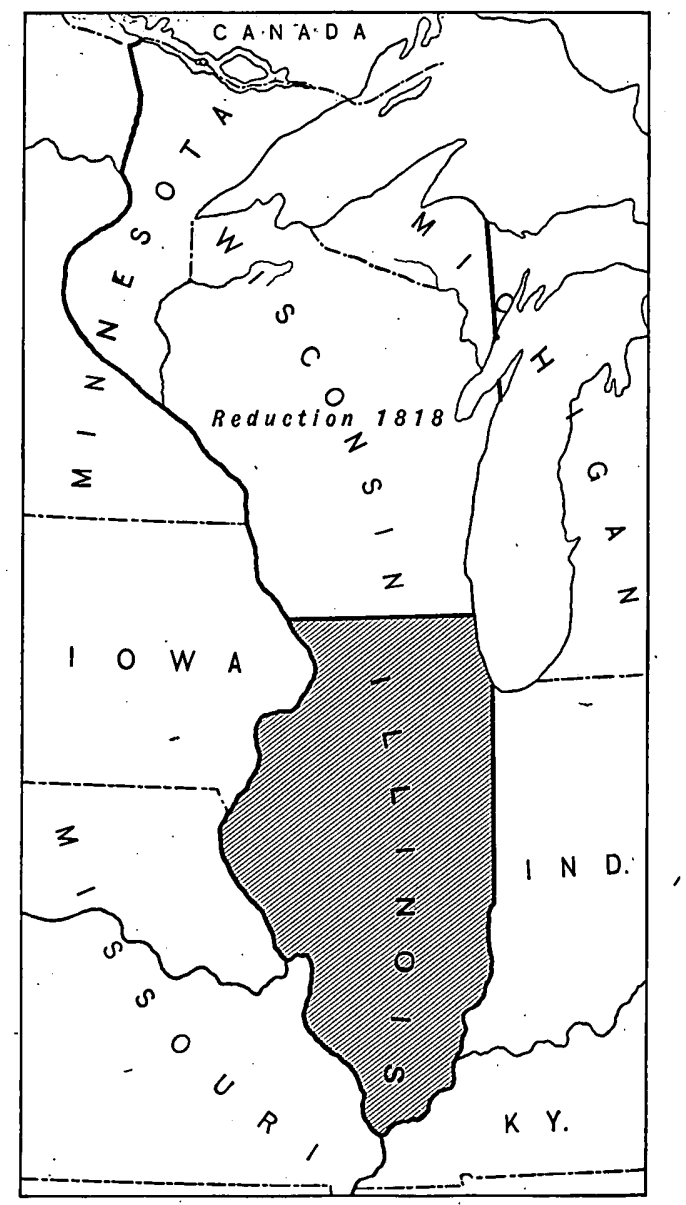

HISTORICAL DIAGRAM OF ILLINOIS. 


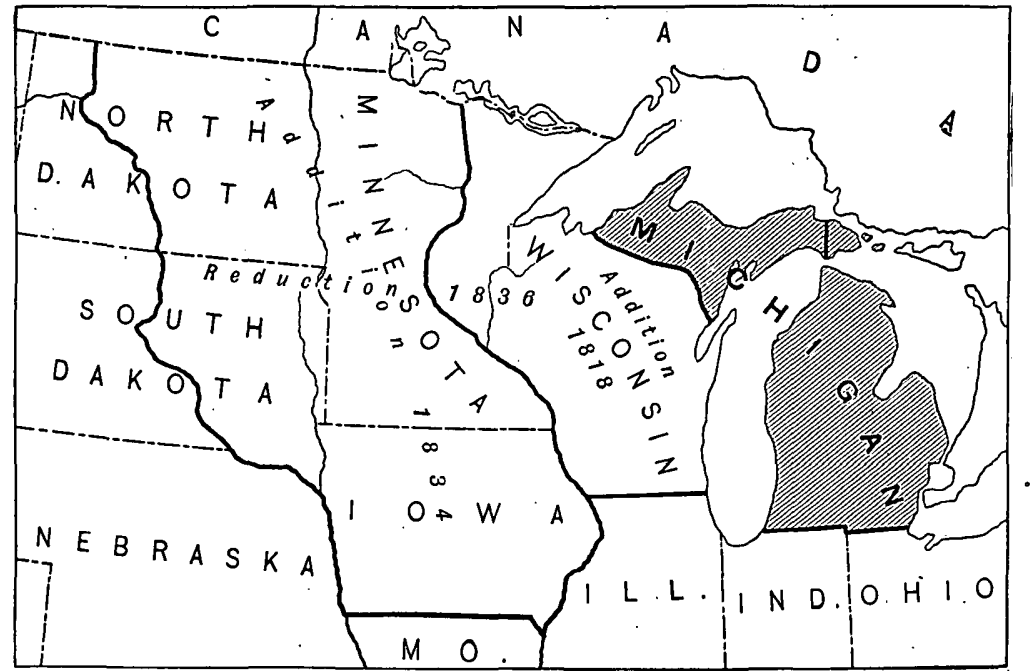

HISTORICAL DIAGRAM OF MICHIGAN.

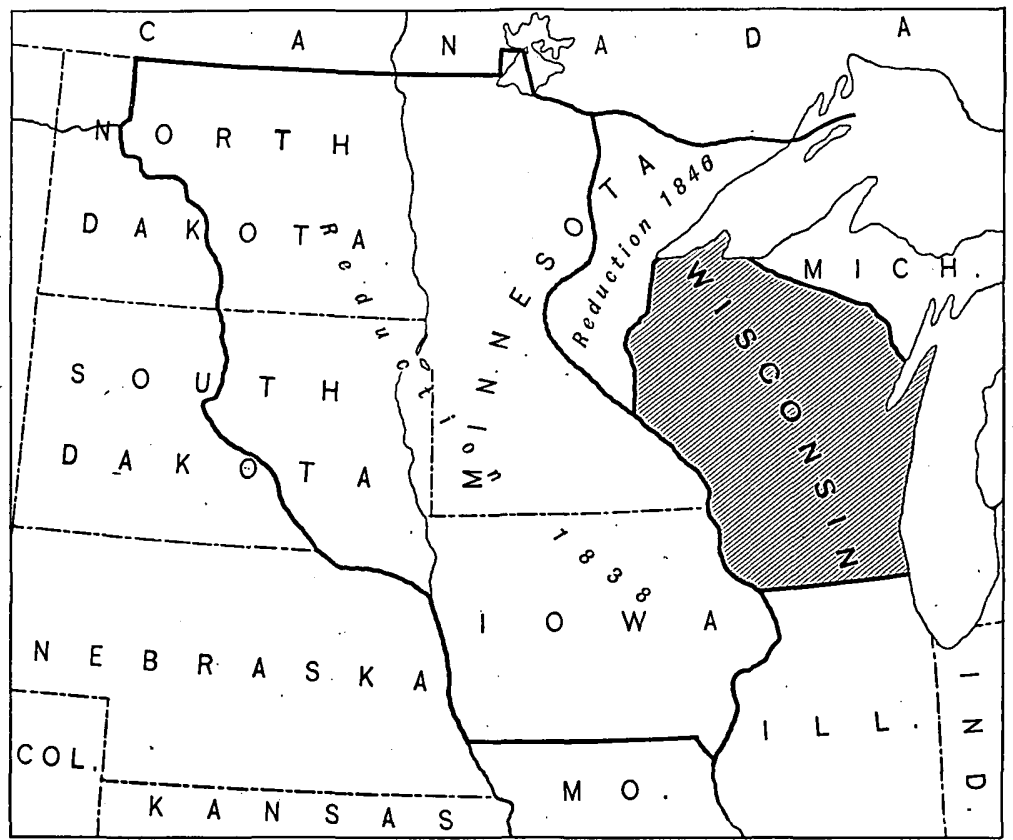

HISTORICAL DIAGRAM OF WISCONSIN. 
The enabling act for Illinois, passed in 1818, contained a provision transferring to the Territory of Michigan the portion of the Territory of Illinois not included in the State of that name. 'The following. is the text of the clause referred to:

All that part of the territory of the United States lying north of the State of Indiana, and which was included in the former Indiana Territory, together with that part of the Illinois Territory which is situated north of and not included within the boundaries prescribed by this act, to the State thereby authorized to be formed, shall be, and hereby is, attached to and made a part of the Michigan Territory, from and after the formation of the said State.

In 1834 an act was passed extending the limits of the Territory of Michigan to the Missouri River.

The clause of this act relating to area is as follows:

AN ACT to attach the territory of the United States west of the Mississippi River and north of the State of Missonri to the Territory of Michigan.

- All that part of the territory of the United States bounded on the east by the Mississippi River, on the south by the State of Missouri and a line drawn due west from the northwest corner of said State to the Missouri River; on the southwest and west by the Missouri River and the White Earth River, falling into the same; and on the north by the northern boundary of the United States, shall be, and hereby is, for the purpose of temporary government, attached to and made a part of the Territory of Michigan.

In 1836 Wisconsin Territory was formed from that part of Michigan Territory lying west of the present limits of the State of that name. (Vide Wisconsin, p. 122.)

The boundary line between Michigan and Wisconsin, between the sources of Brule and Montreal rivers, was run and marked in 1847.

Reduced to its present limits, as described in the following clause from its enabling act, Michigan was admitted to the Union January 26, 1837:

AN ACT to provide for the admission of the State of Michigan into the Union.

Beginning at the point where the above-described northern boundary of the State of Ohio intersects the eastern boundary of the State of Indiana, and running thence with the said boundary line of Ohio, as described in the first section of this act, until it intersects the boundary line between the United States and Canada in Lake Erie; thence with the said boundary line between the United States and Canada, through the Detroit River, Lake Huron, and Lake Superior, to a point where the said line last touches Lake Superior; thence in a direci line through Lake Superior to the mouth of the Montreal River; thence through the middle of the main channel of the said river Montreal to the middle of the Lake of the Desert; thence in a direct line to the nearest headwater of the Menomonee River; thence through the middle of that fork of the said river first tonched by the said line to the main channel of the said Menomonee River; thence down the center of the main channel of the same to the center of the most usual ship channel of the Green Bay of Lake Michigan; thence through the center of the most usual ship channel of the said bay to the middle of Lake Michigan; thence through the middle of Lake Michigan to the northern boundary of the State of Indiana, as that line was established by the act of Congress of the nineteenth of April, eighteen hundred and sixteen; thence due east with the

Bull. 226- $04-14$ 
north boundary line of the sair. State of Indiana to the northeast corner thereof; and thence south with the east boundary line of Indiana to the place of beginning. (Twenty-fourth Congress, first session.)

\section{The above boundaries remain unchanged.}

\section{WISCONSIN.}

Wisconsin was organized as a Territory July 3,1836 . As originally constituted its area comprised all that part of the former Territory of Michigan which lay outside of the present limits of the State of Michigan. The limits are defined in the act for its organization as follows:

Bounded on the east by a line drawn from the northeast corner of the State of Illinois, through the middle of Lake Michigan, to a point in the middle of said lake and opposite the main channel of Green Bay; and through said channel and Green Bay to the mouth of the Menomonee; thence through the middle of the main channel of said river to that head of said river nearest to the Lake of the Desert; thence in a direct line to themiddle of said lake; thence through the middle of the main channel of the Montreal River to its mouth; thence with a direct line across Lake Superior to where the territorial line of the United States last louches said lake northwest; thence on the north with the said territorial line to the White Earth River, on the west by a line from the said boundary line following down the middle of the main channel of White Earth River to the Missouri River, and down the middle of the main channel of the Missouri River to a point due west from the northwest corner of the State of Missouri, and on the south from said point due east to the northwest corner of the State of Missouri; and thence with the boundaries of the States of Missouri and Illinois as already fixed by acts of Congress. (Twenty-fourth Congress, first session.)

In 1838 all that part of the territory lying west of the Mississippi and a line drawn due north from its source to the international boundary-that is, all that part which was originally comprised in the Louisiana purchase-was organized as the Territory of Iowa. (See Iowa, p. 124.)

- On August 9, 1846, an enabling act for Wisconsin was passed giving the boundaries as follows:

Beginning at the northeast corner of the State of Illinois, that is to say, at a point in the center of Lake Michigan where the line of forty-two degrees and thirty minutes of north latitude crosses the same; thence running with the boundary line of the State of Michigan, through Lake Michigan, Green Bay, to the mouth of the Menomonee River; thence up the channel of said river to the Brule River; thence up said last-mentioned river to Lake Brule; thence along the southern shore of Lake Brule in a direct line to the center of the channel between Middle and South islands in the Lake of the Desert; thence in a direct line to the headwaters of Montreal River, as marked upon the survey made by Captain Cramm; thence down the main channel of the Montreal River to the middle of Iake Superior; thence through the center of Lake Superior to the mouth of the Saint Louis River; thence up the main channel of said river.to the first rapids in the same, above the Indian village; according to Nicollet's map; thence due south to the main branch of the river Saint Croix; thence down the middle of the main channel of said river to the Mississippi; thence down the center' of the main channel of that river to the northwest corner of the State of Illinois; thence due east with the northern boundary of the State of Illinois to the place of beginning. (Twenty-ninth Congress, first session.) 


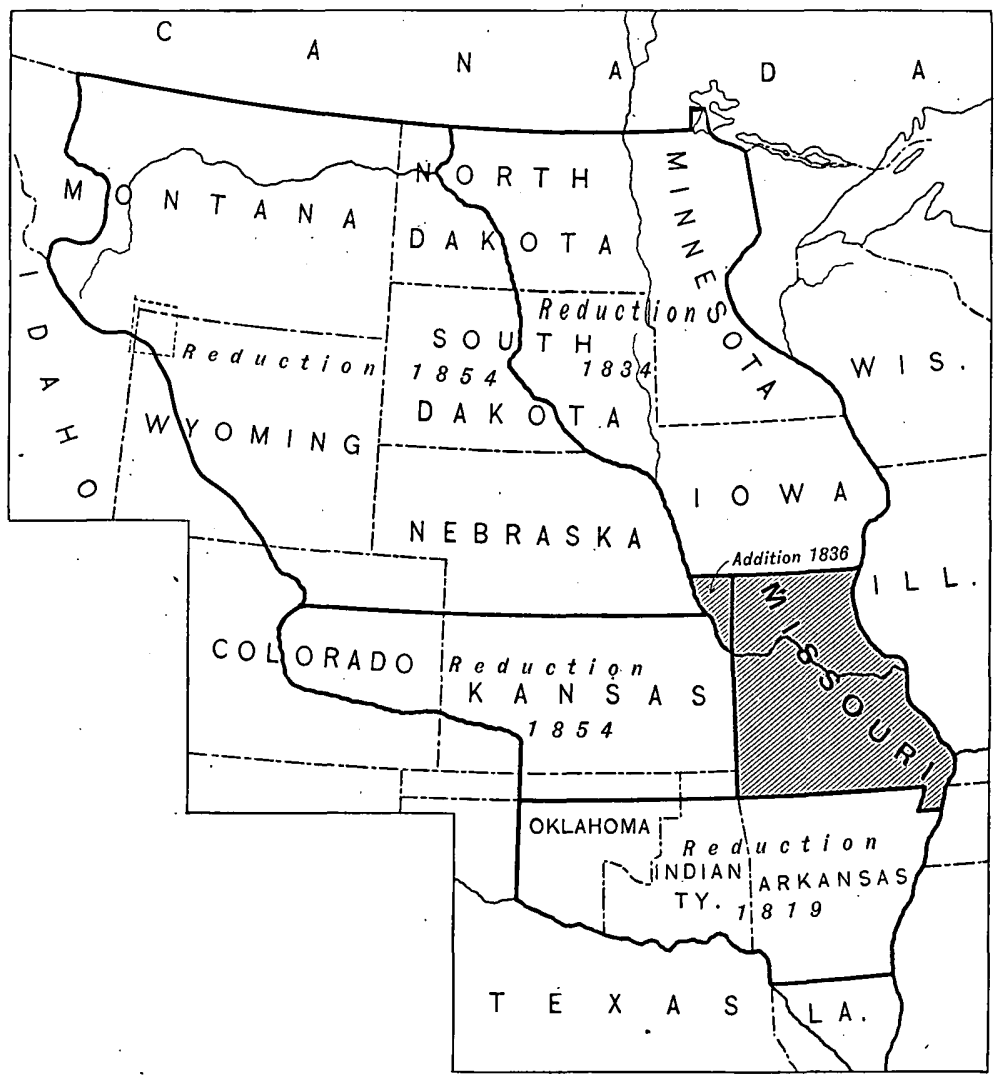

HISTORICAL DIAGRAM OF MISSOURI. 
On March 3, 1847, a supplementary act for the admission of Wisconsin was passed by Congress, in which the western boundary of the proposed State was changed as follows :

That the assent of Congress is hereby given to the change of boundary proposed in the first article of said constitution, to wit: Leaving the boundary line prescribed in the act of Congress entitled "An act to enable the people of Wisconsin Territory to form a constitution and State government, and for the admission of such State into the Union,". at the first rapids in the river St. Louis; thence in a direct line southwardly to a point fifteen miles east of the most easterly point of Lake St. Croix; thence due south to the main channel of the Mississippi River or Lake Pepin; thence down the said main channel, as prescribed in said act. (Twenty-ninth Congress, second session.)

On May. 29, 1848, Wisconsin was admitted into the Union.

The boundary between this State and Minnesota from St. Louis to .St. Croix River was surveyed and marked in 1852, under the General Land Office.

\section{MISSOURI.}

The name of the Territory of Louisiana was changed in 1812 to Missouri, by act of Congress. At that time the Territory comprised all of the original Louisiana purchase, excepting the State of Louisiana, which had been formed from it. The Territory of Arkansas, with limits very similar to those of the present State, was formed from it in 1819 . On August 10, 1821, the State of Missouri was formed and admitted, with limits, excepting as to the northwest corner, the same as at present.

\section{Boundaries are defined as follows:}

Beginning in the middle of the Mississippi River, on the parallel of thirty-six degrees of north latitude; thence west along that parallel of latitude to the Saint Francois River; thence up and following the course of that river, in the middle of the main channel thereof, to the parallel of latitude of thirty-six degrees and thirty minutes; thence west along the same to a point where the said parallel is intersected by a meridian line passing through the middle of the mouth of the Kansas River where the same empties into the Missouri River; thence from the point aforesaid north along the said meridian line to the intersection of the parallel of latitude which passes through the rapids of the river Des Moines, making the said line to correspond with the Indian boundary line; thence east from the point of intersection last aforesaid along the said parallel of latitude to the middle of the channel of the main fork of the said river Des Moines; thence down and along the middle of the main channel of the said river Des Moines to the mouth of the same where it empties into the Mississippi River; thence due east to the middle of the main channel of the Mississippi River; thence down and following the course of the Mississippi River, in the middle of the main channel thereof, to the place of beginning. (Sixteenth Congress, first session.)

In 1836 the boundaries were extended on the northwest to the Missouri River, as described in the following act of the legislature amendatory to the.constitution of 1820 :

That the boundary of the State be so altered aud extended as to include all that tract of land lying on the north side of the. Missouri River and west of the present boundary of this State, so that the same shall be bounded on the south by the middle 
of the main channel of the Missouri River and on the north by the present northern boundary line of the State, as established by the constitution, when the same is continued in a right line to the west, or to include so much of said tract of land as Congress may assent.

This was ratified by Congress in the following act:

AN ACT to extend the western boundary of the State of Missouri to the Missouri River.

That when the Indian title to all the lands lying between the State of Missouri and the Missouri River shall be extinguished, the jurisdiction over said lands shall be hereby ceded to the State of Missouri, and the western boundary of said State shall be then extended to the Missouri River. (Twenty-fourth Congress, first session.)

The north boundary of Missouri was surveyed and marked in part in 1816, and the remainder in 1850, under the General Land Office.

The western boundary was run and marked, from the mouth of Kansas River to the southwestern corner of the State, in 1823.

The territory remaining after the formation of the State bore the name of Missouri for many years thereafter. Meanwhile, however, it was reduced by the formation of several Territories which were carved from its area. In 1834 the part north of the State of Missouri and east of Missouri and White Earth rivers was annexed to the Territory of Michigan. (For further history of this portion, vide Michigan, p. 120; Iowa, below; Minnesota, p. 125; and Dakota, p. 129.) In 1854 Kansas and Nebraska Territories were formed, absorbing the remainder. (Vide Kansas, p. 126, and Nebraska, p. 127.)

The following are the boundaries of Missouri as at present established: The east boundary is the mid-channel of the Mississippi River from the mouth of the Des Moines to its point of intersection with the thirty-sixth parallel of latitude; the south boundary begins at the latter point and runs west on the parallel of 36 degrees of latitude to the Saint Francis River, thence up the mid-channel of that river to the parallel of latitude $39^{\circ} 30^{\prime}$, thence west on that parallel to its intersection by a meridian passing through the middle of the mouth of the Kansas River; the west boundary is the last-mentioned meridian as far north as the mouth of the Kansas River, thence it follows northwestward the mid-channel of the Missouri River to the parallel of latitude passing through the rapids of Des Moines River, which is approximately the parallel of $40^{\circ} 35^{\prime}$; the north boundary is the lastmentioned parallel as far east as its point of intersection with the Des Moines River, whence it follows the mid-channel of the Des Moines River southward to its mouth.

\section{IOWA.}

Iowa was organized as a Territory on July 3, 1838, being formed from a portion of $W$ isconsin Territory. The limits were defined as -follows in the act creating it:

All that part of the present Territory of Wisconsin which lies west of the Mississippi River and west of the line drawn due north from the headwaters or sources of the Mississippi to the Territorial line. (Twenty-fifth Congress, second session. See Wisconsin, p. 122.) 
U. S. GEOLOGICAL SURVEY

BULLETIN NO. 226 PL. XLVIII

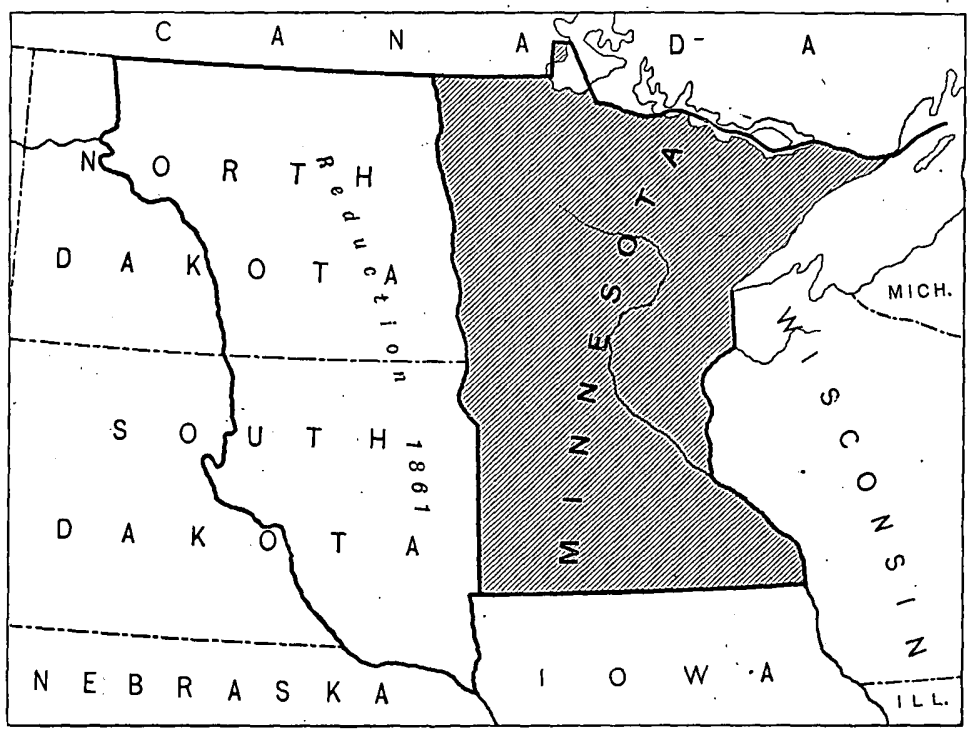

HISTORICAL DIAGRAM OF MINNESOTA

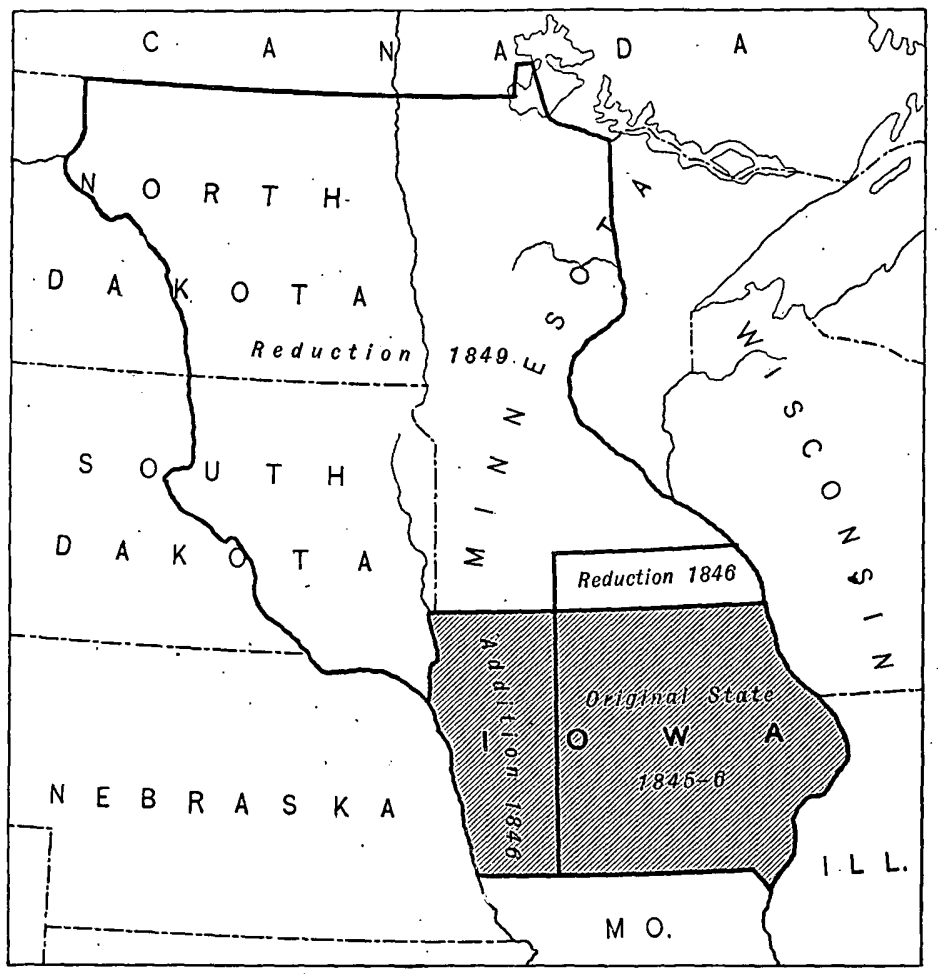

HISTORICAL DIAGRAM OF IOWA. 
The following clause from an act passed in 1839 is supplementary to the above act:

AN ACT to define and establish the eastern boundary line of the Territory of Jowa.

That the middle or center of the main channel of the river Mississippi shall be deemed, and is hereby declared, to be the eastern boundary line of the Territory of Iowa, so far or to such extent as the said Territory is bounded eastwardly by or upon saicl river. (Twenty-fifth Congress, third session.)

Iowa was admitted to the Union on March 3, 1845. As originally constituted the limits of the State were quite different from those which it has at present.

The following extract from the enabling act gives the original limits:

That the following shall be the boundaries of the said State of Iowa, to wit: Beginning at the mouth of the Des Moines River at the middle of the Mississippi; thence by the middle of the channel of that river to a parallel of latitude passing through. the mouth of the Mankato or Blue Earth River; thence west along the said parallel of latitude to a point where it is intersected by a meridian line, seventeen degrees and thirty minutes west of the meridian of Washington City; thence due south to the northern boundary line of the State of Missouri; thence eastwardly following that boundary to the point at which the same intersects the Des Moines River; thence by the middle of the channel of that river to the place of beginining. (Twenty-eighth Congress, second session.)

On December 2S, 1846, an act was passed changing the boundaries of the State and giving it its present limits.

The following extract from the act defines the boundaries as at present constituted:

Beginning in the middle of the main channel of the Mississippi River at a point due east of the middle of the mouth of the main channel of the Des Moines River; thence up the middle of the main channel of the said Des Moines River to a point on said river where the northern boundary line of the State of Missouri, as established by the constitution of that State, adopted June twelfth, eighteen hundred and twenty, crosses the said middle of the main channel of the said Des Moines River; thence westwardly along the said northern boundary line of the State of Missouri, as established at the time aforesaid, until an extension of said line intersect the middle of the main channel of the Missouri River, to a point opposite the middle of the main channel of the Big Sioux River, according to Nicollet's map; thence up the main channel of the said Big Sioux River, according to said map, until it is intersected by the parallel of forty-three degrees and thirty minutes north latitude; thence east along said parallel of forty-three degrees and thirty minutes, until said paraliel intersect the middle of the main channel of the Mississippi River; thence down the middle of the main channel of said Mississippi River to the place of beginning.

Its northern boundary was surveyed and marked in 1852, under the General Land Office.

\section{MINNESOTA.}

The Territory of Minnesota was organized on March 3, 1849, and originally comprised the portion of the former Territory of Iowa, outside of the limits of the present State of Iowa, extending east to the 
west boundary line of Wisconsin. The terms of the act creating this Territory, so far as they relate to its boundary, are as follows:

All that part of the territory of the United States which lies within the following limits, to wit: Beginning in the Mississippi River, at the point where the line of forty-three degrees and thirty minutes of north latitude crosses the same; thence running due west on said line, which is the northern boundary of the State of Iowa; to the northwest corner of the said State of Iowa; thence southerly along the western boundary of said State to the point where said boundary strikes the Missouri River; thence up the middle of the main channel of the Missouri River to the mouth of the White Earth River; thence up the middle of the main channel of the White Earth River to the boundary line between the possessions of the United States and Great Britain to Lake Superior; thence along the western boundary line of said State of Wisconsin to the Mississippi River; thence down the main channel of said river to the place of beginning. (Thirtieth Congress, second session.)

Minnesota was admitted as a State on May 11, 1858, with the same boundaries which it has at present. These are given in the enabling act as follows: .

Beginning at the point in the center of the main channel of the Red River of the North where the boundary line between the United States and the British Possessions crosses the same; thence up the main channel of said river to that of the Bois des Sioux River; thence.up the main channel of said river to Lake Traverse; thence up the center of said lake to the southern extremity thereof; thence in a direct line to the head of Big Stone Lake; thence through its center to its outlet; thence by a due south line to the north line of the State of Iowa; thence east along the northern boundary of said State to the main channel of the Mississippi River; thence up the main channel of said river and following the boundary line of the State of Wisconsin until the same intersects the Saint Louis River; thence down said river to and through Lake Superior, on the boundary line of Wisconsin and Michigan, until it intersects the dividing line between the United States and the British Possessions; thence up Pigeon River, and following said dividing line, to the place of beginning.

The western boundary line, from Big Sioux River to Minnesota River, was surveyed and marked in 1859-60, under the General Land Office.

KANSAS.

The Territory of Kansas was organized on May 30, 1854, from a part of Missouri Territory. The following clause from the act of organization defines its limits:

Secrion 19. All that part of the territory of the United States included within the following limits, except such portions thereof as are hereinafter expressly exempted from the operations of this act, to wit: Beginning at a point on the western boundary of the State of Missouri, where the thirty-seventh parallel of north latitude crosses the same; thence west on said parallel to the eastern boundary of New Mexico; thence north on said boundary to latitude thirty-eight; thence following said boundary westward to the east boundary of the Territory of Utah, on the summit of the Rocky Mountains; thence northward on said summit to the fortieth parallel of latitude; thence east on said parallel to the western boundary of the State of Missouri; thence south with the western boundary of said State to the place of beginning, be, and the same is hereby, created into a temporary government by the name of the Territory of Kansas. 
U. S. GEOLOGICAL SURVEY

BULLETIN NO. 226 PL. XLIX

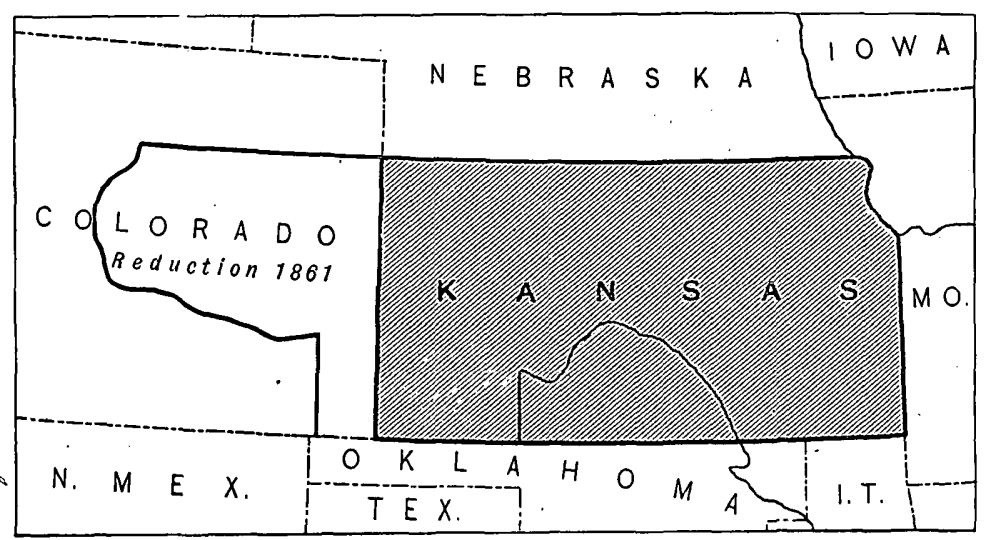

HISTORICAL DIAGRAM OF KANSAS.

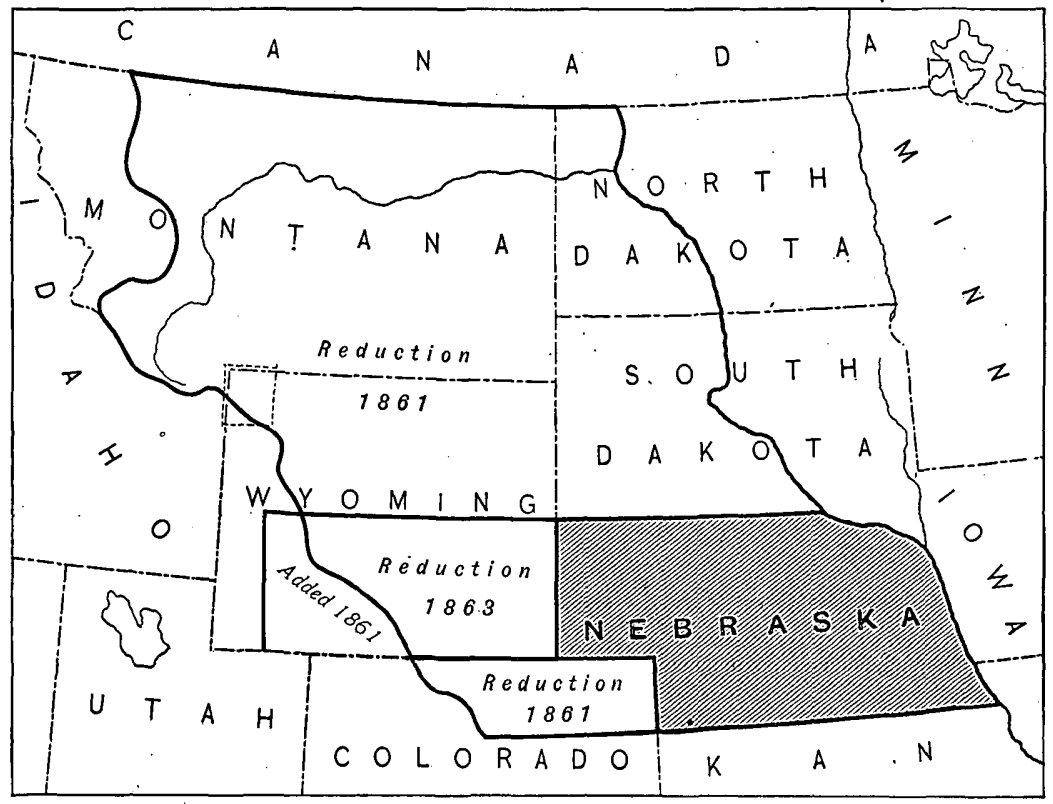

HISTORICAL DIAGRAM OF NEBRASKA. 
A portion of this Territory was given up to Colorado at the time of its formation in 1861 . (Vide Colorado, p. 132.)

Kansas was admitted into the Union on January 29,1861 , with its present boundaries, which are thus defined in the enabling act:

The said State shall consist of all the territory included within the following boundaries, to wit: Beginning at a point on the western boundary of the State of Missouri where the thirty-seventh parallel of north latitude crosses the same; thence west on said parallel to the twenty-fifth meridian of longitude west from Washington; thence north on said meridian to the fortieth parallel of latitude; thence east on said parallel to the western boundary of the State of Missouri; thence south with the western boundary of said State to the place of beginning.

The south boundary was surveyed and marked by Col. J. E. Johnston, in 1857. This line was subsequently retraced and re-marked by deputy surveyors, in the extension of the public land surveys. The western boundary was surveyed in 1872, under the General Land Office.

The north boundary, which is the base line for the sixth principal meridian, was run by deputy surveyors of the General Land Office, 1855-1859, the initial point, on the Missouri river, having been determined by Capt. Lee, U. S. topographical engineer.

\section{NEBRASKA.}

The Territory of Nebraska was formed on May 30, 1854, from the northwestern part of Missouri Territory. Its limits, as originally constituted, are defined as follows in the act of organization:

Beginning at a point in the Missouri River where the fortieth parallel of north latitude crosses the same; thence west on said parallel to the east boundary of the Territory of Utah, on the summit of the Rocky Mountains; thence on said summit northward to the forty-ninth parallel of north latitude; thence east on said parallel to the western boundary of the Territory of Minnesota; thence southward on said boundary to the Missouri River; thence down the main channel of said river to the place of beginning, be, and the same is hereby, created into a temporary government by the name of the Territory of Nebraska. (Thirty-third Congress, first session.)

This area was reduced in 1861 by the formation of the Territories of Colorado and Dakota. (Vide Colorado, p. 132, and Dakota, p. 129.)

In 1861 ; in the act creating the. Territory of Dakota, a small area was added to the western end of Nebraska. The following is the text of the act making this addition:

That, until Congress shall otherwise direct; that portion of the Territories of Utah and Washington between the forty-first and forty-third degrees of north latitude, and east of the thirty-third meridian of longitude west from Washington, shall be, and is hereby, incorporated into and made a part of the Territory of Nebraska.

The State of Nebraska was admitted on March 1, 1867.

Its limits are defined as follows in the enabling act:

That the said State of Nebraska shall consist of all the territory included within the following boundaries, to wit: Commencing at a point formed by the intersection 
of the western boundary of the State of Missouri with the fortieth degree of north latitude; extending thence due west along said fortieth degree of north latitude to a point formed by its intersection with the twenty-fifth degree of longitude west from Washington; thence north along said twenty-fifth degree of longitude to a point formed by its intersection with the forty-first degree of north latitude; thence west along said forty-first degree of north latitude to a point formed by its intersection with the twenty-seventh degree of longitude. west from Washington; thence north along said twenty-seventh degree of west longitude to a point formed by its intersection with the forty-third degree of north latitude; thence east along said forty-third degree of north latitude to the Keyapaha River; thence down the middle of the channel of said river, with its meanderings, to its junction with the Niobrara River; thence down the middle of the channel of said Niobrara River, and following the meanderings thereof, to its junction with the Missouri River; thence down the midclle of the channel of said Missouri River, and following the meanderings thereof, to the place of beginning. (Thirty-eighth Congress, first session.)

In 1870 an act was passed to redefine a portion of the boundary between Nebraska and the Territory of Dakota, the pertinent portion of which is as follows:

That so soon as the State of Nebraska, through her legislature, has given her consent thereto, the center of the main channel of the Missouri River shall be the boundary line between the State of Nebraska and Territory of Dakota, between the following. points, to wit: Commencing at a point in the center of said main channel, north of the west line of section twenty-four in township twenty-nine north, of range eight east of the sixth principal meridian, and running along the same to a point west of the most northerly portion of fractional section seventeen, of township twenty-nine north, of range nine east of said meridian, in the State of Nebraska, as meandered and shown by the plats and surveys of said sections originally made and now on file in the General Land Office. (Forty-first Congress, second session.)

The west boundary on the twenty-fifth degree of longitude west of Washington, between latitudes $40^{\circ}$ and $=41^{\circ}$, the south boundary on the forty-first parallel from the twenty-fifth degree of longitude to the twenty-seventh degree, and the west boundaly on the twenty-seventh degree of longitude, between the forty-first degree and the forty-third degree, were surveyed and marked in 1869, under the General Land Office.

In 1882 an act was passed transferring to this State from Dakota a small area lying between the Keyapaha River and the forty-third parallel of latitude. The following is the act in question:

Be it enacted, *** That the northern boundary of the State of Nebraska shall be, and hereby is, subject to the provisions hereinafter contained, extended so as to include all that portion of the Territory of Dakota lying south of the forty-third parallel of north latitude and east of the Keyapaha River and west of the main channel of the Missouri River. (Forty-seventh Congress, first session.)

The north boundary, from the Keyapaha River westward, was surreyed in 1873. In 1893 the part of this boundary east of Keyapaha River was surveyed and the remainder resurveyed. All this was done under the General Land Office. 


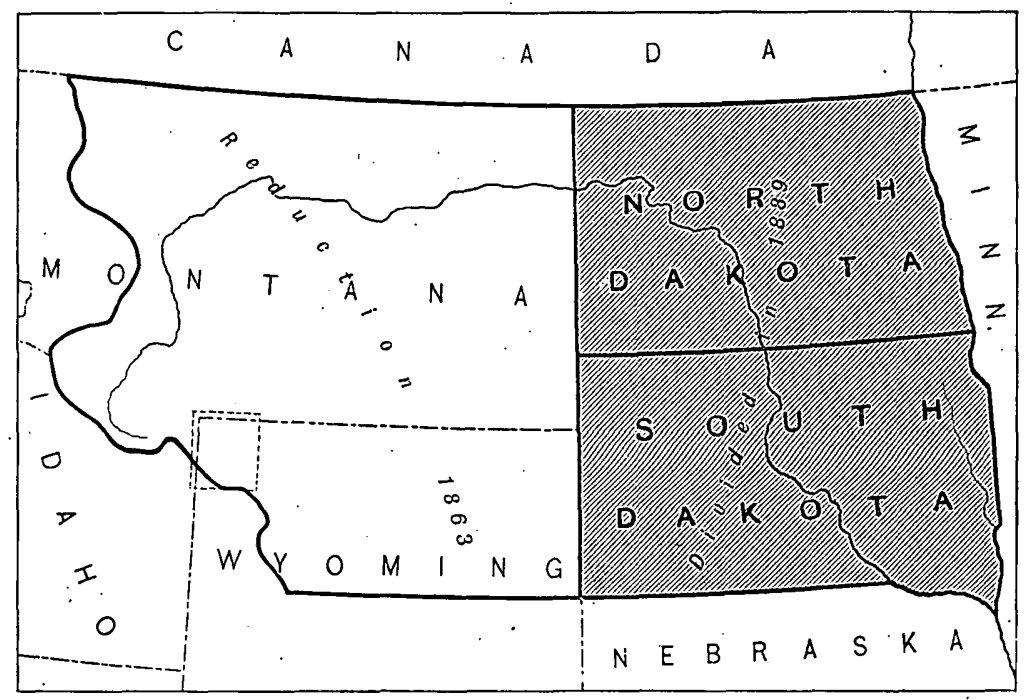

HISTORICAL DIAGRAM OF NORTH DAKOTA AND SOUTH DAKOTA.

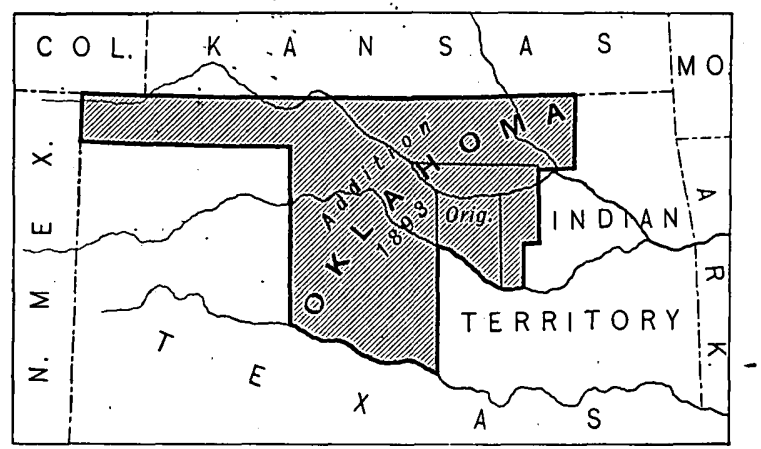

HISTORICAL DIAGRAM ÓF OKLAHOMA. 


\section{NORTH DAKOTA AND SOUTH DAKOTA.}

The Territory of Dakota was organized on March 2,1861, from parts of Minnesota and Nebraska Territories. The following from the act of organization defines its original limits:

All that part of the territory of the United States included within the following limits, namely: Commencing at a point in the main channel of the Red River of the North where the forty-ninth degree of north latitude crosses the same; thence up the main channel of the same and along the boundary of the State of Minnesota to Big Stone Lake; thence along the boundary line of the said State of Minnesota to the Iowa line; thence along the boundary line of the State of Iowa to the point of intersection between the Big Sioux and Missouri rivers; thence up the Missouri River and along the boundary line of the Territory of Nebraska to the mouth of the Niobrara or Rumning Water River; thence following up the same, in the middle of the main channel thereof, to the mouth of the Keyapaha or Turtle Hill River; thence up said river to the forty-third parallel of north latitude; thence due west to the present boundary of the Territory of Washington; thence along the boundary line of Washington Territory to the forty-ninth degree of north latitude; thence east along said forty-ninth degree of north latitude to the place of beginning, be, and the same is hereby, organized into a temporary government by the name of the Territory of Dakota. (Thirty-sixth Congress, second session.)

In 1863 the Territory of Idaho was formed, its area having been taken from Washington, Dakota, and Nebraska. (Vide Idaho; p. 136.)

In 1864, in the act creating Montana Territory, the area described in the following" paragraph was temporarily restored to the jurisdiction of Dakota:

That, until Congress shall otherwise direct, all that part of the Territory of Idaho included within the following boundaries, to wit: Commencing at a point formed by tho intersection of the thirty-third degree of longitude west from Washington with the forty-first degree of north latitude; thence along said thirty-third degree of longitude to the crest of the Rocky Mountains; thence northward along the said crest of the Rocky Mountains to its intersection with the forty-fourth degree and thirty minutes of north latitude; thence eastward along said forty-fourth degree thirty minutes north latitude to the thirty-fourth degree of longitude west from Washington; thence northward along said thirty-fourth degree of longitude to its intersection with the forty-fifth. degree north latitude; thence eastward along said forty-fifth degree of north latitude to its intersection with the twenty-seventh degree of longitude west from Washington; thence south along said twenty-seventh degree of longitude west from Washington to the forty-first degree north latitude; thence west along said forty-first degree of latitude to the place of beginning; shall be, and is hereby, incorporated temporarily into and made part of the Territory of Dakota.

In 1882 a small area was transferred to Nebraska. (Vide Nebraska, p. 127.)

In 1877 that part of the west boundary between latitudes $43^{\circ}$ and $45^{\circ}$ was surveyed and marked, under the General Land Office.

On November 2, 1889, the Territory of Dakota was divided into North and South Dakota, and each was admitted as a State. The following extract from the enabling act defines the boundary between these States:

The area comprising the Territory of Dakota shall *** be divided on the line of the seventh standard parallel produced due west to the western boundary of said Territory.

Bull. 226-04-15 
The boundary line between the two States was surveyed in 1891-92, under the General Land Office.

\section{OKLAHOMA.}

The Territory of Oklahoma was organized under an act passed May 2,1890 , from the western part of the Indian Territory, Its limits as originally constituted were as is set forth in the following act:

Be it enacted by the Senate and House of Representatives of the United States of America in Congress assembled, SEc. 1. That all that portion of the United States now known as the Indian Territory, except so much of the same as is actually occupied by the Five Civilized Tribes, and the Indian tribes within the Quapaw Indian Agency, and except the unoccupied part of the Cherokee Outlet, together with that portion of the United States known as the Public Land Strip, is hereby erected into a temporary government by the name of the Territory of Oklahoma. The portion of the Indian Territory included in said Territory of Oklahoma is bounded by a line drawn as follows: Commencing at a point where the ninety-eighth meridian crosses the Red River; thence by said meridian to the point where it crosses the Canadian River; thence along said river to the west line of the Seminole country; thence along said line to the north fork of the Canadian River; thence down said river to the west line of the Creek country; thence along said line to the northwest corner of the Creek country; thence along the north line of the Creek country to the ninety-sixth meridian; thence northward by said meridian to the southern boundary line of Kansas; thence west along said line to the Arkansas River; thence down said river to the north line of the land occupied by the Ponca tribe of Indians, from which point the line runs so as to include all the lands occupied by the Ponca, Tonkawa, Otoe and Missouria, and the Pawnee tribes of Indians until it strikes the south line of the Cherokee Outlet, which it follows westward to the east line of the State of Texas; thence by the boundary line of the State of Texas to the point of beginning. The Public Land Strip which is included in said Territory of Oklahoma is bounded east by the one hundredth meridian, south by Texas, west by New Mexico, north by Colorado and Kansas. Whenever the interest of the Cherokee Indians in the land known as the Cherokee Outlet shall have been extinguished and the President shall make proclamation thereof, said outlet shall thereupon and without further legislation become a part of the Territory of Oklahoma. Any other lands, within the Indian Territory not embraced within these boundaries shall hereafter become a part of the Territory of Oklahoma whenever the Indian nation or tribe owning such lands shall signify to the President of the United States in legal manner its assent that such lands shall so become a part of said Territory of Oklahoma, and the President shall thereupon make proclamation to that effect.

The lands embraced within the limits above set forth comprised the present Territory of Oklahoma, with the exception of an area on the north known as the Cherokee Strip, and provision was made for its incorporation, without additional legislation, within the Territory whenever the Indian title to it should be extinguished. This was done and the strip was added to the Territory by proclamation of the President, issued in September, 1893, giving Oklahoma its present limits. These differ from those above set forth only in a part of the northern boundary, which now corresponds with the south boundary of Kansas from the ninety-sixth meridian west. 
MONTANA.

The Territory of Montana was organized May 26, 1864, from a portion of Idaho. Its limits, which have been changed but slightly, are given in the following extract from the organizing act:

That all that part of the territory of the United States included within the limits, to wit: Commencing at a point formed by the intersection of the twenty-seventh degree of longitude west from Washington with the forty-fifth degree of north latitude; thence due west on said forty-fifth degree of latitude to a point formed by its intersection with the thirty-fourth degree of longitude west from Washington; thence due south along said thirty-fourth degree of longitude to its intersection with the forty-fourth degree and thirty minutes of north latitude; thence due west along said forty-fourth degree and thirty minutes of north latitude to a point formed by its intersection with the crest of the Rocky Mountains; thence following the crest of the Rocky Mountains north ward till its intersection with the Bitter Root Mountains; thence northward along the crest of said Bitter Root Mountains to its intersection with the thirty-ninth degree of longitude west from Washington; thence along said thirty-ninth degree of longitude northward to the boundary line of the British possessions; thence eastward along said boundary line to the twenty-seventh degree of longitude west from Washington; thence southward along said twenty-seventh degree of longitude to the place of beginning, be, and the same is hereby, created into a temporary government by the name of theTerritory of Montana. (Thirty-eighth Congress, first session.)

In 1873 Congress, under the erroneous impression that a portion of Dakota remained west of Wyoming, and adjoining Montana, passed an act to attach it to Montana. As, however, no such detached area could by any possibility have existed, the compilers of the Revised Statutes sought to give the act effect by shifting a portion of the southern boundary of Montana from the parallel of $44^{\circ} 30^{\prime}$ to the continental watershed, thereby reducing Montana's area. The following is the act referred to:

AN ACT to readjust the western boundary of Dakota Territory.

That all that portion of Dakota Territory lying west of the one hundred and eleventh meridian of longitude which, by an erroneous definition of the boundaries of said Territory by a former act of Congress, remains detached and distant from Dakota proper some two hundred miles, be, and the same is hereby, attached to the adjoining territory of Montana. (Forty-second Congress, third session.)

The boundaries of Montana are as follows: Beginning at the intersection of the twenty-seventh meridian of longitude with the boundary line between the United States and the British possessions, it follows said meridian south to the forty-fifth parallel of latitude, thence west on this parallel to the thirty-fourth meridian, south on the thirty-fourth meridian to the point where that meridian intersects the continental watershed, thence westward and northwestward, following the line of the continental watershed and the summit of the Bitter Root range, to its intersection with the thirty-ninth meridian; thence north on the thirty-ninth meridian to the boundary line between the United States 
and British possessions and east on that boundary line to the point of beginning.

The east boundary of Montana was surveyed and marked in 1885 , and the south boundary in 1879-80, under the General Land Office. That portion of the west boundary between the crest of the Bitter Root Mountains and the Canada line was surveyed and marked in 1898-99, under the United States Geological Survey.

Montana was admitted as a State on November 8, 1889, with the above boundaries.

\section{WYOMING.}

Wyoming was organized as a Territory on July 25, 1868, from an area previously comprised in the Territories of Dakota, Idaho, and Utah. Its limits, which are the same as originally constituted, are defined in the following clause from the act creating the Territory:

That all that part of the United States described as follows: Commencing at the intersection of the twenty-seventh meridian of longitude west from Washington with the forty-fifth degree of north latitude, and running thence west to the thirtyfourth meridian of west longitude, thence south to the forty-first degree of north latitude, thence east to the twenty-seventh meridian of west longitude, and thence north to the place of beginning, be, and the same is hereby, organized into a temporary government by the name of the Territory of Wyoming. (Fortieth Congress, second session.)

Wyoming was admitted as a State on July 10, 1890, with the above boundaries.

The south and west boundaries were surveyed and marked in 1873, under the General Land Office.

\section{COLORADO.}

Colorado was organized as a Territory on February 28, 1861, with the limits which it has at present, being made from portions of Utah, New Mexico, Kansas, and Nebraska.

On August 1, 1876, it was admitted as a State.

The following clause from the enabling act gives its limits:

AN ACT to enable the people of Colorado to form a constitution and State government, and for the admission of such State into the Union on an equal footing with the original States.

SEc. 2. That the said State of Colorado shall consist of all the territory included within the following boundaries, to wit: Commencing at a point formed by the intersection of the thirty-seventh degree of north latitude with the twenty-fifth degree of longitude west from Washington; extending thence due west along said thirtyseventh degree of north latitude to a point formed by its intersection with the thirtysecond degree of longitude west from Washington; thence due north along said thirty-second degree of west longitude to a point formed by its intersection with the forty-first degree of north latitude; thence due east along said forty-first degree of north latitude to a point formed by its intersection with the twenty-fifth degree of longitude west from Washington; thence due south along said twenty-fifth degree of west longitude. (Thirty-eighth Congress, first session.) 


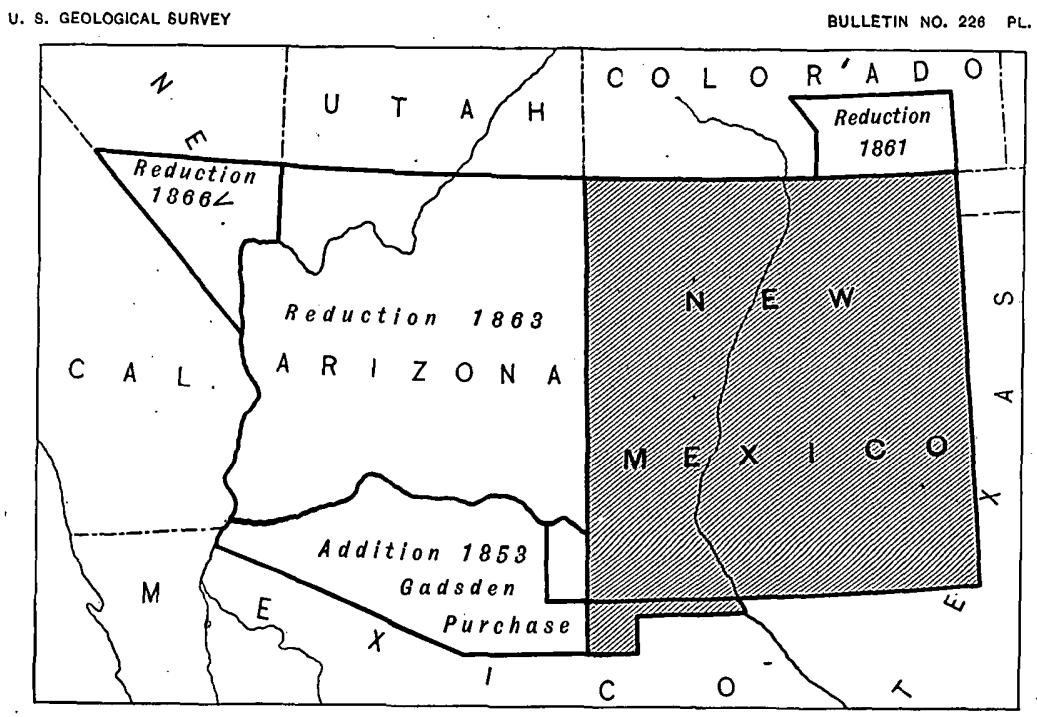

HISTORICAL DIAGRAM OF NEW MEXICO.

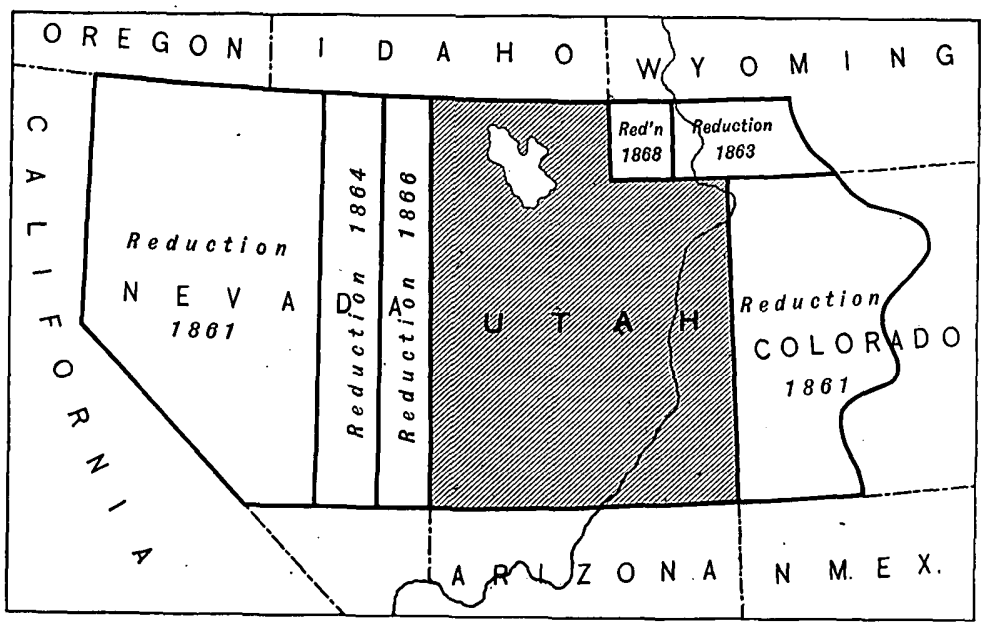

HISTORICAL DIAGRAM OF UTAH. 
The south boundary of Colorado was run and marked in 1868 and 1874, and the west boundary in 1878-79. The latter line was retraced and re-marked in 1885. All this was under the General Land Office.

\section{NEW MEXICO.}

New Mexico was organized as a Territory on December 13, 1850. Its original area formed a part of the region transferred by Mexico to the United States by the treaty of Guadalupe-Hidalgo and by Texas. It was subsequently enlarged by the Gadsden Purchase. The formation of Colorado Territory in 1861 and of Arizona in 1863 reduced its area to its present limits. (Vide Colorado, p. 132, and Arizona, p. 134.)

The following clause from the act creating the Territory gives its original limits:

Secrion 2. And be it further enacted, That all that portion of the territory of the United States bounded as follows: Beginning at a point in the Colorado River, where the boundary line with the Republic of Mexico crosses the same; thence eastwardly with the said boundary line to the Rio Grande; thence following the main channel of said river to the parallel of the thirty-second degree of north latitucle; thence east with said degree to its intersection with the one hundred and third degree of longitude west of Greenwich; thence north with said degree of longitude to the parallel of thirty-eighth degree of north latitude; thence west with said parallel to the summit of the Sierra Madre; thence south with the crest of said mountains to the thirtyseventh parallel of north latitude; thence west with said parallel to its intersection with the boundary line of the State of California; thence with said boundary line to the place of beginning-be, and the same is hereby, erected into a temporary government by the name of the Territory of New Mexico. (Thirty-first Congress, first session.)

The present boundaries of New Mexico are as follows: Beginning at the point of intersection of the one hundred and third meridian of longitude west of Greenwich with the thirty-seventh parallel of latitude; running thence south to its point of intersection with the thirty-second . parallel of latitude; thence west on this parallel to its intersection with the Rio Grande; thence southerly down the main channel of the Rio Grande to its point of intersection with the boundary line between the United States and Mexico; thence with this boundary to its intersection with the thirty-second meridian of longitude; thence north along this meridian to the thirty-seventh parallel of latitude, and so along that parallel to the point of beginning.

The west boundary of New Mexico was run and marked in 1875, under the General Land Office.

UTAH.

Ctah was organized on September 9, 1850, from territory acquired from Mexico by the treaty of Guadalupe-Hidalgo. Its limits originally extended from the eastern boundary of California to the Rocky 
Mountains, and from the thirty-seventh to the forty-second parallel. This area was reduced by the formation, in 1861, of the Territories of Nevada (vide p. 135) and Colorado (see p. 132, and in 1864 and 1866 by the extension eastward of the limits of the State of Nevada.

The following is an extract from the act creating the Territory:

All that part of the territory of the United States included within the following limits, to wit: Bounded on the west by the State of California, on the north by the Territory of Oregon, and on the east by the summit of the Rocky Mountains, and on the south by the thirty-seventh parallel of north latitude, be, and the same is hereby, created into a temporary government, by the name of the Territory of Utah.

The present boundaries of Utah are as follows: Commencing with the intersection of the forty-second parallel of latitude with the thirtyfourth meridian of longitude; running thence south on this meridian to the forty-first parallel of latitude; thence east on this parallel to the thirty-second meridian of longitute; thence south on this meridian to its intersection with the thirty-seventh parallel of latitude; thence west upon this parallel of latitude to its intersection with the thirtyseventh meridian of longitude; thence north on this meridian to its intersection with the forty-seventh parallel of latitude; thence east on the forty-seventh parallel of latitude to the point of beginning.

Utah was admitted as a State on January 4, 1896, with the abore boundaries.

Its north boundary, from longitude $34^{\circ}$ to $37^{\circ}$, was surveyed and marked in 1871, and its west boundary in 1870 , under the General Land Office.

ARIZONA.

Arizona was organized as a Territory on February 24,1863 . Its area was formerly comprised in the Territory of New Mexico. In 1866 a portion of it was cut off and given to the State of Nevada. (Vide Nevada, p. 135.) The following clause from the act creating it gives its limits as originally constituted:

That all that part of the present Territory of New Mexico situate west of the line running due south from the point where the southwest corner of the Territory of Colorado joins the northern boundary of the Territory of New Mexico to the southern boundary line of said Territory of New Mexico be, and the same is hereby, erected into a temporary government by the name of the Territory of Arizona. (For limits of the piece cut off and added to Nevada, see that State.)

The present boundaries of Arizona are as follows: Beginning at the point of intersection of the thirty-seventh parallel of latitude with the thirty-second meridian of longitude; thence south along this meridian to its intersection with the boundary line between the United States and Mexico; thence with this boundary to the Colorado River; thence up the middle of the main channel of the Colorado River to its point of intersection with the thirty-seventh meridian of longitude; north 


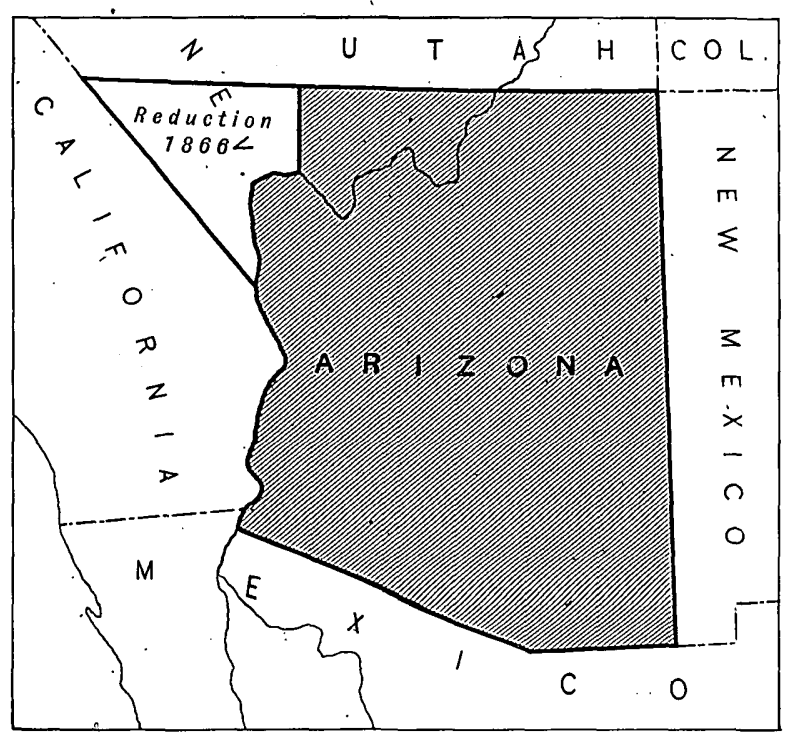

HISTORICAL DIAGRAM OF ARIZONA.

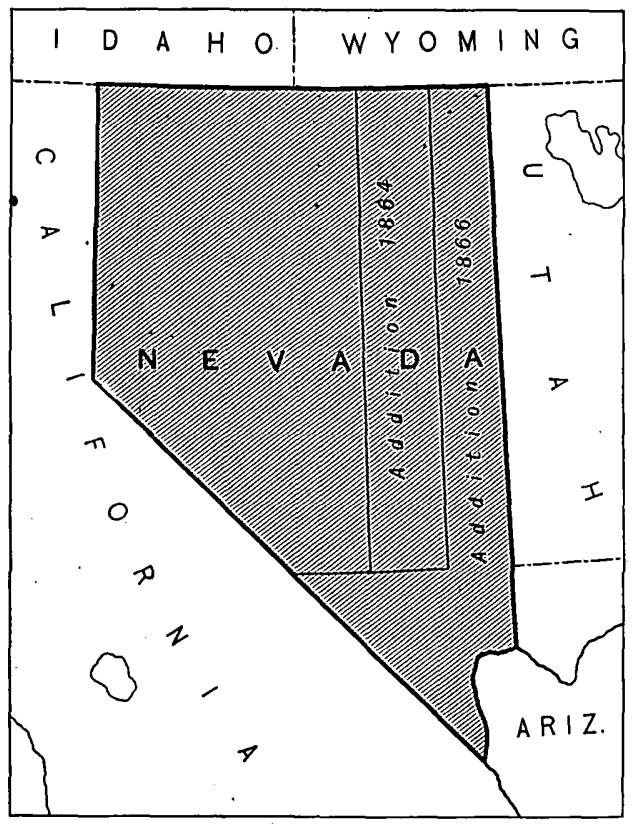

HISTORICAL DIAGRAM OF NEVADA. 
on this meridian to its intersection with the thirty-seventh parallel; anci eastward along the thirty-seventh parallel to the point of beginning.

NEVADA.

Nevada, as originally constituted on March 2, 1861, was formed from territory taken from Utah. Its western boundary was made to conform to the eastern boundary of California (vide California, p. 139); its northern boundary, was, as now, the forty-second parallel; the eastern was the meridian of $39^{\circ}$, and the southern the parallel of $37^{\circ}$. $\mathrm{By}$ the enabling act the eastern limit was extended to the thirtyeighth meridian. It was admitted as a State October 31, 1864, with above limits as modified by the enabling act, and in 1866 its eastern limits were still further extended to longitude $37^{\circ}$, and its southern line established as at present, the latter addition having been made from Arizona.

In the act organizing the Territory the boundaries are defined as follows:

Beginning at the point of intersection of the forty-second degree of north latitude with the thirty-ninth degree of longitude west from Washington; thence running south on the line of said thirty ninth degree of west longitude until it intersects the northern boundary line of the Territory of New Mcxico; thence due west to the dividing ridge separating the waters of Carson Valley. from those that flow into the Pacific; thence on said dividing ridge northwardly to the forty-first degree of nurth latitude; thence due north to the southern boundary of the State of Oregon; thence due east to the place of beginning. (Thirty-sixth Congress, second session.)

The following is the text of that portion of the enabling act relating to boundaries:

Src. 2. That the said State of Nevada shall consist of all the territory included within the following boundaries, to wit: Commencing at a point formed by the intersection of the thirty-eighth degree of longitude west from Washington with the thirty-seventh degree of north latitude; thence due west along said thirty-seventh degree of north latitude to the eastern boundary line of the State of California; thence in a northwesterly direction along the said eastern boundary line of the State of California to the forty-third degree of longitude west from Washington; thence north along said forty-third degree of west longitude and said eastern boundary line of the State of California to the forty-second degree of north latitude; thence due east along the said forty-second degree of north latitude to a point formed by its intersection with the aforesaid thirty-eighth degree of longitude west from Washington; thence due south down said thirty-eighth degree of west longitude to the place of beginning. (Thirty-eighth Congress, first session.)

The following act makes the addition to its area from Arizona referred to above:

AN ACT concerning the boundaries of the State of Nevada.

That, as provided for and consented to in the constitution of the State of Nevada, all that territory and tract of land adjoining the present eastern boundary of the State of Nevada, and lying between the thirty-seventh and the forty-second degrees of north latitude and west of the thirty-seventh degree of longitude west of Washington, is hereby added to and made a part of the State of Nevada. 
SEC. 2. That there is hereby added to and made a part of the State of Nevada all that extent of territory lying within the following boundaries, to wit: Commencing on the thirty-seventh degree of north latitude at the thirty-seventh degree of longitude west from Washington, and running thence south on said degree of longitude to the middle of the river Colorado of the West; thence down the middle of said river to the eastern boundary of the State of California; thence northwesterly along said boundary of California to the thirty-seventh degree of north latitude; and thence east along said degree of latitude to the point of beginning. (Thirty-ninth Congress, first session.)

The present limits of Nevada are as follows:

The east boundary is the thirty-seventh meridian of longitude, extending from the forty-second parallel of latitude southward to its intersection with the middle of the Colorado River; thence following the mid-channel of the Colorado River down to the point where it intersects the thirty-fifth parallel of latitude; the southwest boundary is the arc of a great circle running from the last-mentioned point and the point of intersection of the one hundred and twentieth degree of longitude west of Greenwich with the thirty-ninth parallel of latitude; the west boundary is the one hundred and twentieth degree of longitude west of Greenwich; the north boundary is the forty-second parallel of latitude.

The north boundary was surveyed and marked in 1873, and the west boundary, from latitude $42^{\circ}$ south to Lake Tahoe and thence southeast to Colorado River, in latitude $35^{\circ}$, in 1872 , under the General Land Office. Between 1890 and 1899 the United States Coast and Geodetic Survey, under an appropriation by Congress, ran a new line from Lake Tahoe to Colorado River, differing widely in some places from the former line.

\section{IDAHO.}

The Territory of Idaho was formed March 3, 1863, from parts of Washington, Dakota, and Nebraska. Its original limits, which included, besides the present territory, all of Montana and Wyoming, were given as follows in the act organizing the Territory:

That all that part of the territory of the United States included within the following limits, to wit: Beginning at a point in the middle channel of the Snake River where the northern boundary of Oregon intersects the same; then follow down said channel of Snake River to a point opposite the mouth of the Kooskooskia, or Clearwater River; thence due north to the forty-ninth parallel of iatitude; thence east along said parallel to the twenty-seventh degree of longitude west of Washington; thence south along said degree of longitude to the northern boundary of Colorado Territory; thence west along said boundary to the thirty-third degree of longitude west of Washington; thence north along said degree to the forty-second parallel of latitude; thence west along said parallel to the eastern boundary of the State of Oregon; thence north along said boundary to the place of beginning. (Thirtyseventh Congress; third session.)

From this were formed Montana in 1864 (vide Montana, p. 131) and Wyoming (vide Wyoming, p. 132) in 1868, thereby reducing this 
U. 8. GEOLOGICAL- SURVEY

BULLETIN NO. 226 PL. LIII

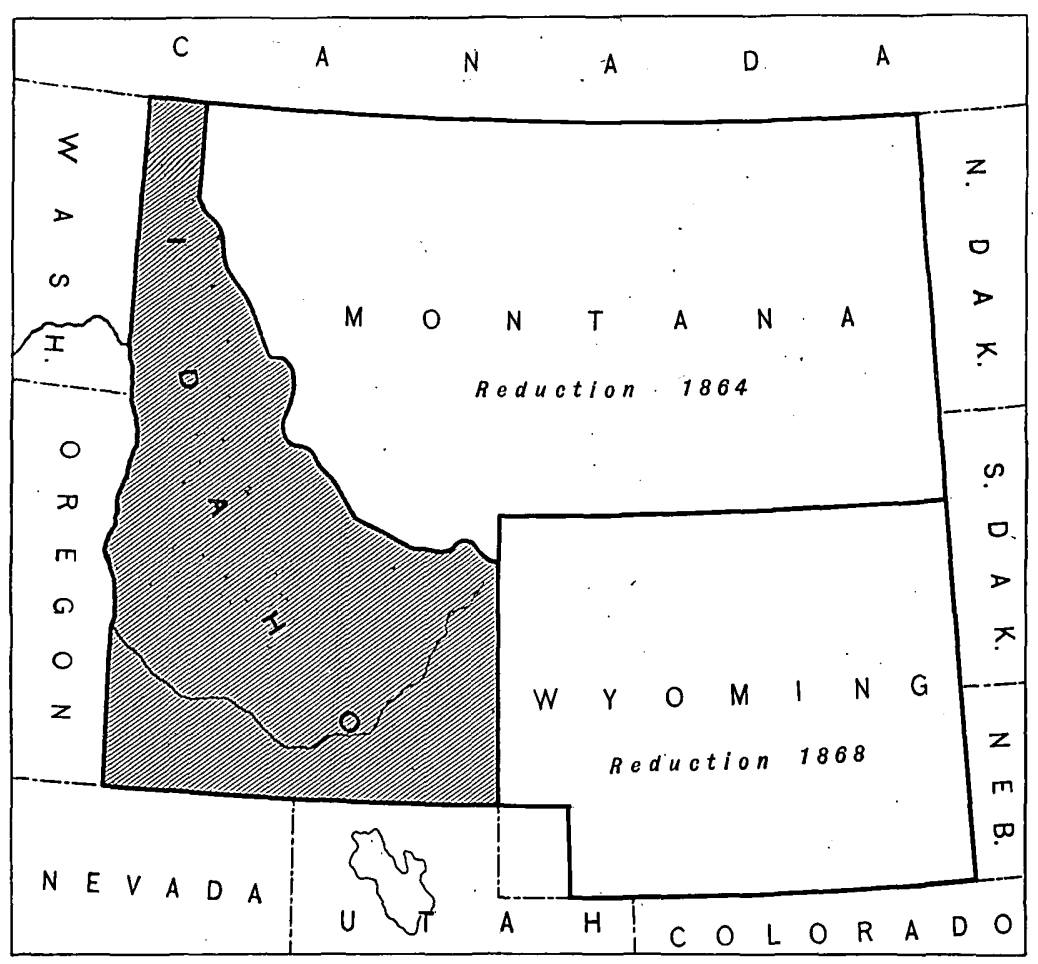

HISTORICAL DIAGRAM OF IDAHO. 
territory; with the small addition made in 1873 (vide Montana, p. 131), to its present limits.

- The present boundary line of Idaho is as follows: Beginning at the intersection of the thirty-ninth meridian with the boundary line between the United States and the British Possessions, jt follows said meridian south until it reaches the summit of the Bitter Root Moun-. tains; thence southeastward along the crest of the Bitter Root range and the continental divide until it intersects the meridian of thirtyfour degrees of longitude; thence southward on this meridian to the forty-second parallel of latitude; thence west on this parallel of latitude to its intersection with a meridian drawn through the mouth of the Owyhee River; north on this meridian to the mouth of the Owyhee River; thence down the mid-channel of the Snake River to the mouth of the Clearwater; and thence north on the meridian which passes through the mouth of the Clearwater to the boundary line between the United States and the British Possessions; and east on said boundary line to the place of beginning.

On July 3, 1890, Idaho was admitted as a State with the above limits.

The west boundary of Idaho, from the mouth of Clearwater River to the forty-ninth parallel, was surveyed and marked in 1873-74. The longitude of this line has been determined by the United States Geological Survey to be $117^{\circ} 02^{\prime} 34^{\prime \prime}$. The west boundary, from the mouth of Owyhee River south to the Nevada boundary, was surveyed and marked in 1867. Its longitude has been determined as $117^{\circ} 01^{\prime} 56^{\prime \prime}$ by the United States Geological Survey. Both these lines were run under the General Land Office.

\section{OREGON.}

Oregon Territory was organized August 14, 1848. The grounds of our title to its area are obscure. In treating with Great Britain for the establishment of our northern boundary west of the Rocky Mountains this region was claimed on three grounds - that of discovery and occupation, the Louisiana purchase, and cession from Spain. On which of these grounds we succeeded in having the boundary established on the forty-ninth parallel will never be ascertained, and is of little moment.

The Territory as originally established extended from the fortysecond to the forty-ninth parallel, and from the Pacific Ocean to the crest of the Rocky Mountains, with boundaries defined in the organizing act as follows:

All that part of the territory of the United States which lies west of the summit of the Rocky Mountains, north of the forty-second degree of north latitude, known as the Territory of Oregon, shall be organized into and constitute a temporary government by the name of the Territory of Oregon. (Thirtieth Congress, first session.)

In 1853 the Territory was reduced by the formation of Washington Territory (vide Washington, p. 138), and on February 14, 1859, it was 
admitted as a State with its present boundaries. These are defined below in an extract from the State constitution:

Beginning one marine league at sea due west from the point where the fortysecond parallel of north latitude intersects the same; thence northerly, at the same distance from the line of the coast lying west and opposite the State, including all islands within the jurisdiction of the United States, to a point due west and opposite the middle of the north ship channel of the Columbia River; thence easterly to and up the middle channel of said river, and where it is divided by islands, up the middle of the widest channel thereof, and in like manner up the middle of the main channel of Snake River to the mouth of the Owyhee River; thence due south to the parall ${ }^{\text {' }}$ of latitude forty-two degrees north; thence west along said parallel to the place beginning, including jurisdiction in civil and criminal cases upon the Columbia Riv: and Snake River concurrently with States and Territories of which those rivers form a boundary in common with this State. But the Congress of the United States, in providing for the admission of this State into the Union, may make the said northern boundary conform to the act.creating the Territory of Washington.

The boundary line between Oregon and Washington on the fortysixth parallel of latitude was surveyed and marked in 1864, under the General Land Office.

\section{WASHINGTON.}

This was organized March 2, 1853, from.a part of Oregon Territory. Its limits, as originally constituted, were as given in the following clause from the act of Congress creating it:

That from and after the passage of this act all that portion of Oregon Territory lying and being south of the forty-ninth degree of north latitude, and north of the middle of the main channel of the Columbia River from its mouth to where the forty-sixth degree of north latitude crosses said river, near Fort Walla Walla, thence with said forty-sixth degree of latitude to the summit of the Rocky Mountains, be organized into and constitute a temporary government by the name of the Territory of Washington. (Thirty-second Congress, second session.)

In 1859, on the formation of the State of Oregon, the residue of the Territory of Oregon, being the portion lying east of the present limits of the State, extending thence to the crest of the Rocky Mountains, was added to Washington. This area, with the part of Washington lying east of its present limits, was included in Idaho on the formation of that Territory in 1863.

The present boundaries of the State of Washington are as follows: Beginning on the coast at the mouth of the Columbia River; following up the main channel of the Columbia River to its point of intersection with the forty-sixth parallel of latitude; thence east on the forty-sixth parallel to the Snake River; thence down the main channel of the Snake River to the mouth of the Clearwater; thence north on the meridian which passes through the mouth of the Clearwater to the boundary line between the United States and the British Possessions; thence west with that boundary line to the Pacific.

Washington was admitted as a State on November 11, 1889, with its limits as above defined. 
U. S. GEOLOGICAL SURVEY

BULLETIN NO. 226 PL, LH

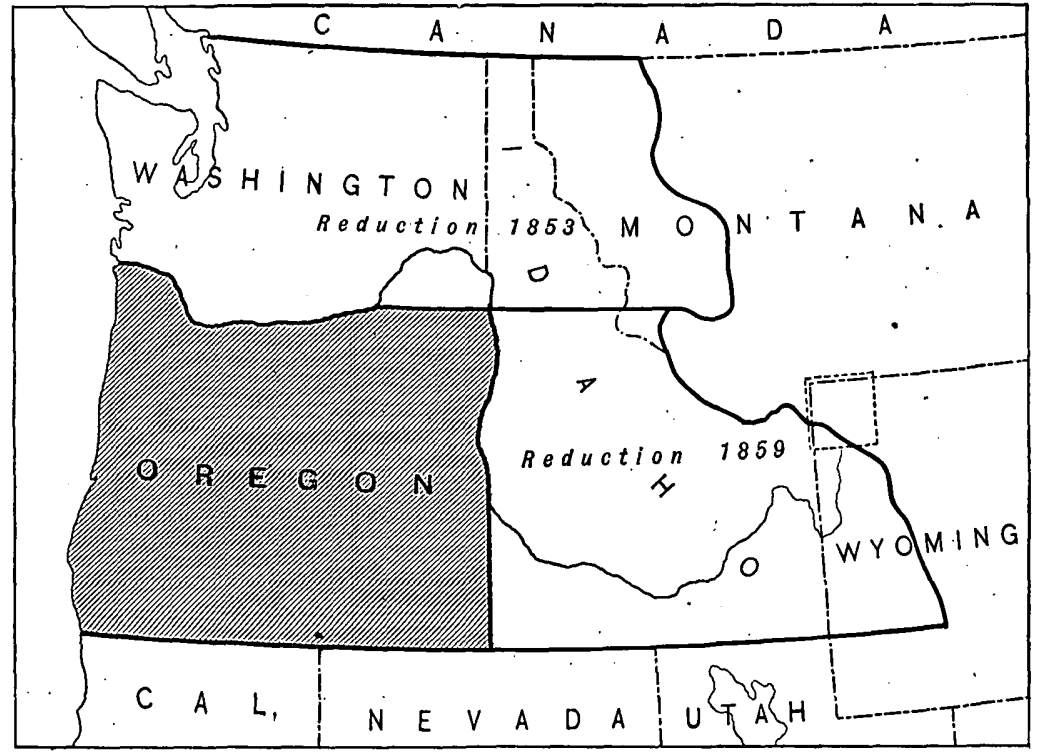

HISTORICAL DIAGRAM OF OREGON.

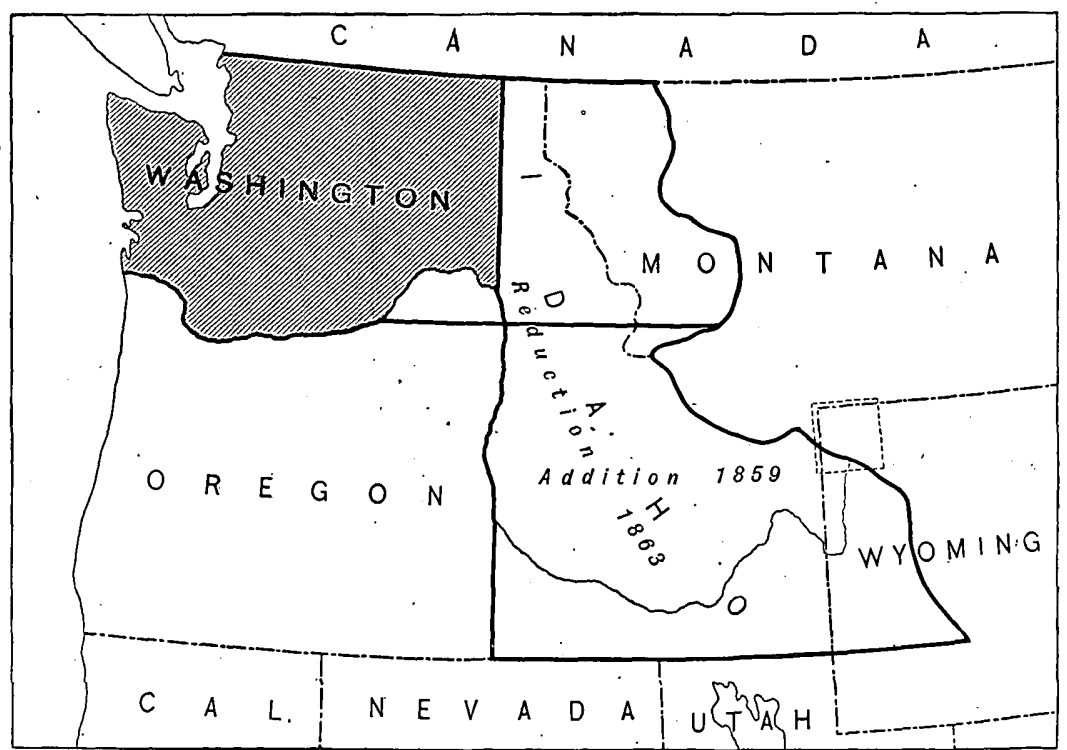

HISTORICAL DIAGRAM OF WASHINGTON.

Bull. 226-04-16 


\section{CALIFORNIA.}

California was admitted to the Union on September 9, 1850. Its area was taken from territory acquired from Mexico by the treaty of Guadelupe-Hidalgo. Its limits, as defined in the State constitution, are as follows:

Commencing at the point of intersection of forty-second degree of north latitude with the one hundred and twentieth degree of longitude west from Greenwich, and running south on the line of said one hundred and twentieth degree of west longitude until it intersects the thirty-ninth degree of north latitude; thence running in a straight line in a southeasterly direction to the river Colorado, at a point where it intersects the thirty-fifth degree of north latitude; thence down the middle of the channel of said river to the boundary line between the United States and Mexico as established by the treaty of May 30, 1848; thence running west and along said boundary line to the Pacific Ocean, and extending therein three English miles; thence running in a northwesterly direction and following the direction of the Pacific coast to the forty-second degree of north latitude; thence on the line of said fortysecond degree of north latitude to the place of beginning. Also all the islands, harbors, and bays along and adjacent to the Pacific coast.

The northern boundary was surveyed and marked in 1868-69, under the General Land Office. 



\section{N D E X.}

Acadia, charter of, area embraced by .... Page.

Alabama, State of, admission of .......... 10,36 State of, boundary between Florida and .................... 108-109

boundary between Georgia and.. 107 hetween Mississippi and .... 109-110

Territory of; formation and boundaries of 10,36

Alaska, boundarý between Canada and, agreement of Boundary Tribunal concerning.....

boundary between Canada and, map showing ....................

hetween Canada and, treaty provisions in regard to........ 25-26

purchase of, history of . . . . . . . . . . . . 25-28

Alexander, Robert, reference to.......... 116

Arizona, historical diagram of ........... 134

organization and boundaries of.. 38, 134-135

Arkansas; State of, admission of . . . . . . . . 36,114

State of, boundaries of ............. 113-115

historical diagram of............. 114

Territory of, organization and boundaries of ................... 36,113

Baltimore, Lord, grant to............... 89

Barr, —_, western boundary of Connecticut surreyed by ......

Beck, James B., reference to..............

Berkeley, Lord John, grant to............

Black, J. S., reference to ..................

Brooke, Lord, grant to.

Cagaram Jolo, purchage of

Calitornia, State of, admission and bound aries of . . . . . . . . . . . 37,139

Calvert, Philip, reference to..............

Canada, boundary between Alaska and, treaty provisions in regard to ........................ $25-20$

boundary between Alaska and, map showing

- boundary between Maine and, maps showing.

chusetts and ............... $65-69$ and, map showing......... 68

between New York and..... 71-72 73-76 map showing .................. 74

between Rhode Island and........ 71-72 map showing ................ 72

cessions by, to General Government. 36,76 claims of, in Territory Northwest of the River Ohio............. 33

grants and charters in ............... 72-73

Crozat, Antoine de, grant to ............ 19, 20

Culpeper, Lord, grant to ................. 99

Dakota, division of ..................... 129

organization and boundaries of .. $37,127,129$

See also North Dakota; South Dakota.

Delaware, boundary between Maryland and ....................... 88

boundary between New Jersey and .. $\quad 84$

between Pennsylvania and ...... $86^{\circ}$

grants and charters in ............... 87-88

Detroit River, boundary in, between United States and Canada, map showing .............. 16, 18

between United States and, in Niagara River, map showing .

in St. Clair and Detroit rivers, map showing

in St. Lawrence River, map showing

in St. Marys River, map showing ........................

Carr, Robert, appointed commissioner on controversies in the colo. nies

District of Columbia, acts of Congress relating to .............. 93-94

bounds of $\ldots 4$

lands ceded for . ...................... $92-93$

Disturnell's map, extract from, showing southwestern boundary... $\quad 16$

Dixon, Charles, work of ............... 86

Ellicott, Andrew, surreys by ......... 8\%, 105-1.06

Erie purchase, claims of States to........ 34

Fairfax, Lord, grants by................

Florida, State of, admission of ........... 108

State of, boundary between Alabama and ....................... 108-109 boundary between Georgia and. 106-107

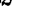

8

4

2

3

20

6


Florida, Territory of, cessions and retrocessions of lands in ...... organization of ..........................

Florida purchase, history of . . ........... 22-23 Floridas, boundary between United States and, treaty with Spain in regard to......... Gadsden purchase, history of............ Georgia, boundary between Alabama and

between South Carolina and . . . . 103-104

between Tennessee and .......... 106

cessions to General Government by .. 33 ,

36,105

grants and charters in ............. 104

historical diagram of ................. 104

Germany, arbitration by Emperor of .... 19

Ghent, treaty of, provisions of, in regard to boundary ............. 11-12

Gorges, Ferdinando, lands granted to.... 40,41.

Gould, Major, western boundary of Connecticut surveyed by ......

Graham, Lieutenant-Colonel, verification

by, of Mason and Dixon's $\operatorname{lin} \theta$

Graham, William A., reference to.....

Great Britain, treaties with . 9-10, 10-15, 16, 17-19

Guadalupe-Hidalgo, treaty of, territory added to United States by .................. 23-25

Guam, acquisition of ...................

Hapton, Lord, grant to .....................

Hawajian Islands, acquisition of ........

Hazen, Richard, survey $b_{y}$, of boundary between New Hampshire and Massachusetts .......

Idaho, State of, admission of ............

State of, boundaries of ..................... historical diagram of : . . ...........

Territory of, formation and boundaries of . .............. 35, 129, 130

Illinois, State of, admission of .......... 1120

State of, boundaries of .............. 120 historical diagram of........... 120

Territory of, formation and bound-

aries of .................. 120

Indian 'Territory, limits of ............. $\quad 3 i$

Oklahoma formed from . .......... 130

Indiana, State of, admission of . . . . . . . 35, 119

State of, boundaries of ............ 119-120

historical diagram of ........... 118

Territory of, organization and boundaries of . .............. 34-35, 119

Iowa, State of, admission of . . ........ 36, 125 State of, boundaries of ............. 125 historical diagram of ........... 124 Territory of, organization and boundaries of . . . . . . . . 36, 122, 124-125

Jenkins, Chaxles A., reference to ......... 91

Kansas, State of, admission of .......... 127

State of, boundaries of ........... $12 i$

historical diagram of . . .......... 126

Kansas, Territory of, formation and boundaries of . ....... $3 \pi, 120-12 \pi$
Page.

Kentucky, State of, admission of ...... 117

boundaries of ...................... 117

boundary between Tennessee and, map of ................. 116

between Virginia and . . . . . . . . . . $97-98$

map showing ................ 96

Kerr, Professor; quoted on north and south boundary lines of North Carolina.......... 101-102

London, treaty of, provisions of, in regard to boundaries...... 10-11

Louisiana, ancient limits of, as understood by France. ......... 19-20

cession and retrocessions of ........ 20-21

State of, additions to ............... 112

admission of ................. 36,111

historical diagram of . . . . . . . . 112

original boundaries of .......... 111

Territory of, formation of ............ 36 name of, changed to Missouri Territory ................... 111

Louisiana puichase, history of . . . ... . ... 19-22

States and Territories formed from. - 36-37

Maine, admission of, as a State......... 70

boundaries of . . . . . . . . . . . . $39-47$

boundary between Canada and, maps showing ................. 16,18

between Canada and, settlement of ....................... 15 18

between New Hampshire and, map showing ............. 18

resurvey of ................... $45-47$

settlement of ................. 4t-44

Marbois, Barbé, cited on limits of Louisiana . ................ 21,22

Maryland, boundary between Pennsylvania and ............... 86-8i boundary between Virginia and ..... 89-92 cession of land by, for seat of govern: ment ..................... 92

grants and charters in .............. $\quad 89$ Mason and Dixon's line, survey of ....... 86-87 Mason, Jeremiah, work of .............. 86 Mason, John, lands granted to . . . . . ... 40, 4i-48 Massachusetts, boundary between Connecticut and . . . .......... 65-69

boundary between Connecticut and, map showing ............. 68

between New Hampshire and .... 48-50

between New York and.......... 69-71

between Rhode Island and . . . . . . . 55-65 map showing ................ 60

between Vermont and ........... 52

of, on the north, maps showing - . 54 cession of land to New York by...... 70 cessions of land to General Government by . . ............... 31-32,70

claims of, in Territory Northwest of the River Ohio............ . 33,34

grants and charter's in ............... 54-55 Maverick, Samuel, appointed conimissioner on controversies in the colonies. ..............

Mexico, boundary between United States and, treaty provisions in regard to............ 23-24,25 
Page.

Mexico, territory acquired from ......... 23-25 - territory acquired from. States and Territories formed from . . $36-3 \%$

Michigan, State of, admission of ........ 35,121 State of, boundaries of ............. 121-122 boundary between Canada and, through St. Marys River. map showing

historical diagram of

Territory of, formation and boundaries of ........... 35, 119, 120-121

Micłller, N., reference to................. 91

Minnesota, State of, admission of . . .... 36,126 State of, boundaries of .............. 126

historical diagram of ............ 124

Territory of, formation and boundaries of ............ 35,36,125-120

Mississippi, State of, admission of . . . . .... 36, 110

State of, boundary between Alabama and ................. 109,110

boundary between Tennessee and ..................... 110-111

historical diagram of ............. 104 Territory of, formation and boundaries of . .............. $35,109,110$

Missouri, State of, admission of........ 36, 123

State of, boundaries of ............. 123-124

historical diagram of ............ 122

Territory of, formation and boundaries of . .............. $36,111,123$

Mitchel, survey by, of boundary between New Hampshire and Massachusetts

Munsell, Luke, reference to ...............

Montana, State of, admission of .......... 132

State of, boundaries of . ............. 131-132

Territory of, formation and boundaries of.

38,131

Monts, Sieur de, grant to................ 39

Nebraska, State of, admission of......... 127

State of, boundaries of ............. 127-128

historical diagram of . ............ 126

Territory of, formation and boundaries of $3 \tilde{i}, 1 \%$

Netherlands, arbitration by the King of. 16-17

Nevada, State of, admission of ......... 135

State of, boundaries of .............. 136

historical diagram of ........... 134

Territory of, formation and boundaries of . . . ......... $3 i-38,135-136$

New Hampshire, boundary between Canada and

boundary between Canada and, map showing.

(18

between Maineand, map showing. resurvey of ................... $45-47$ settlement of .................. $41-44$

between Massachusetts and ...... 48-50

between Vermont and ........... 52

cbar ter's and land grants in.......... 47-48 controversy between New York and, concerning boundary ..... 50-51

New Jersey, boundary between Delaware and.

84

boundary between Pennsylvania and. 84-85 between New York and.......... $79-81$.
New Jersey, bouncary of map showing grants and charters in ............ 83-84 sale of, by Duke of York............. $\quad 78$

New Mexico, formation and boundaries of . . .

historical diagram of ............... 132

New York, boundaries, western and southern, of, map showing

boundary between Canada and, in Niagara River, map showing .......................

between Canada and, in St. Lawrence River, map showing

10

between Connecticut and. ........ $73-76$

map showing ................. 74

between Massachusetts and. . ..... 69-71.

between New Jersey and .... . . .... 79-81

between Pennsylvania and . . . ..... 81-83

between Vermont and ............ 52,53

map showing ................ 52

cessions to General Government by .. 31, 78

to various States by . . . ............

changes in territory of ............. 78

controversy between New Hampshiré and, concerning boundary ................ $50-51$

grants and charters in ............... $77-78$

historical diagram of ................. 78

Niagara River, boundary in, between New York and Canada. map showing . ..............

Nichols, Richard; appointed coumissioner on controversies in the colonies $\because$

North Carolina, boundary between Georgia and ...............

boundary between South Carolina and................. 100-101, 102

between Tennessee and ......... 102-103 map of . .................. 102 between Virginia and. ...... 100,101-102 between Virginia, Tennessee, and, map of .................. 98

cessions to General Government by - ................. 3?-33, 35,98

grants and charters in .............. 99-100

North Dakota, State of, admission of .... $\quad 129$

State of, boundaries of ............. 129

historical diagram of ............ 128

Ohio, admission of . . . . . . . . . . . . . 33, 117, 118

boundaities of . ....................... 117-119

historical diagram of ................. 1.1.4

Ohio River, territory northwest of. See Territory Northwest of River Ohio.

Oklahoma Territory, formation and boundaries of ............. 130

historical diagram of .............. 128

Oregon, State of, admission of ........ 37, 13i -138

Oregon, State of, botindaries of ......... 138

historical diagram of ............. 138

Territory of, formation and boundaries of . ................. 37,137

Orleans, Territory of, admitted as State of Louisiana . .............. 
Orleans, Territory of, organization and 'Prge. boundaries of . . ........... 36,111

Paris, treaty of, territory relinquished by -.............................

Pemaquid, annexation of, to New England . . .............. 41,54,78

Penn, William, charter's granted by ..... 88 grant to, of Province of Pennsylvania ................... 85,87 territory purchased by ............. 78,85

Pennsylvania, boundary between Delaware and................. 86

boundary between Maryland and.... 86-87 between New Jersey and ......... 84-85 between New York and. .......... 81-83 grants and charters in .............. 85

Peters, Doctor, latitude and longitude determinations by ...........

Philippine Islands, acquisition of. . 82
$28-29$

Plymouth Company, charter of, extract from, defining boundaries of Maine .............................

grants to and by .................. 39,72

Popham, George, colony founded by .....

Porto Rico, acquisition of..................

Providence Plantation, charter of, extract from . ................

patent to, extracts from ..............

Rhode Island, boundary between Connecticut and .............. 71-72

boundary between Massachusetts and

$55-65$

between Massachusetts and, controversy concerning ...... 5 $6-65$

map showing ................. 60

grants and charters in .............. 71

Rhode Island and Providence Plantations, charter to. 71

Saffrey, Solomon, reference to . . ........ 55,56

St. Clair River, boundary in, between United States and Canada, map showing .............

St. Lawrence River, boundary in, between New York and Canada, map showing.........

St. Marys River, boundary in, between Michigan and Canada, map

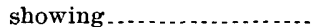

Saltonstall, Richard, grant to . ......... Say and Seal, Lord, grant to ............. Scarbrugh, Edmurd, reference to........ Selleck, _ western boundary of Connecticut surveyed by .....

South Carolina, boundary between Georgia and

boundary between North Carolina and . ............... 100-101, 102

cessions to General Goverument by ... 32,

grants and charters in

$35-36$

South Dakota, admission of ............ 129

historical diagram of . ............... 128

Spain, treaty with, ceding Floridas to the United States..............

treaty with, ceding Porto Rico, Guam, and the Philippines.
Spain, treaty with, provisions of, relating to boundary between United States and the Floridas. .......................

Stirling, Earl of, grant to............... 39-40 Swedish 'West India Company, settlement

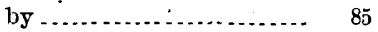

Tennessee, admission of ............. 36

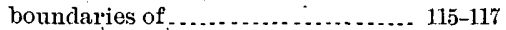

boundary between Georgia and ...... 106

between Kentucky and, map of .. 116

between North Carolina and ... 102-108 map of . .................... 102

between Virginia and. ........... 98

between Virginia, North Carolina, and, map of ............ 98

Territory Northwest of the River Ohio, area and boundaries of.... 33

claims of Connecticut in ............ 33

claims of Massachusetts in.......... $\quad 33$

claims of Virginia in ................. 33

provisional government of, bill for... , 33

States formed from . . . . . . . . . . . . . . . . 34-35

Territory South of River Ohio, boundaries of ................... 35

Texas, admission of ................ $36-37,112$

boundaries of . . . . . . . . . . . . . . . 23, 112-113

boundary between New Mexico and. 113

historical diagram of............... 112

land sold to General Government by - 112

Tutuila, acquisition of ................. 29

United States, accessions to territory of. 19-29 accessions to territory of, map showing $\quad \$ 0$

boundaries of . ..................... 9-19

boundary between Canada and, history of settlement of . . .... 10-19

between Canada and, in Niagara River, map showing.......

in St. Clair and Detroit rivers, map showing ..............

in St. Lawrence River, map showing.

in St Margs River map show. ing

Ushur, John, province of from ...................... and $\mathrm{by}$-...

Utaln, State of, adm

tah, State of, admission of ............ 134

State of, boundaries of . ............ 134

historical diagram of ........... 132

Territory of, formation and boundaries of . ............. 37, 133-134

Vermont, admission of ............... 52

boundary between Canada and...... $\quad 52$

between Massachusetts and ..... $\quad 52$

between New Hampshire and .... 52

between New York and.......... 52,53

map showing ............... 52

land ceded to New York by .........

grants and charters in . ............. 51-52 
Virginia, boundary between Kentucky and, map showing. boundary between Maryland and. between North Carolina and $89-92$ 100 , 101-102 between North Carolina, Tennessee, and, map of bétween Tennessee and

between West Virginia and map showing

changes in territory of ................ claims of, in Territory Northwest of the River Ohio. 33,34

division of first charter of, boundaries described in.

lands granted under. grants and charters in

historical diagram of iand ceded to General Government by ..................... 31,93

- land ceded to various States by ...... 95,96 land retroceded to, by General Government

second charter of, boundaries described in ter of, extract from

third charter of, extract from ....... western boundary of
Warwick, Earl of, grant to.............. $\cdot \gamma_{2}$

Washington, State of, admission of ...... 138 State of, boundaries of ............... 138

historical diagram of ............ 138

Territory of, formation and boundaries of ................... 37,138

Webster-Ashburton treaty, provisions of, in regard to northern boundary west of Rocky Mountains ................ 18-19

Webster, Daniel, reference to ........... 55

West Virginia, boundary between Mary: land and ................. 92

boundary bstween Virginia and ...... 98-99 between Virginia and, map show. ing ........................ 94

Williams, Roger, settlement by ......... 71

Wisconsin, State of; admission of . . ..... $35,1 \% 3$

Stat 3 of, boundaries of . . ........... 1222-123 historical diagram of ............. 120

Territory of, formation and bound 2 ries of . ............... $55,121,122$ Woodward, Nathaniel, reference to . .... 55,56 Wyoming, State of, admission of ......... 132 State of, boundaries of .............. 132 Territory of, formation and boundaries of . . . . . . . .

98 York, Dukè of, grants to...... 40-41,51,73,77,78 



\title{
PUBLICATIONS OF UNITED STATES. GEOLOGICAL SURVEY.
}

\author{
[Bulletin No. 226.]
}

The publications of the United States Geological Survey consist of (1) Annual Reports, (2) Monographs, (3) Professional Papers, (4) Bulletins, (5) Mineral Resources, (6) Water-Supply and Irrigation Papers, (7) Topographic Atlas of United States-folios: and separate sheets thereof, (8) Geologic Atlas of United States-folios thereof. The classes numbered 2,7 , and 8 are sold at cost of publication; the others are distributed free. A circular giving complete lists may be had on application.

The Professional Papers, Bulletins, and Water-Supply Papers treat of a variety of subjects, and the total number" issued is large. They have therefore been classified into the following series: A, Economic geology; B, Descriptive geology; C, Systematic geology and paleontology: D, Petrography and mineralogy; E, Chemistry and physics; F, Geography; G, Miscellaneous; H, Forestry; I, Irrigation; J, Water storage; K, Pumping water; L, Quality of water; M, General hydrographic investigations; N, Water power; O, Underground waters; P, Hydrographic progress reports. This bulletin is the thirty-seventh in Series F, the complete list of which follows (all are bulletins thus far):

\section{SERIES F, GEOGRAPHY.}

5. Dictionary of altitudes in United States, by Henry Gannett. 1884. 325^ pp. (Out of stock; see Bulletin 160.)

6. Elevations in Dominion of Canada, by'J. W. Spencer. $1884.43 \mathrm{pp.} \mathrm{(Out} \mathrm{of} \mathrm{stock.)}$

13. Boundaries of United States and of the several States and Territories, with historical sketch of territorial changes, by Henry Gannett. .1885. $135 \mathrm{pp}$. (Out of stock; see Bulletin 171.)

48. On form and position of sea level, by R. S. Woodward. 1888. 88 pp. (Out of stock.)

49. Latitudes and longitudes of certain points in Missouri, Kansas, and New Mexico, by R. S. Woodward. $1889.133 \mathrm{pp}$.

50. Formulas and tables to facilitate the construction and use of maps, by R. S. Woodward. 1889. $124 \mathrm{pp}$. (Out of stock.)

70. Report on astronomical work of 1889 and 1890 , by R. S. Woodward. $1890.79 \mathrm{pp}$.

72. Altitudes between Lake Superior and Rocky Mountains, by Warren Upham. 1891. 229 pp.

76. Dictionary of altitudes in United States (second edition), by Henry Gannett. 1891. 393 pp. (Out of stock; see Bulletin 160.)

115. Geographic dictionary of Rhode Island, by Henry Gannett. 1894. 31 pp.

116. Geographic dictionary of Massachusetts, by Henry Gannett. 1894 . $126 \mathrm{pp}$.

117. Geographic dictionary of Connecticut, by Henry Gannett. 1894. $67 \mathrm{pp}$.

118. Geographic dictionary of New Jersey, by Henry Gannett. 1894. $131 \mathrm{pp}$.

122. Results of primary triangulation, by Henry Gannett. $1894.412 \mathrm{pp}$., 17 pls. (Out of stock.)

123. Dictionary of geographic positions, by Henry Gannett. $1895 . \quad 183$ pp., 1 map. (Out of stock.)

154. Gazetteer of Kansas, by Henry Gannett. 1898. 246 pp., 6 pls.

160. Dictionary of altitudes in United States (third edition), by Henry Gannetr. 1899. 775 pp. (Out of stock.)

166. Gazetteer of Utah, by Henry Gannett. 1900.43 pp., 1 map.

169. Altitudes in Alaska, by Henry Gannett. $1900.13 \mathrm{pp}$.

170. Survey of boundary line between Idaho and Montana from international boundary to crest of Bitterroot Mountains, by R.U. Goode. 1900. 67 pp., 14 pls.

171. Boundaries of United States and of the several States and Territories, with outline of history of all important changes of territory (second edition), by Henry Gannett. 2900. 142 pp., 53 pls. (Out of stock.)

174. Survey of northwestern boundary of United States, 1857-1861, by Marcus Baker. 1900. 78 pp., 1 pl. .

175. Triangulation and spirit leveling in Indian Territorg, by C. H. Fitch. 1900. 141 pp., 1 pl.

181. Results of primary triangulation and primary traverse, fiscal year 1900-01, by $H$. M. Wilson, J. H. Renshawe, E. M. Douglas, and R. U. Goode. 1901. 240 pp., 1 map.

183. Gazetteer of Porto Rico, by Henry Gannett. 1901. $51 \mathrm{pp}$. 
185. Results of spirit leveling, fiscal year 1900-01, by H. M. Wilson, J. H. Renshawe, E. M. Douglas, and R. U. Goode. 1901. 219 pp.

187. Geographic dictionary of Alaska, by Marcus Baker. 1901. $446 \mathrm{pp.} \mathrm{(Out} \mathrm{of} \mathrm{stock.).}$

190. Gazetteer of Texas, by Henry Gannett. 1902. $162 \mathrm{pp} ., 8 \mathrm{pls.}$ (Out of stock.)

192 Gazetteer of Cuba, by Henry Gannett. 1902. 113 pp., 8 pls. (Out of stock.)

194. Northwest boundary of Texas, by Marcus Baker. 1902.51 pp., 1 pl.

196. Topographic development of the Klamath Mountains, by J. S. Diller. $1902.69 \mathrm{pp} .13 \mathrm{pls.}$

197. The origin of certain place names in the United States, by Henry Gannett. 1902. $280 \mathrm{pp}$. (Out of stock.)

201. Results of primary triangulation and primary traverse, fiscal year 1901-02, by H. M. Wilson, J. H. Renshawe, E. M. Douglas, and R. U. Goode. 1902. $164 \mathrm{pp} ., 1 \mathrm{pl}$.

214. Geographic tables and formulas, compiled by S. S. Gannett. $1908.284 \mathrm{pp}$.

216. Results of primary triangulation and primaíy traverse, fiscal year $1902-03$, by S. S. Gannett. 1908. $222 \mathrm{pp} ., 1 \mathrm{pl}$.

224. Gazetteer of Texas (second edition), by Henry Gannett. 1904. 177 pp., 7 pls.

B 226. Boundaries of the United States and of the several States and Territories, with an outlineof the history of all important changes of territory (third edition), by Henry Cannett. 1904: 145 pp., 54 pls.

Correspondence should be addressed to

The DIRECTOR,

United States Geological Survey,

MAY, 1904.

Washington, D. C. 


\section{LIBRARY CATALOGUE SLIPS.}

[Mount each slip upon a separate card, placing the subject at the top of the second slip. The name of the series should not be repeated on the series card, but the additional numbers should be added, as received, to the first entry.]

\section{Gannett, Henry.}

. . . Boundaries of the United States and of the sev$\dot{s}$ eral states and territories, with an outline of the history of all important changes of territory, 3d ed., by Henry Gannett. Washington, Gov't print. off., I9o4.

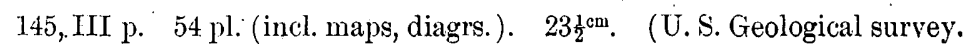
Bulletin no. 226.)

Subject series $F$, Geography, 37 .

First ed. 1885.

\section{Gannett, Henry.}

. . Boundaries of the United States and of the sev-

eral states and territories, with an outline of the history of all important changes of territory, 3d ed., by Henry. Gannett. Washington, Goṿ't print. off., I904.

145, III p. $54 \mathrm{pl}$. (incl. maps, diagrs.). $23 \frac{1}{2} \mathrm{~cm}$. (U. S. Geological survey. Bulletin no. 226.)

Subject series F, Geography, 37.

First ed. 1885.

\section{U. S. Geological survey.}

Bulletins.

no. 226. Gannett, Henry. Boundaries of the United States and of the several states and territories. ... 3d ed. 1904 .

\footnotetext{
U. S. Dept. of the Interior. see also

U. S. Geological survey.
} 